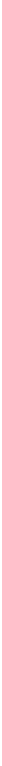

\title{
Centimeter
}

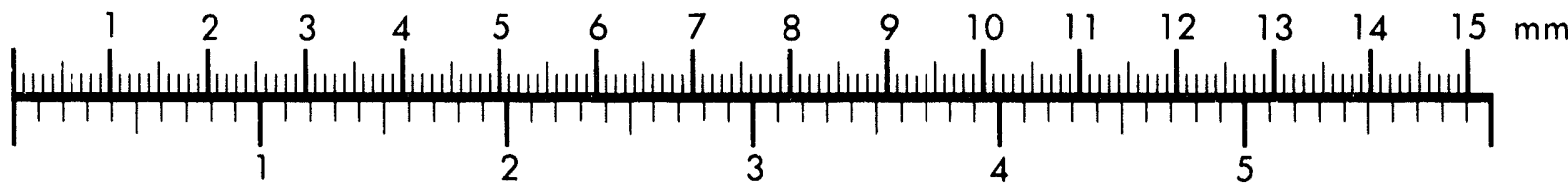
Inches
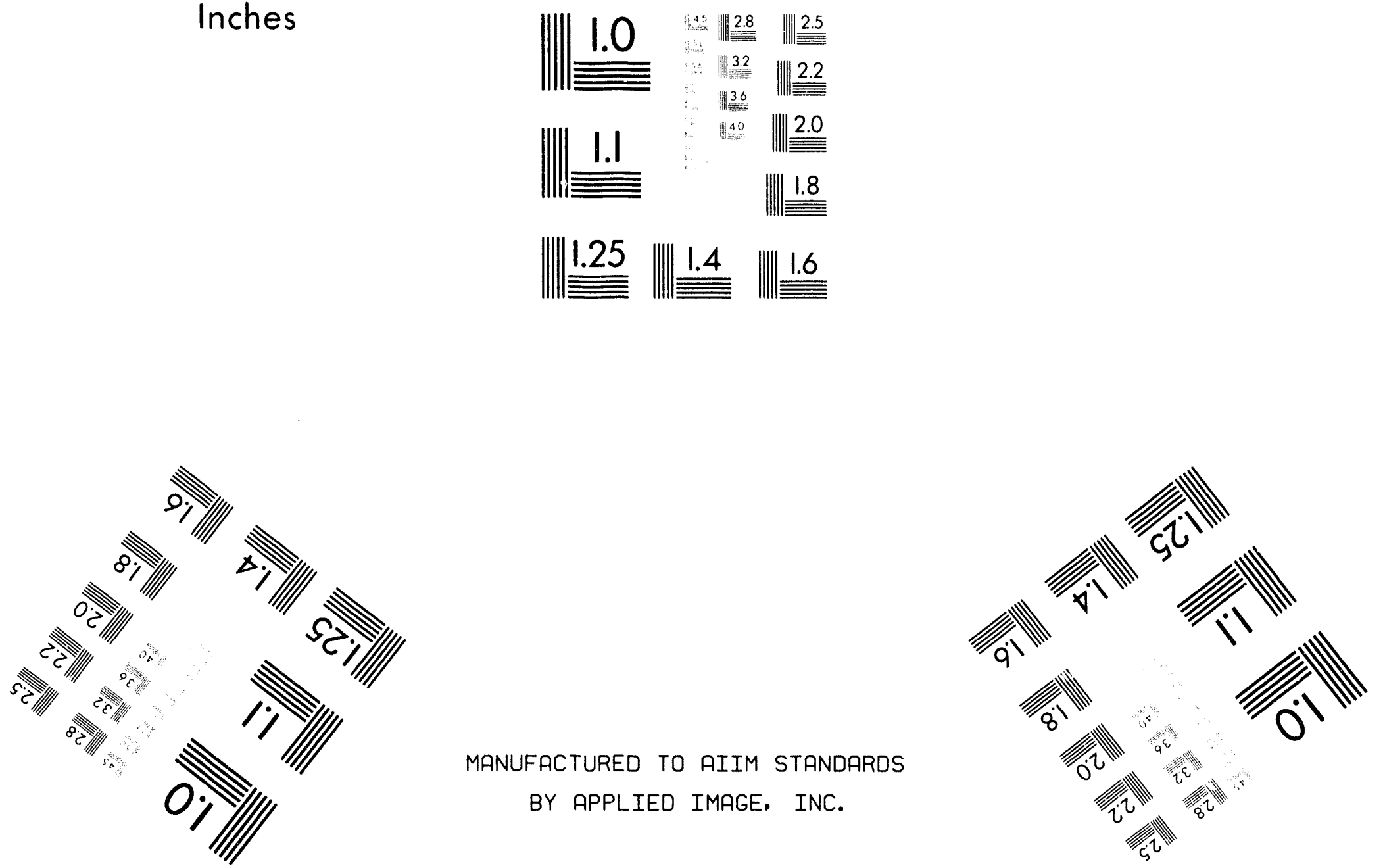

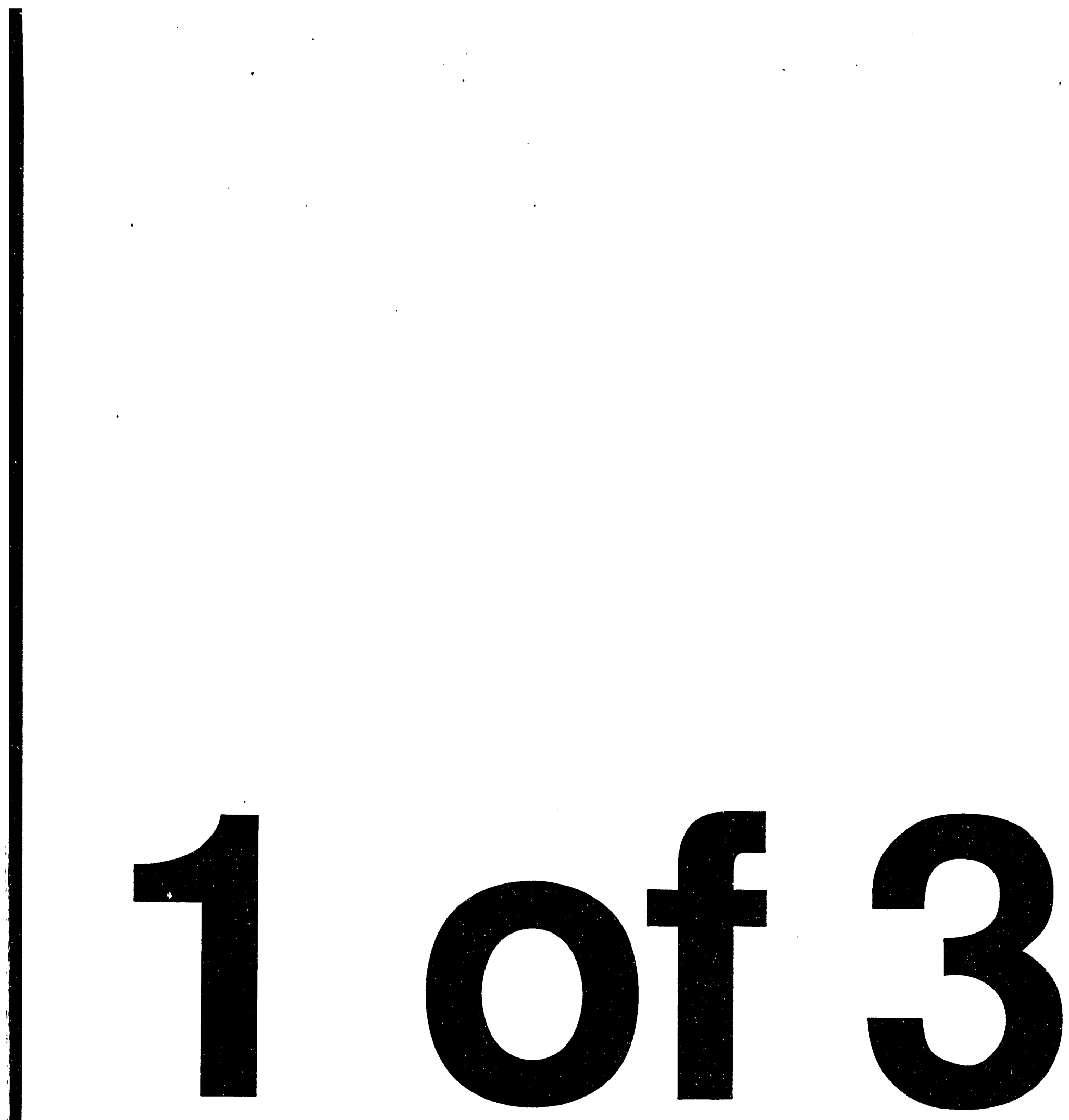


\title{
DISCLAIMER
}

This report was prepared as an account of work sponsored by an agency of the United States Government. Neither the United States Government nor any agency thereof, nor any of their employees, makes any warranty, express or implied, or assumes any legal liability or responsibility for the accuracy, completeness, or usefulness of any information, apparatus, product, or process disclosed, or represents that its use would not infringe privately owned rights. Reference herein to any specific commercial product, process, or service by trade name, trademark, manufacturer, or otherwise does not necessarily constitute or imply its endorsement, recommendation, or favoring by the United States Government or any agency thereof. The views and opinions of authors expressed herein do not necessarily state or reflect those of the United States Government or any agency thereof.

\section{Waste Management Facilities Cost Information Report for Greater-Than-Class C and DOE Equivalent Special Case Waste}

\author{
Fred Feizollahi \\ David Shropshire
}

Published July 1993

\section{Idaho National Engineering Laboratory EG\&G Idaho, Inc. Idaho Falls, Idaho $\mathbf{8 3 4 1 5}$}

\author{
Prepared for the \\ U.S. Department of Energy \\ Assistant Secretary for Environmental Restoration and Waste Management \\ Under DOE Idaho Operations Office \\ Contract DE-AC07-761D01570


Waste Management Facilities Cost Information Report

for Greater-Than-Class C and DOE Equivalent Special Case Waste

Prepared by:
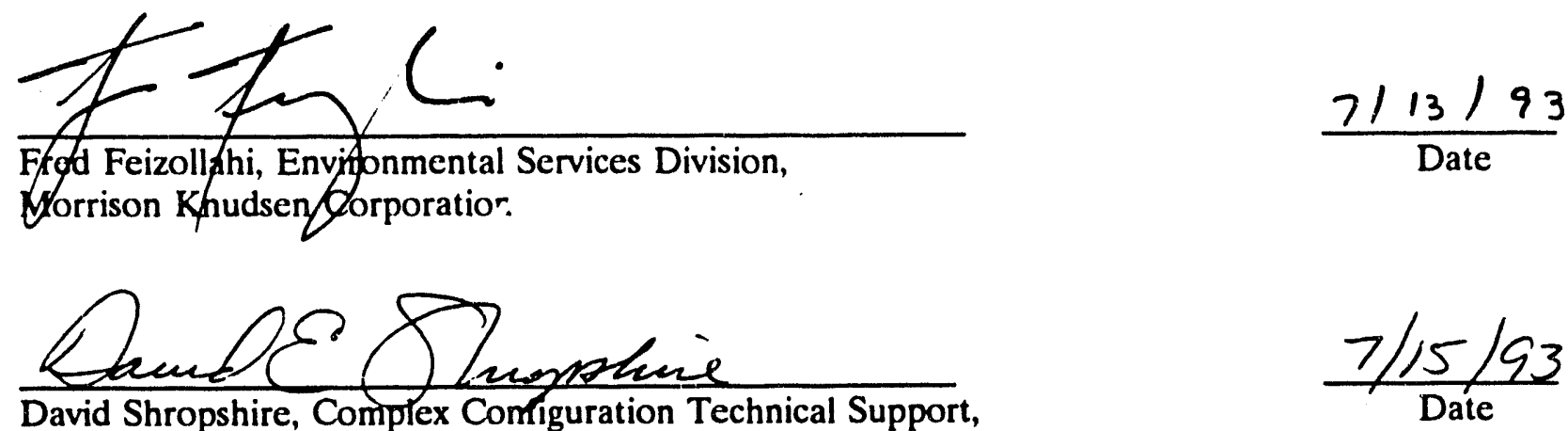

EG\&G Idaho, Inc.

Reviewed by:

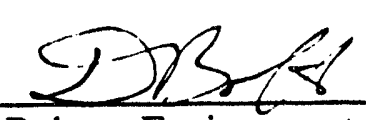

Derek Bolton, Environmental Services Division, Morrison Knudsen Corporation

Reviewed and Approved by:

Eric Williams, Manager Radioactive Waste Technology Support, EG\&G Idaho, Inc.

$$
\frac{7-13-93}{\text { Date }}
$$

$$
\frac{7-15-93}{\text { Date }}
$$




\section{ABSTRACT}

This Waste Management Facility Cost Information (WMFCI) report for Greater-Than-Class C low-level waste (GTCC LLW) and DOE equivalent special case waste contains preconceptual designs and planning level life-cycle cost (PLCC) estimates for treatment, storage, and disposal facilities needed for management of GTCC LLW and DOE equivalent waste. The report contains information on 16 facilities (referred to as cost modules). These facilities are treatment facility front-end and back-end support functions (administration support, and receiving, preparation, and shipping cost modules); seven treatment concepts (incineration, metal melting, shredding/compaction, solidification, vitrification, metal sizing and decontamination, and wet/air oxidation cost modules); two storage concepts (enclosed vault and silo); disposal facility front-end functions (disposal receiving and inspection cost mudule); and four disposal concepts (shallow-land, engineered shallow-land, intermediate depth, and deep geological cost modules). Data in this report allow the user to develop PLCC estimates for various waste management options. A procedure to guide the U.S. Department of Energy (DOE) and its contractor personnel in the use of estimating data is also included in this report. 


\section{PREFACE}

For ease of application, facility description and PLCC estimates related to some of the modules contained in previous Waste Management Cost Information reports (EGG-WTD-10443 and EGG-WM-10708) are repeated herein. The reader should note that when repeating previous modules, they have been either resized for adoption to GTCC and DOE equivalent waste or updated to incorporate the latest cost data. 


\section{ACKNOWLEDGEMENTS}

The authors would like to acknowledge the efforts of the technical contributors to this report: Richard Barlow, David Bean, David Burtun, Narayanan Doraswamy, Lisa Penaska, Bruce Stevens, Ben Teheranian, and Mark Waldman of Environmental Services Division, Morrison Knudsen Corporation; Technical Editors: Ed May of EG\&G Idaho, Inc. and Carolyn Ricketts of Morrison Knudsen Corporation. 


\section{CONTENTS}

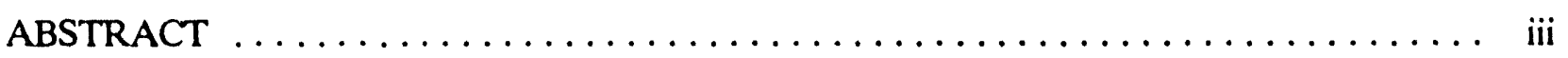

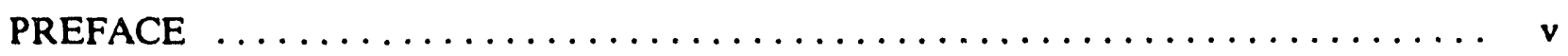

ACKNOWLEDGEMENTS $\ldots \ldots \ldots \ldots \ldots \ldots \ldots \ldots \ldots \ldots \ldots \ldots \ldots \ldots \ldots \ldots \ldots$ vii

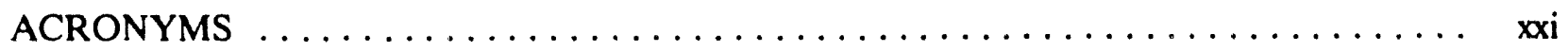

1. INTRODUCTION AND SUMMARY $\ldots \ldots \ldots \ldots \ldots \ldots \ldots \ldots \ldots \ldots \ldots$

$1.1 \quad$ Background $\ldots \ldots \ldots \ldots \ldots \ldots \ldots \ldots \ldots \ldots \ldots \ldots \ldots \ldots \ldots \ldots \ldots \ldots, 1$

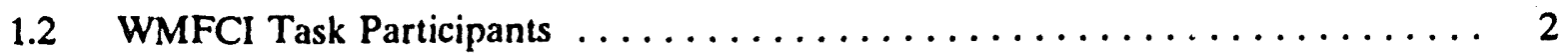

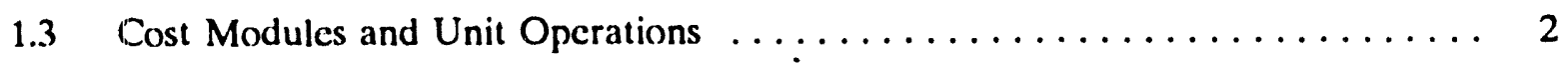

1.4 Facility Cost Estimating Methodology $\ldots \ldots \ldots \ldots \ldots \ldots \ldots \ldots \ldots \ldots \ldots$

1.4.1 Facility Operation Assumption $\ldots \ldots \ldots \ldots \ldots \ldots \ldots \ldots \ldots \ldots \ldots$

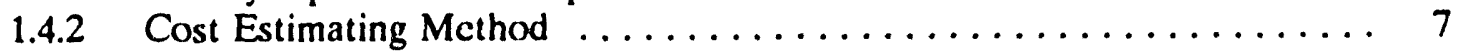

1.5 Waste Management Scenario Costing Procedure $\ldots \ldots \ldots \ldots \ldots \ldots \ldots . \quad 8$

1.6 Cost Assessment Activities . . . . . . . . . . . . . . . . . . . 9

1.7 Report Organization $\ldots \ldots \ldots \ldots \ldots \ldots \ldots \ldots \ldots \ldots \ldots \ldots \ldots . \ldots \ldots$

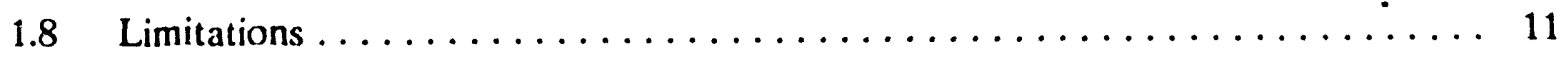

2. ADMINISTRATION SUPPORT FACILITY (COST MODULE LL) $\ldots \ldots \ldots \ldots 12$

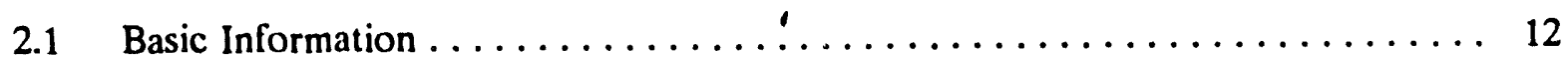

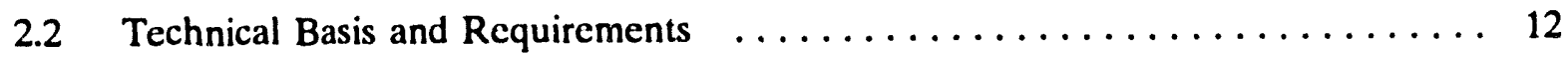

2.2.1 Functional and Operation Description $\ldots \ldots \ldots \ldots \ldots \ldots \ldots \ldots, 12$

2.2.2 Facility Integration $\ldots \ldots \ldots \ldots \ldots \ldots \ldots \ldots \ldots \ldots \ldots \ldots \ldots \ldots \ldots \ldots \ldots, 12$

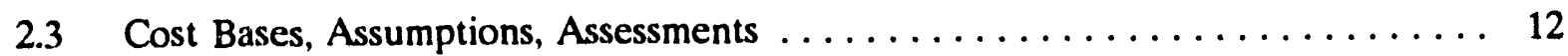

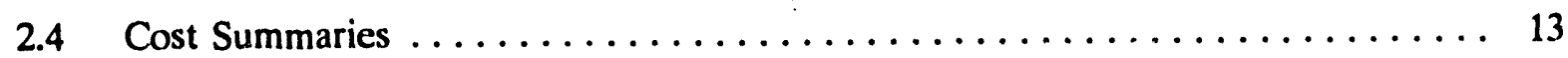

3. TREATMENT RECEIVING, PREPARATION, AND SHIPPING FACILITY

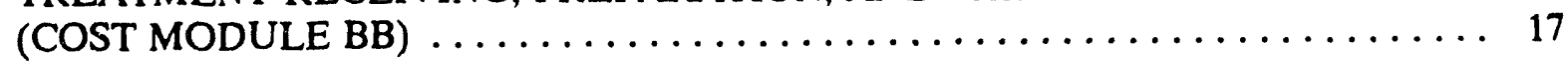

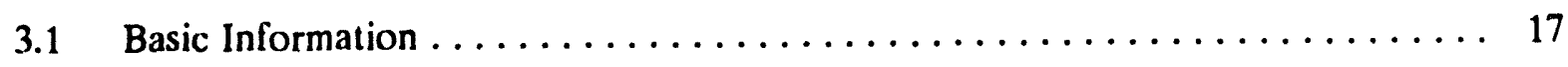




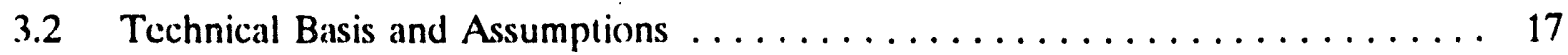

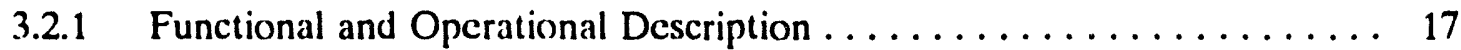

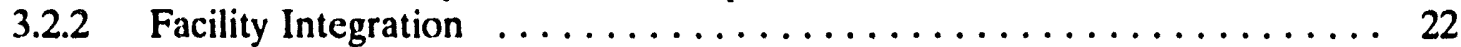

3.3 Cost Bases, Assumptions, and Assessments $\ldots \ldots \ldots \ldots \ldots \ldots \ldots \ldots \ldots \ldots$

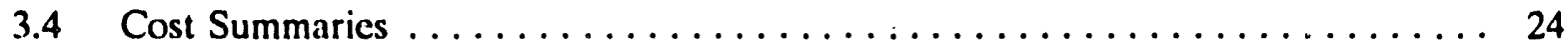

4. INCINERATION FACILITY (COST MODULE CC) $\ldots \ldots \ldots \ldots \ldots \ldots \ldots$

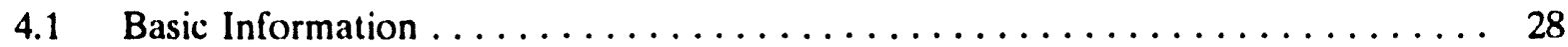

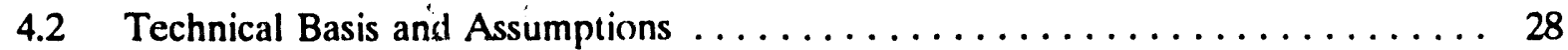

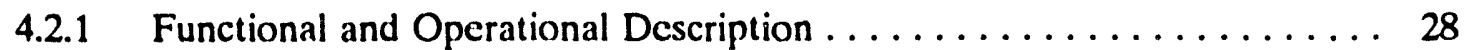

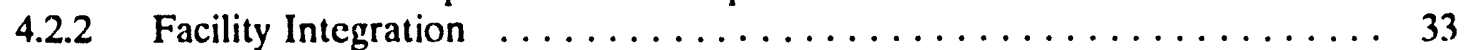

4.3 Cost Bases, Assumptions, and Assessments $\ldots \ldots \ldots \ldots \ldots \ldots \ldots \ldots \ldots \ldots$

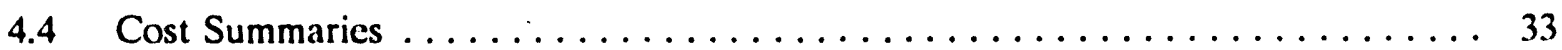

5. METAL MELTING FACILITY (COST MODULE DD) $\ldots \ldots \ldots \ldots \ldots \ldots$

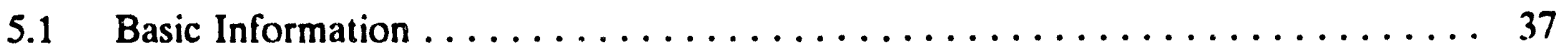

5.2 Technical Bases and Assumptions ................... 37

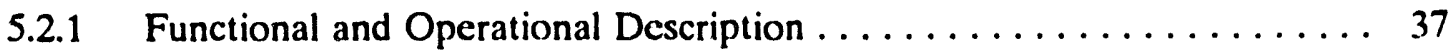

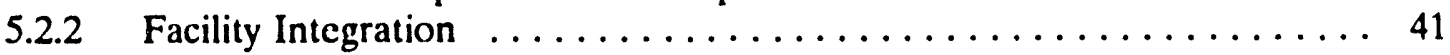

5.3 Cost Bases, Assumptions, and Assessments ................ 41

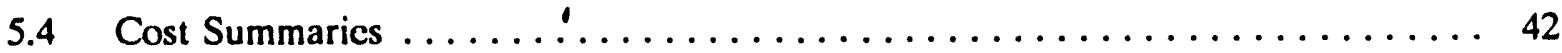

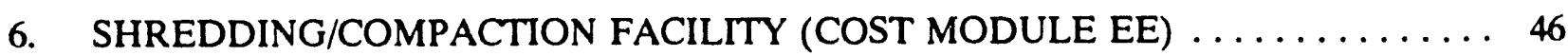

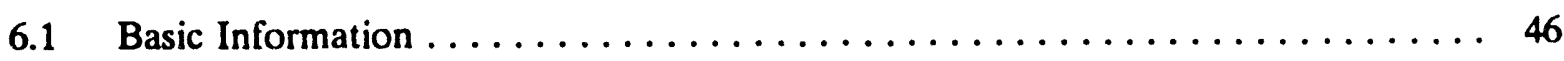

6.2 Technical Basis and Assumptions $\ldots \ldots \ldots \ldots \ldots \ldots \ldots \ldots \ldots \ldots \ldots$

6.2.1 Functional and Operational Description $\ldots \ldots \ldots \ldots \ldots \ldots \ldots \ldots$

6.2.2 Facility Integration $\ldots \ldots \ldots \ldots \ldots \ldots \ldots \ldots \ldots \ldots \ldots \ldots \ldots$

6.3 Cost Bases, Assumptions, and Assessments . . . . . . . . . . . . . 49

6.4 Cost Summaries $\ldots \ldots \ldots \ldots \ldots \ldots \ldots \ldots \ldots \ldots \ldots \ldots \ldots \ldots \ldots \ldots \ldots$ 
7. SOLIDIFICATION FACILITY (COST MODULE FF) $\ldots \ldots \ldots \ldots \ldots \ldots$

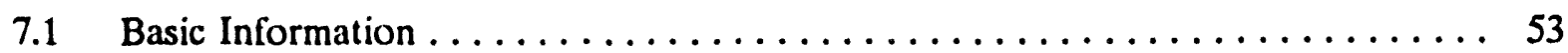

7.2 Technical Basis and Assumptions $\ldots \ldots \ldots \ldots \ldots \ldots \ldots \ldots \ldots \ldots \ldots \ldots \ldots \ldots \ldots \ldots$

7.2.1 Functional and Operational Description ............... 53

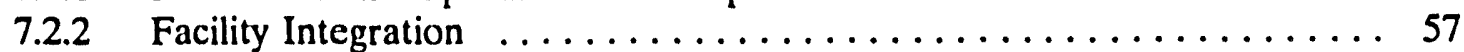

7.3 Cost Bases, Assumptions and Assessments $\ldots \ldots \ldots \ldots \ldots \ldots \ldots \ldots$

7.4 Cost Summaries $\ldots \ldots \ldots \ldots \ldots \ldots \ldots \ldots \ldots \ldots \ldots \ldots \ldots$

8. VITRIFICATION FACILITY (COST MODULE.GG) $\ldots \ldots \ldots \ldots \ldots \ldots$

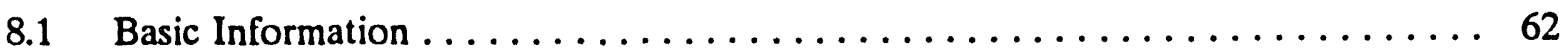

8.2 Technical Bases and Assumptions . . . . . . . . . . . . . . . 62

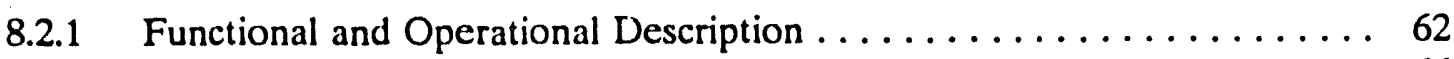

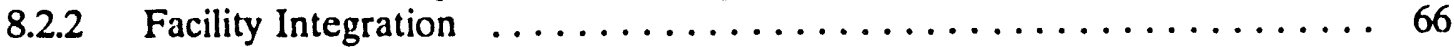

8.3 Cost Bases, Assumptions and Assessments $\ldots \ldots \ldots \ldots \ldots \ldots \ldots \ldots$

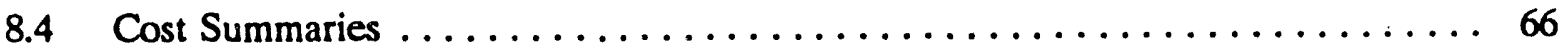

9. WET-AIR OXIDATION FACILITY (COST MODULE HH) $\ldots \ldots \ldots \ldots \ldots$

9.1 Basic Information $\ldots \ldots \ldots \ldots \ldots \ldots \ldots \ldots \ldots \ldots \ldots \ldots \ldots$

9.2 Technical Bases and Assumptions . . . . . . . . . . . . . . . 70

9.2.1 Functional and Operational Description ............... 70

9.2.2 Facility Integration $\ldots \ldots \ldots \ldots \ldots \ldots \ldots \ldots \ldots \ldots \ldots \ldots \ldots$

9.3 Cost Bases, Assumptions and Assessments $\ldots \ldots \ldots \ldots \ldots \ldots \ldots \ldots \ldots$

9.4 Cost Summaries $\ldots \ldots \ldots \ldots \ldots \ldots \ldots \ldots \ldots \ldots \ldots \ldots \ldots \ldots \ldots \ldots$

10. METAL SIZING/DECONTAMINATION FACILITY (COST MODULE II) . . . . . 78

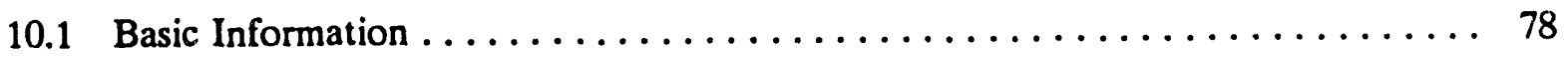

10.2 Technical Basis and Assumptions $\ldots \ldots \ldots \ldots \ldots \ldots \ldots \ldots \ldots \ldots$

10.2.1 Functional and Operational Description $\ldots \ldots \ldots \ldots \ldots \ldots \ldots \ldots \ldots$

10.2.2 Facility Integration $\ldots \ldots \ldots \ldots \ldots \ldots \ldots \ldots \ldots \ldots \ldots \ldots \ldots \ldots$ 
10.3 Cost Bases, Assumptions and Assessments $\ldots \ldots \ldots \ldots \ldots \ldots \ldots \ldots$

10.4 Cost Summaries $\ldots \ldots \ldots \ldots \ldots \ldots \ldots \ldots \ldots \ldots \ldots \ldots \ldots \ldots \ldots$

11. ENCLOSED VAULT STORAGE FACILITY (COST MODULE $Z$ ) $\ldots \ldots \ldots 5$

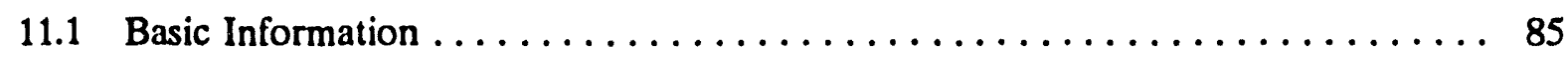

11.2 Technical Basis and Assumptions $\ldots \ldots \ldots \ldots \ldots \ldots \ldots \ldots \ldots \ldots \ldots \ldots \ldots \ldots \ldots$

11.2.1 Functional and Operational Description .............. 85

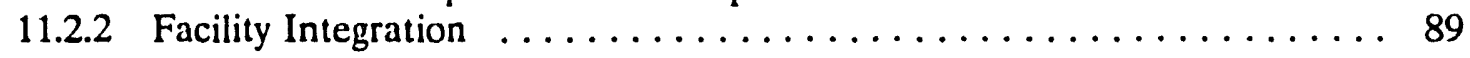

11.3 Cost Bases, Assumptions and Assessments $\ldots \ldots \ldots \ldots \ldots \ldots \ldots$

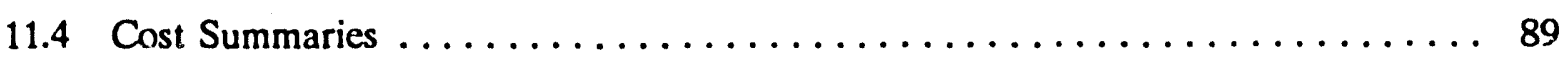

12. SILO STORAGE FACILITY (COST MODULE MM) ............. 93

12.1 Basic Information $\ldots \ldots \ldots \ldots \ldots \ldots \ldots \ldots \ldots \ldots \ldots \ldots \ldots \ldots \ldots$

12.2 Technical Bases and Assumptions . . . . . . . . . . . . 93

12.2.1 Functional and Operational Description ............... 93

12.2.2 Facility Integration $\ldots \ldots \ldots \ldots \ldots \ldots \ldots \ldots \ldots \ldots \ldots \ldots \ldots \ldots$

12.3 Cost Bases, Assumptions and Assessments $\ldots \ldots \ldots \ldots \ldots \ldots \ldots \ldots$

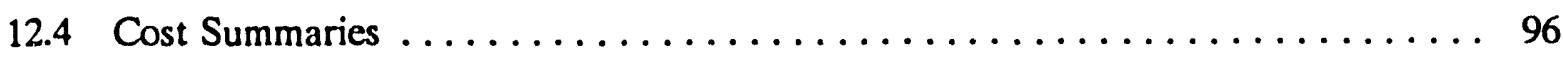

13. HLW/GTCC LLW GEOLOGIC REPOSITORY (COST MODULE JJ) . . . . . . . 100

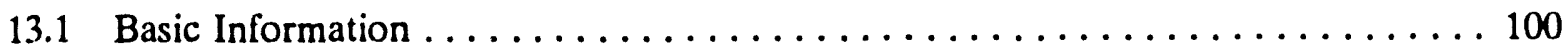

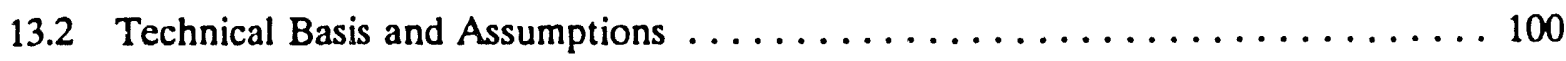

13.3 Cost Basis, Assumptions, and Assessments $\ldots \ldots \ldots \ldots \ldots \ldots \ldots \ldots \ldots \ldots$

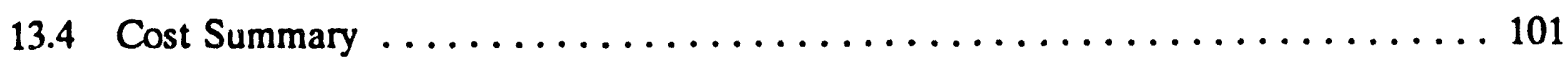

14. DISPOSAL FRONT-END SUPPORT FACILITY (COST MODULE O) $\ldots \ldots \ldots 102$

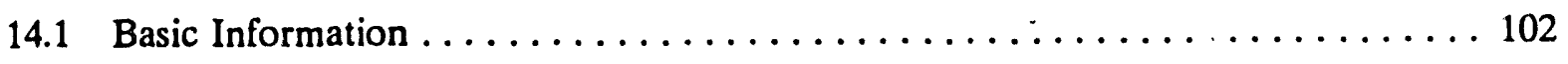

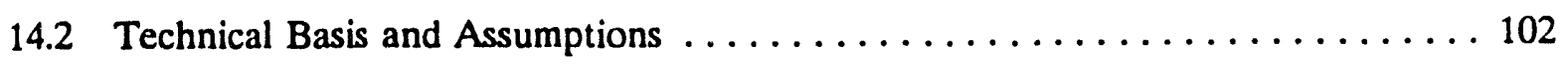

14.2.1 Functional and Operational Description ............... 102

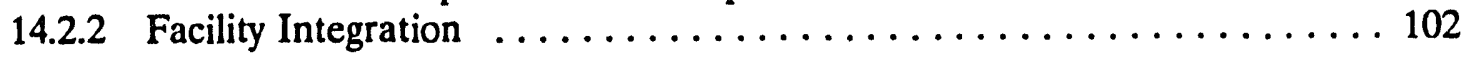


14.3 Cost Bases, Assumptions and Assessments $\ldots \ldots \ldots \ldots \ldots \ldots \ldots \ldots \ldots \ldots \ldots \ldots \ldots$

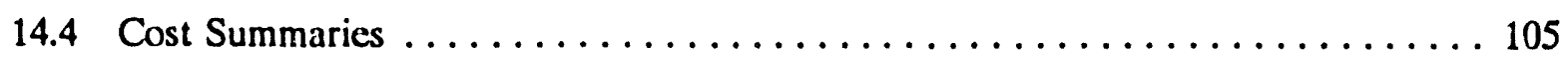

15. ENGINEERED DISPOSAL FACILITIES (COST MODULES P AND Q) . . . . 109

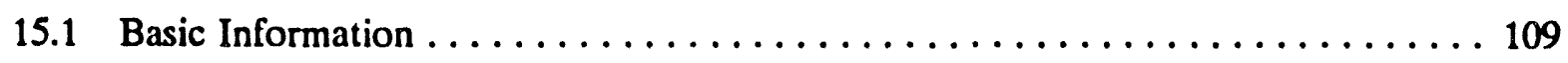

15.2 Technical Basis and Assumptions $\ldots \ldots \ldots \ldots \ldots \ldots \ldots \ldots \ldots \ldots \ldots \ldots \ldots \ldots \ldots \ldots \ldots$

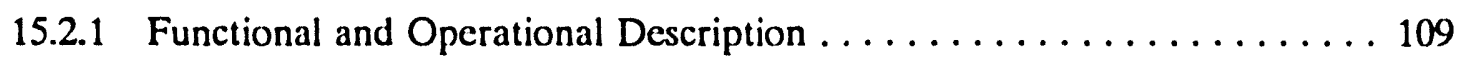

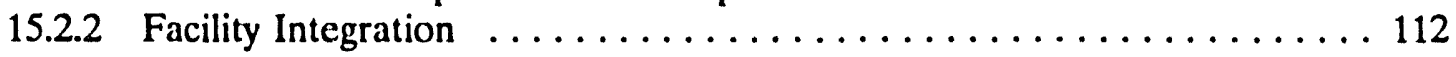

15.3 Cost Bases, Assumptions and Assessments $\ldots \ldots \ldots \ldots \ldots \ldots \ldots \ldots \ldots \ldots$

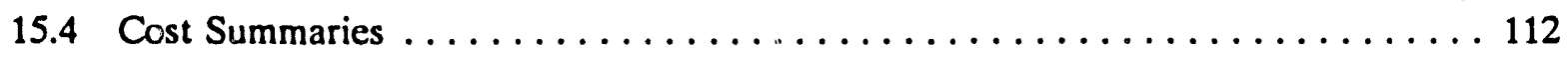

16. GTCC LLW INTERMEDIATE DEPTH DISPOSAL FACILITY (COST

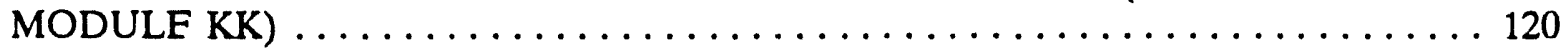

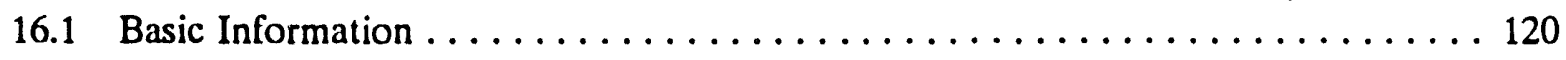

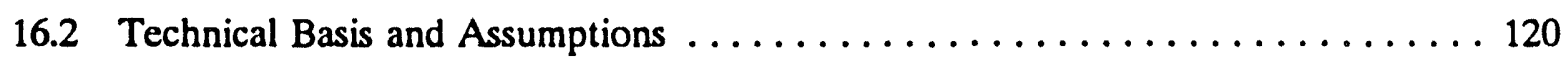

16.2.1 Functional and Operational Description ............... 120

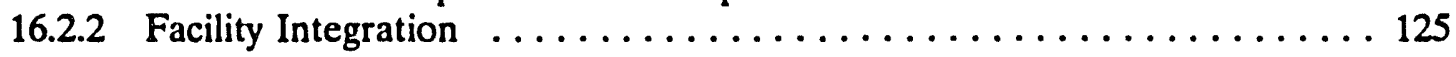

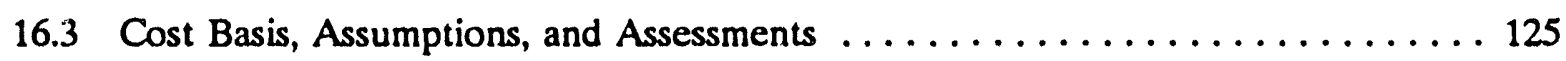

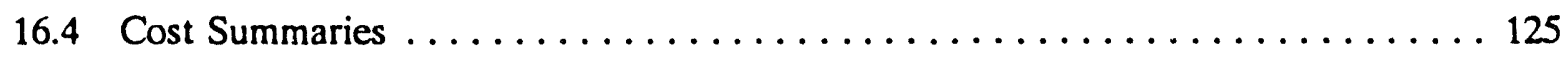

17. SHALLOW LAND DISPOSAL FACILITY (COST MODULE R) . . . . . . . 129

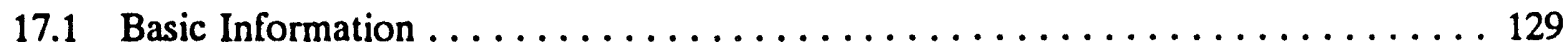

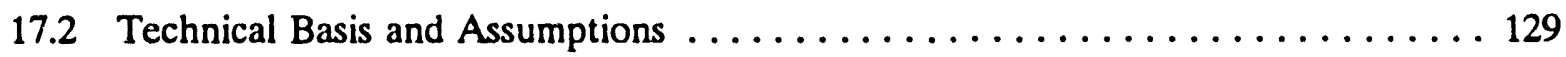

17.3 Cost Bases, Assumptions, and Assessments . . . . . . . . . . . . 129

18. SCENARIO COSTING PROCEDURE $\ldots \ldots \ldots \ldots \ldots \ldots \ldots \ldots \ldots \ldots \ldots \ldots$

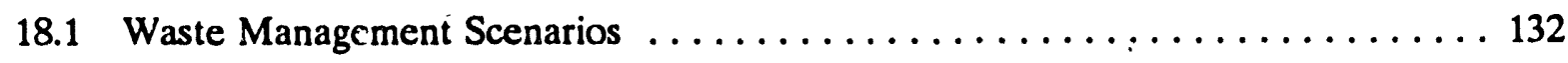

18.2 Cost Modules and Unit Operations $\ldots \ldots \ldots \ldots \ldots \ldots \ldots \ldots \ldots \ldots \ldots \ldots \ldots \ldots \ldots$

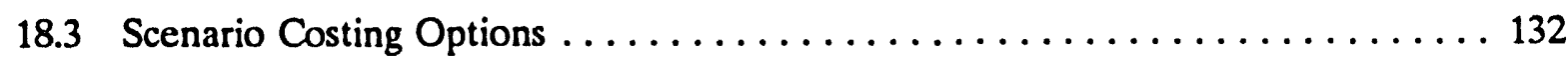

18.4 Information Required to Cost a Scenario $\ldots \ldots \ldots \ldots \ldots \ldots \ldots \ldots \ldots \ldots$ 


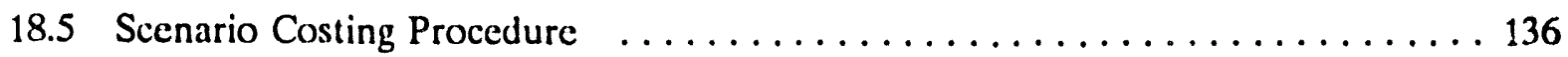

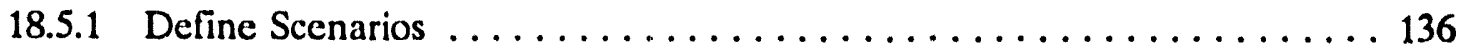

18.5.2 Define Parameters ............................... 136

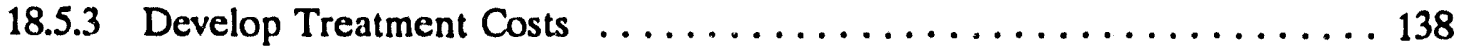

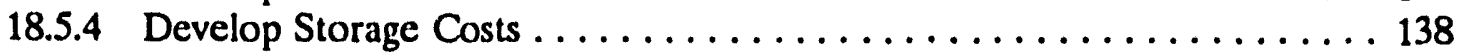

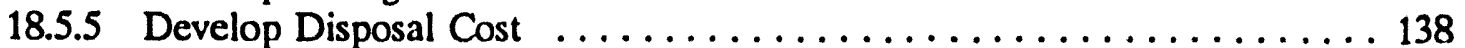

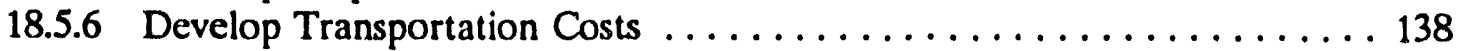

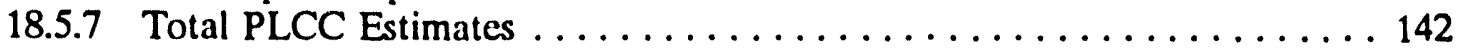

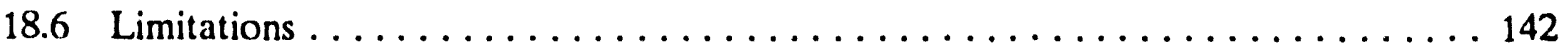

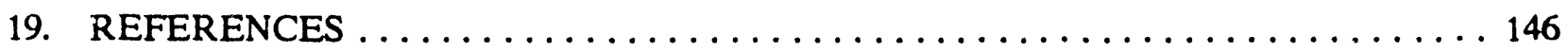

Appendix A-Methodology, Assumptions, and Bases $\ldots \ldots \ldots \ldots \ldots \ldots \ldots \ldots \ldots$

FIGURES

1-i. Waste management facility cost modules $\ldots \ldots \ldots \ldots \ldots \ldots \ldots \ldots \ldots \ldots$

1-2. PLCC cost estimating steps $\ldots \ldots \ldots \ldots \ldots \ldots \ldots \ldots \ldots \ldots \ldots \ldots \ldots \ldots \ldots \ldots \ldots \ldots \ldots \ldots \ldots$

1-3. Procedure for developing GTCC LLW management PLCC estimates from the

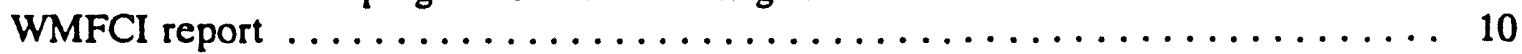

2-1. Cost versus capacity histogram for GTCC LLW administration support facility (cost module LL)

3-1. GTCC LLW receiving, preparation, and shipping large facility floor plan (cost module $\mathrm{BB}$ )

3-2. GTCC LLW receiving, preparation, and shipping small facility floor plan (cost module BB)

3-3. Process functional diagram for GTCC LLW receiving, preparation, and shipping facility (cost module BB)

3-4. Cost versus capacity histogram for GTCC LLW receiving, preparation, and

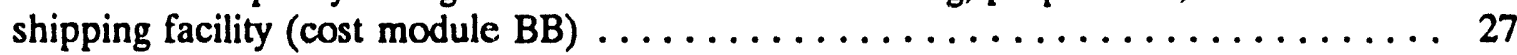

4-1. GTCC LLW incineration facility plan (cost module CC) . . . . . . . . . 29

4-2. Process functional diagram for GTCC LLW incineration facility (cost

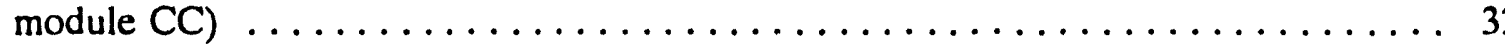

4-3. Cost versus capacity histogram for GTCC LLW incineration facility (cost

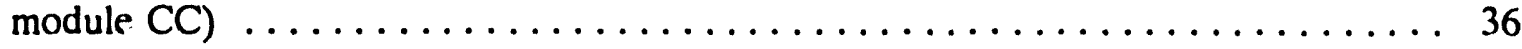

5-1. GTCC LLW metal melting facility plan (cost module DD) $\ldots \ldots \ldots \ldots$ 
5-2. Process functional diagram for GTCC LLW metal melting facility (cost module DD) $\ldots \ldots \ldots \ldots \ldots \ldots \ldots \ldots \ldots \ldots \ldots \ldots \ldots \ldots \ldots \ldots \ldots$

5-3. Cost versus capacity histogram for GTCC LLW metal melting facility (cost

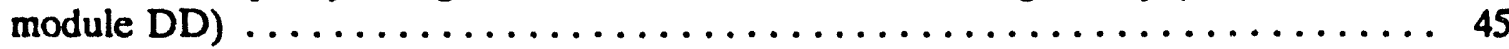

6-1. GTCC LLW shredding/compaction facility plan (cost module EE) . . . . . . 47

6-2. Process functional diagram for GTCC LLW shredding/compaction facility (cost module EE) $\ldots \ldots \ldots \ldots \ldots \ldots \ldots \ldots \ldots \ldots \ldots \ldots \ldots \ldots \ldots \ldots \ldots \ldots \ldots \ldots \ldots$

6-3. Cost versus capacity histogram for GTCC LLW shredding/compaction facility

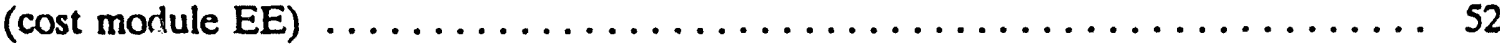

7-1. GTCC LLW solidification facility plan (cost module FF) $\ldots \ldots \ldots \ldots \ldots \ldots$

7-2. GTCC LLW process functional diagram for solidification facility (cost

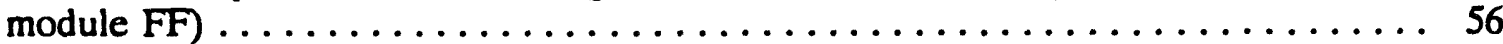

7-3. Cost versus capacity histogram for GTCC LLW solidification facility (cost

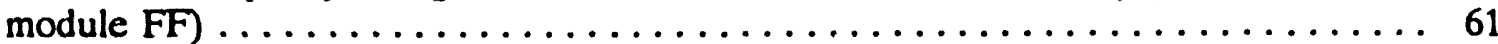

8-1. GTCC LLW vitrification facility plan (cost module GG) $\ldots \ldots \ldots \ldots \ldots \ldots$

8-2. Process functional diagram for GTCC LLW vitrification facility (cost

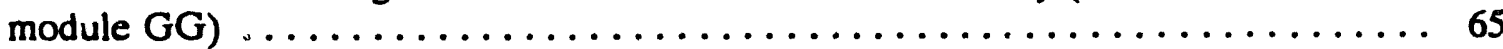

8-3. Cost versus capacity histogram for GTCC LLW vitrification facility (cost

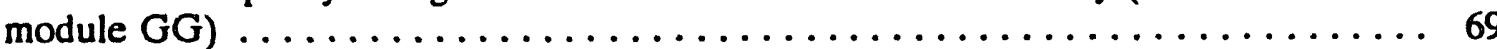

9-1. GTCC LLW wet-air oxidation facility plan (cost module $\mathrm{HH}) \ldots \ldots \ldots \ldots$

9-2. Process functional diagram for GTCC LLW wet-air oxidation facility (cost module $\mathrm{HH}) \ldots \ldots \ldots \ldots \ldots \ldots \ldots \ldots \ldots \ldots \ldots \ldots \ldots \ldots \ldots \ldots$

9-3. Cost versus capacity histogram for GTCC LLW wet-air oxidation facility (cost module $\mathrm{HH}) \ldots \ldots \ldots \ldots \ldots \ldots \ldots \ldots \ldots \ldots \ldots \ldots \ldots \ldots \ldots \ldots$

10-1. GTCC LLW metal sizing/decontamination facility plan (cost module II) . . . . . . 79

10-2. Process functional diagram for GTCC LLW metal sizing/decontamination facility (cost module II) $\ldots \ldots \ldots \ldots \ldots \ldots \ldots \ldots \ldots \ldots \ldots \ldots \ldots \ldots \ldots \ldots$

10-3. Cost versus capacity histogram for GTCC LLW metal sizing/decontamination facility (cost module II) $\ldots \ldots \ldots \ldots \ldots \ldots \ldots \ldots \ldots \ldots \ldots \ldots \ldots \ldots \ldots$

11-1. GTCC LLW vault storage facility plan (cost module $Z$ ) $\ldots \ldots \ldots \ldots$

11-2. Perspective view of vault storage concept (cost module $Z$ ) $\ldots \ldots \ldots \ldots \ldots$ 
11-3. Process functional diagram for GTCC LLW vault storage facility (cost module $\mathrm{Z}$ ) ...

11-4. Cost versus capacity histogram for GTCC LLW vault storage facility (cost

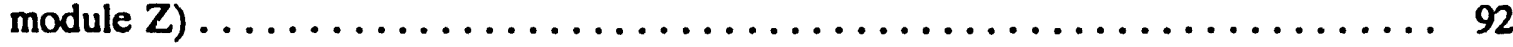

12-1. GTCC LLW silo storage facility plan (cost module MM) . . . . . . . . . 94

12-2. Process functional diagram for GTCC LLW silo storage facility (cost

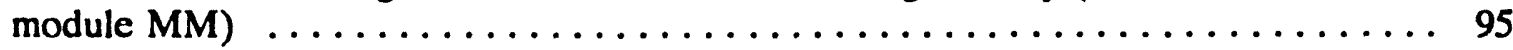

12-3. Cost versus capacity histogram for GTCC LLW silo storage facility (cost module $\mathrm{MM})$................................... 99

14-1. Disposal front-end facility process functional diagram (cost module 0 ) $\ldots \ldots 103$

14-2. Cost vs. capacity histogram for disposal front-end facility (cost module 0 ) $\ldots \ldots 108$

15-1. Engineered disposal facility plan (cost modules $\mathrm{P}$ and $\mathrm{Q}) \ldots \ldots \ldots \ldots$

15-2. Process functional diagram for engineered disposal facility (cost modules $P$

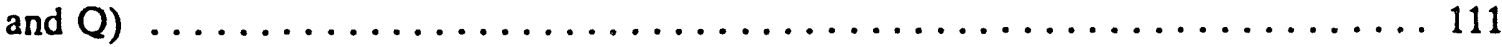

15-3. Cost versus capacity histogram for engineered disposal facility (cost module P) . . . 118

15-4. Cost versus capacity histogram for engineered disposal facility (cost module Q) . . . 119

16-1. GTCC LLW intermediate depth disposal facility plan (cost module KK) . . . . . . 121

16-2. Process functional diagram for GTCC LLW intermediate depth waste disposal

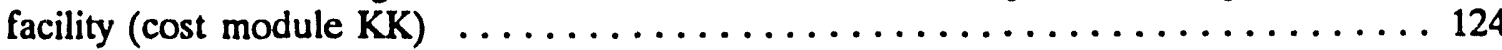

16-3. Cost versus capacity histogram for GTCC LLW intermediate depth disposal

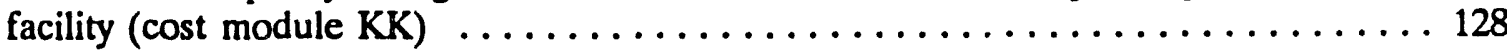

17-1. Cost comparison of commercial waste disposal facilities $\ldots \ldots \ldots \ldots \ldots \ldots 131$

18-1. Key events in the acquisition process $\ldots \ldots \ldots \ldots \ldots \ldots \ldots \ldots \ldots \ldots$

\section{TABLES}

1-1. A subcategory breakdown of the commercially generated GTCC LLW base case volume estimates in cubic feet (Hulse 1991$) \ldots \ldots \ldots \ldots \ldots \ldots \ldots \ldots \ldots$

2-1. Estimated operating staff for GTCC LLW administration support facility (cost

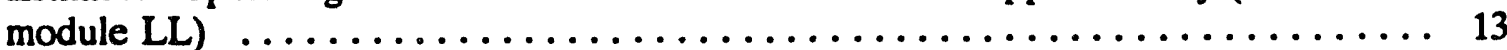

2-2. Capacity and unit cost for administration support facility (cost module LL) . . . . . 14

2-3. PLCC estimate summary for GTCC LLW administration support facility (cost module LL) 
3-1. Estimated operating staff for GTCC LLW recciving, preparation, and shipping tacility (cost module BB)

3-2. Capacities and unit costs for GTCC LLW receiving, preparation, and shipping facility (cost module BB)

3-3. PLCC estimate summary for GTCC LLW receiving, preparation, and shipping facility (cost module BB)

4-1. Estimated operating staff for GTCC LLW incineration facility (cost module CC) . . 34

4-2. Capacities and unit costs for GTCC LLW incineration facility (cost module CC) . . . 34

4-3. PLCC estimate summary for GTCC LLW incineration facility (cost module CC) . . . 35

5-1. Estimated operating staff for GTCC LLW metal melting facility (cost

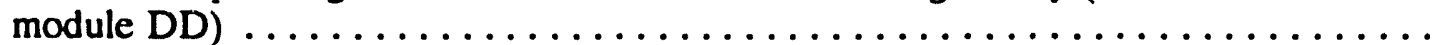

5-2. Capacities and unit costs for GTCC LLW metal melting facility (cost module DD)

5-3. PLCC estimate summary for GTCC LLW metal melting facility (cost

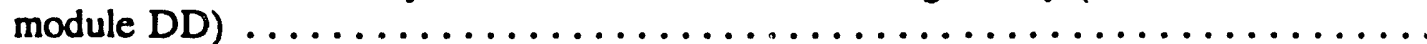

6-1. Estimated operating staff for GTCC LLW shredding/compaction facility (cost module EE)

6-2. Capacities and unit cost for GTCC LLW shredding/compaction facility (cost module EE)

6-3. PLCC estimate summary for GTCC LLW shredding/compaction facility (cost module EE)

7-1. Estimated operating staff for GTCC LLW solidification facility (cost module FF)

7-2. Capacities and unit cost for GTCC LLW solidification facility (cost module FF)

7-3. PLCC estimate summary for GTCC LLW solidification facility (cost module FF)

8-1. Estimated operating staff for GTCC LLW vitrification facility (cost module GG)

8-2. Capacities and unit costs for GTCC LLW vitrification facility (cost module GG)

8-3. PLCC estimate summary for GTCC LLW vitrification facility (cost module GG) 
9-1. Estimated operating staff for GTCC LLW wet-air oxidation facility (cost

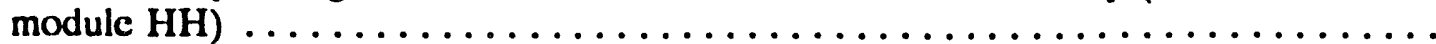

9-2. Capacities and unit costs for GTCC LLW wet-air oxidation facility (cost module $\mathrm{HH}$ )

9-3. PLCC estimate summary for GTCC LLW wet-air oxidation facility (cost

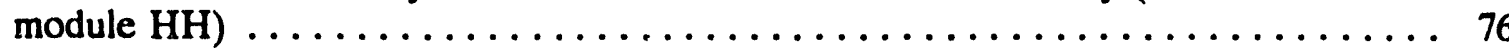

10-1. Estimated operating staff for GTCC LLW metal sizing/decontamination facility (cost module II)

10-2. Capacities and unit costs for metal sizing/decontamination facility (cost

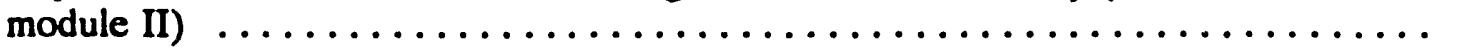

10-3. PLCC estimate summary for metal sizing/decontamination facility (cost

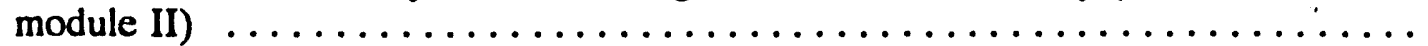

11-1. Estimated operating staff for GTCC LLW vault storage facility loading/

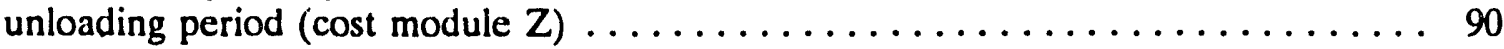

11-2. Capacity and unit cost for GTCC LLW vault storage facility (cost module Z) . . . 90

11-3. PLCC estimate summary for GTCC LLW vault storage facility (cost module Z) . . 91

12-1. Estimated operating staff for GTCC LLW silo storage facility loading/unloading period (cost module MM)

12-2. Capacities and unit costs for GTCC LLW silo storage facility (cost module MM)

12-3. PLCC estimate summary for GTCC LLW silo storage facility (cost module MM)

14-1. Estimated operating staff for disposal front-end facility (cost module O) $\ldots \ldots \ldots 104$

14-2. Capacities and unit costs for disposal front-end facility (cost module 0) $\ldots \ldots \ldots 104$

14-3. PLCC estimate summary for disposal common support facility (cost module O) . . . 106

14-4. PLCC estimate summary for disposal common support facility (cost module O) . . . 107

15-1. Estimated operating staff for engineered disprsal facility (cost modules $\mathbf{P}$

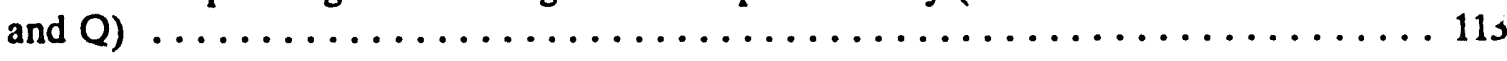

15-2. Capacities and unit costs for engineered disposal facility (cost module $P$ and $Q$ ) $\ldots 113$

15-3. PLCC estimate summary for engineered facility (cost module P) $\ldots \ldots \ldots \ldots \ldots$

15-4. PLCC estimate summary for engineered facility (cost module P) $\ldots \ldots \ldots \ldots$ 
15-5. PLCC estimate summary for engineered RCRA disposal facility (cost

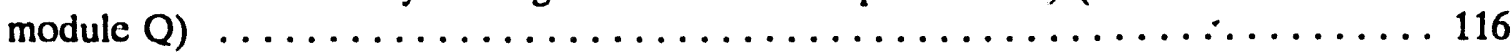

15-6. PLCC estimate summary for engineered RCRA disposal facility (cost

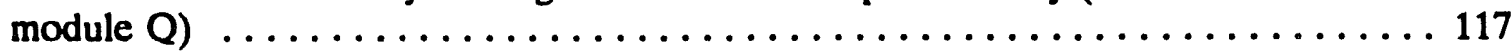

16-1. Estimated operating staff for GTCC LLW intermediate depth disposal facility (cost module KK)

16-2. Capacities and unit costs for GTCC LLW intermediate depth disposal facility (cost module $\mathrm{KK}$ )

16-3. PLCC estimate summary for GTCC LLW intermediate depth disposal facility (cost module KK)

17-1. Shallow land disposal closure cost versus capacity (cost module $R$ ) $\ldots \ldots \ldots \ldots 130$

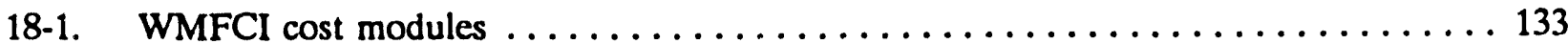

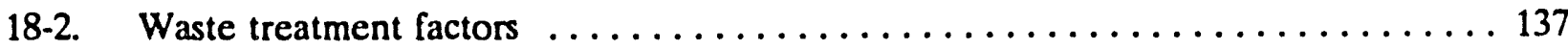

18-3. Summary cost versus capacity for treatment facilities $\ldots \ldots \ldots \ldots \ldots \ldots \ldots \ldots$

18-4. Summary of cost versus capacity for storage facilities $\ldots \ldots \ldots \ldots \ldots \ldots \ldots \ldots 140$

18-5. Summary of cost versus capacity for disposal facilities $\ldots \ldots \ldots \ldots \ldots \ldots \ldots 141$

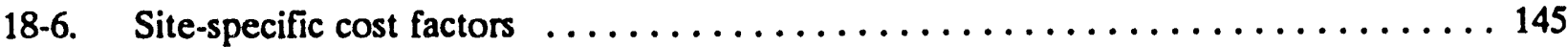




\section{ACRONYMS}
ALARA as low as reasonably achievable
BNFL British Nuclear Fuel Limited
B\&W Babcock \& Wilcox
CFR Code of Federal Regulations
$\mathrm{CM}$ construction management
D\&D decontamination \& decommissioning
DOE U.S. Department of Energy
DOT U.S. Department of Transportation
EA Environmental Assessment
EG\&G Idaho EG\&G Idaho, Inc.
EIS Environmental Impact Statement
F\&OR functional and operational requirement
FY fiscal year
GOCO government owned and contractor operated
GTCC Greater-Than-Class C
HDPE high density polyethylene
HEPA high-efficiency particulate air (filter)
HVAC heating, ventilating, and air conditioning
LDR Land Disposal Restriction
LICP line item construction project
LLRWPAA Low-Level Radioactive Waste Policy .Imendment Act
- LLW low-level waste
LWR light water reactor
MCC motor control center 
MLLW mixed low-lcvel waste

NEPA National Environmental Policy Act of 1969

NRC U.S. Nuclear Regulatory Commission

O\&M operations \& maintenance

PAN passive/active neutron

PEIS Programmatic Environmental Impact Statement

PFD process functional diagram

PLCC planning life-cycle cost

PNL Pacific Northwest Labc iatories

QAVC quality assurance/quality control

RCRA Resource Conservation and Recovery Act

RHMMS Radiological and Hazardous Material Measurement System

RTR real-time radiography

RWMC Radioactive Waste Management Complex at INEL

SGS segmented gamma scanning

SNF spent nuclear fuel

SPAR specific performance assessment required

SSL scoping study layout

TRU transuranic

TRUPACT-II Transuranic Package Transporter II

TSD treatment, storage, and dir nosal

WAO Wet-Air Oxidation Facility

WMFCI Waste Management Facility Cost Information 


\section{Waste Management Facilities Cost Information Report for Greater-Than-Class C and DOE Equivalent Special Case Waste}

\section{INTRODUCTION AND SUMMARY}

\subsection{Background}

The Waste Management Facility Cost Information (WMFCI) report series contain cost information on the U.S. Department of Energy (DOE) Complex waste streams that will be addressed by the DOE in a Programmatic Environmental Impact Statement (PEIS) project. The first report (EGG WTD-10443) covers treatment, storage, and disposal (TSD) facilities that will be needed for management of low-level waste and mixed low-level waste, (LLW/MLLW), alpha LLW/MLLW, and transuranic (TRU) waste streams. The second report (EGG-WM-10670) covers the characterization, canning, and storage of spent nuclear fuel (SNF) and related hardware and scrap metal. Facility cost modules $A$ through AA are covered in these two reports. This third report describes the results of a task commissioned by DOE to develop cost information for TSD facilities that will be needed to manage commercial Greater-Than-Class C low-leve! waste (GTCC LLW) and DOE equivalent special case waste. ${ }^{a}$ The GTCC LLW terminology refers to a special category of commercially generated waste considered incompatible with the currently practiced method of shallow-land disposal used for other classes of commercial low-level radioactive waste. In 1985, Congress assigned the responsibility for managing this waste stream to DOE. Although the term GTCC LLW is not applicable to any of the DOE-generated waste streams, some DOE waste streams (as determined by D. Kudera and others of EG\&G Idaho) could be managed by the same methods used for GTCC LLW. Hence, TSD facilities covered in this report could also be applied to DOE equivalent waste.

The Planning Life Cycle Cost (PLCC) estimates in the WMFCI reports are based on a set of facility cost riodules, each of which may be used alone or combined. All facilities are assumed to be government owned and contractor operated (GOCO).

PLCC estimates are provided for GTCC LLW waste management facilities with two different sizes and throughput capacities. TSD facilities with smaller capacities are sized to handle the estimated base case volumes for commercially produced GTCC LLW given in DOE/LLW-114 (Hulse 1991). Facilities with larger capacities are based on the assumption that one of the DOE equivalent waste streams (specific performance assessment required (SPAR) waste) will be handled by the same facilities used for the GTCC LLW. A breakdown of the GTCC LLW base case volumes used for

a. Commercial GTCC LLW is any low-level radioactive waste that has a radionuclide concentration exceeding the Class C LLW limits set forth by the Nuclear Regulatory Commission (NRC) stipulated in 10 Code of Federal Regulation, Part 61 (10 CFR 61), Licensing Requirements for Land Disposal of Radioactive Waste. According to this regulation, only Classes A, B, and C LLW can be disposed of in a near surface disposal facility. Any commercially produced low-level radioactive waste having generally a radionuclide concentration higher than Class $C$ is not covered by 10 CFR 61, and there is no other regulation that applies to the disposal of this waste. Through the Low-Level Radioactive Waste Policy Amendment Act of 1985, Congress assigned DOE the responsibility for managing and permanently disposing of the commercially produced GTCC LLW. 
sizing the throughput of the small facilities is presented in Table 1-1. The estimated volume of SPAR waste is $1,200,540 \mathrm{ft}^{3}$, with no detailed breakdown available at this time. Hence, for sizing the throughput capacity for the large facilities, the percentage of the various subcategories of the SPAR waste is arbitrarily assumed to be the same as the commercially generated GTCC LLW. In this report, it is assumed that TRU concentrations of this waste justifies alpha cell confinement.

To develop treatment facility mass flow rates, a density for each waste type is assumed. These densities, shown in Table 1-2, will require verification through additional source surveys.

Cost information in this report is based on the best available knowledge about waste processing requirements, technology availability, and cost data. The information in this report may have to be updated when additional knowledge is gained in these areas.

\subsection{WMFCl Task Participants}

The WMFCI task was performed by a project team from EG\&G Idaho, Inc. and the Environmental Services Division of Morrison Knudsen Corporation (MK). EG\&G Idaho and MK were selected for this task because of their combined expertise in design and construction of waste management TSD facilities for DOE sites and for the nuclear industry.

\subsection{Cost Modules and Unit Operations}

Each type of the treatment and storage facilities is referred to as a cost module. There are a total of 16 cost modules, shown in Figure 1-1. These cost modules can be assembled in various ways to create different types of treatment and storage scenarios.

In addition, each facility is broken down into several distinct functions, referred to as unit operations. Unit operations assume inclusion of all buildings, equipment, and accessories needed to accomplish the given function.

\subsection{Facility Cost Estimating Methodology}

Details of the approach used for developing PLCC estimates in this report are presented in Appendix A. Figure 1-2 shows a block diagram of the steps used in the estimating process. Initially, a capacity range for each type of facility was established by studying the waste projection data. Based on available data, two sizes, small and large, are considered for each of the facility cost modules highlighted in Figure 1-1. The base case waste volume projection for commercial GTCC LLW given in Table 1-1 is used as the capacity for the small facility. DOE equivalent waste (SPAR) volume is used as the basis for defining capacity for the large facilities. Treatment facility alternatives for GTCC LLW which are covered in this report include:

- Incineration (cost module CC)

- Metal melting (cost module DD)

- $\quad$ Shredding/compaction (cost module EE)

- Solidification (cost module FF)

- Vitrification (cost module GG) 
Table 1-1. A subcategory breakdown of th': commercially gencrated GTCC LLW base case volume estimates in cubic leet (Hulse 1991).

\begin{tabular}{|c|c|c|c|c|c|c|c|}
\hline & \multirow[t]{2}{*}{ Waste Calagory } & \multirow[t]{2}{*}{ Waste Type } & \multirow[t]{2}{*}{ Waste Form } & \multicolumn{3}{|c|}{ Waste Source } & \multirow{2}{*}{$\begin{array}{c}\text { Total } \\
\text { Volume } \\
\text { (cu.fi) }\end{array}$} \\
\hline & & & & $\begin{array}{l}\text { Utilities } \\
\text { (cu.ft) }\end{array}$ & $\begin{array}{c}\text { Otbers } \\
\text { (cu.ft) }\end{array}$ & $\begin{array}{l}\text { DOE beld } \\
\text { (cu.ft) }\end{array}$ & \\
\hline \multirow[t]{3}{*}{1} & \multirow[t]{3}{*}{ Combustible solids } & Compactible trash & Uapackaged & & & & \\
\hline & & - & Packaged & & 5014.69 & & \\
\hline & & Subrotal & Packaged & & 5014.69 & & 5015 \\
\hline \multirow[t]{10}{*}{2} & \multirow[t]{10}{*}{ Semicombustible Solids } & \multirow[t]{2}{*}{ Cartridge filters } & Uapackaged & 4979.37 & & & \\
\hline & & & Packaged & 9358.40 & 1624.48 & & \\
\hline & & \multirow{2}{*}{ Solidified resins } & Unpackaged & & & & \\
\hline & & & Packaged & & 565.04 & & \\
\hline & & \multirow{3}{*}{ Solidified organic liquids } & Unoackaged & & & & \\
\hline & & & Packaged & & 219.66 & & \\
\hline & & & & & & & \\
\hline & & \multirow[t]{3}{*}{ Filter Media } & Unpackaged & & & 35.15 & \\
\hline & & & Packaged & & .328 .4 .3 & 5700.50 & \\
\hline & & & Packaged & 9358.40 & 27.37 .60 & 5700.50 & 17796 \\
\hline \multirow[t]{3}{*}{3} & \multirow{3}{*}{ Non-Combustible Solids } & \multirow[t]{3}{*}{ Non-compactible trash - } & Unpackaged & & & & \\
\hline & & & Packaged & & 363.74 & 1893221 & \\
\hline & & & Packaged & & 363.74 & 1893221 & 19296 \\
\hline \multirow[t]{10}{*}{4} & \multirow[t]{10}{*}{ Metal Waste } & \multirow[t]{2}{*}{ Activated Metals } & Unpackaged & 1790455 & & & \\
\hline & & & Packaged & 4449652 & & 13357.43 & \\
\hline & & \multirow{2}{*}{ Contaminated Equipmeats } & Unpackaged & 1225.42 & & & \\
\hline & & & Packaged & 4509.69 & 82283 & & \\
\hline & & \multirow[t]{2}{*}{ Metals from operations } & Unpackaged & & & & \\
\hline & & & Packaged & & 104.18 & & \\
\hline & & \multirow[t]{4}{*}{ Metal shavings } & Unpackaged & & & & \\
\hline & & & Packaged & & 176.57 & & \\
\hline & & & & & & & \\
\hline & & & Packaged & 4900621 & 110358 & 13357.43 & 63467 \\
\hline
\end{tabular}


Table 1-1. (continued).

\begin{tabular}{|c|c|c|c|c|c|c|c|}
\hline & \multirow[t]{2}{*}{ Wastc Calagory } & \multirow[t]{2}{*}{ Waste Type } & \multirow[t]{2}{*}{ Waste Form } & \multicolumn{3}{|c|}{ Waste Source } & \multirow{2}{*}{$\begin{array}{c}\text { Total } \\
\text { Volume } \\
\text { (cu.ft) }\end{array}$} \\
\hline & & & & $\begin{array}{c}\text { Utilities } \\
\text { (cu.ft) } \\
\end{array}$ & $\begin{array}{c}\text { Others } \\
\text { (eu.ft) }\end{array}$ & $\begin{array}{c}\text { DOE beld } \\
\text { (cu.fi) }\end{array}$ & \\
\hline \multirow[t]{3}{*}{5} & \multirow{3}{*}{$\begin{array}{c}\text { Hetrogeneous Solids } \\
\text { (1) }\end{array}$} & \multirow[b]{3}{*}{ Subtotal } & Unpackaged & & & & \\
\hline & & & Packaged & & & & \\
\hline & & & Packaged & & & & \\
\hline \multirow[t]{6}{*}{6} & \multirow[t]{6}{*}{ Special Waste } & \multirow[t]{2}{*}{ Mixed Oxide Fuel } & Unpackaged & & & & \\
\hline & & & Packaged & & 146.56 & & \\
\hline & & \multirow[t]{3}{*}{ Sealed sources } & Unpackaged & & 5.65 & & \\
\hline & & & Packaged & & 211.89 & 14.83 & \\
\hline & & & & & $;$ & & \\
\hline & & Subtotal & Packaged & & 358.44 & $14.83 \mid$ & 373 \\
\hline \multirow[t]{3}{*}{7} & \multirow[t]{3}{*}{ Organic sludge } & \multirow[t]{2}{*}{ Ion exchange resins } & Unpackaged & 9640.91 & & & \\
\hline & & & Packaged & 9640.91 & 176.57 & & \\
\hline & & \multirow[t]{2}{*}{ Subtotal } & Packaged & 9640.91 & 176.57 & & 9817 \\
\hline & & & & Total $\mathrm{Pa}_{2}$ & kaged $C$ & GTCC LLW & 115765 \\
\hline
\end{tabular}

(1) Both compactible tash and noncompactible trash are considered to be hetrogeneous and requires sorting.

Table 1-2. Assumed density of input waste.

\begin{tabular}{|c|c|c|c|c|}
\hline & Waste Calagory & Waste Type & $\begin{array}{l}\text { Average } \\
\text { Denrity } \\
\text { nb/en(t) }\end{array}$ & $\begin{array}{c}\text { Weighted Avg. } \\
\text { Density } \\
\text { (Ib/eu.fi) }\end{array}$ \\
\hline & Combastible solids & 1 Comoactible trash & 35 & 35 \\
\hline \multirow[t]{4}{*}{2} & \multirow[t]{4}{*}{ Sesnicombustible Solids } & Canrider Glers & 35 & \multirow[b]{4}{*}{37.7} \\
\hline & & Solidified resins & 95 & \\
\hline & & Solidiried organic liguids & 95 & \\
\hline & & Fuler Media & 33 & \\
\hline \multicolumn{3}{|c|}{3 | Non-Combartible Solids I Non-compactible tresh } & 90 & 90 \\
\hline \multirow[t]{4}{*}{4} & \multirow[t]{4}{*}{ Meral Warlo } & Activated Metals & 193 & \multirow{4}{*}{-} \\
\hline & & Contaminaled Equipmears & 131 & \\
\hline & & Metak trom operations & 193 & \\
\hline & & Metal shaviag & 193 & \\
\hline \multicolumn{5}{|c|}{$5 \mid$ Herrocepeons Solids (1) | } \\
\hline \multirow{2}{*}{\multicolumn{2}{|c|}{6 Special Wasto }} & Mired Oxide Fuel & 190 & \multirow{2}{*}{190} \\
\hline & & Sealed sources & 190 & \\
\hline & Organic sladge & I lon exebange resins & 45 & 45 \\
\hline
\end{tabular}

(1) Both compactible trash and noncomot trash are considered to be herrogent 


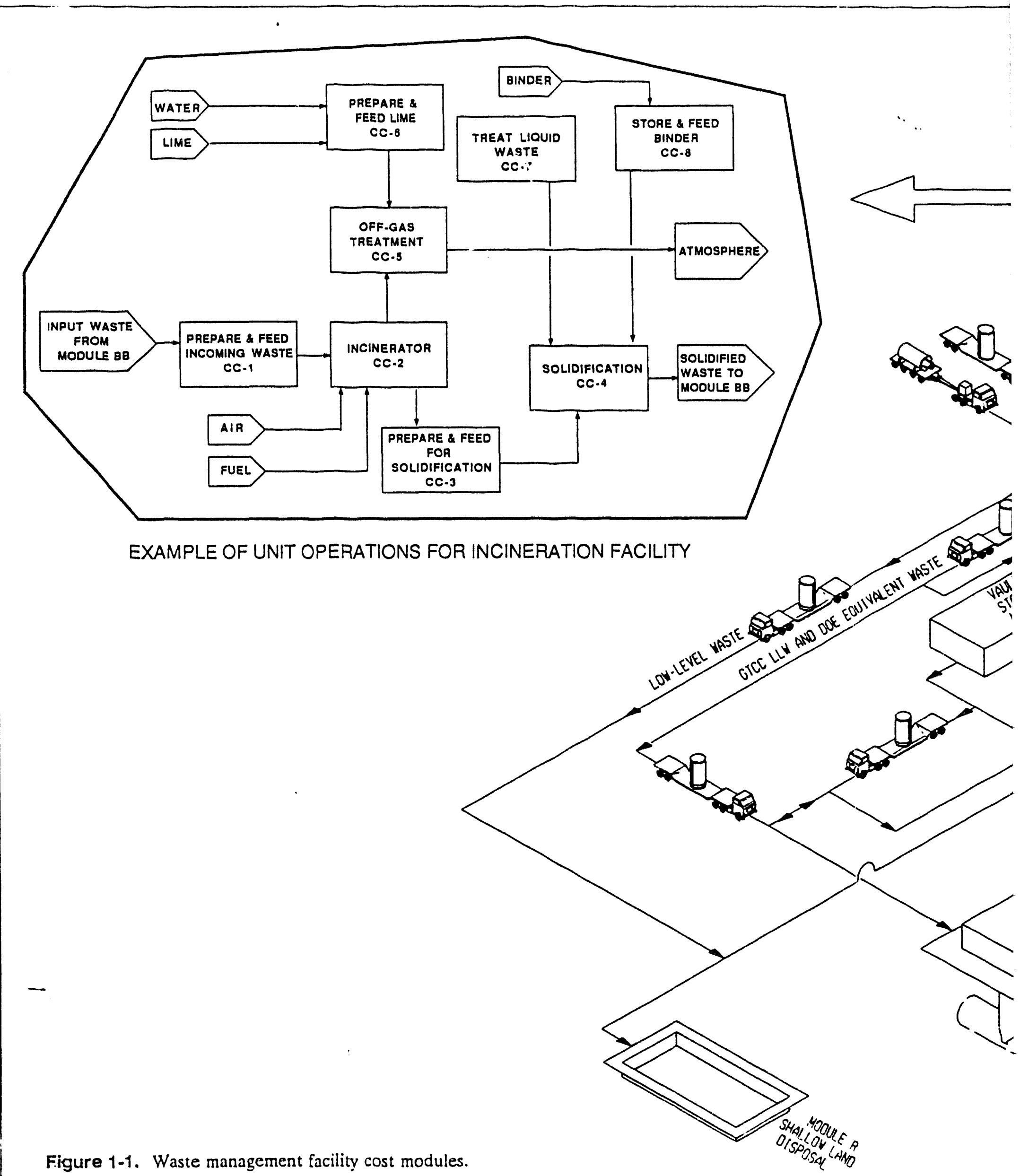

Figure 1-1. Waste management facility cost modules. 


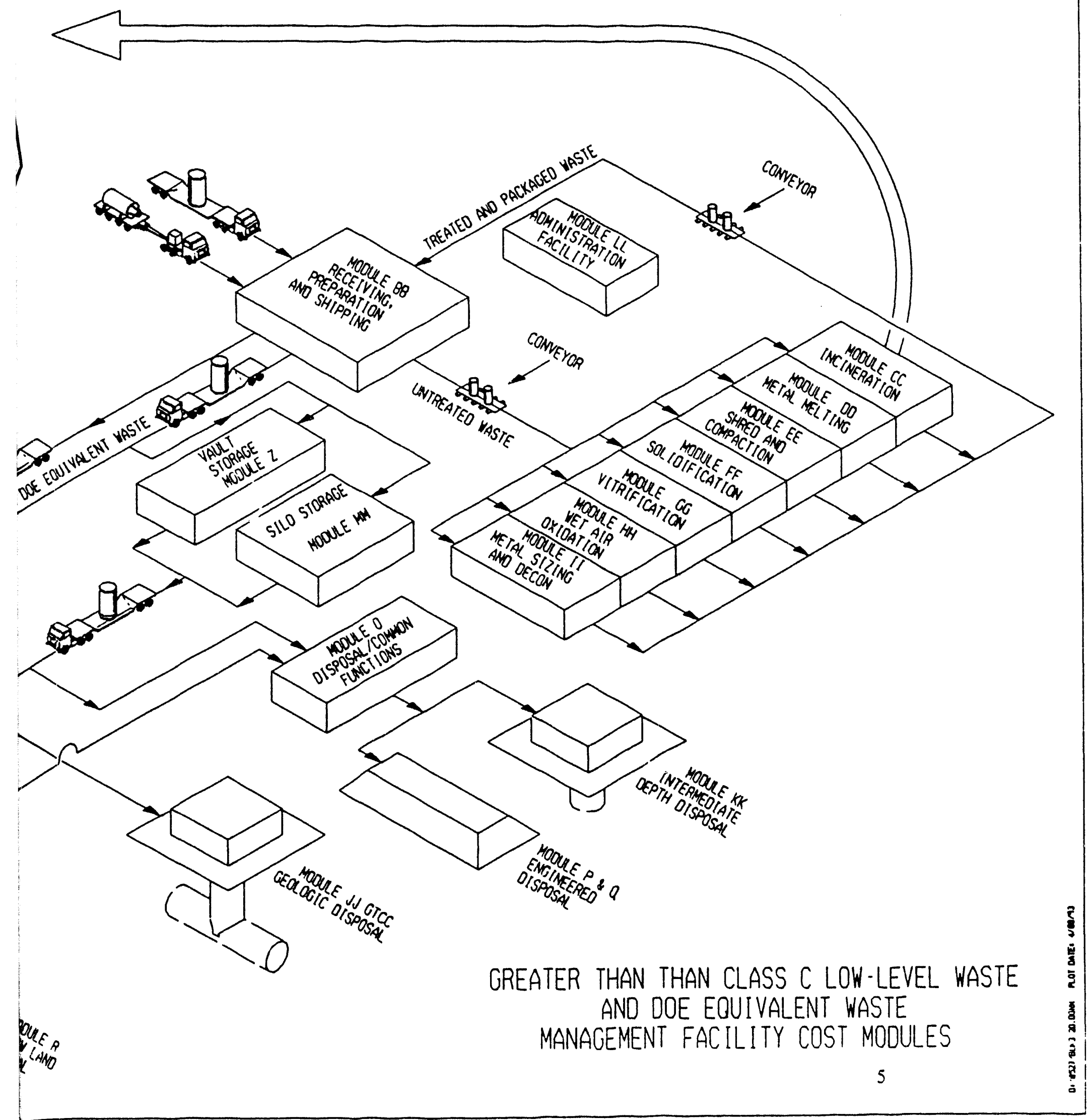




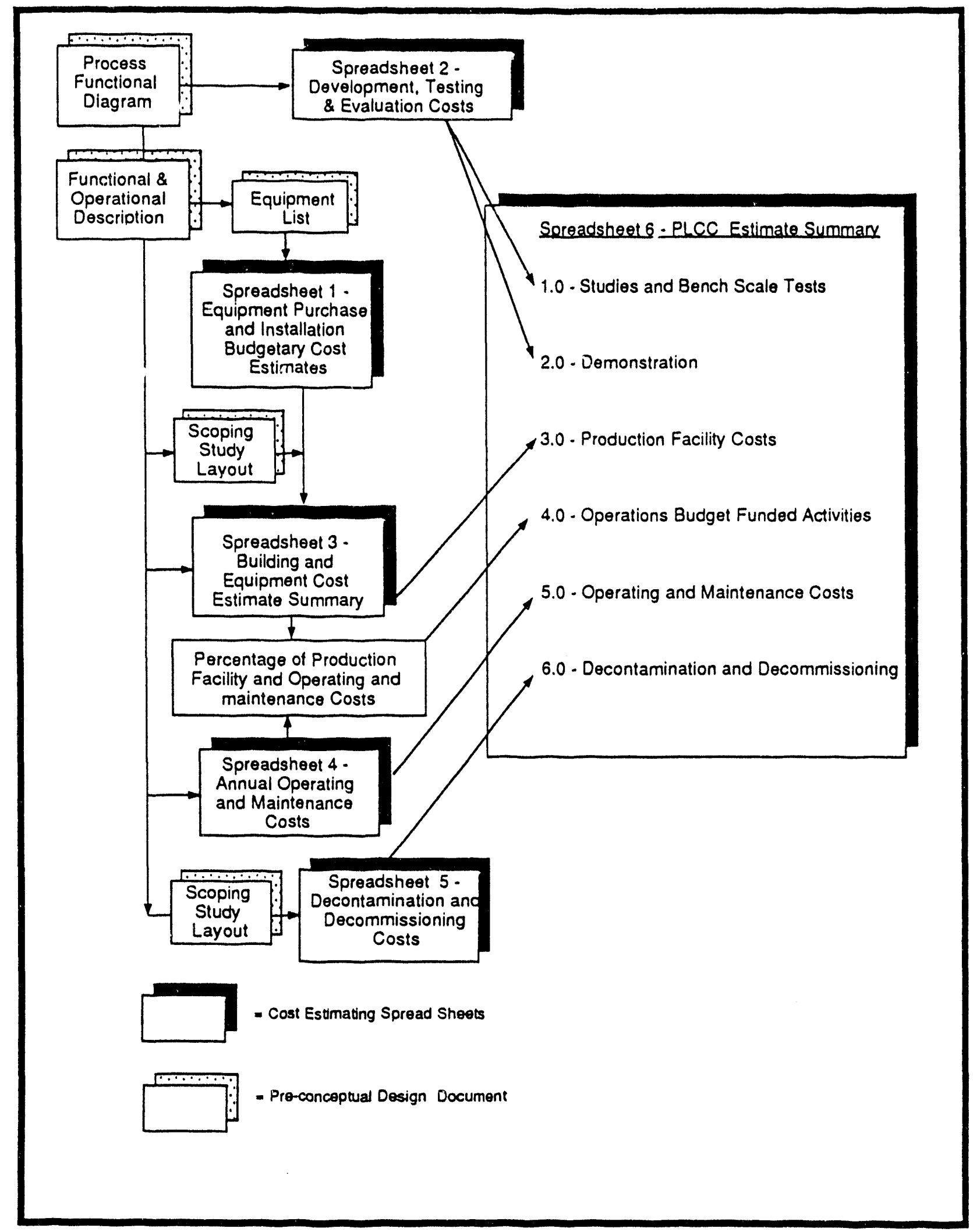

Figure 1-2. PLCC cost estimating steps. 
- Metal sizing/decontamination (cost module II).

The capacity of the large GTCC LLW vitritication facility is the same as the medium size LLW/MLLW vitrification facility presented in EG\&G Idaho report EGG-WTD-10443 (Feizollahi and Shropshire 1992a). The purpose of selecting the same capacity is to identify the difference in cost for treating the two waste streams. Accordingly, it is found that vitrification PLCC estimate for LLW/MLLW is $\$ 5.34 / \mathrm{hb}$ and GTCC LLW is $\$ 12.76 / \mathrm{b}$ of incoming waste throughput.

GTCC LLW can be stored in a facility similar to the concept developed for the SNF hardware and scrap metal storage facility (cost module $Z$ ) discussed in a report addressing costs for management of SNF waste stream (Feizollahi and Shropshire 1993a). Another concept discussed in this report is silo storage (cost module MM). A preconceptual design package and PLCC cost estimate for both storage concepts are included in this report.

Disposal options for GTCC LLW are (a) engineered shallow land disposal, (b) deep geological repository similar to Yucca Mountain Repository, and (c) intermediate depth disposal. For the engineered shallow land disposal option, data from modules $\mathrm{P}$ and $\mathrm{Q}$ (see Reference 1 ) have been repeated in this report. For the deep geological repository option, disposal cost data from Yucca Mountain Repository were obtained and are summarized in this report. For intermediate depth disposal, which has not been addressed in prior reports, a new preconceptual design package was prepared, and PLCC estimates were developed and are includec here.

\subsubsection{Facility Operation Assumption}

The PLCC estimates are based on the assumption that the operating life of all TSD facilities is 20 years. During this period, the facilities will operate 24 hours/day, 5 days/week, 240 days/year, and assumes $70 \%$ plant availability during operation. This is equivalent to 168 days/year, or 4032 hours/year of operation. In facilities with small capacities, where a three-shift operation is not justified, a single shift per day, or part-time shifts may be used. However, all mass flow rates given in this report are uniformly calculated based on 4.032 hours/year and 20 years of operation.

\subsubsection{Cost Estimating Method}

Data from waste inventory analysis defined baseline operation for two different facility sizes, small and large. Whenever possible, the baseline capacities were selected to be the same as an existing facility or a previous facility that had been estimated by the WMFCI task. This approach, referred to as "anchoring," provided a reference point that could be used as the basis for estimating the various cost components. Furthermore, anchoring facilitated comparison of the estimates in this report with either the actual costs incurred by an operating facility or estimates of facilities that are in an advanced design and construction stage.

b. In this report, "anchor" facilities denote reference facilities that are either in operation or in advarced design and construction stage. "Anchoring" denotes using technical data and capital, operating, and maintenance costs incurred by an anchor facility as a measuring stick in the development of the PLCC estimates. Before comparing costs from an anchor facility, they were adjusted to account for any differences in technical requirements and cost escalation. Construction Cost Trends manual published by the Bureau of Reclamation, United States Department of Interior was used as the basis for escalation data. 
Using the given capacities, a preconceptual design package for each facility was developed and used as the basis for PLCC cost estimates. Each preconceptual design package included a process functional diagram (PFD) with mass flow rates, a scoping study layout (SSL), and a summary functional and operational requirement (F\&OR). The PFD and SSL drawings were developed to the individual unit operations level. After unit operations were defined, major equipment lists and building configurations were established for each unit operation. The design packages utilized as much of the data from existing or planned $c$ immercial and DOE (anchor) facilities as possible. New designs were generated only if existing data were not available.

PLCC for each facility was divided into six components (see Figure 1-2), each of which were estimated separately. Costs for the first and second cost components (studies and bench scale tests, and demonstration) were obtained by estimating research manpower and equipment needs.

The third cost component (production facility construction costs) consists of two key subcomponents: equipment and building cost. Cost estimates for major equipment were obtained either from a similar facility, anchor facility, soliciting budgetary costs from the suppliers, or making engineering judgments. Building costs were estimated either by multiplying building unit costs by the space square footage allocated to each unit operation in the SSLs, or by developing building material and labor requirements, and multiplying them by the appropriate unit rates.

Once the equipment and building costs were estimated for each facility, they were totalled and multiplied by a percentage to allow for the construction contractor's indirect costs. The sum of the equipment, building and indirect costs were further multiplied by appropriate factors to allow for design, inspection, construction management, and project management costs. Allowances were also included for management reserve and contingencies.

The fourth cost component (operations budget funded activities) includes conceptual design, safety assurance, National Environmental Policy Act (NEPA) compliance efforts, and permitting, preparation for operation, and project management costs. The NEPA compliance efforts and permitting activities costs were estimated at \$6 million for a full NEPA, an environmental impact statement (EIS) process, and \$1 million for an environmental assessment (EA) process. All other subcomponents of the operations budget funded activities cost were estimated as a percentage of the construction cost.

The fifth cost component (operations and maintenance (O\&M)) consists of five subcomponents: operating labor, utilities, consumable materials, maintenance parts and equipment, and maintenance labor costs. The first three subcomponents were estimated based on analyzing the requirements of each facility at the unit operations level. The remaining two subcomponents were estimated as a percentage of the original equipment installed at the facility.

The sixth cost component (decontamination and decommissioning (D\&D) (facility closure)), was estimated by multiplying a D\&D unit rate by the facility square footage. For disposal facilities, long-term maintenance and monitoring costs were also added to the D\&D cost. The total facility PLCC estimates were obtained by adding the six cost components.

\subsection{Waste Management Scenario Costing Procedure}

To guide the DOE and its subcontractors in the use of this report, a procedure for developing PLCC estimates was established. It allows the user to easily project the overall cost of a given GTCC 
LLW management alternative. The procedure (Figure 1-3) is based on seven basic steps, summarized bclow:

1. Define the overall GTCC LLW management alternative.

2. Define parameters including type of waste, waste volumes, locations of waste, and combination of GTCC LLW management facilities.

3. Select the required treatment cost modules and. if appropriate, administration support and receiving and preparation and shipping cost modules. Obtain the corresponding PLCC estimates by selecting (from the cost/capacity graphs or tables in Sections 2 through 10) one of the cost modules closest to the required capacity.

4. Select the required storage cost modules and obtain the corresponding PLCC estimates by selecting (from cost/capacity graphs or tables in Sections 11 through 12) one of the cost modules closest to the required capacity.

5. Select the required disposal cost modules and, if applicable, front-end support module, and obtain the corresponding PLCC estimates by selecting (from cost/capacity graphs or tables in Sections 13, 14, 15, and 16 of the report) one of the cost modules closest to the required capacity. However, if a deep geological repository is required, refer to Section 17 where a unit rate cost estimate may be applied.

6. Calculate transportation costs using data given in Section 18 of this report.

7. Add Items 3 through 6 to yield the total PLCC estimates for the given waste management alternative.

A detailed description of this procedure is presented in Section 7.

\subsection{Cost Assessment Activities}

To the extent possible, major equipment costs in each cost module were compared with data from anchor facilities to establish a cost contidence level within the boundaries established for the PLCC estimates. Both the DOE and the commercial nuclear industry are now planning or operating similar facilities. These facilities were surveyed to obtain capacity, cost data, and other information needed to support the GTCC LLW cost data. Before using these costs, the data were adjusted to account for capacity differences and escalation.

Additional assessment activities included a review of applicable cost models that could be used to analyze and verify the cost estimates from this study. Methodology for this assessment is described in Section 1.6 of the Waste Management Facilities Cost Information Report (Feizollahi and Shropshire 1992a).

\subsection{Report Organization}

Section 1 contains background and summary information of the PLCC estimates. The cost estimating methodology, general assumptions, and basis used in developing PLCC estimates are presented in Appendix A. 


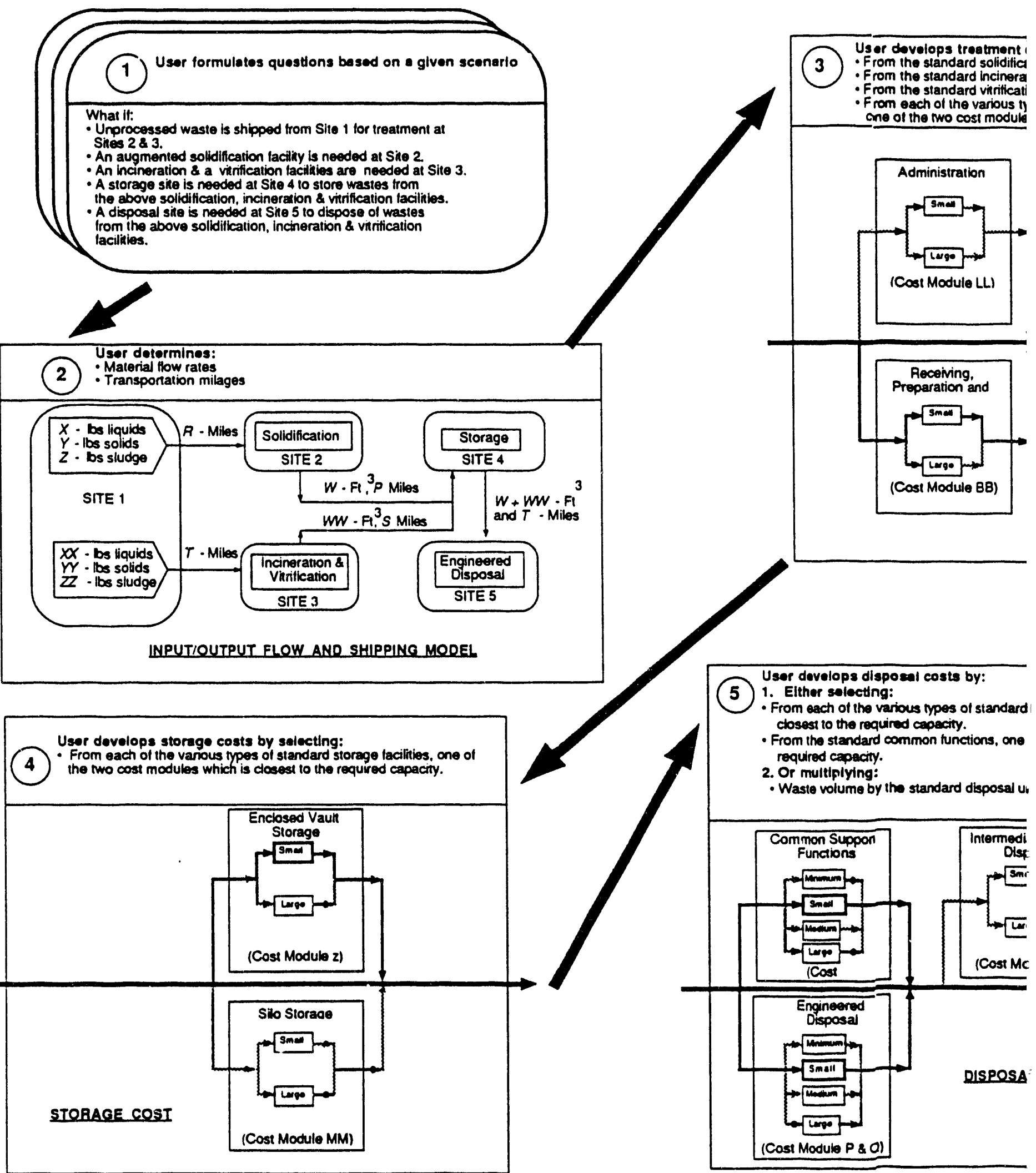

Figure 1-3. Procedure for developing GTCC LLW management PLCC estimates from the WMFCI report. 


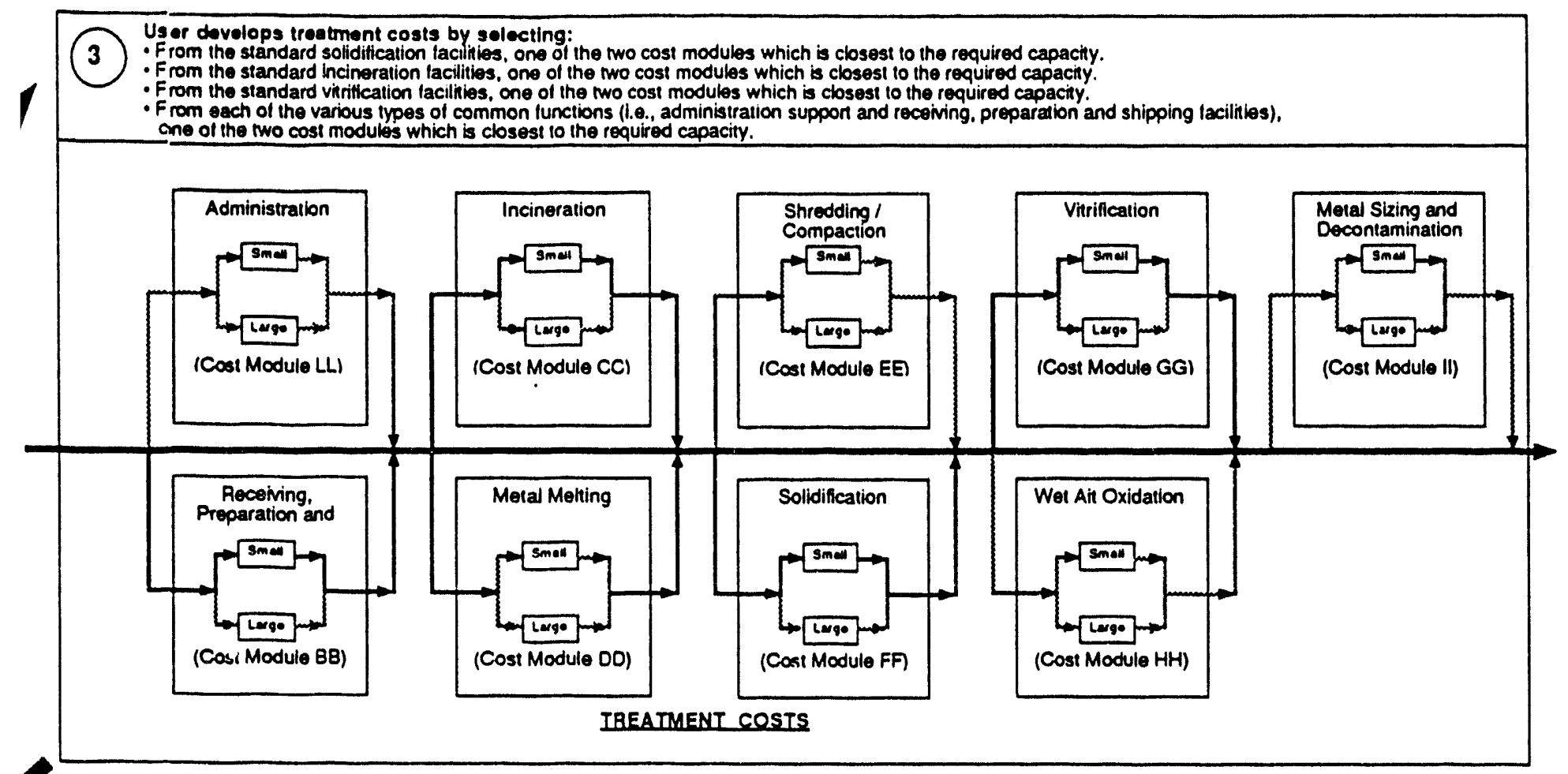

Jeer dovelops disposel costs by:

1. Elther solocting:

From each of the various types of standard disposal lacilities, one of the cost modules which is closest to the required capacity.

From the standard common functions, one of the two cost modules for which is closest to the

required capacity.

2. Or multiplying:

- Waste volume by the standard disposal unit rates.

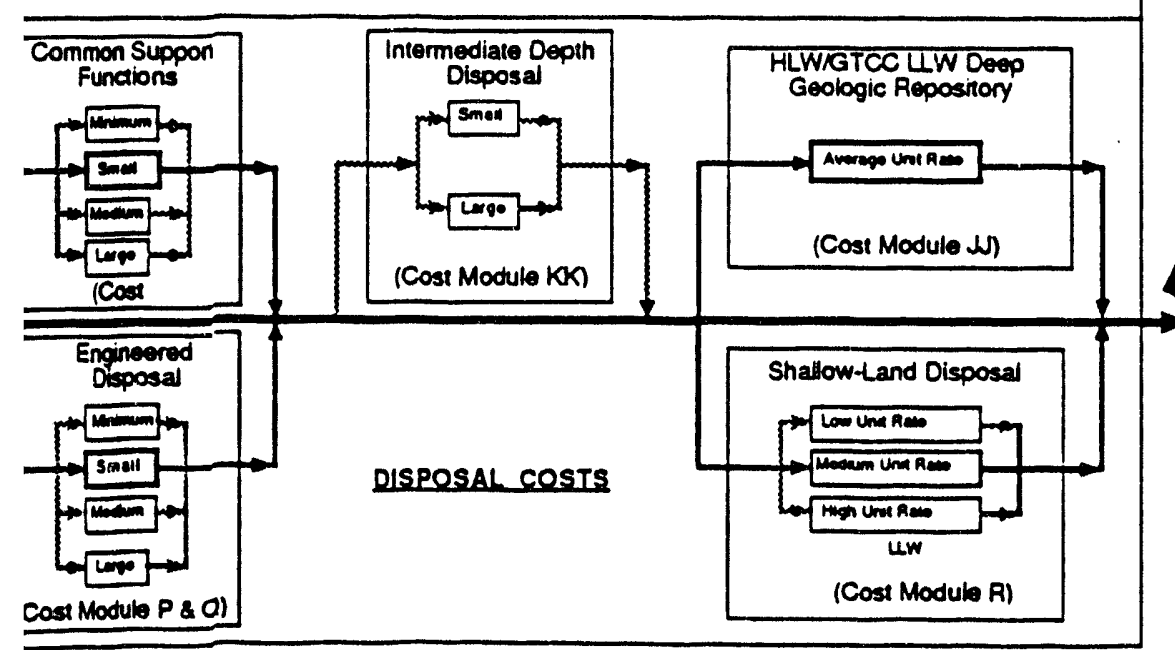

6 User develops transportation costs by multplying :

- Waste volumes by the standard transportation unit rates and the milage.

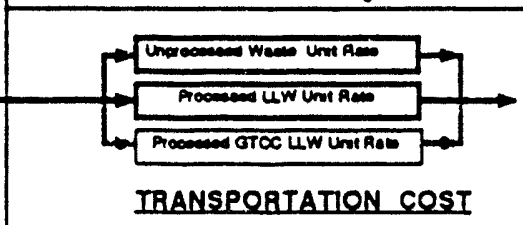

I the WMFCI report. 
Sections 2 through 17 summarize each treatment and disposal cost module. Sections 2 through 17 only describe activities and assumptions that apply to the specific process in each section. Additional general assumptions and cost bascs that apply to most or all cost modules are included in Appendix A.

Section 18 presents procedures for costing various waste management scenarios. PLCC estimate backup information for this report is included in Waste Management Facility Cost Information Estimating Data for Greater-Than-Class C and DOE Equivalent Special Case Waste, EGG-WM-10709 (Fcizollahi and Shropshire 1993b).

\subsection{Limitations}

Section 18 and Appendix A must be consulted regarding limitations and qualifications that apply to development of PLCC estimates for various waste management options. To apply cost data from this report, at a minimum, the reader must ensure that the administration support facilities is incorporated. Administration support facility cost module includes PLCC associated with administration, environmental and health compliance, security, and related activities.

Data from PLCC estimate histograms given in Sections 2 through 17 should be extrapolated with caution (the reader should note that this task developed estimates only for those capacities shown as the estimate points on the histograms). Most of the cost components (such as facility capital and operating labor costs) do not change significantly within a given capacity range. Only a minor portion of the cost components (i.e., power consumption, consumable materials, and maintenance costs) has a direct relationship with the quantity of waste processed by the facility. Figure 1.4 and Section 1.8 of the Waste Management Facilities Cost Information Report (Feizollahi and Shropshire 1992a) should be consulted before using extrapolated data. 


\section{ADMINISTRATION SUPPORT FACILITY (COST MODULE LL)}

\subsection{Basic Information}

The administration support facility includes all administrative, laboratory, site access, and security buildings required for the GTCC LLW waste management facilities. The administration support facility is essentially the same for all treatment cost modules. This facility should be used whenever a new GTCC LLW waste treatment complex is planned.

\subsection{Technical Basis and Requirements}

\subsubsection{Functional and Operation Description}

The GTCC LLW administration support facility provides all support functions needed to manage the operation of a GTCC LLW waste treatment complex. These functions include security, personnel decontamination (radioactive and hazardous), housekeeping maintenance of nonradioactive areas/equipment, health physics, radiation badges, facility access control, sanitary facilities, work control, personnel support, internal and external (public relations) communications, spill or emergency response provisions (hazardous and radioactive), environmental regulatory reporting, and records management. An analytical laboratory for general environmental field and mixed waste sampling is included in the facility.

\subsubsection{Facility Integration}

This facility interfaces with site communication and alarm systems including telephone, evacuation fire, security alarm, and public address systems. There are a number of consumable items for the office and laboratory which must be purchased. The facility serves as the support center for treatment facilities.

\subsection{Cost Bases, Assumptions, Assessments}

General cost bases and assumptions are given in Appendix A. Facility-specific items are discussed below:

- Major equipment capital cost item is laboratory analytical equipment. Analytical instruments and components needed for an environmental analysis and mixed waste laboratory are estimated to be $\$ 1,000,000$ and $\$ 1,500,000$ for a small and large facility respectively. Estimates are based on quotes obtained by Eberline Corp.

- Estimated operations staff is shown in Table 2-1.

- Office space is based on $250 \mathrm{ft}^{2}$ per person, and includes corridors, support areas, and other non-office space.

- An allowance of $\$ 7,000$ per employee has been included for the purchase of office furnishings including personal computers. This cost does not include a mainframe computer estimated at $\$ 250,000$ for the small facility and $\$ 500,000$ for the large facility. 
Table 2-1. Estimated operating staff for GTCC LLW administration support facility (cost module LL).

Unit

Operation

A-1

A-2

$-2$
Description

Administration Office:

Accountant

Secretarial/Clerk

Document Control

Manager

Technical Personnel

Communications

Environmental Manager

Oper. Support/Mgmnt.

Q.C. Technicians

Security Guard

Health Physics Technicians

Testing Laboratory

Total

$\begin{array}{ll}\text { Small } & \text { Large } \\ \text { (FTE) } & \text { (FTE) }\end{array}$

$\begin{array}{ll}1 & 2 \\ 2 & 4 \\ 2 & 3 \\ 2 & 4 \\ 1 & 3 \\ 1 & 1 \\ 1 & 3 \\ 1 & 3 \\ 1 & 3 \\ 4 & 7 \\ 4 & 6\end{array}$

$\begin{array}{ll}7 & 8\end{array}$

27

- The cost of purchasing the laboratory test equipment is based on a list price provided by Eberline Corp.

- Small and large facility capacities and unit costs are shown in Table 2-2.

- Design costs are $8 \%$ of construction costs.

\subsection{Cost Summaries}

Cost summary for the administration support facility is shown in Table 2-3. A histogram of cost vs. capacity is shown in Figure 2-1. 
Table 2-2. Capacity and unit cost for administration support facility (cost module LL).

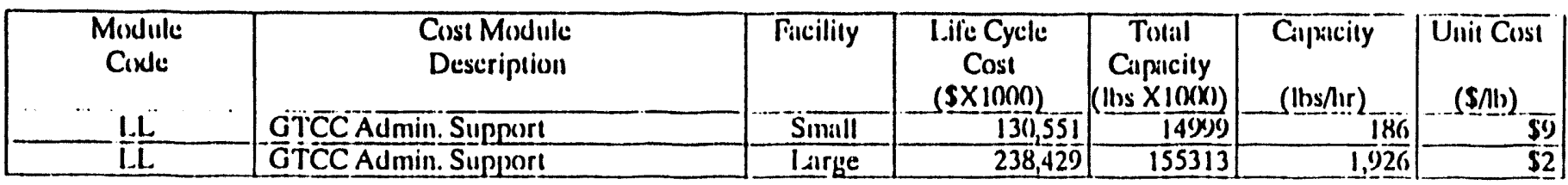


Table 2-3. PLCC estimate summary for GTCC LLW administration support facility (cost modulc LL).

\begin{tabular}{ccc}
\hline Cost & Cost ltems & Cost \\
$(S \times 1000)$ & Iarge \\
\hline
\end{tabular}

12 Equipmeat costs

13 losullation costs

1.4 Project managemeat before tille I ( $10 \%$ of 1.1 through 1.3)

is Cosungency

Subcotal 1.0

Demonstration conls

2.1 Manpower cosls duriag de monstration

22 Design cost

23 Inspection cost

( $30 \%$ or 25 )

2.4 Project managemeat

( $7 \%$ or 25$)$

is Coustrucriou cost

( $10 \%$ o( 2.5)

\subsubsection{Building suructure cosss \\ 252 Equipmeat const}

253 lodirect ( $29 \%$ or 25.1 \& 2.5.2)

Subtotal or 25

2.6 Constructuon managemeat costs ( $17 \%$ of 25$)$

2.7 Managemeal Reserve (10\% ol 2.5 )

2.8 Conungency $\quad(25 \%$ ol 2.1 urrough 2.7$)$

Sublotal 2.0

Production tacility construction conss

3.1 Desiga cost

( $8 \%$ o( 3.4)

32 Inspection cost

( $3 \%$ or 3.4 )

3.3 Project managemeat

( $10 \%$ or 3.4)

$\begin{array}{ll}\text { so } & \text { so } \\ \text { so } & \text { so } \\ \text { so } & \text { so } \\ \text { so } & \text { so } \\ \text { so } & \text { so } \\ \text { so } & \text { so }\end{array}$

3.4 Construction cont

$$
\begin{array}{ll}
3.4 .1 & \text { Building structure coats } \\
3.42 & \text { Equipmeat costs } \\
3.43 & \text { Indirect }
\end{array}
$$

( $29 \%$ o( $3.4 .1 \& 3.4 .2)$

Sublotal ol 3.4

35 Cosatruction managemeat

3.6 Managemeat Reserve

$(17 \%$ of 3.4$)$

3.7 Continzeacy

( $10 \%$ or 3.4$)$

( $25 \%$ or 3.1 through 3.5 )

Sublotal 3.0

Operacions Budget Fuaded Acrivicies (See SecL 7 )

Operacions Budget
4.1 Conceprual deaigo

( $15 \%$ o( 3.0)

$\$ 2$ Salery asourace

( $1 \%$ o( 3.0)

43 NEPA permitting (\$ 6 Mill for EIS. SI Mill for EA)

4.4 Preparauon for operacioas $\quad(100 \%$ of 5.0$)$

45 Project Management

( $10 \%$ of 4.1 through 4.4 )

Subtotal 4.0

Toul Initial Cost $(1.02 .0 .3 .0 \& 4.0)$

Operatiag asd maialainesce costs (Loading / Ualoading Period)

S.1 Ausual operating costs

52 Aoaual unility coats

5.3 Anoual material conts

S.t Araval maincainence conts

5.5 Contingency

5.6 Sublotal 5.0

5.7 Total 20 year $O \&$ M cost (20 times Subtotal S.0) 


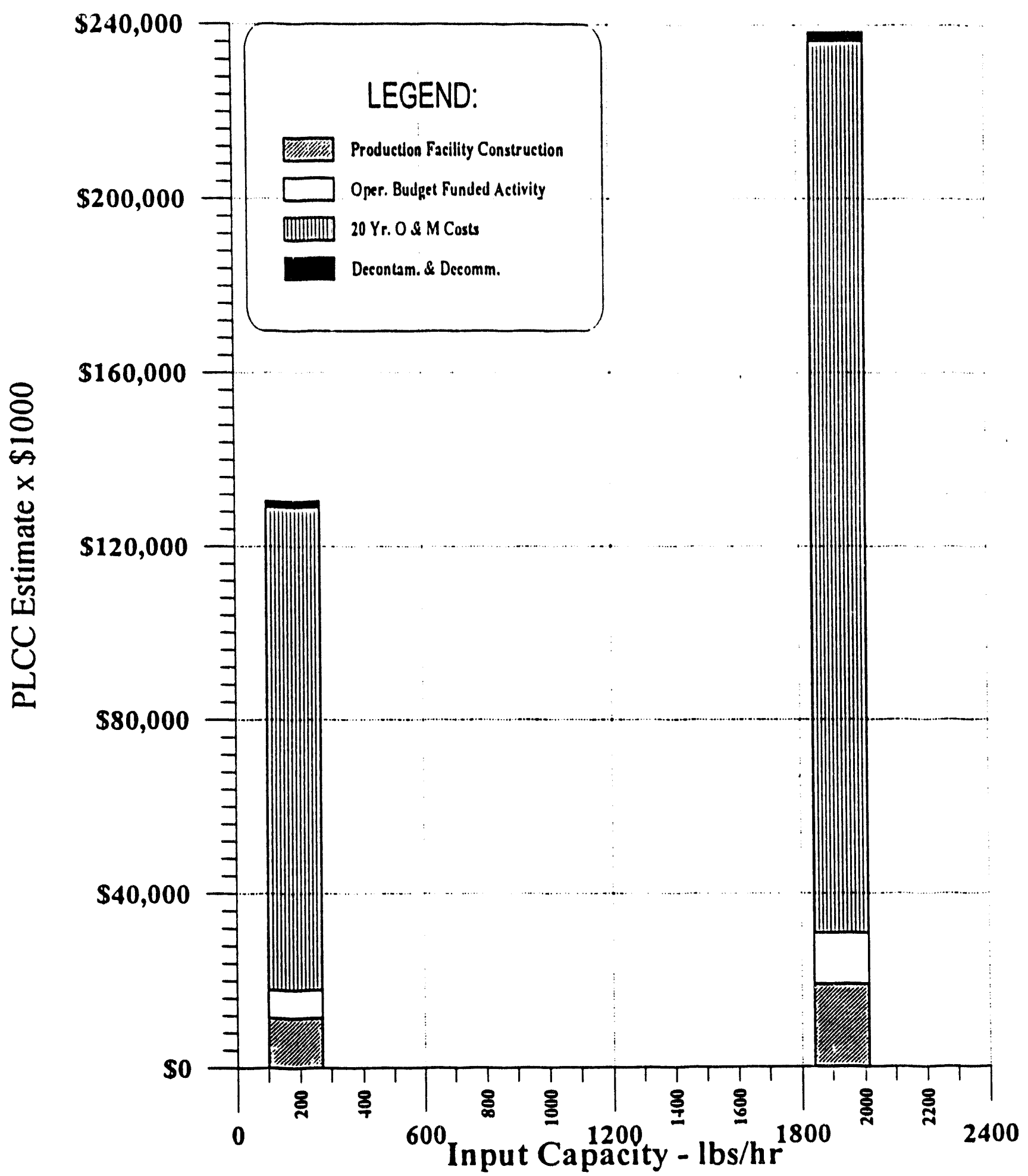

Figure 2-1. Cost versus capacity histogram for GTCC LLW administration support facility (cost module LL). 


\section{TREATMENT RECEIVING, PREPARATION, AND SHIPPING FACILITY (COST MODULE BB)}

\subsection{Basic Information}

The receiving, preparation, and shipping facility (shown in Figures $3-1$ and 3-2) is the first part of an overall complex needed for treatment, storage, and disposal of GTCC LLW. It provides the front-end and back-end functions and is intended to be joined with the waste treatment facilities (cost modules CC, DD, EE, FF, GG, HH, and II). It should be used in conjunction with the treatment facilities whenever facilities and equipment to perform the front-end and back-end functions are not available in a candidate location.

The facility is designed to remotcly unload, store, inspect, open, and sort the incoming (untreated) waste and feed it to the treatment facilities. It also receives, stores, inspects, certifies and ships the outgoing (treated) waste. When the incoming waste is not compatible with the :-eatment capabilities of the given processing techniques, it is treated by a special waste packaging unit operation which is included in the receiving, preparation and shipping facility. The facility also has capability to size reduce, package and return the empty waste containers for treatment, or disposal.

The functions of the receiving, preparation and shipping facility are accomplished by 13 major unit operations including: load/unload, stage and store, inspect and assay, decap containers, sort. package discarded containers, and special waste packaging. A process functional diagram of the receiving preparation and shipping facility is shown in Figure 3-3.

\subsection{Technicar Basis and Assumptions}

\subsubsection{Functional and Operational Description}

Transportation vehicles mounted with shipping casks are used to ship GTCC LLW containers from the generators to the receiving, preparation and shipping facility. These vehicles are not included in the cost module. A loading and unloading unit operation equipped with a high capacity bridge crane with an auxiliary hoist receives. loads, and unloads containers to and from shielded transportation casks, including LLW and spent nuclear fuel casks, mounted on flat-bed trailers. Containers brought in large overpacks (e.g.. Transuranic Package Transporter II [TRUPACT-II]) can also be unloaded. The loading and unloading unit operation removes containers from the shipping cask and places them in a staging and storage area.

The staging and storage unit operation stores the containers and moves them within the unloading, staging, and surge storage areas. In addition, the unit operation transfers containers to and from the various interfacing unit operations. The surge and storage area is large enough to allow maneuvering of the containers during the staging operations and provide sufficient surge storage capacity to meet the desired operational reliability.

-

An assay and inspect unit operation determines radioactivity, physical properties, and other parameters that are necessary to categorize the containerized waste in accordance with the criteria established for the processing unit operations. In addition, the unit operation can sample the waste in the containers as needed for characterization of the waste according to the Resources 
$232^{\prime} \cdot 0$

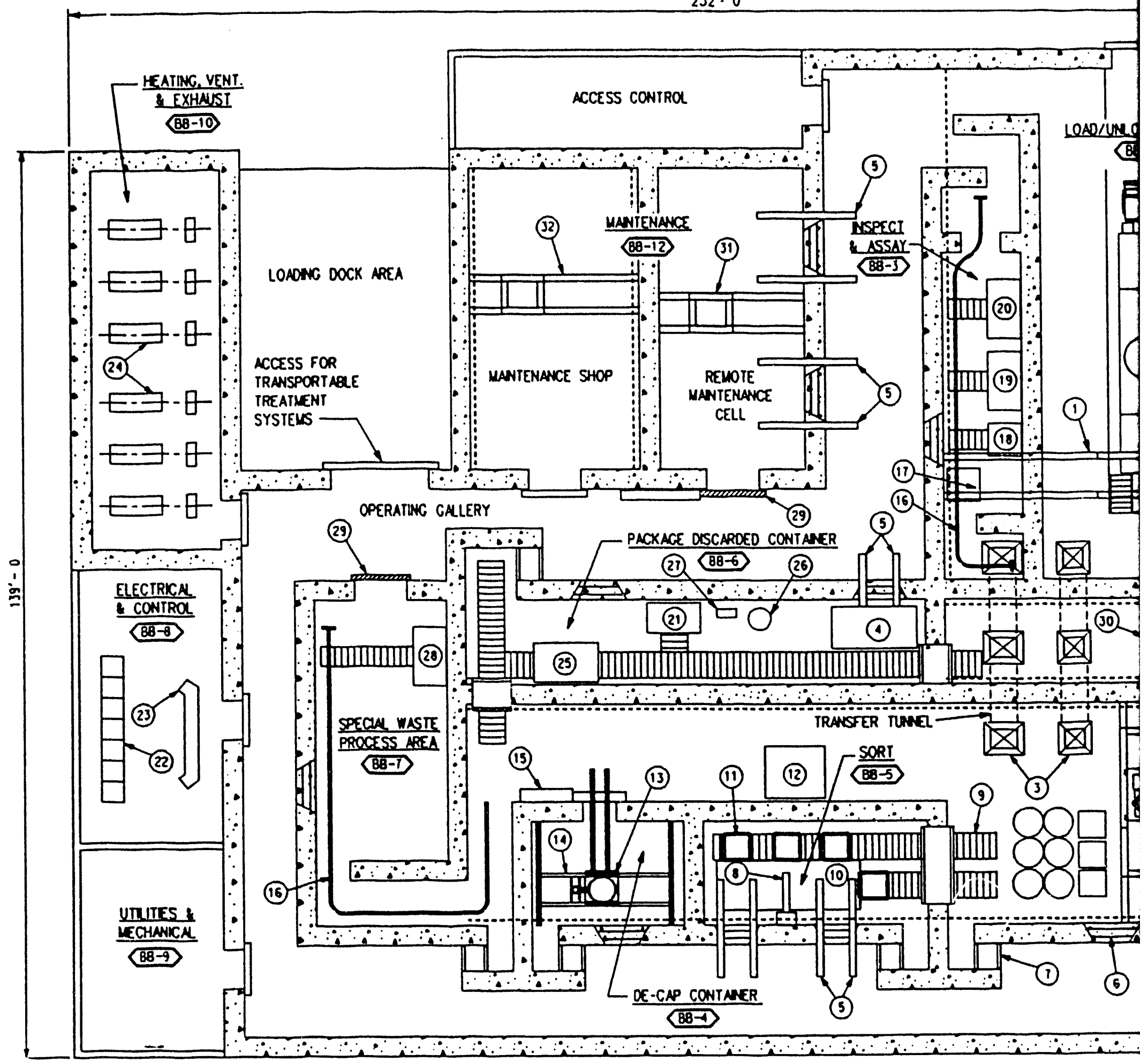

RECEIVING, PREPARATION \& SHIPPING (COST MODULE BB) LARGE FACILITY FLOOR PLAN

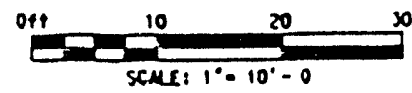

Figure 3-1. GTCC LLW receiving, preparation, and shipping large facility floor plan (cost module BB). 


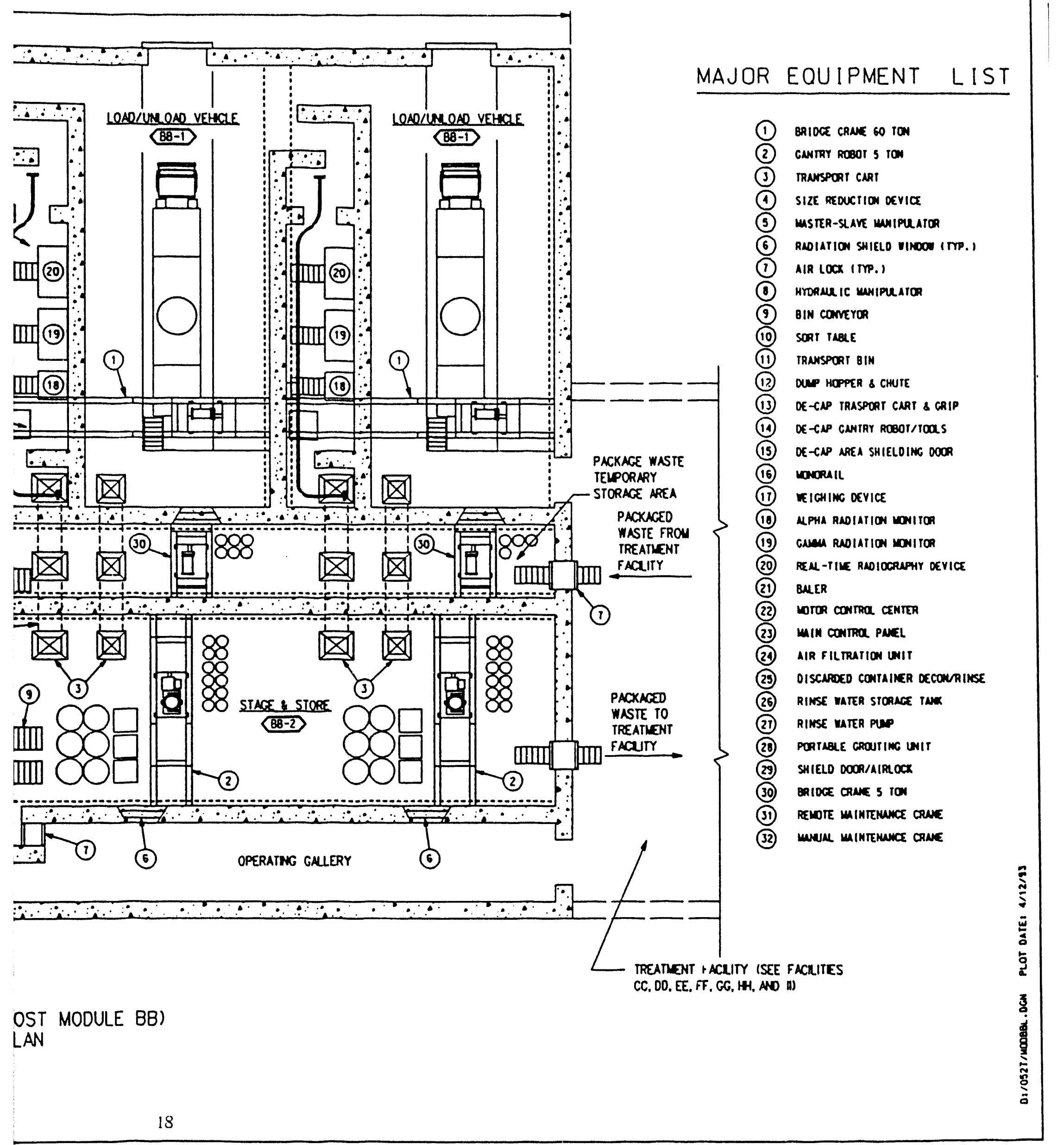




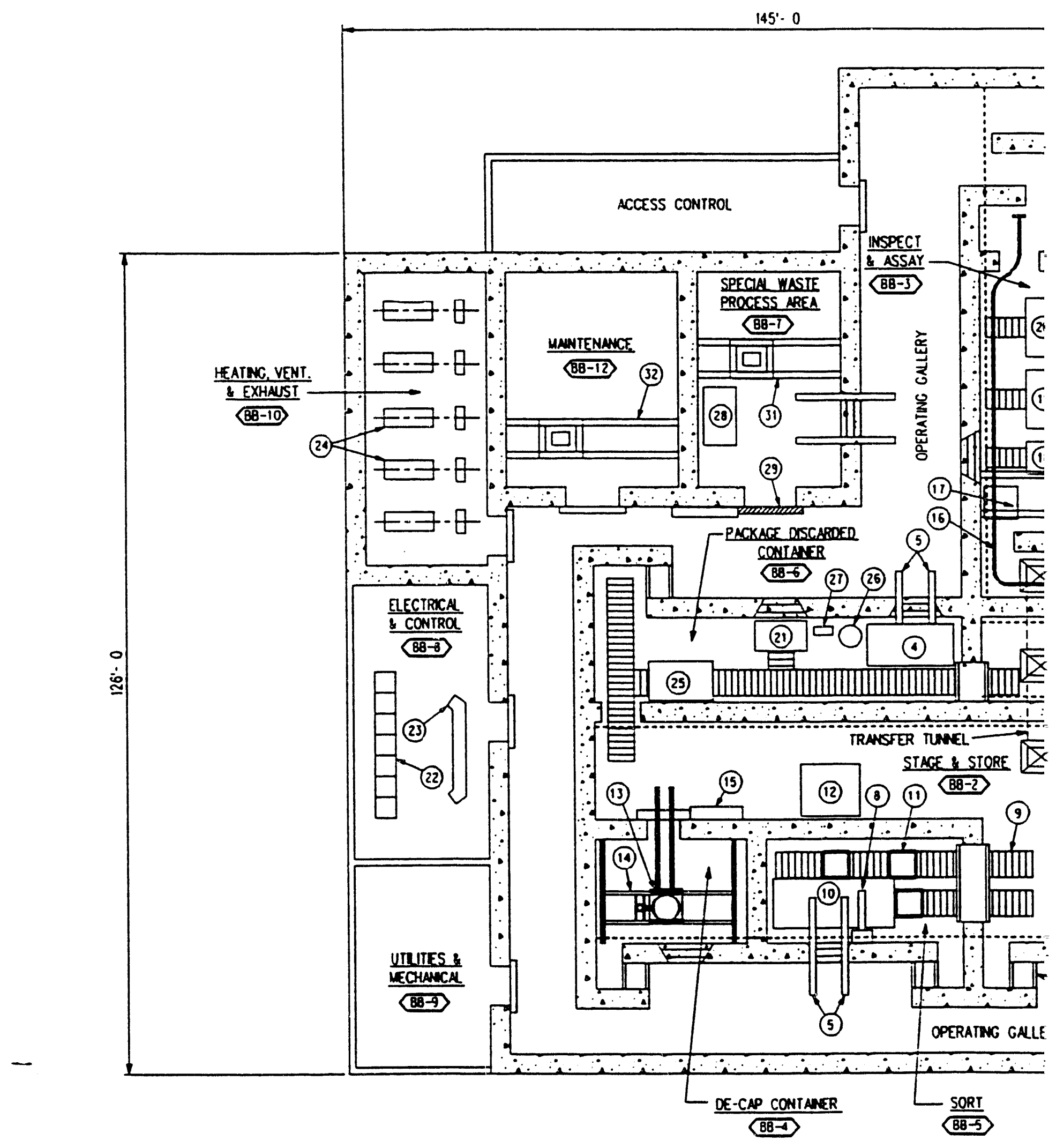

RECEIVING, PREPARATION \& SHIPPING ICOST A SMALL FACILITY FLOOR PLAN

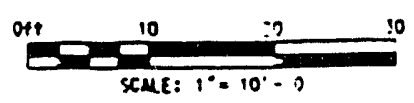

Figure 3-2. GTCC LLW receiving, preparation, and shipping small facility floor plan (cost module BB). 


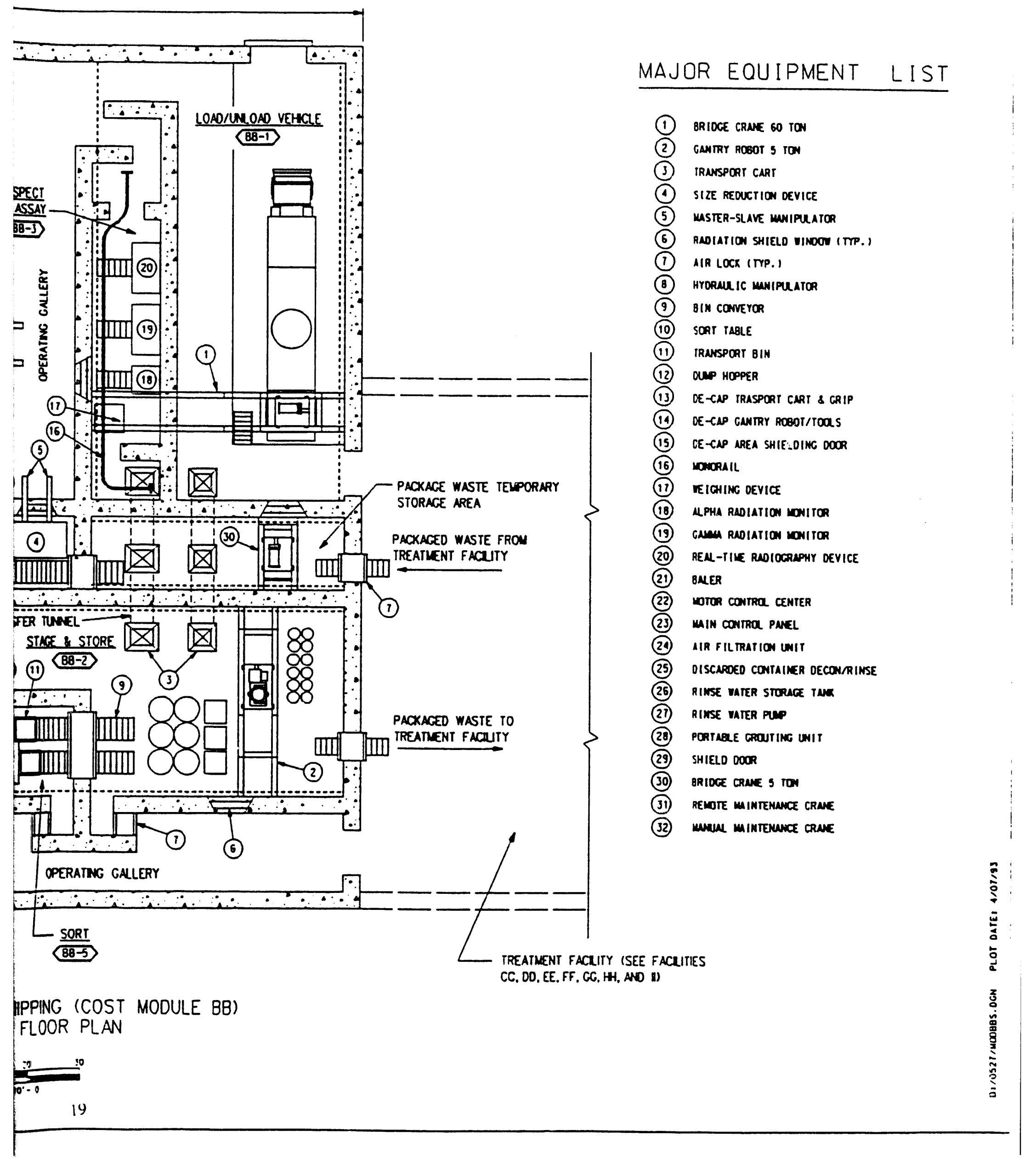




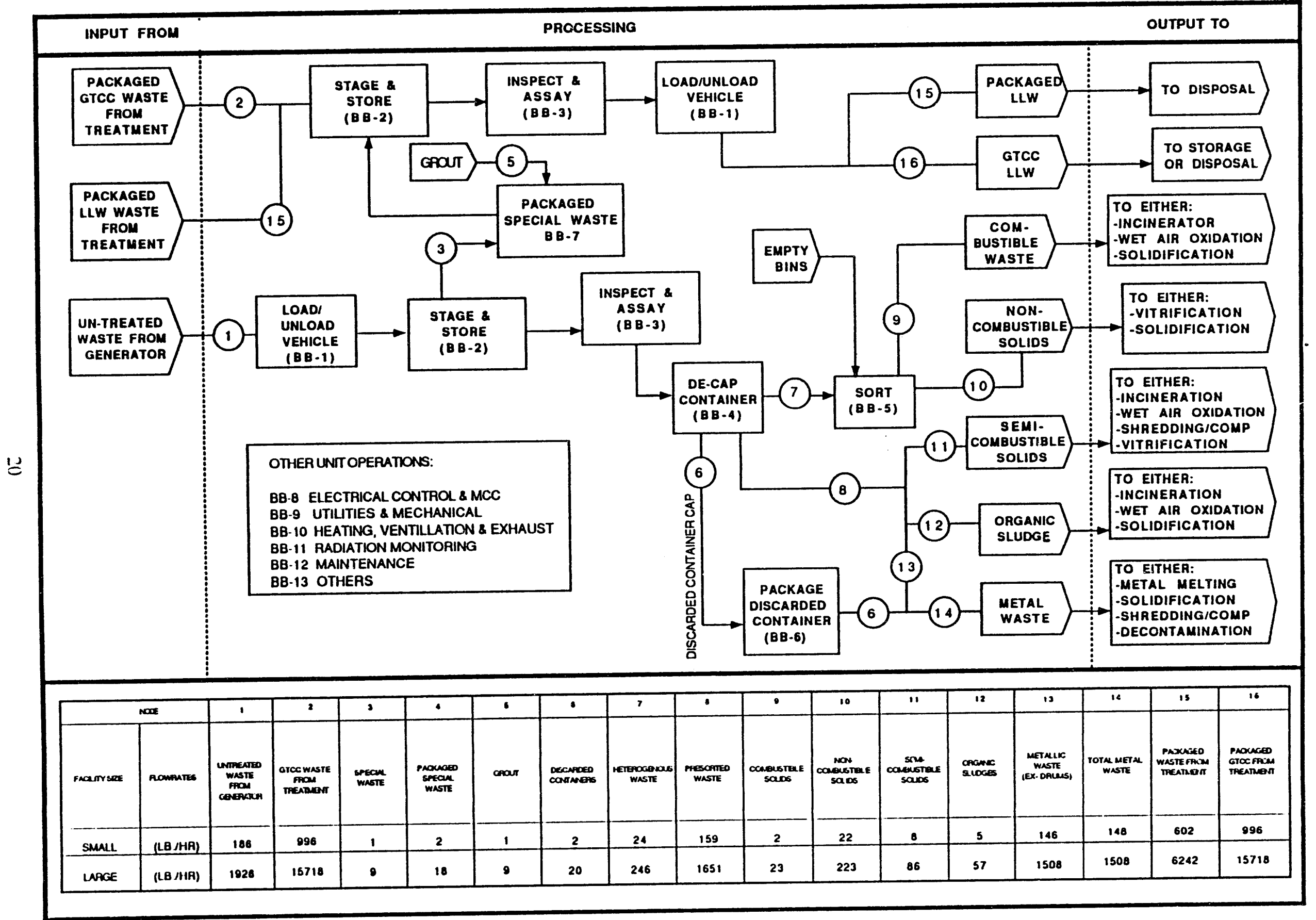

Figure 3-3. Process functional diagram for GTCC LLW receiving, preparation, and shipping facility (cost module BB). 
Conservation and Recovery Act (RCRA) requirements. Samples are sent for analysis by laboratory (located in cost module LL). Assay functions can be accomplished by various devices, such as passive/active neutron (PAN) counting and Segmented Gamma Scan (SGS) instruments.

After the containers are assayed, they are weighed and measured to determine waste density. Contents (such as metals, paper, glass, sludge, gas cylinders, and liquids) are determined by nondestructive examination. At a minimum, each container is examined using a nondestructive assay equipped with a real-time radiography (RTR) device. Ultrasonic devices are also used. After examination, each container is labeled, and the properties of its contents are logged and entered into a computerized database.

Containers holding waste acceptable by the treatment unit operation are sent to a decap unit operation which is described below. Containers holding waste unacceptable by the treatment facilities are sent to a special waste packaging unit operation where special processing techniques are devised and constructed or leased on a case-by-case basis. Typical waste that can be treated by special waste packaging unit operation is the sealed sources waste stream. This waste can be placed in a larger overpack and filled with a macro-encapsulation agent such as Portland cement.

The GTCC LLW container decap, dumping, and sorting operations are accomplished remotely by manipulators and robots housed in a cubicle that has a controlled environment and multiple barriers. Adequate hoods and supporting ventilation minimize the spread of dust and contamination. All operations are accomplished in an alpha cell where containers enter the cell through airlock doors. Equipment maintenance is accomplished manually in a controlled environment. In addition, the equipment can be pulled out and decontaminated before performing maintenance.

After the waste containers enter the controlled cubicle environment through airlock doors, they are grouped according to two categories: those that must only be opened and dumped, and those that require open, dump, and sort operations. After container caps are removed, the waste in the containers of the first category are dumped into bins that directly transport it to the treatment facilities.

The waste in the containers that are designated for segregation is dumped onto a sorting station, which removes bulk metals, noncombustibles, semicombustibles, combustibles, and special wastes. ${ }^{c}$ Various sorting technologies, such as robotics assisted sort tables, vibratory screens, and air classifiers, may be used in the sorting station. Any liquid spilled during sorting is collected and sent to the treatment facilities for processing. The sorted waste material is placed into transfer bins and transferred to the treatment facilities.

The facility also includes a discarded container packaging unit operation. In this unit operation both metallic and nonmetallic containers are cut into smaller pieces and are either placed in drums and sent for offsite disposal, or placed in bins and sent for treatment by one of the treatment facilities (e.g., solidification, metal melting, or shredding and compaction). As an alternative, the unit operation can wash and decontaminate the containers and return them for $r$ use.

Another function of the receiving, preparation and shipping facility is shipping and certification of packaged waste received from the treatment facilities (cost modules CC, DD, EE, FF, GG, HH,

c. Special wastes are those materials that are not compatible with the routine processing techniques provided in the treatment facilities (e.g., $\mathrm{Hg}$ ). After identification and removal, special wastes are treated by special systems including transportable or leased units provided on a case-by-case basis. 
and II). In a typical operation, packaged waste containers arrive from treatment facilities on conveyors, carts or other transport devices. Containers are removed from the transport devices and placed in the staging area. The containers are then remotely examined, tagged, logged, recorded and sent to the assay and inspect unit operation. This unit operation examines the containers by radio-assay devices to allow both alpha and gamma radioactivity classification in accordance with the transportation, storage and disposal criteria. Next, the containers are weighed and measured to determine waste density. The existence of materials restricted by transportation, storage, and disposal is determined by nondestructive examinations such as ultrasonic instruments or a RTR device. After examination, each container is labeled and the properties are logged and recorded into a computerized database. The containers are then moved to a temporary storage area until it is ready for shipment to a long-term storage or disposal facility. When ready, the loading and unloading unit operation transfers the container onto shielded casks mounted on flat-bed trailers. Containers can also be loaded into large transportation overpacks (e.g., TRUPACT-II). Before leaving the facility, the trailer and vehicle are inspected and certified according to the DOE and U.S. Department of Transportation (DOT) requirements and regulations.

The major secondary waste from this facility is contaminated air generated during the handling operations. This air is collected by the ventilation system, filtered by high efficiency particulate air (HEPA) filters, monitored, and discharged to the atmosphere.

\subsubsection{Facility Integration}

In addition to general interfaces for all facilities, input interfaces to the receiving, preparation and shipping facility are waste (untreated) containers from storage or generator facilities, packaged waste (treated) from the treatment facilities (cost modules CC, DD, EE, FF, GG, HH, and II), and discarded containers from the treatment facilities. The facility output includes waste that is sorted according to the treatment requirements; discarded containers that are size reduced and packaged for reuse, treatment, or disposal; and treated waste which is placed in shipping vehicles going to disposal or long-term storage facilities. The facility secondary waste is treated air discharged from the HEPA filtration units. The facility consumables, including personal protective equipment, are purchased.

\subsection{Cost Bases, Assumptions, and Assessments}

The general bases and assumptions for the cost estimate are presented in Appendix A. Facilityspecific items are discussed below:

- Major equipment capital cost items for this facility include an alpha and assay system, a RTR unit, 60-ton bridge crane, container decap system, size reduction device, masterslave manipulator, and gantry robot.

- Estimated operating staff is shown below in Table 3-1.

- Al major equipment costs are based on vendor quotations. The inspection and assay units are based on conceptual designs and cost estimates for a radiological and hazardous material measurement system (RHMMS) provided by EG\&G. Budget estimate for inspection and assay system is $\$ 2$ million. 
Table 3-1. Estimated operating staff for GTCC LLW receiving, preparation, and shipping facility (cost module BB).

\begin{tabular}{|c|c|c|c|}
\hline Unit operation & Description & Small & Large \\
\hline BB-1 & Load and Unload Vehicle & 3 & 6 \\
\hline BB-2 & Stage \& Store & 3 & 6 \\
\hline BB-3 & Inspect \& Assay & 3 & 10 \\
\hline BB-4 & Decap Container & 2 & 6 \\
\hline BB-5 & Sort & 2 & 6 \\
\hline BB-6 & Package Discarded Containers & 0.5 & 2 \\
\hline BB-7 & Packaged Special Waste & 0.2 & 1 \\
\hline BB-8 & Electrical \& Control & 0.2 & 1 \\
\hline BB-9 & Utilities \& Mechanical & 0.3 & 1 \\
\hline BB-10 & Heating \& Ventilation & 0.3 & 1 \\
\hline BB-11 & Radiation Monitoring & 1 & 3 \\
\hline BB-12 & Maintenance & ? & a \\
\hline \multirow[t]{2}{*}{ BB-13 } & Others & 0 & $\underline{0}$ \\
\hline & Total & 15 & 43 \\
\hline & & & \\
\hline
\end{tabular}


- Small and large facility capacities and unit costs are shown in Table 3-2.

- The receiving, preparation, and shipping facility is common to all treatment facilities. Therefore, the NEPA permitting cost is included with treatment modules.

\subsection{Cost Summaries}

Cost summaries for receiving and inspection are shown in Table 3-3. A histogram of cost versus capacity is given in Figure 3-4. 
Table 3-2. Capacities and unit costs for GTCC LLW receiving, preparation, and shipping facility (cost module BB).

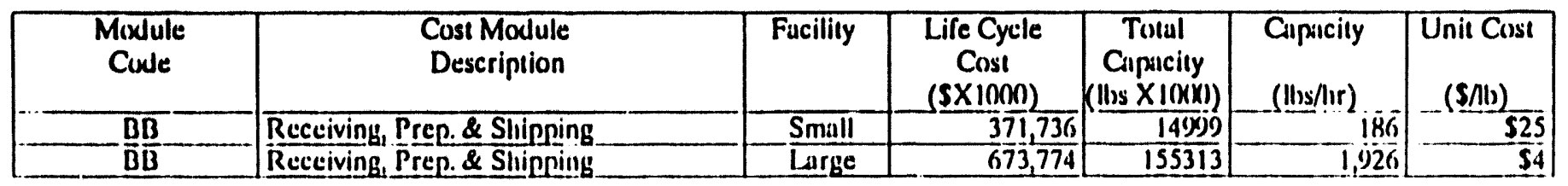


Table 3-3. PLCC estimate summary for GTCC LLW receiving, preparation, and shipping facility (cost modulc BB).

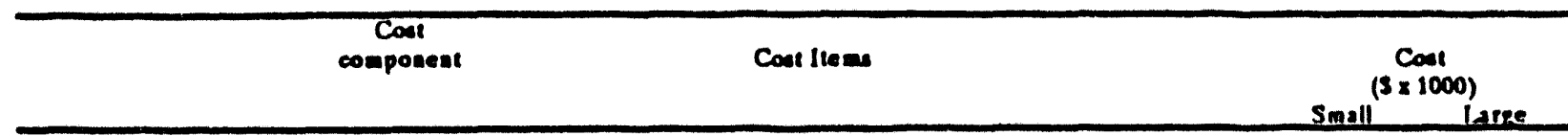

Studies and beach scale test costs

1.1 Manpower costs dunag research

12 Equipmeat costs

13 lostallation costs

1.t Project managemeat before title I) (10\% of 1.1 through 13)

is Contugency

( 25 5. of 1.1 (brough 1.4$)$

Subtotal 1.0

2.0 Demoestration costs

2.1 Manopwer costs during de moastration

21 Desiga cost

23 Inspection cost

2.t Project managemeat

25 Construction cost

25.1
252
253

Buildiag structure cost

Equipmeal costs

Indirect

$(29 \%$ of 25.18252$)$

Subtotal of 2.5

2.6 Construction managemeat costs

2.7 Managemeat Reserve

2.8 Contiazeacy

( $17 \%$ of 25$)$

( $30 \%$ of 25$)$

( $7 \%$ of 25$)$

( $10 \%$ of 25$)$

Subtotal 2.0

( $10 \%$ o( 25 )

( 259 of 2.1 (brough 2.7)

Production faciliny construction costs

3.1 Desiga cost

32 Inspection cost

3.3 Project masagemeat

3.t Construction cost

3.4 .1

$3 .+3$

Subtotal of 3.4

35 Construction managemeat

Buidding structure costs

Equipmeat costs

Iadirect

( $29 \%$ of $3.4 .1 \times 3.42)$

$(18 \%$ o( 3.4)

( $7 \%$ o( 3.4)

( $10 \%$ of 3.4$)$

3.6 Masagemeat Reserve

$17 \%$ of 3.4$)$

( $10 \%$ of 3.4 )

3.7 Contlageacy

( $25 \%$ of 3.1 through 3.5 )

Subtotal 3.0

Operations Budget Fuaded Activities (See Sect. 7 )

Operatious Budget

is $\%$ of 3.0$)$

42 Safery assura nce

$\$ 3$ NEPA permitting (S 6 Mill for EIS. S1 Mill tor EA)

4.4 Preparation for operations

$1 \% 0$ o( 3.0)

+5 Project Masage meat

$100 \%$ of 5.0$)$

Subtotal 4.0

Toul Initial Cost $(1.02 .03 .0 \&+.0)$

( $10 \%$ of 4.1 through 4.4 )

$\begin{array}{rr}S 300 & \$ 300 \\ 50 & 50 \\ 50 & 50 \\ \$ 30 & 530 \\ 583 & \$ 83 \\ S 413 & \$ 113\end{array}$

Operating and maincainence costs (Loading/ Unloadiag Period)

S.1 Annual operatiag costs

52 Anaual utility coses

S3 Anaual waterial costs

S.4 Anaual mainuineace costs

5.5 Contingeacy

( $25 \%$ of S.! 2rough S.4)

S.6 Subtoral 5.0

.

5.7 Total 20 year $O$ a $M$ cose (20 times Sublotal 5.0 )

\section{s23rs}

Sists

so

59.529

51.339

514.727

$\$ 171.892$

$\mathbf{5 3 . 8 3 5}$

52.557

518.909

S2530

$\mathbf{5 2 7 . 8 3 1}$

5286330

$\mathbf{5 . 0 2 0}$

51,906

59529

5190,580

59264

$\mathbf{5 3 7 1 , 7 3 6}$ 


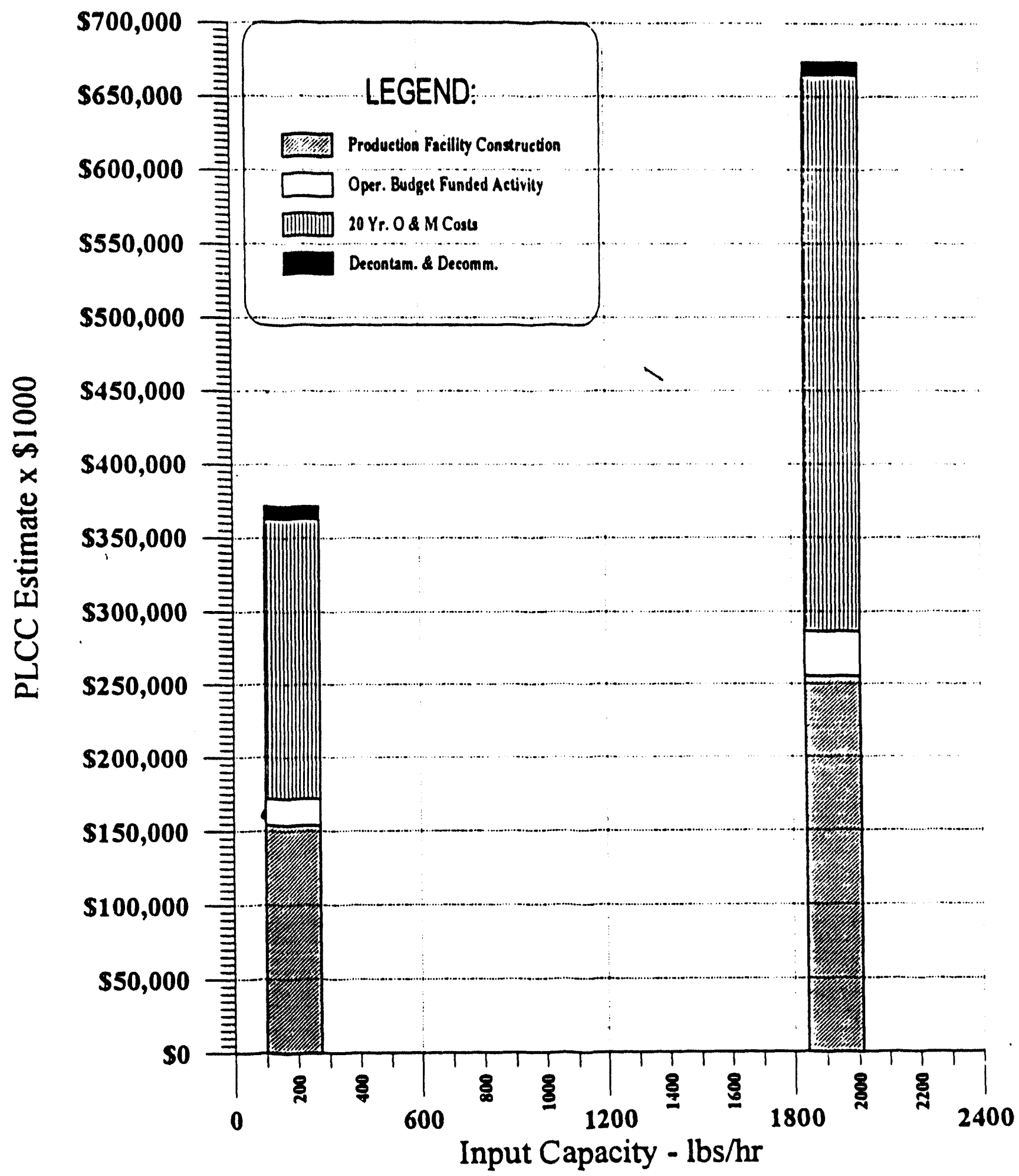

Flgure 3-4. Cost versus capacity histogram for GTCC LLW receiving, preparation, and shipping facility (cost module BB). 


\section{INCINERATION FACILITY (COST MODULE CC)}

\subsection{Basic Information}

The incineration facility, shown in Figure 4-1, must be either used in conjunction with the receiving, preparation, and shipping facility (see cost module BB) or constructed next to existing facilities where similar functions are already available. The incineration facility incorporates thirteen major unit operations that process and package GTCC-LLW. The facility incinerates waste and solidifies the resulting ash. Unit operations are shown in Figure 4-2.

The facility treats combustible solid waste such as compactible trash, cartridge filters, and ion exchange resins, and partially combustible solids such as solidified resins, and solidified organic liquids. Spent resins and other moisture bearing wastes are placed in combustible containers (such as plastic bags, drums, or cardboard boxes) and sent to the incinerator.

\subsection{Technical Basis and Assumptions}

\subsubsection{Functional and Operational Description}

The incoming waste is fed to the incinerator via an input preparation and feed unit, where the waste is crushed and shredded or otherwise prepared for incineration. All combustible materials are thermally destroyed while inert materials pass through with the ash. In the solidification feed and preparation unit operation, the ash discharged from the incineration unit is collected and cooled. Upon demand, the ash is transported to a solidification unit, where it is mixed with plant wastewater and a binder (such as Portland cement) at a predetermined ratio to produce a stabilized waste form. After the components are properly mixed, the mixture is poured into disposal containers. The filled containers are capped and sent through a wash unit operation, where the drums are sealed and then washed by a high-pressure water spray. A waste sampling unit is also provided at this station. The containerized waste is then sent back to the receiving, preparation, and shipping facility.

The incineration facility generates two secondary waste streams: liquid and offgas. The incinerator offgas unit operation consists of three treatment trains; dry offgas, wet offgas and HEPA filtration.' The dry offgas treatment is equipped with high temperature combustion and filtration equipment (such as ceramic filters). In this train any volatile organic matter or soot released from the incinerator chamber is burned. Furthermore, any floating ash and large particulate are filtered. Discharge from the dry offgas train is fed to the wet offgas train where the gas is first scrubbed to remove particulate, $\mathrm{SO}_{2}, \mathrm{HCl}$, and $\mathrm{NOx}$. The gas discharged from the scrubber is dried by passing it through demisters, condensers, and gas reheaters. The dried gas is fed to the HEPA filtration train to remove the remaining particulate, as stipulated in the facility offgas discharge criteria. Before release into the environment, the treated offgas is sampled and analyzed to ensure compliance with the discharge permit. A surge tank retains offgas for reprocessing in the event of a process upset.

Secondary liquid waste is processed through a treatment unit, where dissolved and suspended solids (organic and inorganic) are removed. Treated wastewater is recycled for reuse. Sludge and other wet solids are either fed into the incinerator or sent to the solidification unit for processing. 


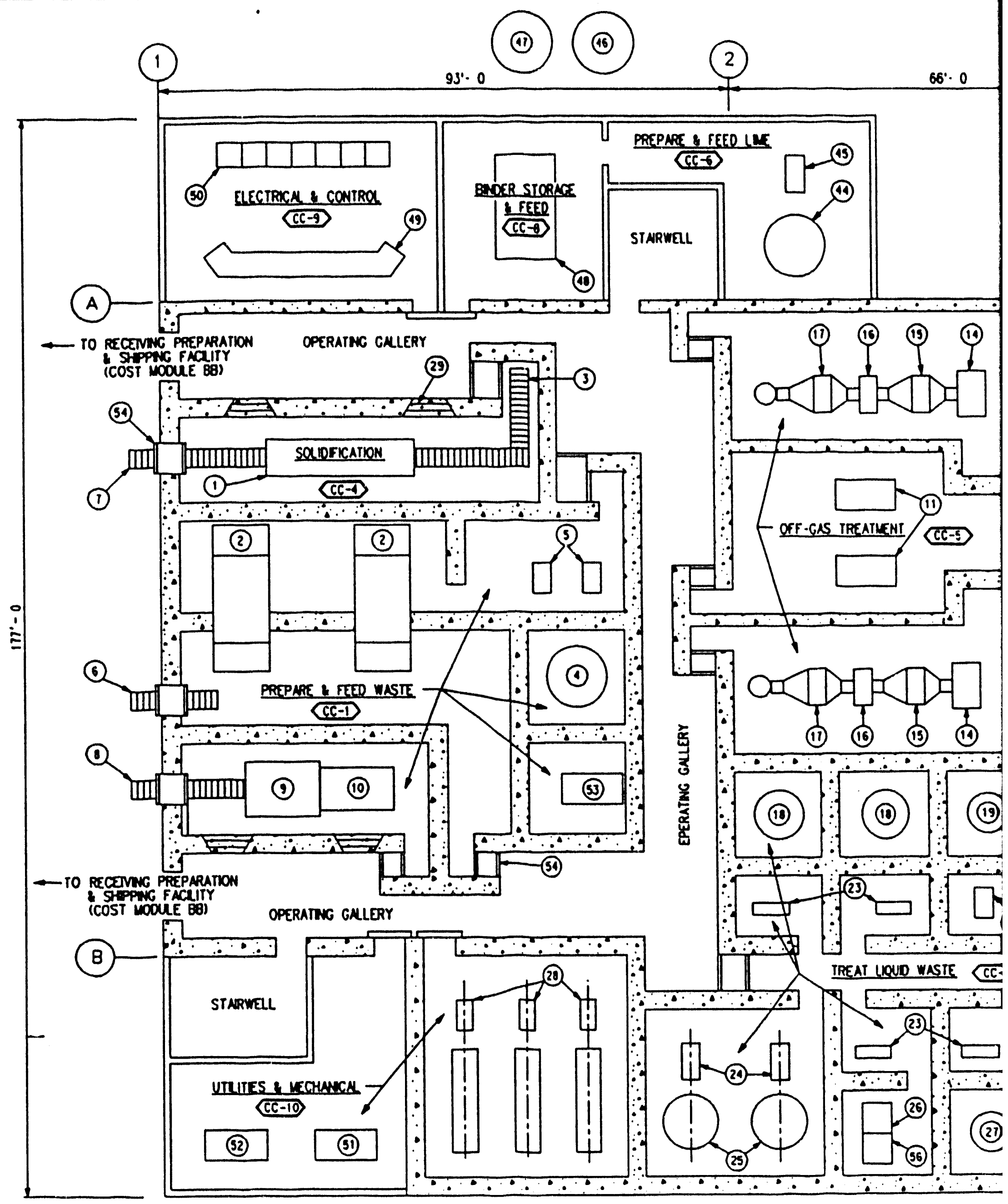

Figure 4-1. GTCC LLW incineration facility plan (cost module CC). 
$65^{\prime} \cdot 0$
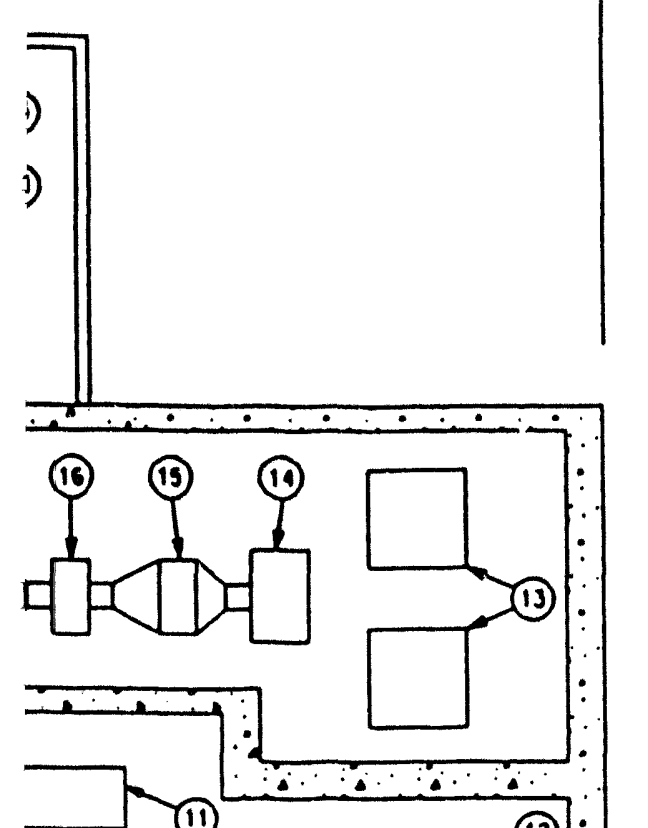

RE
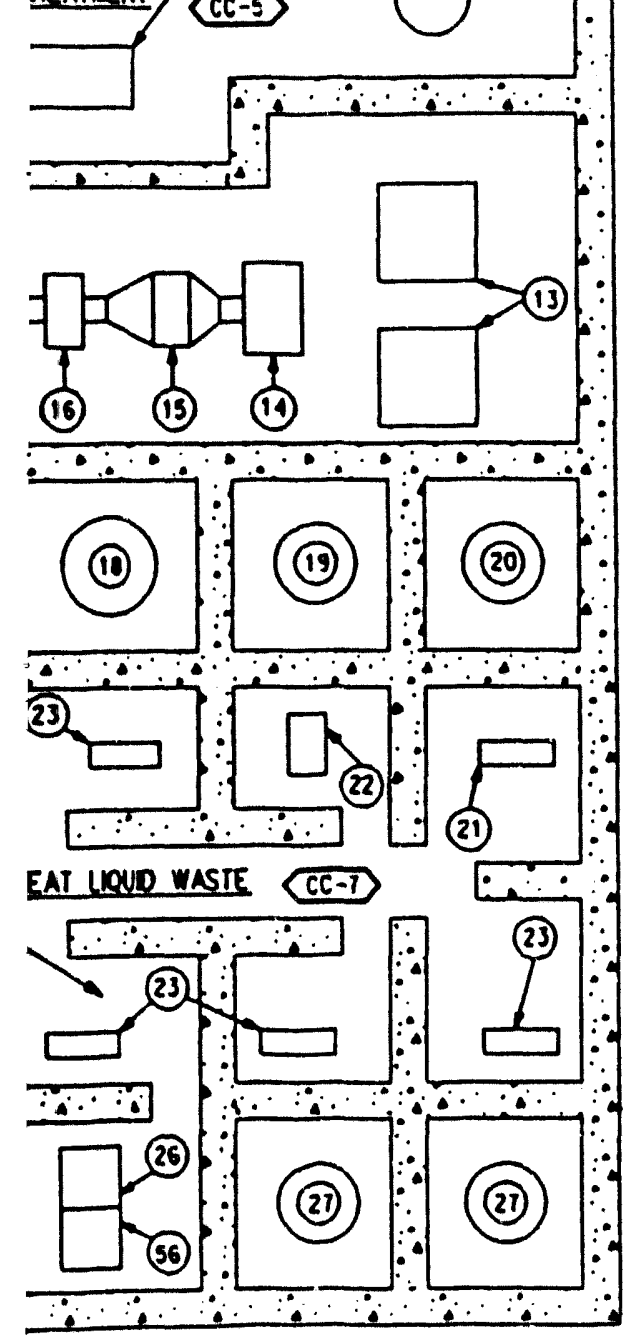

\section{MAJOR EOUIPMENT LIST}

(1) Saloif ICATION asserar

(2) IASTE LIFT HOIST

(3) ortu converor

(4) Resin oup hoppen

(5) resin transfer plap

(6) incominc uste comerop

(7) onew olscharce convetor

(C) incoume maste conveyor

(9) bux salos oup hopper

(10) Maste Baceing unit

(ii) auser

(12) stace

(11) HEPA FILTERS

(14) PEHEATER

(15) DE-HISTER Mo.2

(16) COMDENSER

(ii) DE-HISTER No.1

(10) Maste storuce inK

(19) EVAPORUTOR-YAPQR BOOY

(20) EVAPORUTOR-CONDEWSER

(21) Evaporutor-vaccur ples

(22) Evpooputor pus

(23) Pur

(24) Pus

(29) Treateo mater storuce the

(26) FILTRATION Umir

(217) ton-excunce ressets

(20) AIR FILTRATION LMIT

(29) SHIEloing rnoov (mp.)

(30) concentrate ina
(iII) concentaAte plap

(32) ASH STORACE hOPPER

(13) ASH TRUSFER STSTEM

(34) Er scrueser

(35) Scruber botrons tank

(16) SCRUBber PUAP

(ii) incierator vessel

(38) INCINERATOR FEED Shooter

(39) PRImRt CERMNIC FILTER

(40) SECONOAAY CERMUIC FILTER

(41) CERWMIC FIL TER MIN CRUE

(12) incinerator mintenunce crave

(13) vaste preparation cantry robot

(44) LILE oay tave

(15) LINE FEEDER

(46) LIK silo

(17) Binoer silo

(40) BINOER FILL UNIT

(49) mix contra puel

(50) wotor contra cemter

(31) copressed alr pacaAce

(32) InSTREMENT AIR PACXLCE

(3) SIIE ReDuction Unit

(34) AIR Locx (TrP.)

(35) 2 TON GeNTRY Cruve

(56) CARon FILTER

INCINERATOR (COST MOOULE CC)
LARGE FACILITY PLAN FIRST FLOOR

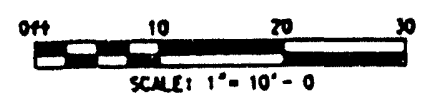




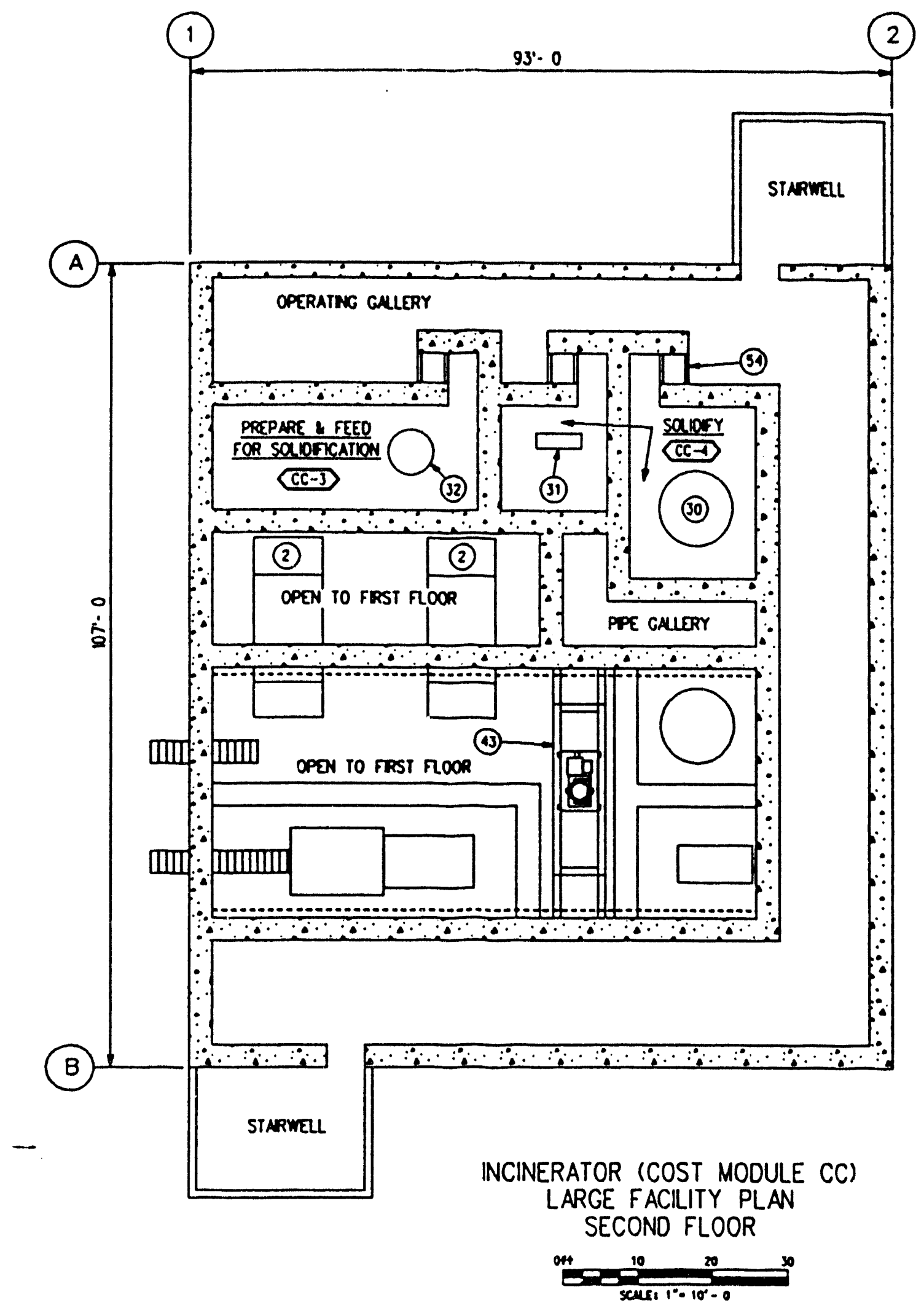

Figure 4-1. (continued). 


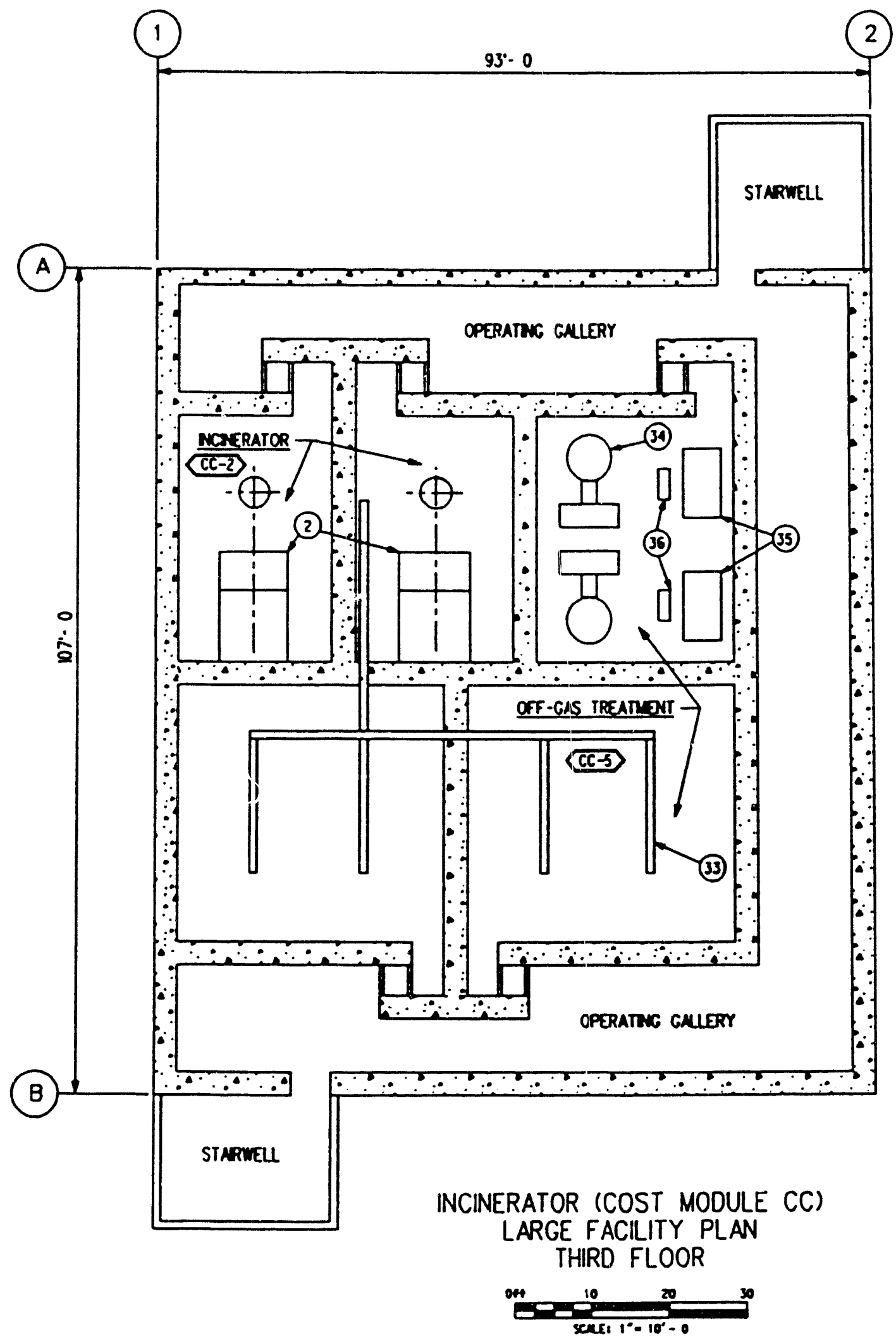




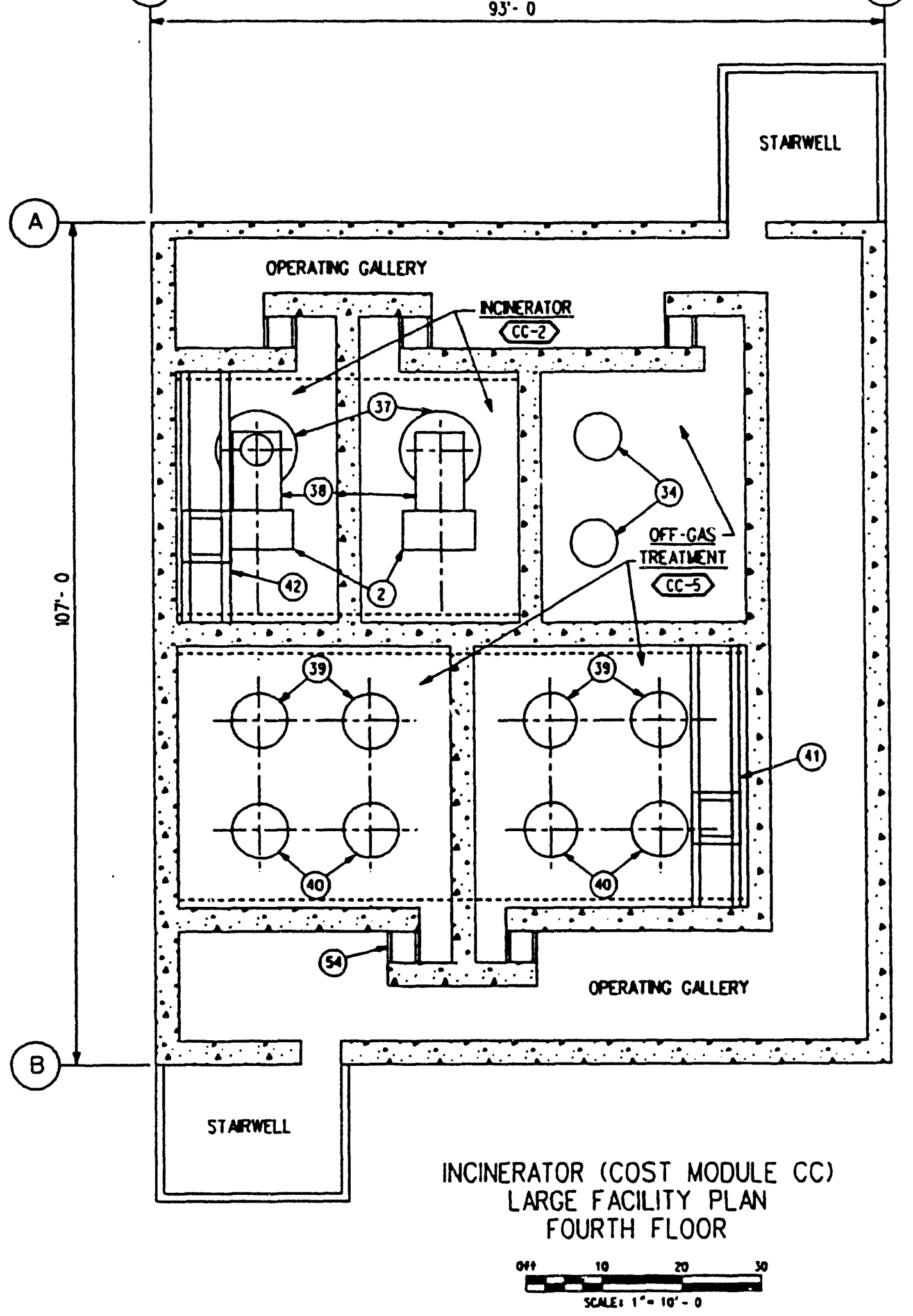

INCINERATOR (COST MODULE CC) ARGE FACILITY PLAN

Figure 4-1. (continued). 
(1) SOL 10IFICATION ASsELar

(II) COACENTRUTE PUP

(2) MASTE LIFT HOIST

(3) DRUM COMveron

(4) resin dus hopper

(32) ASH STORACE HOPPER

WELL

(5) besin transfer pusp

(6) incouncuc uaste comeror

(33) ASH TRUSSER SYSTEM

(7) orum olscharce comeyor

(i4) EI SCRubecR

(D) incountug maste comeror

(15) ScRubeer gotrons tave

(9) Bux sa los oup hopper

(36) SCRUBezR Pun

(10) maste baccinc unit

(i1) BLover

(12) stack

(13) HEPA FILTERS

(14) PE-HEATER

(15) $O E$ - MISTER MD.2

(16) conoenser

(17) DE-MISTER Mo.1

(3i) incinerutor vesseh.

(18) unste storace tanK

(19) EVAPORuICR-YAPQR BOOY

(30) IMCINERATOR FEED SHOOTER

(20) Evaporutor-candecser

(39) PRIMRP CERANIC FILTER

(21) Eveporutor-vacau plap

(40) SeconourY CERanic FIL TER

(41) cERQMIC FILTER MIN CRUTE

(12) imcinerator mintemunce cruse

(13) MASTE PREPARUIION CANTRY ROBOI

(44) LILE oAr TAN

(15) LIEE FEEDER

(16) LILE Silo

(17) BINOER SILO

(18) BINOER FILL UNIT

(49) min contra PANEL

(50) wotor contra cemter

(22) EVAPORUTOA+Plap

(23) pup

(24) Pur

(25) Treated mater stomace tak

(51) COPRESSED AIR PACXACE

(1)

(52) InStranent AlR PaCuace

(53) SIIE peDuction UNIT

(54) AIR LOCX (mP.)

(26) FILTRATION UNIT

(27) 10n-exanuce vessens

(23) AIR FILTRation LNIT

(29) SHIELDING VINOON (mP.)

(30) concentrate tha

(55) 2 TON Cantry CRave

(56) CAReOA FILTER 


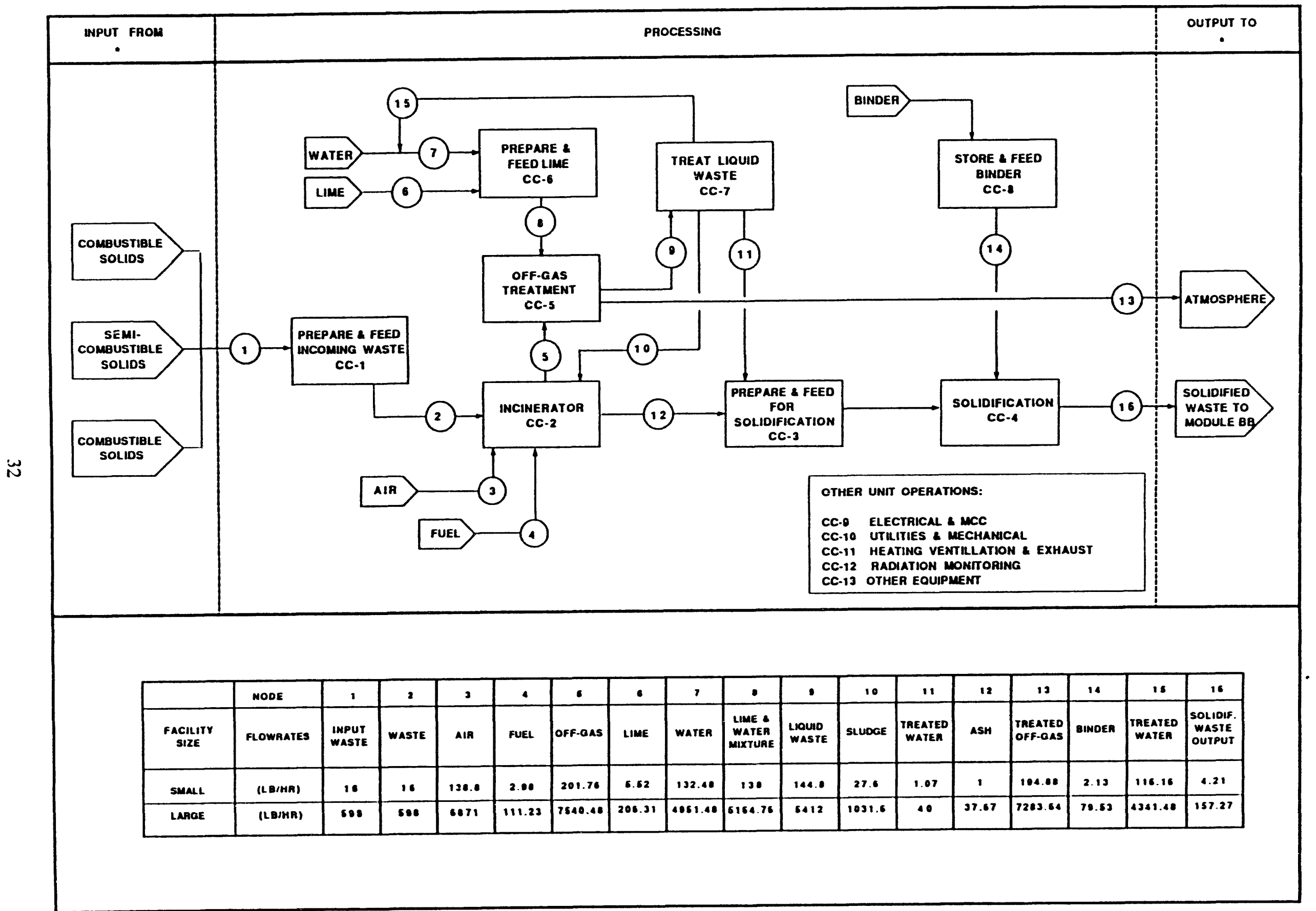

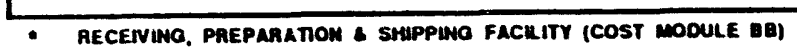

Figure 4-2. Process functional diagram for GTCC LLW incineration facility (cost module CC). 


\subsubsection{Facility Integration}

The incincration facility receives waste from the recciving, preparation, and shipping facility. Purchased materials include consumables such as personal protective equipment, laboratory material, solidification materials, packaging materials, and disposable and reusable shipping containers.

The output interface consists of packaged GTCC LLW drums transported to the receiving, preparation, and shipping facility. Treated exhaust gases are discharged to the atmosphere.

\subsection{Cost Bases, Assumptions, and Assessments}

General cost bases and assumptions are given in Appendix A. Facility-specific items are discussed below:

- The incinerator, offgas, and solidification units constitute the major equipment capital cost itcms. Incincrator prices are based on budgetary prices submitted by NGK-Locke, Inc., of Japan.

- Estimated operi.ting staff is shown in Table 4-1.

- Small and large facility capacities and unit costs are shown in Table 4-2.

\subsection{Cost Summaries}

Cost summaries for the GTCC-LLW incineration cost module is shown in Table 4-3. Histograms for cost versus capacity are given in Figure 4-3. 
Table 4-1. Estimated operating staff for GTCC LLW incineration facility (cost module CC).

\begin{tabular}{clcc}
$\begin{array}{c}\text { Unit } \\
\text { operation }\end{array}$ & \multicolumn{1}{c}{ Description } & $\begin{array}{c}\text { Small } \\
\text { (FTE) }\end{array}$ & $\begin{array}{c}\text { Large } \\
\text { (FTE) }\end{array}$ \\
\hline CC-1 & Prepare and feed incoming waste & 1 & 4 \\
CC-2 & Incinerator & 3 & 6 \\
CC-3 & Prepare and feed for solidification & 1 & 2 \\
CC-4 & Solidification & 1 & 2 \\
CC-5 & Offgas treatment & 1 & 6 \\
CC-6 & Prepare and feed lime & 1 & 3 \\
CC-7 & Treat liquid waste & 1 & 3 \\
CC-8 & Store and feed binder & 2 & 2 \\
CC-9 & Elec. distribution and motor & & 2 \\
& control center (MCC) & 1 & 3 \\
CC-10 & Utilities and Mechanical & 1 & 1 \\
CC-11 & Heating, ventilation, and exhaust & 0 & 1 \\
CC-12 & Radiation monitoring & 0 & 4 \\
CC-13 & Other equipment & $\underline{0}$ & 39 \\
& Total & 13 & 2 \\
\hline
\end{tabular}

Table 4-2. Capacities and unit costs for GTCC LLW incineration facility (cost module CC).

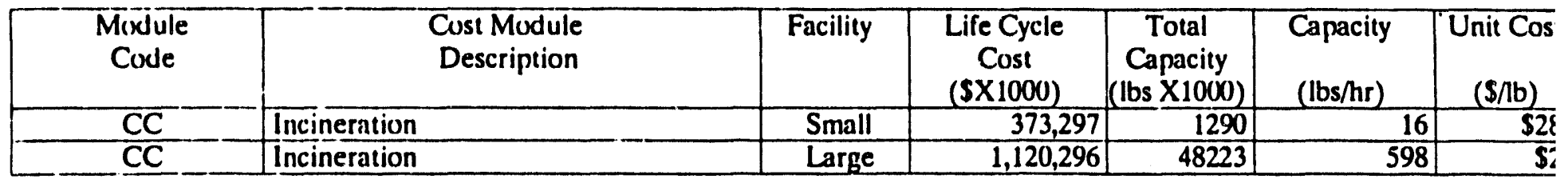


Table 4-3. PLCC estimate summary for GTCC LLW incineration facility (cost module CC).

\begin{tabular}{|c|c|c|}
\hline $\begin{array}{c}\text { Cost } \\
\text { composent }\end{array}$ & Coul Items & $\begin{array}{c}\text { Coat } \\
(S \times 1000) \\
\text { Small }\end{array}$ \\
\hline
\end{tabular}

1.3 Installation costs

1.4 Project managemeal before title I ( $10 \%$ of 1.1 througb 1.3)

is Contingency

( $25 \%$ of 1.1 tbrough 1.4 )

Subtotal 1.0

\begin{tabular}{|c|c|}
\hline $\begin{array}{r}\$ 1,650 \\
550 \\
5150 \\
5185 \\
\$ 509 \\
S 2.54\end{array}$ & $\begin{array}{r}\$ 1.650 \\
\$ 50 \\
\$ 150 \\
\$ 185 \\
5509 \\
\$ 2.544\end{array}$ \\
\hline $\begin{array}{r}\mathbf{2}, 400 \\
\mathbf{s 6 0} \\
\mathbf{s 4 4} \\
\mathbf{S 1 2 0}\end{array}$ & $\begin{array}{r}22,400 \\
\$ 360 \\
s 84 \\
\$ 120\end{array}$ \\
\hline $\begin{array}{r}\$ 180 \\
\$ 750 \\
\$ 270 \\
\$ 1200 \\
5205\end{array}$ & $\begin{array}{r}\mathbf{S 1 8 0} \\
\mathbf{5 7 5 0} \\
\mathbf{5 2 7 0} \\
\mathbf{S 1 2 0 0} \\
\mathbf{5 2 0 5}\end{array}$ \\
\hline $\begin{array}{r}\$ 120 \\
\$ 1,122 \\
S 5,611\end{array}$ & $\begin{array}{r}\$ 120 \\
\$ 1,122 \\
\$ 5,611\end{array}$ \\
\hline
\end{tabular}

Demonstration couls

2.1 Mappower costs duriog demoastration

$\begin{array}{ll}2.2 \text { Desiga coul } & (30 \% \text { ol } 2.5) \\ 2.3 \text { Inspection cout } & (7 \% \text { or } 2.5) \\ 2.4 \text { Project managemeat } & (10 \% \text { of } 2.5)\end{array}$

2.4 Projeci managemed

( $10 \%$ of 2.5 )

25 Construction cost

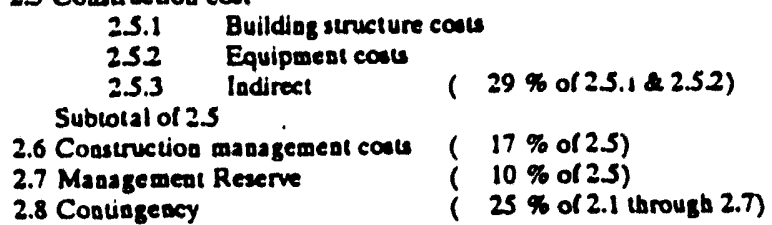

( $29 \%$ of $25.1 \% 2.52)$

2.6 Construction managemeal cols

( $17 \%$ or 25 )

( $10 \%$ or 2.5 )

( $25 \%$ or 2.1 through 2.7 )

Subcolal of 2.5

2.7 Managemeat Reserve

2.8 Contingency

Sublotal 2.0

S5,611

Production facility construction costs

3.1 Desiga coul

32 laspection cont

( $18 \%$ of 3.4 )

3.3 Project management

( $7 \%$ o(3.4)

( $10 \%$ of 3.4)

$\$ 14,560$

$\$ 5,662$

$\$ 8,089$

$\mathbf{5 3 8 , 8 6 8}$

3.4 Cosastruction cost

$$
\begin{array}{ll}
3.4 .1 & \text { Buildiag structure conts } \\
3.42 & \text { Equipmeat costs } \\
3.4 .3 & \text { Indireet }(29 \% \text { or } 3.4 .1 \% 3.42)
\end{array}
$$

Subtoral ol 3.4

3.5 Consuruction managemeat

3.6 Masagemeat Reserve

( $17 \%$ of 3.4 )

( $10 \%$ of 3.4)

3.7 Contiageacy

( $25 \%$ or 3.1 through 3.5 )

Sublotal 3.0

Operations Budget Funded Activitien (See Sect. 7 )

4.1 Conceptual deaiga

( $15 \%$ of 3.0$)$

42 Salety asuurace

( $1 \%$ of 3.0$)$

4.3 NEPA permittiog (\$ 6 Mill for ElS, S1 Mill for EA)

4.4 Preparation for operations

( $100 \%$ of 5.0$)$

4.5 Project Managemeat

( $10 \%$ ol 4.1 through 4.4)

Sublotal 4.0

Total laitial Coal $(1.02 .0 .3 .0 \times 4.0)$

$\$ 33.318$

829,386

518.184

$\$ 80,888$

$\$ 13,832$

$\$ 8.089$

\$30,750

$\$ 161,878$

S15.115

521.593

$\$ 52.287$

$\$ 115,102$

S48,543

$\$ 215.932$

$\$ 36,924$

$\$ 21.593$

582.108

$\$ 432,133$

51.619

56,000

$\$ 8,499$

$\$ 1,855$

520.401

56,482

54,321

$\$ 6.000$

$\mathbf{5 3 0 , 3 9 9}$

9190,434

54,720

$\$ 190,434$

$\$ 49210$

Operating and maintainence costs (Loadiag / Ualoading Period)

S.1 Anaual opentiag conte

52 Anaual utility couts

5.3 Anoual material coots

S.4 Aouual maiotainence couts

5.5 Coatingency

( $25 \%$ of 5.1 through 5.4 )

5.6 Subtotal 5.0

Sublotal 5.0)

$\$ 1,820$

546

S410

54,523

$\$ 1,700$

$\$ 8,499$

$\$ 169,980$

55,460
$\$ 141$
5785
517,933
56,080
530,399
5607,980
520,106

7.0

Decontamination \& Decommisaioning

$\$ 12,883$

$\$ 1,120,296$

8.0 ROM Life cycle conts (20 years operation)

$\$ 373.297$ 


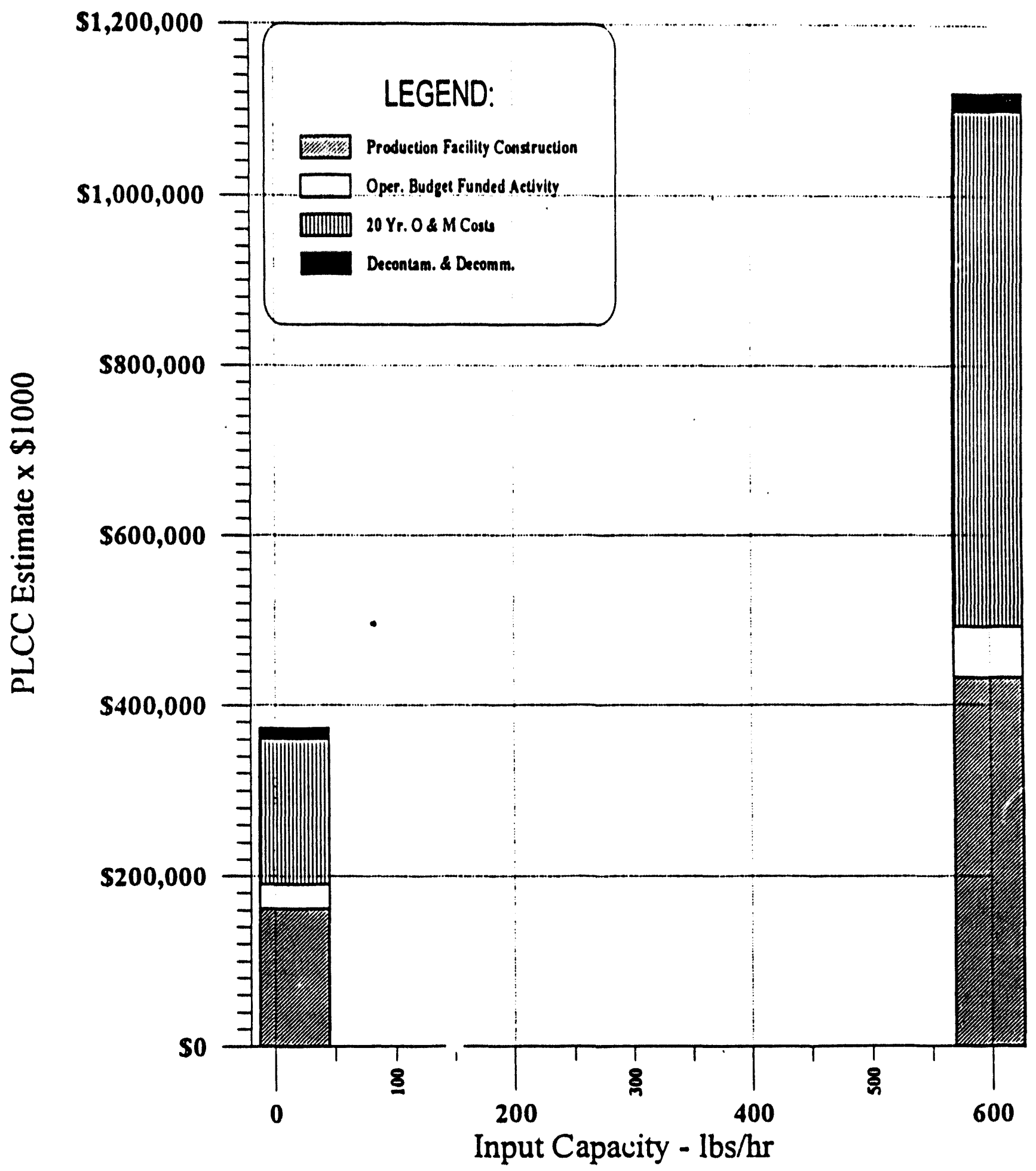

Figure 4-3. Cost versus capacity histogram for GTCC LLW incineration facility (cost module CC). 


\section{METAL MELTING FACILITY (COST MODULE DD)}

\subsection{Basic Information}

The metal melting facility, shown in Figure 5-1, is used either as an addition to the existing facility where similar functions are already available, or in conjunction with the receiving, preparation, and shipping facility (cost modulc BB). Unit operations are given in Figure 5-2.

The facility involves ten process unit operations that convert incoming contaminated metals into cast ingots and cast slag and treat secondary liquid and gaseous wastes. Sccondary waste treatment by-products, such as offgas scrubber sludge are solidified and placed in drums.

The facility can process ferrous and nonferrous bulk metals of various shapes and forms such as $w$ astc containers, failed cquipment, and contaminated scrap structural stcel. The cost module is designed to handle incoming waste containing up to $10 \%$ combustibles. However, this facility cannot sort different metal types nor is it equipped to dismantle large equipments or reduce the size of large components. Therefore, the metals must arrive at the facility in drums and presorted.

\subsection{Technical Bases and Assumptions}

\subsubsection{Functional and Operational Description}

Drums or transport bins containing contaminated metals are delivered to the feed preparation unit operation where they are staged and size reduced, if needed, in preparation for melting. Drums or transport bins containing waste that needs size reduction. are dumped on a size reduction device where metals are cut using remote torches or a shredder. The shredded and size-reduced metals are placed back on transport bins and sent to the melter unit operation.

The melter unit operation is equipped with a bulk material feed system and a drum feed system. Contents of the drums and bins are fed to the melter through a bulk fecd system. Alternatively, drums may be fed intact through the melter drum feeder.

In the melter, the metals are melted and accompanying combustible materials are thermally destroyed. During the melting process, molten slag containing impurities and most of the radionuclide contamination is separated from the molten metal. Stream containing molten metals is sent to the metal casting and cooling unit operation, and the slag stream is directed to the slag casting and cooling unit operation.

In both casting operations molten materials are poured into water-cooled canisters. Following the coul down operation. the canisters are sealed and sent to container washing and inspection unit operation. Grouting agent is added to the slag canister before it is sealed. Sealed containers are then staged for disposal.

The melting process is designed to precipitate the radioactivity in the slag stream so that a large portion of the casted metals can be sent to shallow land disposal sites as LLW. However, the casted slag will be highly radioactive and must be disposed of as GTCC LLW.

The unit operations produce two secondary waste streams: liquid and offgas. Secondary liquid waste is processed in the liquid waste treatment unit that removes dissolved and suspended solids 


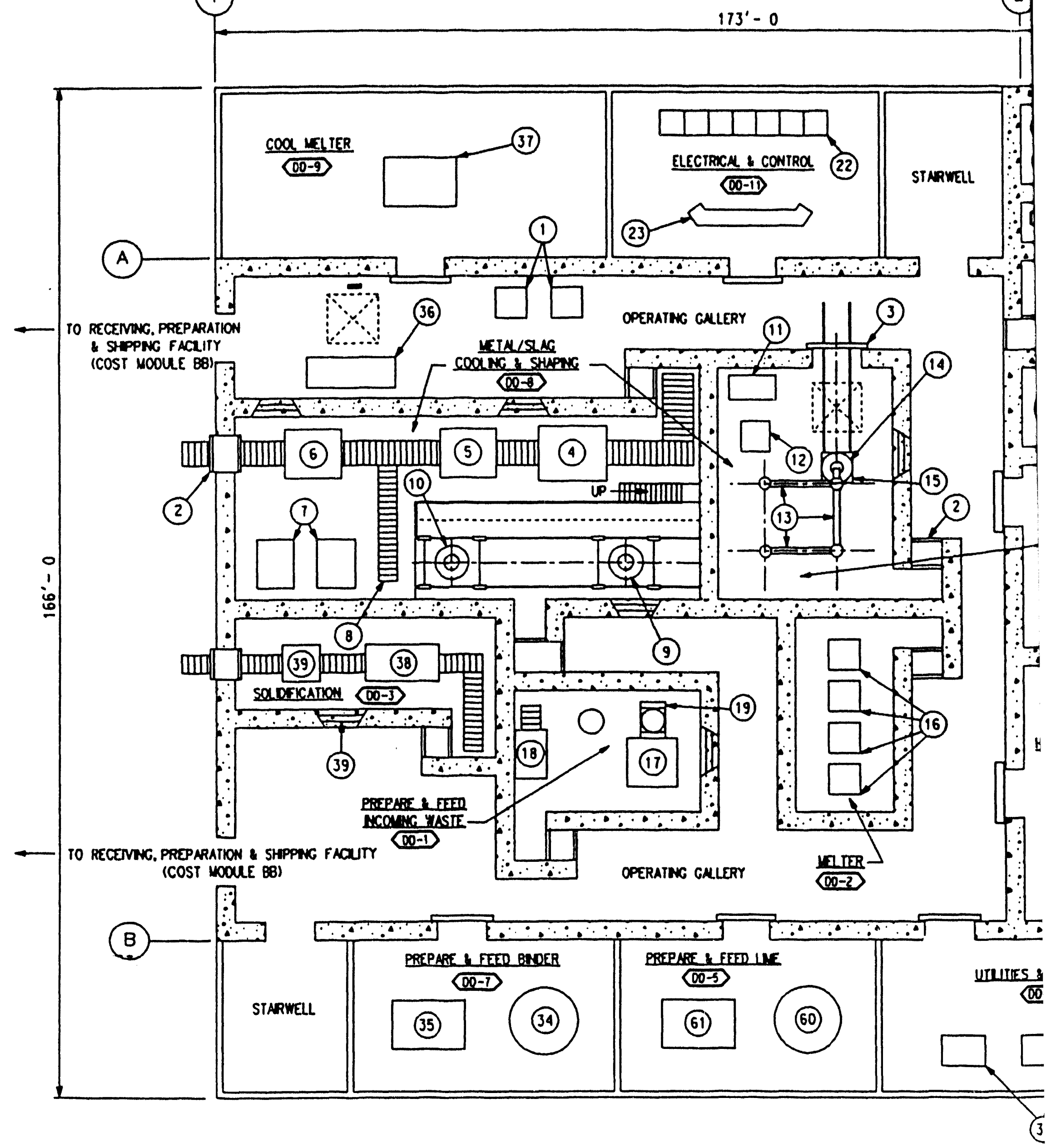

Figure 5-1. GTCC LLW metal melting facility plan (cost module DD). 
(2)

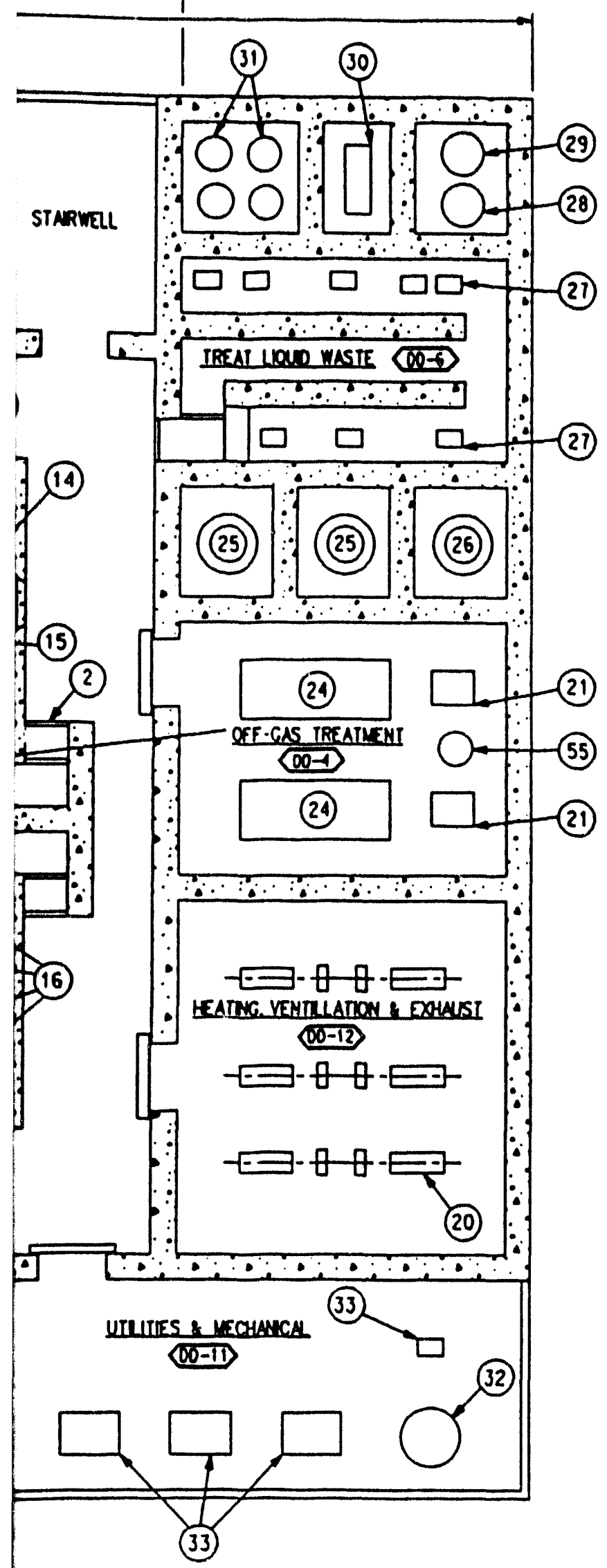

\section{MAJOR EQUIPMENT LIST}

(1) SLAC COO ING BLOEER

(2) $A$ IA lock i imp.)

(3) SHIELL DOOA

(4) SLac crouting Unit

(5) SLACNETIN CANISTER CAPPER

(6) CANISTER OECON UNIT

(1) canister con inc chnaer

(1) canister coneron

(9) vetul incot vacuin chavera

(10) SLac imcor vacum chuneer

(11) KEL TER OXYGen feEo CONTRQLLR

(12) vel ter IMet alR gloter

(13) FIL TER ASH CONVEYOR

(14) ASH ORLW SHIELO CASK

(15) SHIELO CASX CART

(16) vacuen purp

(11) SHFeocer

(18) OUST Calection UNIT

(19) SHREDOER CONEYOR

(20) AIR HANO IMGMEPA FIL TER UMIT

(21) Buter

(22) WTos contra center

(23) Min contra pMat

(24) ELLTER OFF-GAS MEPA FILTER

(25) TrEateo vaste inK

(26) Incoulno LIOWIO VASTE INK

(27) PUP

(20) SPENT RESIN TNK

(29) sluoce tNK

(30) Fil tration unit

(3i) ION EXCHNate UNIT

(32) SERVICE VATER STORACE taA

(33) AlR COPRESSORS
(34) SO IOIFICATION ACEMT STORACE SILO

(33) orven rill Unit

(36) CROUI MIXER/PUP

(3i) velter coo ine maten unit

(30) Sa iolf ication assevar

(39) Shieloinc winoon ( $\mathrm{mP}$. )

(40) ontu converon

(41) onuwain converor

(12) SIZE ReOucrion rhale \& roas

(13) mster slave muipuator

(44) 2 TON Gamiar crue

(15) LEL TER ORUN fEeOER

(46) IEL TER BUX FEEDEP.

(47) bux maste hopper

(10) Ieliea vacuin chanecr

(19) miliemance crase

(50) monarall/holst

(51) CERAMIC PRIMARY FILTERS

(32) CERUMIC SECONOAAT FILTERS

(53) mintenAnCE cRne

(54) FILTER ELEKEMT CRUSHER

(35) stack

(56) pe hEATER

(57) $x \in$ MISTER $A$

(30) condenser

(59) $D E$ - HISTER $R$

(6) LIVE Storace thx

(6) LINE paEparation SYSTEM

METAL MELTING (COST MODULE DO) LARGE FACILITY PLAN
FIRST FLOOR

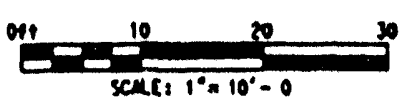




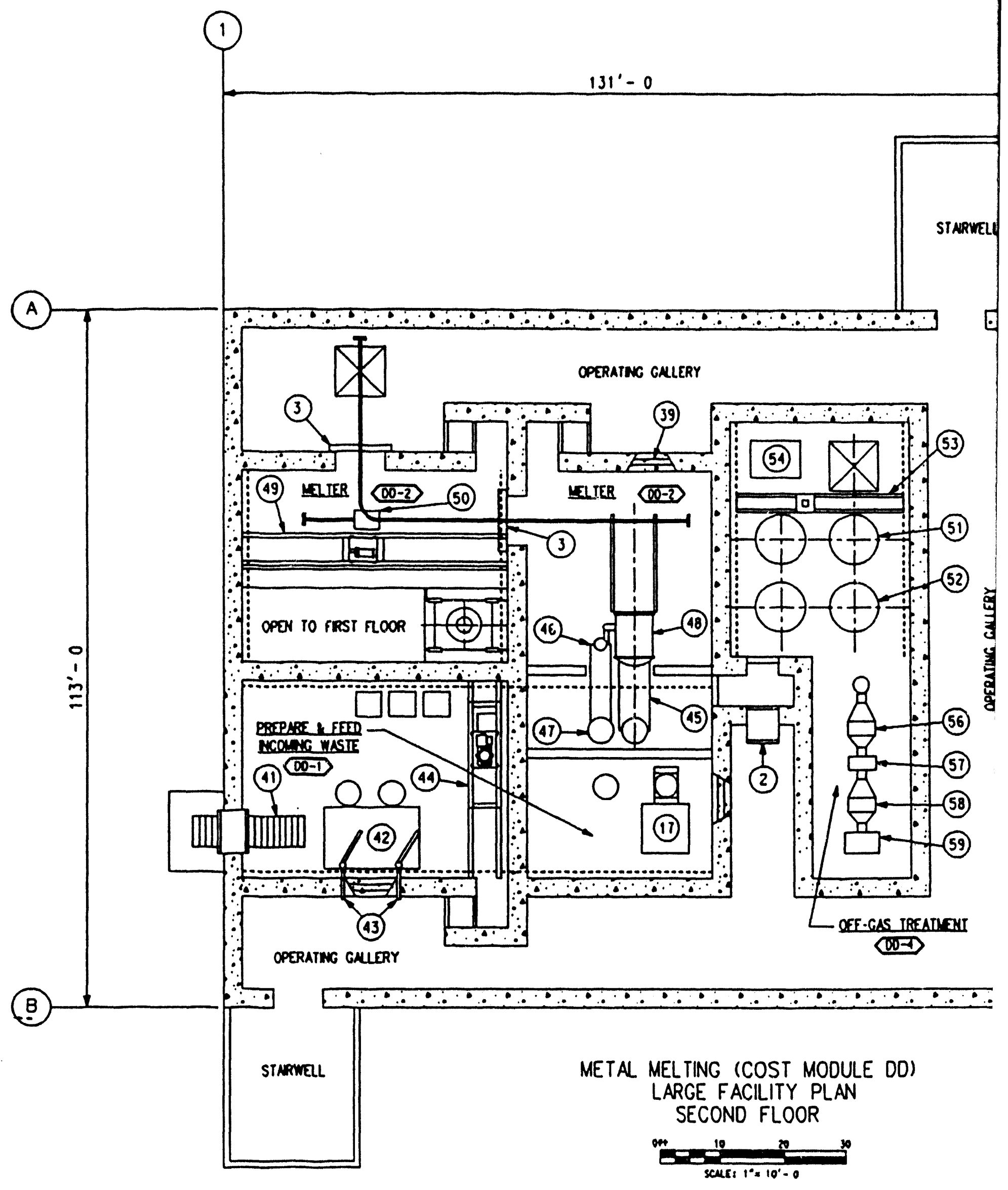

Figure 5-1. (continued). 


\section{MAJOR EQUIPMENT LIST}
(1) SLAC COOANG BCOTER
(34) SQ IOIF ICATION ACEMT STORAGE SILO
(2) AIR LOCX ITYP.)
(35) ORUM FILL UNIT
(3) SHIELL DOOR
(4) SLAC CROUTING UNIT
(36) GROUT MIXERPPUP
(5) SLACNETN CANISTER CAPPER
(37) GeL TER COOA INO MATER UNIT
(6) CANISTER DECON UNIT
(30) Sa loIf ICATION ASSELOCY
(7) canister coou inc chnaer
(39) SHIEloInC vinoor (TTP.)
(D) canister converor
(10) oruy converos
(9) Letal incot vacuin chamber
(41) orunusin converor
(10) Staig incot vacun chanoer
(12) SIZE REOUCTION TABLE \& TOOS
(11) EeL ter oxyeen feEo controler
(43) mster slave mavipuator
(12) velter imet alR gloter
(44) 2 TON Gantri cruse
(13) FILTER ASH CONEYOR
(14) ASH DRUM SHIELL CASK
(45) IEL TER ORLM FEEDER
(15) SHIELD CASX CART
(16) vacuem PUP
(11) SHREDOER
(10) OUST Calection UNIT
(19) SHREDOER CONVEYor
(20) AIR HANO INGMEPA FIL TER UNIT
(16) WEL TER BUK FEEDER
(47) BuRK MASTE hOPPER
(10) vel ter vacum chnaer
(21) Borer
(22) MTOR CONTRa CEMTER
(23) MIN contra PMEL
(24) KEL TER OFF-GAS HEPA FILTER
(19) mI TERANCE CRAE
(50) Momorall MOIST
(51) CERNMIC PRILUAY FILTERS
52. CERMNIC SECCAOARY FIL TERS
(25) TREATED MSTE TAM
(26) Incoutho Llowio vaste tak
(21) PUP
(20) SPENT RESIM TNK
(29) Sluoce tak
(30) FILTRation unit
(ji) ION Exchunce unit
(53) mintemance cruve
54 FILTER ELELENT CRUSHER
(55) srica
(56) DE MISTER at
(51) candenser
(58) DE-MISTER R
(59) RE HEATER
60) LILE STOPuce tha
(32) SERvice vater storace tNa
(33) Air compressoas
(61) LILE PREPARUTION SYSTEM
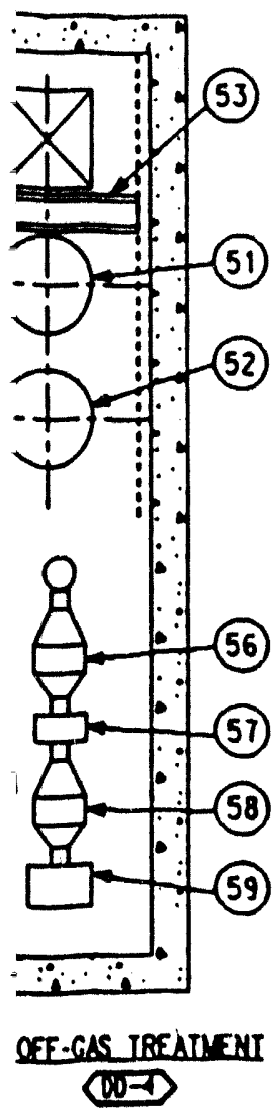

ULE DO)

$W$ 


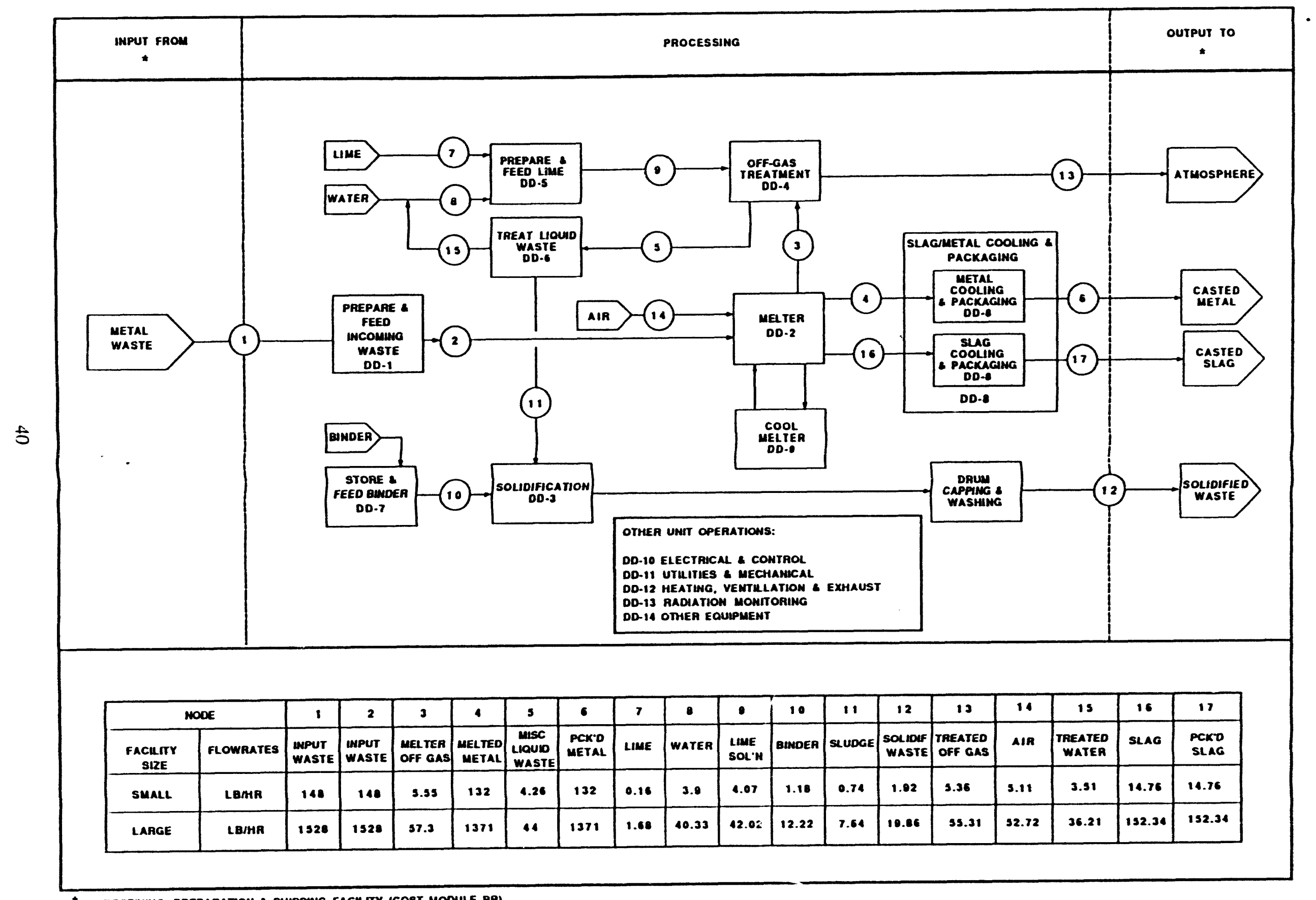

\footnotetext{
- MECENHG, PREPARATIOH \& SHIPPANO FACHTY (COST MODULE BQ)
}

Figure 5-2. Process functional diagram for GTCC LLW metal melting facility (cost module DD). 
(organic and inorganic) from the liquid waste. The facility recycles and reuses the treated wastewater so that there is zero discharge to the environment.

The melter offgas system is equipped with a dry treatment train, and a wet treatment train. Dry treatment train consists of high temperature HEPA filtration units with secondary combustion zapabilities (such as ceramic filters). In this train any combustible constituents are thermally destroyed, and particulate are removed from the off-gas stream. An induced air blower moves the conditioned effluent through the wet treatment train that is designed to remove $\mathrm{SO}_{2}, \mathrm{HCl}$, and $\mathrm{NOx}$. A surge tank will retain offgas for reprocessing melter exhaust in the event of a process upset.

In the solidification unit operation, liquid waste treatment sludge is mixed with a binder (such as Portland cement) in a drum. A predetermined mixing ratio is used to produce a stabilized waste form. The filled drums are washed with high-pressure water spray jets at the drum capping and washing unit operation.

Drums containing solidified waste, slag containers, and cast metal ingots are the main output from this facility. This output is ready for examinations by radioassay and final certification included in the receiving, preparation, and shipping facility.

It is assumed that a major portion of the metal ingots have a limited potential for reuse or may be disposed of safely in shallow land disposal units. The anticipated density of the solidified waste is $112 \mathrm{lb} / \mathrm{ft}^{3}$, and the densities for cast metal are the same as their absolute densities. The anticipated density of slag is $172 \mathrm{lb} / \mathrm{ft}^{3}$.

\subsubsection{Facility Integration}

Major input is contaminated scrap metal in drums or bins from the receiving, preparation, and shipping (cost module BB). Major O\&M purchased materials such as personal protective equipment, laboratory material, binder, and disposable containers are assumed to be consumable supplies, and their respective costs are estimated accordingly.

Major discharges from the system are metal ingots canisters, slag canisters, and drums of solidified LLW/MLLW and GTÇC-LLW waste that are transported to a receiving, preparation, and shipping facility. Treated offgas is discharged into the atmosphere.

\subsection{Cost Bases, Assumptions, and Assessments}

General cost bases and assumptions are given in Appendix A. Facility-specific items are discussed below:

- Major equipment capital cost items include the melter, casting, and cooling equipment; offgas treatment and its supporting equipments; and solidification units.

- Estimated operating staff is shown in Table 5-1.

- Budgetary cost for the preparation and feed unit is based on vendor quotes.

- Melter prices are based on budgetary quotes from Ajax Corporation and Retec Corporation. 
Table 5-1. Estimated operating staff for GTCC LLW metal melting facility (cost module DD).

\begin{tabular}{llcc}
\hline $\begin{array}{l}\text { Unit } \\
\text { operation }\end{array}$ & \multicolumn{1}{c}{ Description } & $\begin{array}{c}\text { Small } \\
\text { (FTE) }\end{array}$ & $\begin{array}{c}\text { Large } \\
\text { (FTE) }\end{array}$ \\
\hline DD-1 & Prepare and feed incoming waste & 1 & 9 \\
DD-2 & Melter & 3 & 12 \\
DD-3 & Solidification & 1 & 3 \\
DD-4 & Offgas treatment & 1 & 3 \\
DD-5 & Prepare and fecd lime & 1 & 3 \\
DD-6 & Treat liquid waste & 0.5 & 2 \\
DD-7 & Store and feed binder & 0.5 & 2 \\
DD-8 & Slag cooling, shaping, and packaging & 0.5 & 2 \\
DD-9 & Cool melter & 0 & 0 \\
DD-10 & Electrical and control & 0 & 1 \\
DD-11 & Utilities and mechanical & 1 & 1 \\
DD-12 & Heating, Ventilation, and Air Conditioning & 1 & 1 \\
DD-13 & Radiation monitoring & 1 & 1 \\
DD-14 & Other equipment & 1 & 4 \\
& Total & 12 & 43 \\
\hline
\end{tabular}

- NGK-Locke, Inc., and Callidus Technologies budgetary prices were used for the dry and wet offgas treatment trains.

- The selected solidification unit is manufactured by Stock Equipment Company of Chagrin Falls, Ohio. This supplier provided a quote for a unit similar to one sold to DOE for a facility at the Savannah River Site.

- Small, and large facility capacities and unit costs are shown in Table 5-2.

\subsection{Cost Summaries}

Cost summaries for the GTCC-LLW metal melting cost modules are shown in Table 5-3. A histogram for cost versus capacity is given in Figure 5-3. 
Table 5-2. Capacities and unit costs for GTCC LLW metal melting facility (cost module DD).

$\begin{array}{lll}\text { Facility } & \text { Capacity (lb/hour) Unit Cost (\$/b) }\end{array}$

\begin{tabular}{|c|c|c|c|c|c|c|}
\hline $\begin{array}{l}\text { Module } \\
\text { Code }\end{array}$ & $\begin{array}{l}\text { Cost Module } \\
\text { Description }\end{array}$ & Facility & $\begin{array}{l}\text { Life Cycle } \\
\text { Cost } \\
(\$ \times 1(0)(0)\end{array}$ & $\begin{array}{c}\text { Total } \\
\text { Capacity } \\
\text { (Ibs X10(0) }\end{array}$ & $\begin{array}{l}\text { Capacity } \\
\text { (lbs//ır) }\end{array}$ & $\begin{array}{c}\text { Unit Cost } \\
(\$ \cap b)\end{array}$ \\
\hline$\overline{D D}$ & Metal Melting & Smaili & 300,671 & $11 \overline{935}$ & 148 & $\$ 25$ \\
\hline$\overline{\mathrm{DD}}$ & Metal Melting & Large & 643,824 & 123218 & 1,528 & $\$ 5$ \\
\hline
\end{tabular}


Table 5-3. PLCC estimate summry for GTCC LLW metal melting facility (cost module DD).

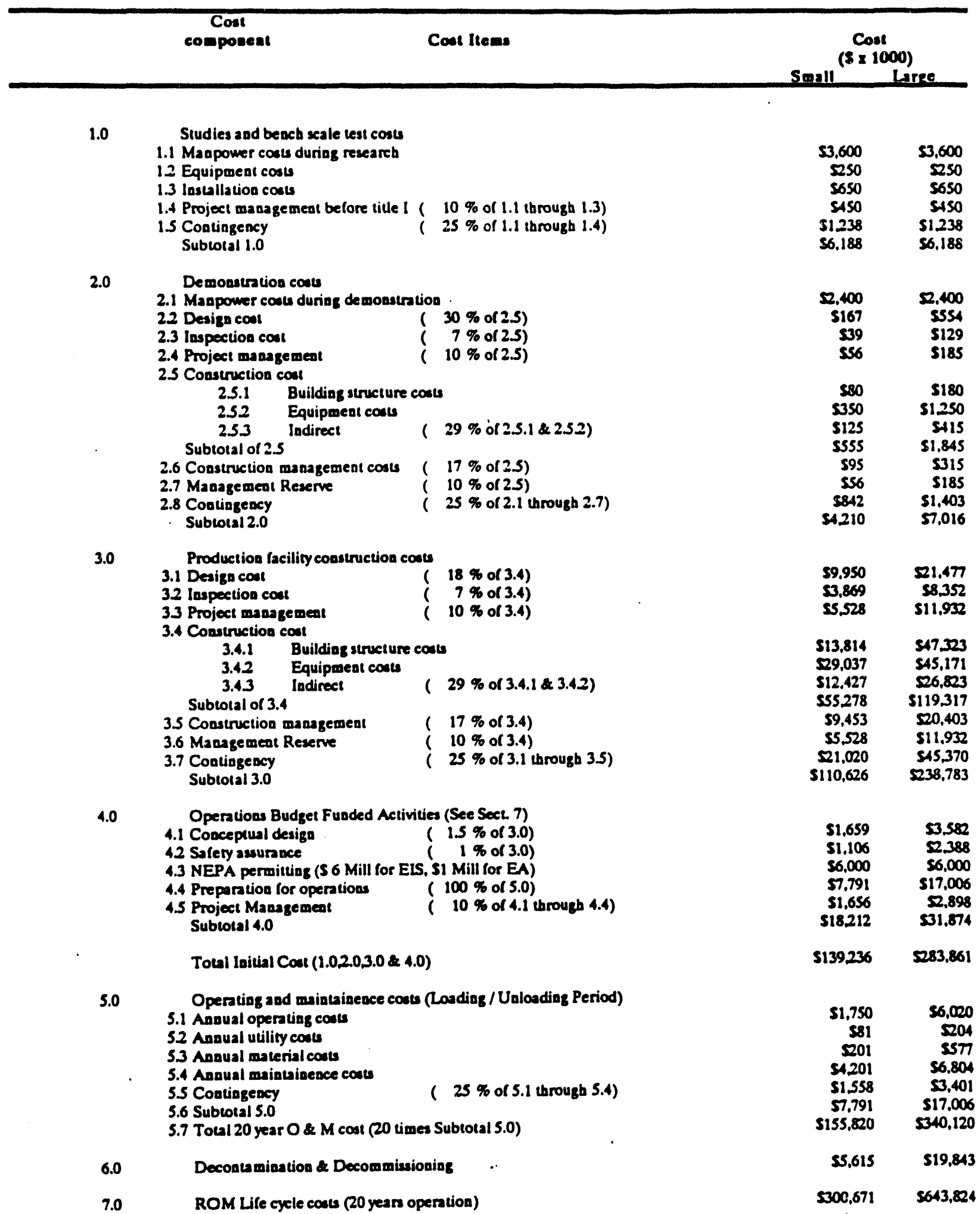




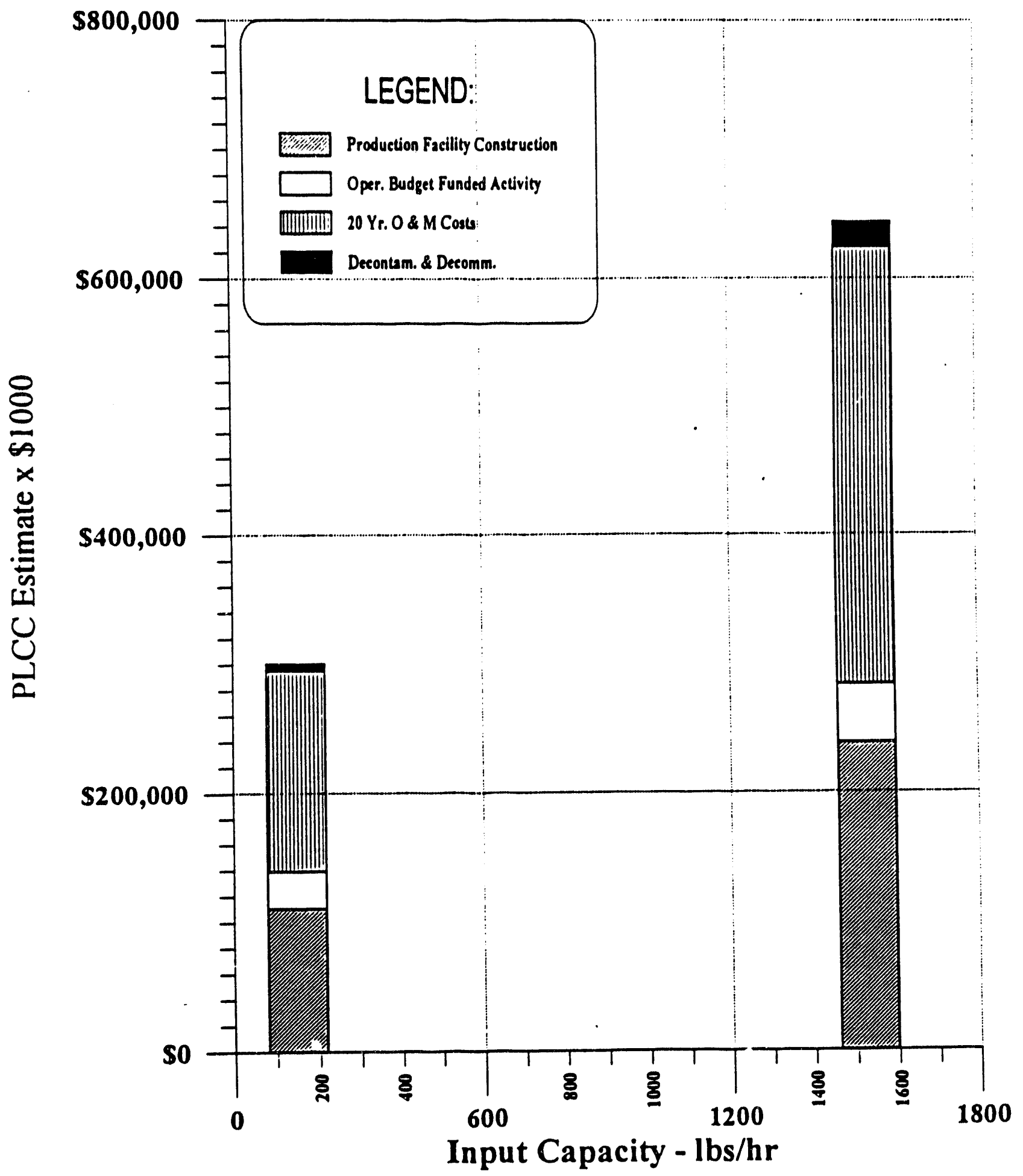

Figure 5-3. Cost versus capacity histogram for GTCC LLW metal melting facility (cost module DD). 


\section{SHREDDING/COMPACTION FACILITY (COST MODULE EE)}

\subsection{Basic Information}

The GTCC LLW shredding/compaction facility shown in Figure 6-1 comprises 16 main operating units that incorporate all buildings, systems, processes, equipment devices, controls and accessories required to solidify and compact the incoming solid waste. The facility can process combustible, partially combustible, and noncombustible solid waste and metal waste of various shapes and forms. The supercompaction equipment uses high compaction forces between 1,500 and 2,000 metric tons. Unit operations that accomplish these general functions are shown in Figure 6-2.

The facility is used in conjunction with the receiving, preparation, and shipping facility (cost module BB), or constructed next to an existing facility where existing functions are already available.

\subsection{Technical Basis and Assumptions}

\subsubsection{Functional and Operational Description}

The facility is designed to shred the incoming waste and package it in 85-gal drums. A dust collection/filtration unit treats air containing fugitive dust from the shredding operation. For the small and large facility the waste must be placed into drums and sent to a low-pressure compactor to maximize the waste volume reduction efficiency. After low-pressure compaction, the drum is remotely capped and a transfer device moves the capped drum to the supercompaction station where a lift device places the filled drums onto press conveyors. An operator selects a drum from one of the conveyors and feeds it to the press through an airlock located in the press negative pressure environmental chamber. A device pierces the drum to release any potentially trapped gases in the drum into the confined chamber. A high-pressure compactor (supercompactor) compresses the drum and transfers it from the press to a staging conveyor (or turntable). A lift device picks up the compressed drum and places it into one of several overpacks located on an adjacent conveyor. After each overpack is filled, the operator feeds it to a grouting station where grout is poured to fill the void. The grouted drum is moved to a seaming machine where a cap is placed on the overpack, seamed, and inspected. The operator moves the sealed overpack to a drum washing unit where highpressure water spray jets remove any loose contamination on the outside surface. The small facility has such low capacities that the expense of staging conveyor/turntable is not justified and, thus, not included. Any liquid discharged during press operation is directed to a sump. A liquid waste treatment and a solidification unit operation is provided to treat and solidify any liquid effluent or other potentially radioactive waste generated at the facility.

The compacted waste is ready for processing through a radio assay and final certification, which are included in the receiving, preparation, and shipping facility (cost module BB).

The anticipated density of the compacted waste is $65 \mathrm{lb} / \mathrm{ft}^{3}$. The solidified waste density is $112 \mathrm{lb} / \mathrm{ft}^{3}$.

\subsubsection{Facility Integration}

Primary facility input is waste in drums or transport bins from the receiving, preparation, and shipping facility (cost module BB). Major O\&M purchased materials such as personal protective equipment, laboratory material, binders, and overpacks are assumed to be consumable supplies and their costs are estimated accordingly. 


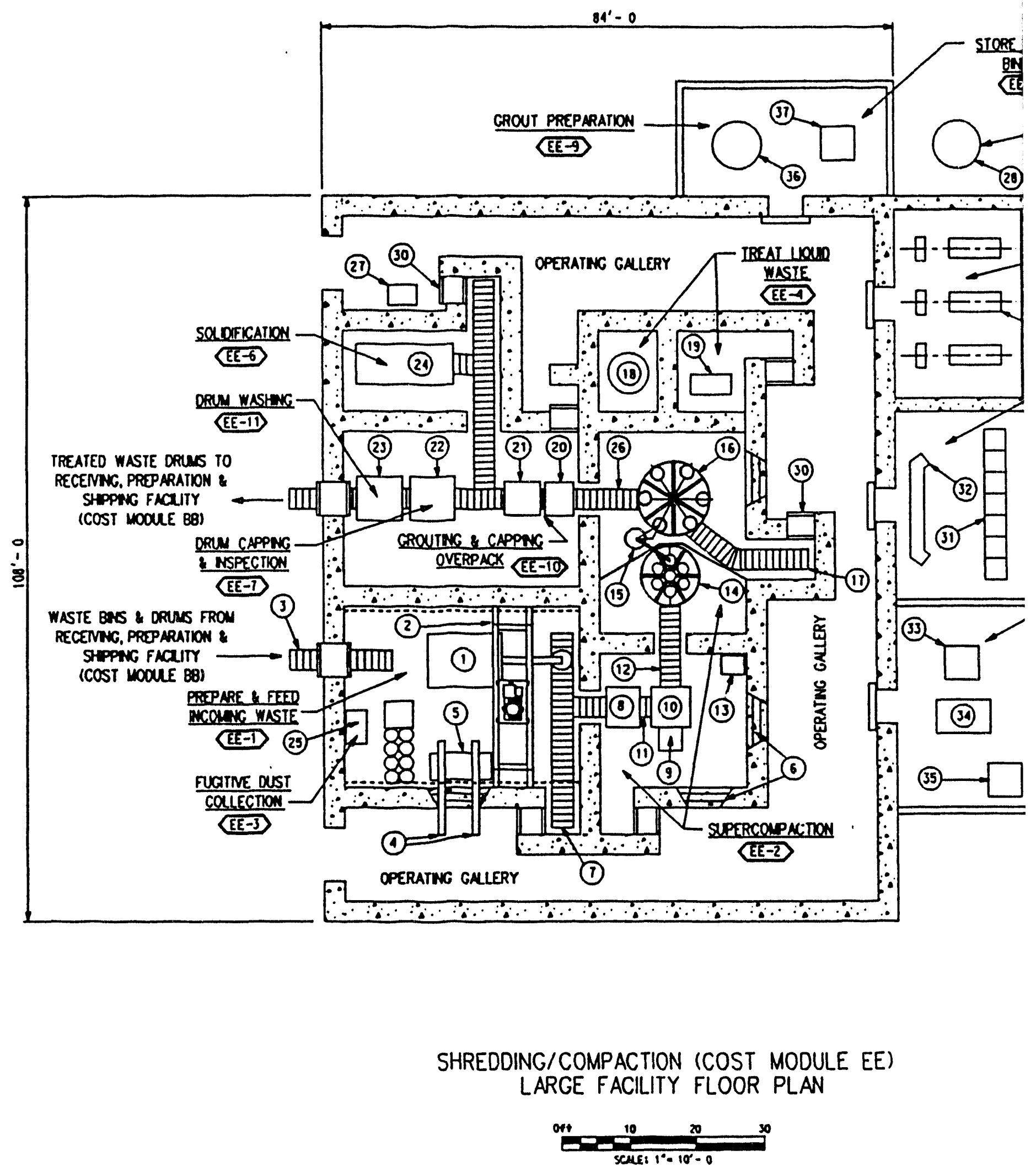

Figure 6-1. GTCC LLW shredding/compaction facility plan (cost module EE). 


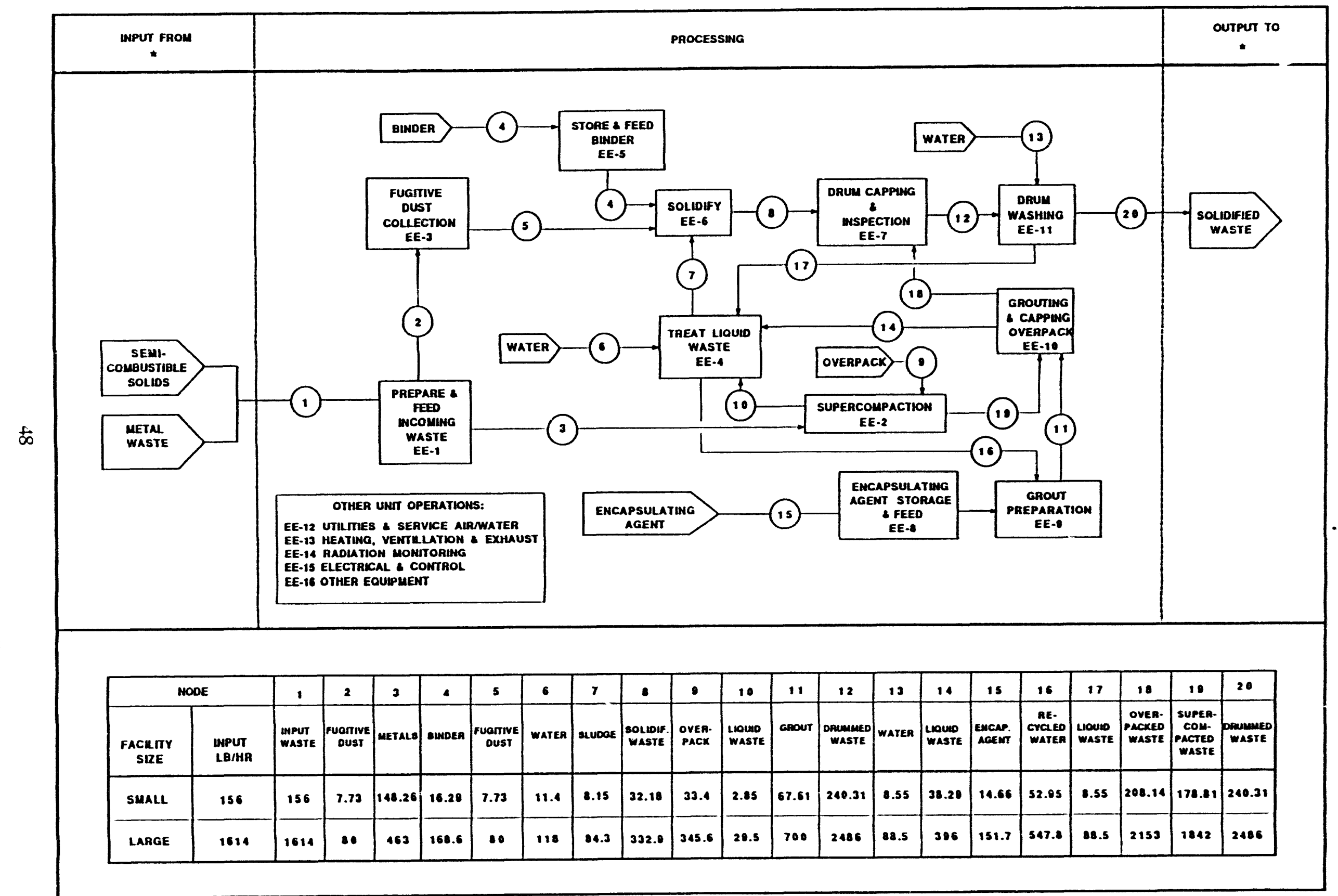

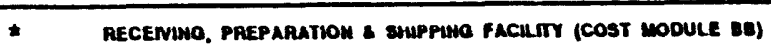

Figure 6-2. Process functional diagram for GTCC LLW shredding/compaction facility (cost module EE). 
The overpacks (85-gal drums) containing compacted waste and 55-gal drums containing solidified waste are the main output from this facility. The package waste is transported to the receiving, preparation, and shipping facility. Treated offgas is discharged into the atmosphere.

\subsection{Cost Bases, Assumptions, and Assessments}

General cost bases and assumptions are given in Appendix A. Facility-specific items are discussed below:

- The major equipment capital cost items include: waste size reduction and preparation (shredders), supercompactor, and solidification units.

- Major equipment capital costs are verified against the purchased costs incurred by a U.S. Navy low-level waste processing facility (Babcock and Wilcox (B\&W) facility at Lynchburg, Virginia) that recently started operation.

- Estimated operating staff are shown in Table 6-1.

- Small and large facility capacities, and unit costs are as shown in Talie 6-2.

- Budgetary cost for the preparation and feed unit is based on vendor quotes for shredders, conveyors, and dust collection equipment. The cost to furnish the size reduction equipment is based upon prices obtained from Komar Industries, Inc.

- Supercompactor prices are based on budgetary quotes from the Stock Equipment Company, Chagrin Falls, Ohio.

- A fully automated solidification unit operation is selected for the facility. This unit cost is quoted by Stock Equipment Company.

\subsection{Cost Summaries}

A cost summary for the GTCC LLW shredding/compacting facility is shown in Table 6-3. A histogram of cost versus capacity is given in Figure 6-3. 
Table 6-1. Estimated operating staff for GTCC LLW shredding/compaction facility (cost module EE).

\begin{tabular}{llcc} 
Unit Operation & \multicolumn{1}{c}{ Description } & Small (FTE) & Large (FTE) \\
\hline EE-1 & Prepare and Feed Incoming Waste & 0.5 & 3 \\
EE-2 & Supercompaction & 0.5 & 4 \\
EE-3 & Fugitive Dust Collection & 0 & 1 \\
EE-4 & Treat Liquid Waste & 0.33 & 2.00 \\
EE-5 & Store and Feed Binder & 0.50 & 2.00 \\
EE-6 & Solidification & 0.33 & 2.00 \\
EE-7 & Drum Capping and Inspection & 0.5 & 2.00 \\
EE-8 & Encapsulating Agent Storage and Feed & 0.33 & 0.60 \\
EE-9 & Grout Preparation & 0.33 & 0.60 \\
EE-10 & Grouting and Caping Overpack & 0.50 & 2.00 \\
EE-11 & Drum Washing & 0.50 & 2.00 \\
EE-12 & Utilities and Service Air/Water & 0.50 & 2.00 \\
EE-13 & Heating, Ventilation and Exhaust & 0.50 & 2.00 \\
EE-14 & Radiation Monitoring - & 0.50 & 2.00 \\
EE-15 & Electrical and Control & 0.50 & 2.00 \\
EE-16 & Other & 1.00 & 3.00 \\
& & 7.32 & 32.20 \\
\hline
\end{tabular}

Table 6-2. Capacities and unit cost for GTCC LLW shredding/compaction facility (cost module EE).

\begin{tabular}{|c|c|c|c|c|c|c|}
\hline $\begin{array}{c}\text { Mixiluie } \\
\text { Cixle }\end{array}$ & $\begin{array}{l}\text { Cost Module } \\
\text { Description" }\end{array}$ & Fucility & 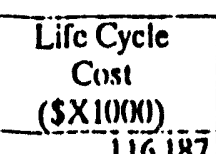 & 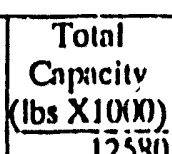 & $\begin{array}{l}\text { Capacity } \\
\text { (Ins/!n })\end{array}$ & 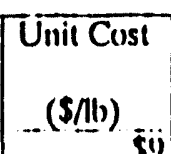 \\
\hline 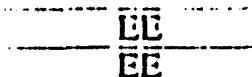 & 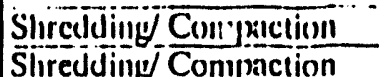 & Simail & $\begin{array}{r}-116,18 \overline{7} \\
345,2, y\end{array}$ & \begin{tabular}{|l}
125360 \\
130153 \\
\end{tabular} & $\begin{array}{r}150 \\
1,614\end{array}$ & \begin{tabular}{|r}
$\mathbf{s i j}$ \\
$\mathbf{5 3}$
\end{tabular} \\
\hline
\end{tabular}


Table 6-3. PLCC estimate summary for GTCC LLW shredding/compaction facility (cost module $\mathrm{EE})$.

\begin{tabular}{|c|c|c|c|}
\hline & $\begin{array}{c}\text { Cost } \\
\text { componest }\end{array}$ & Small ${ }^{\text {Cost }}$ & \\
\hline 1.0 & 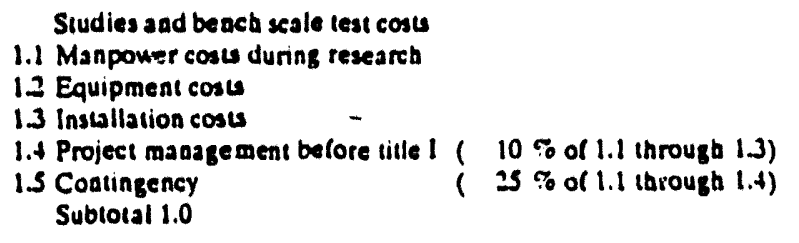 & $\begin{array}{r}\$ 1,950 \\
\$ 100 \\
\$ 300 \\
\$ 233 \\
\$ 546 \\
\$ 3.231\end{array}$ & $\begin{array}{r}\$ 1,950 \\
\$ 100 \\
\$ 300 \\
5235 \\
\$ 646 \\
\$ 3231\end{array}$ \\
\hline 2.0 & 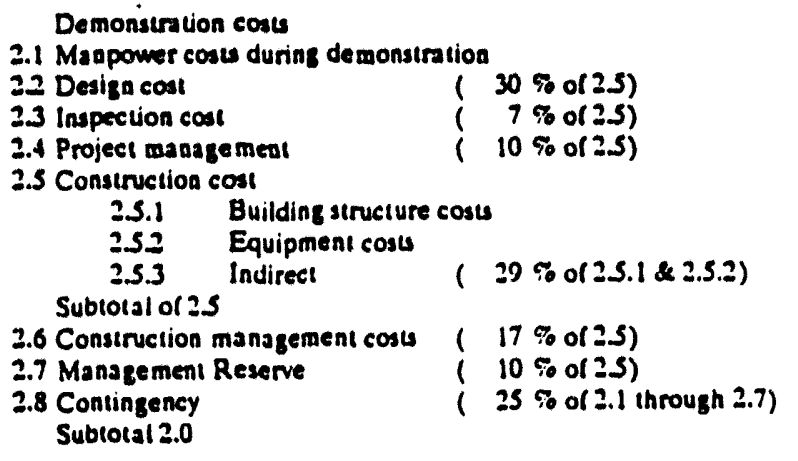 & 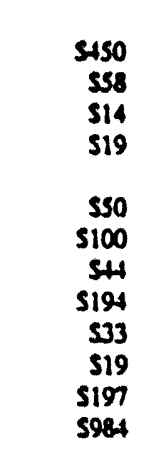 & $\begin{array}{l}\text { s4s0 } \\
\text { ss8 } \\
\text { sit } \\
\text { sig } \\
\\
\text { s50 } \\
\text { sio0 } \\
\text { s4t } \\
\text { s194 } \\
\text { S33 } \\
\text { S19 } \\
\text { s197 } \\
\text { S984 }\end{array}$ \\
\hline 3.0 & 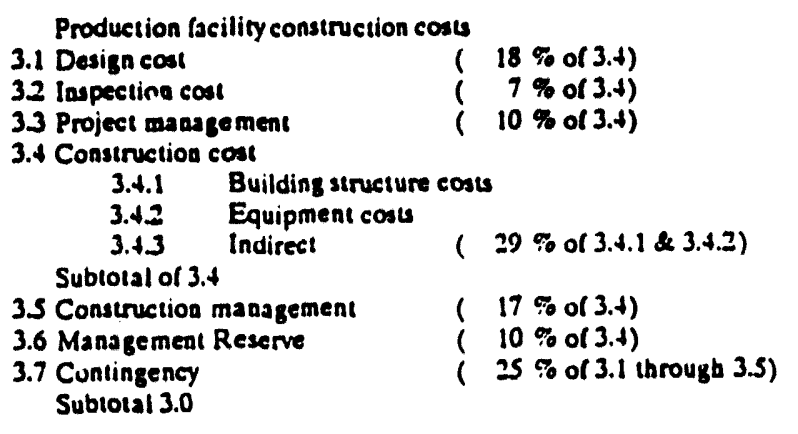 & $\begin{array}{r}\$ 5.768 \\
52.243 \\
53.204 \\
\\
59.519 \\
515.321 \\
57.204 \\
532.044 \\
55.480 \\
53.204 \\
512.185 \\
564.128\end{array}$ & 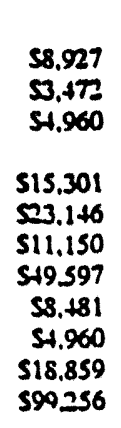 \\
\hline \multirow[t]{2}{*}{4.0} & 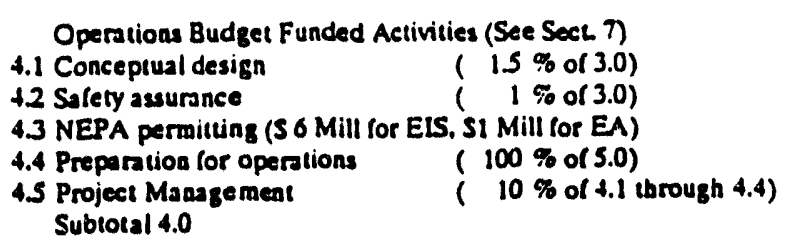 & $\begin{array}{r}5962 \\
56+1 \\
56.000 \\
51.691 \\
5929 \\
S 1020\end{array}$ & $\begin{array}{r}\$ 1.489 \\
\$ 993 \\
S 6,000 \\
s 10.764 \\
\$ 1.925 \\
21.171\end{array}$ \\
\hline & Tolal Initial Cost $(1.02 .0,3.0 \& 4.0)$ & 578.566 & 5124,642 \\
\hline 5.0 & 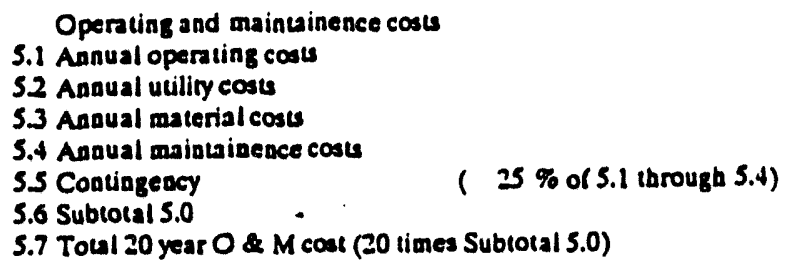 & $\begin{array}{r}\mathbf{S 1 . 0 2 5} \\
\mathbf{S 8 0} \\
\mathbf{S 5 0} \\
\mathbf{S 1 9 8} \\
\mathbf{S 3 3 8} \\
\mathbf{S 1 . 6 9 1} \\
\mathbf{S 3 3 . 8 2 0}\end{array}$ & $\begin{array}{r}S H . S 08 \\
S 176 \\
S 136 \\
S 3.791 \\
\mathbf{S} .153 \\
\mathbf{S 1 0 . 7 6 4} \\
\mathbf{\Omega 1 5 2 8 0}\end{array}$ \\
\hline 6.0 & Decontamination \& Decommissioning & $\mathbf{S 3 , 8 0 1}$ & $\$ 5.337$ \\
\hline 7.0 & ROM Life cycle cosis (20 years operatioa) & $S 116.187$ & 5345,259 \\
\hline
\end{tabular}




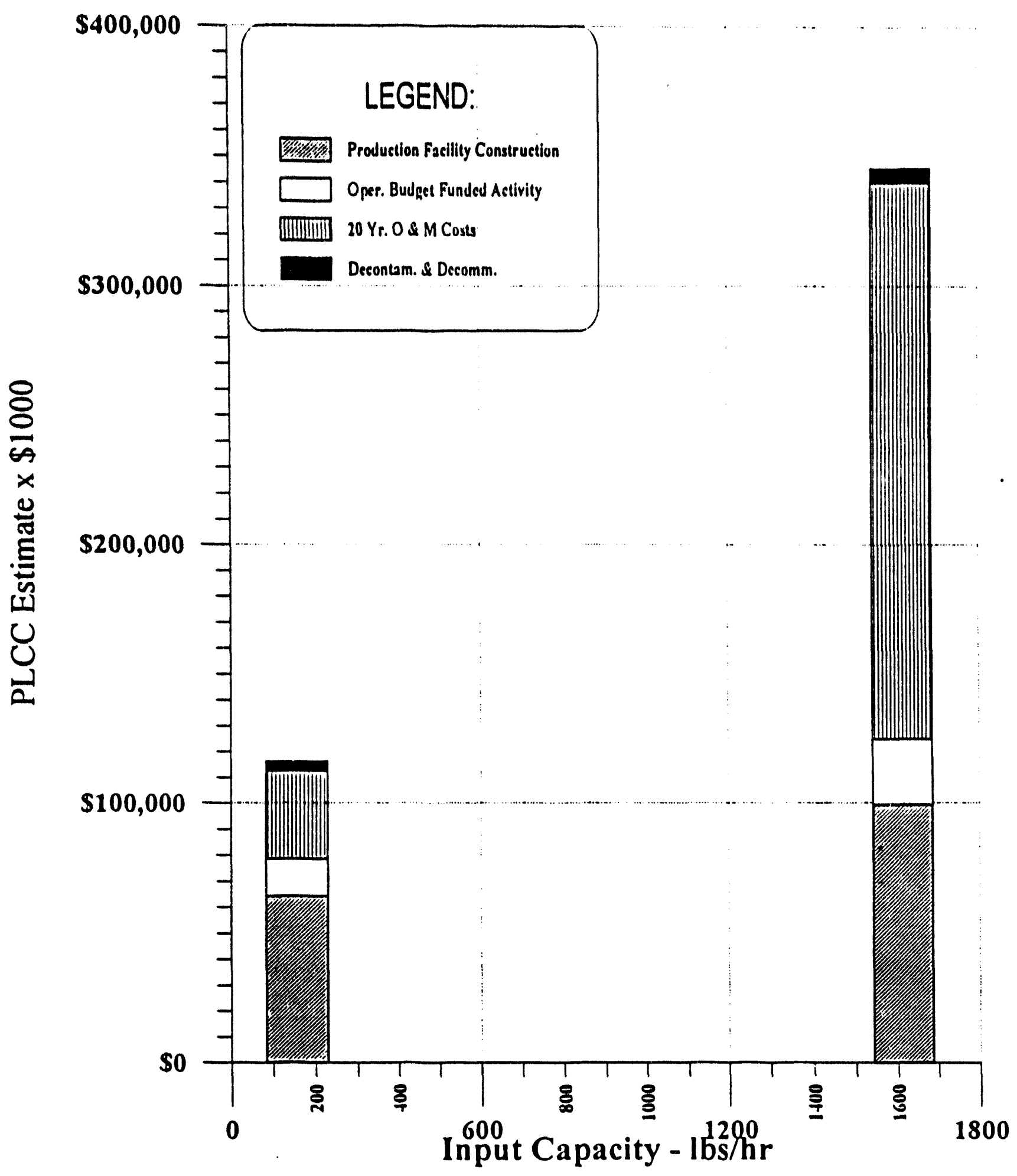

Figure 6-3. Cost versus capacity histogram for GTCC LLW shredding/compaction facility (cost module EE). 


\section{SOLIDIFICATION FACILITY (COST MODULE FF)}

\subsection{Basic Information}

The GTCC LLW solidification facility shown ir. Figure 7-1 comprises 15 main unit operations that incorporate all buildings, systems, processes, equipment, devices, controls and accessories required to solidify the incoming solid waste. The facility must be used either in conjunction with the receiving, preparation, and shipping facility, or constructed next to an existing facility where similar functions are already available.

The facility shreds combustible, semicombustible, and noncombustible waste. The size reduced particles are mixed with a binder to form an encapsulated matrix. The encapsulated matrix is packaged in drums. An additional feature of the facility is grinding and solidification of ion-exchange resins. Unit operations that accomplish the general functions are shown in Figure 7-2.

\subsection{Technical Basis and Assumptions}

\subsubsection{Functional and Operational Description}

The facility receives waste from the receiving, preparation, and shipping facility (cost module BB). The assayed containers, containing GTCC LLW metals, filter media, and cartridge filters, are remotely transferred to a size reduction unit operation, dumped, and fed to the appropriate size reduction device. All empty containers are returned to the receiving, preparation and shipping facility for packaging and disposal or decontamination and reuse. The size reduction unit operation shreds the waste to the desired size and feeds it to the encapsulating unit operation. The shredding device can accept solids up to approximately $1 \mathrm{ft}^{3}$. Solids larger than $1 \mathrm{ft}^{3}$ are size reduced by other techniques such as a plasma torch. The size reduction unit operation also collects and treats any air containing fugitive dust from shredding and related operations. At the encapsulating unit operation, the shredder waste is mixed with an encapsulation agent and packaged into disposal containers.

The facility has remotely operated devices needed for accepting the incoming ion-exchange bead resin waste and mixing it with the encapsulating agent. The assayed containers containing resins are remotely transferred to a dumping and grinding unit operation. In this unit operation the spent resin is dumped into a hopper, water is added to form a slurry mixture, and the resin-slurry mixture is transferred to a grinding device. The grinder reduces resin beads to a powdered form to prevent resin swelling in a solidification matrix. Following grinding, the resin slurry is transferred to the resin solidification unit operation. Sampling of the resin slurry is performed to ensure that all resin is reduced to the specified size.

The solidification unit for resin has remotely operated in-drum solidification assemblies equipped with intake tanks and hoppers for solid slurry and liquid waste. To accomplish the solidification process a drum is placed onto a transfer cart. The cart moves the drum to various fill stations where feeders place solidification agents in the drum. The solidification unit can use either Portland cement or polymers or solidification agents. Next, the cart moves the filled drum to a mixing station where the drum is capped and turnbled to achieve the required mixture. The cart then returns the drum to repeat the filling/mixing step to maximize the fill efficiency. 


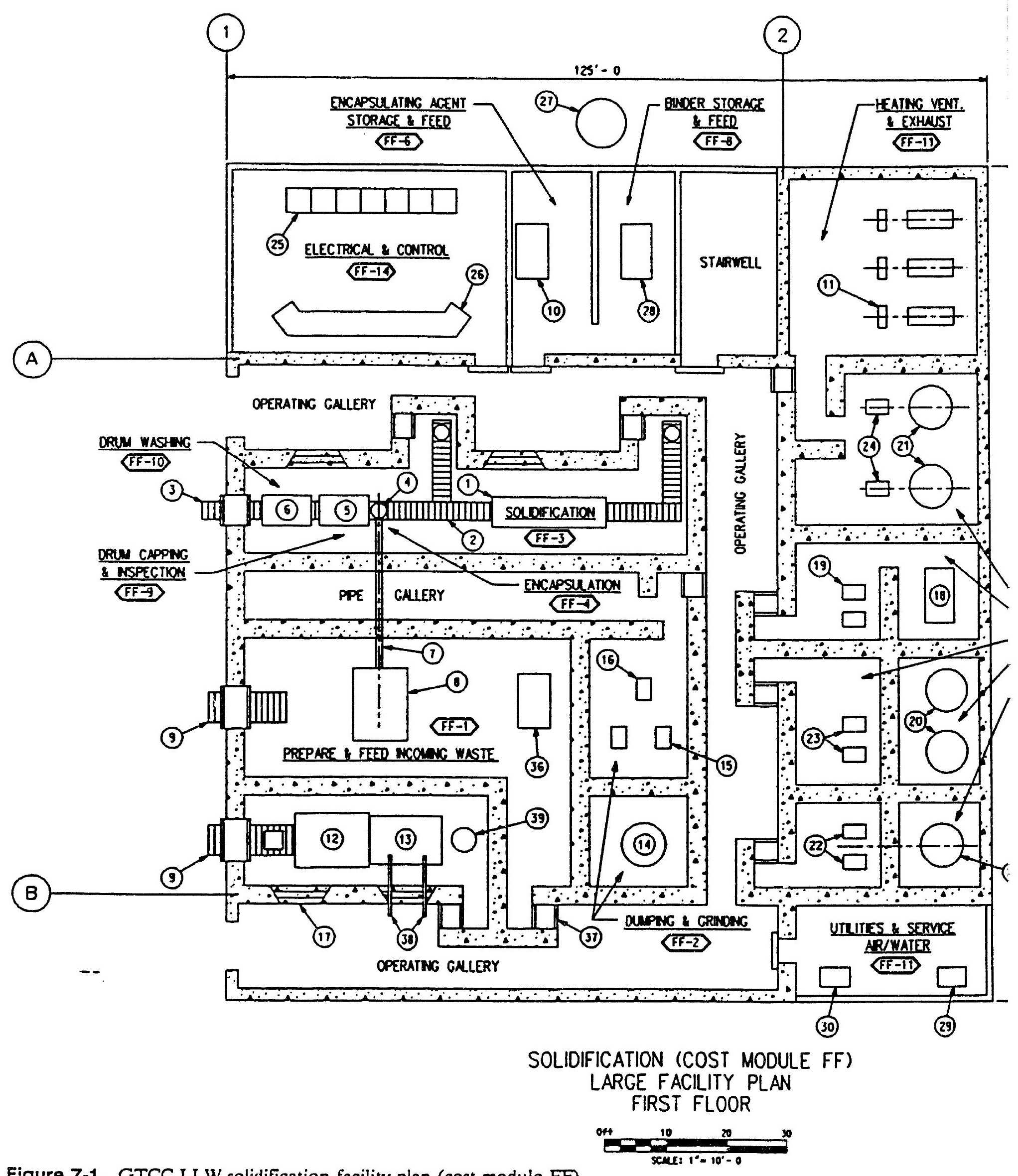

Figure 7-1. GTCC LLW solidification facility plan (cost module FF). 


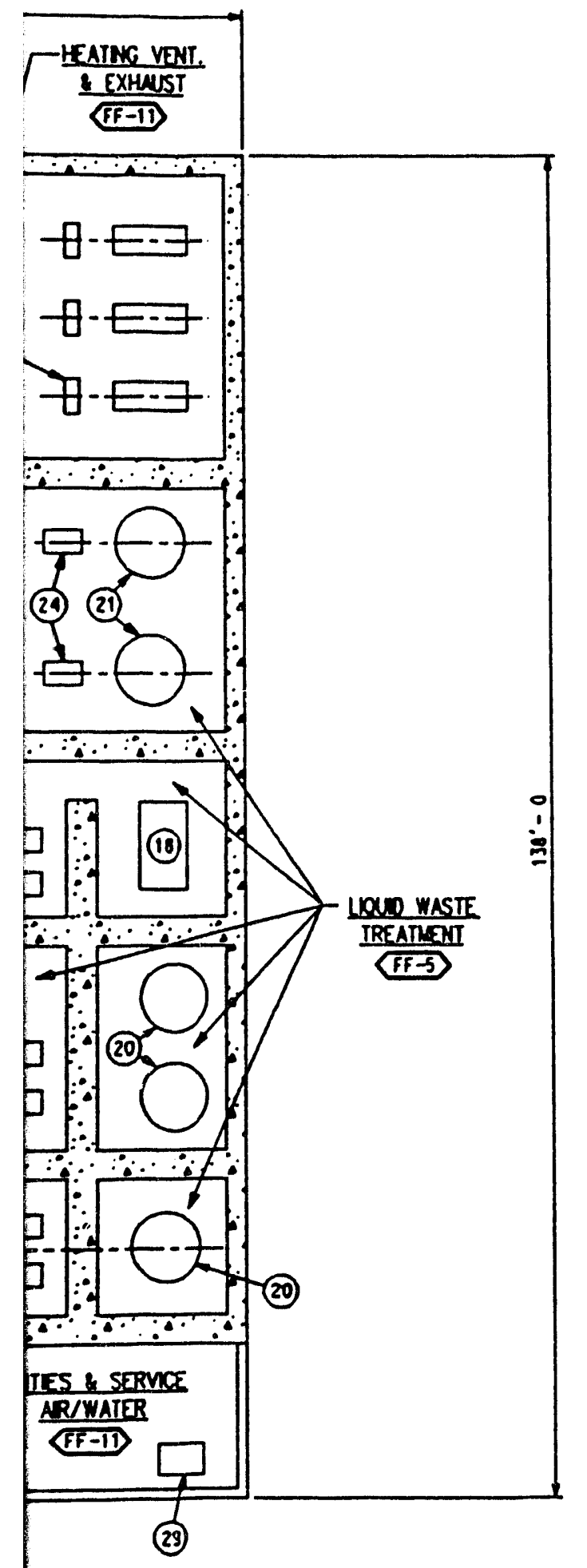

\section{MAJOR EQUIPMENT LIST}

(1) SalofFication UNIT

(2) DRLW CONMEYOR

(3) DRUW OISCHARCE COMveron

(4) keta emcopsuation station

(5) ofUM CAPPER/INSPECTIMO UNIT

(6) orlu vasher

(1) SHFEDOED KeTN CONVEYOR

(3) LTNL SHREDOER

(9) imconing maste converor

(10) Emecossuation fill UnIt

(ii) AIR havaling UNIT

(12) BUK MASTE DUP HOPPER

(13) SIEE REOUCTION UNIT

(14) RESIN OUPP HOPPER

(15) RESIM TRASSFER PUP

(16) RESIN CRINOER

(17) SHIELDING UnNOON (TTP.)

(18) Filtrution Unit

(19) Pup

(20) MASTE TNK

(21) TREATEO MASTE STORUCE TMK

(22) PUP

(23) Pup

(24) Pus

(23) WTTOR CONTRO CENTER

(26) MIM contra PMEL

(27) BINOER SILO

(28) BILER FILL UNIT

(29) COPPESSED AIR PLCXACE

(30) IMSTRUMENT AIR PACXLAE

(3i) concentrate taAK

(32) concentrate pus

(33) BIHOER MIX TAN

(34) BINOER FEED PULP

(35) MASTE PREPARUTION GANTAY RCBOT

(36) OUST COLLCTION UNIT

(37) AIR LOCX ITTP.)

(38) mSter slave muipleator

(39) TRANSFER BIN 


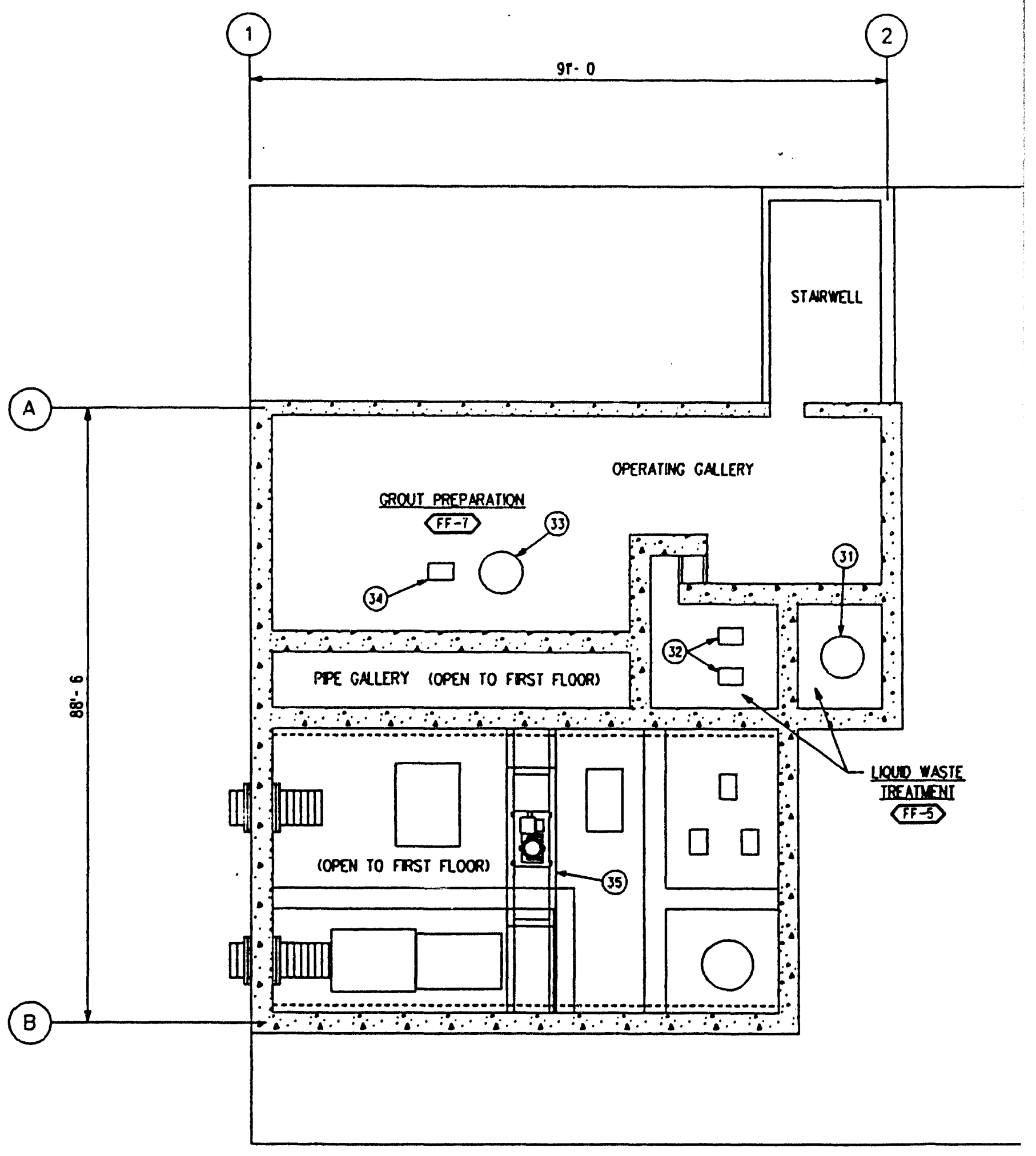

SOLIDIFICATION (COST MODULE FF)

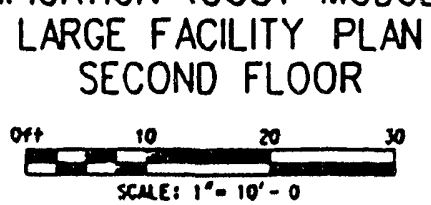

Figure 7-1. (continued). 


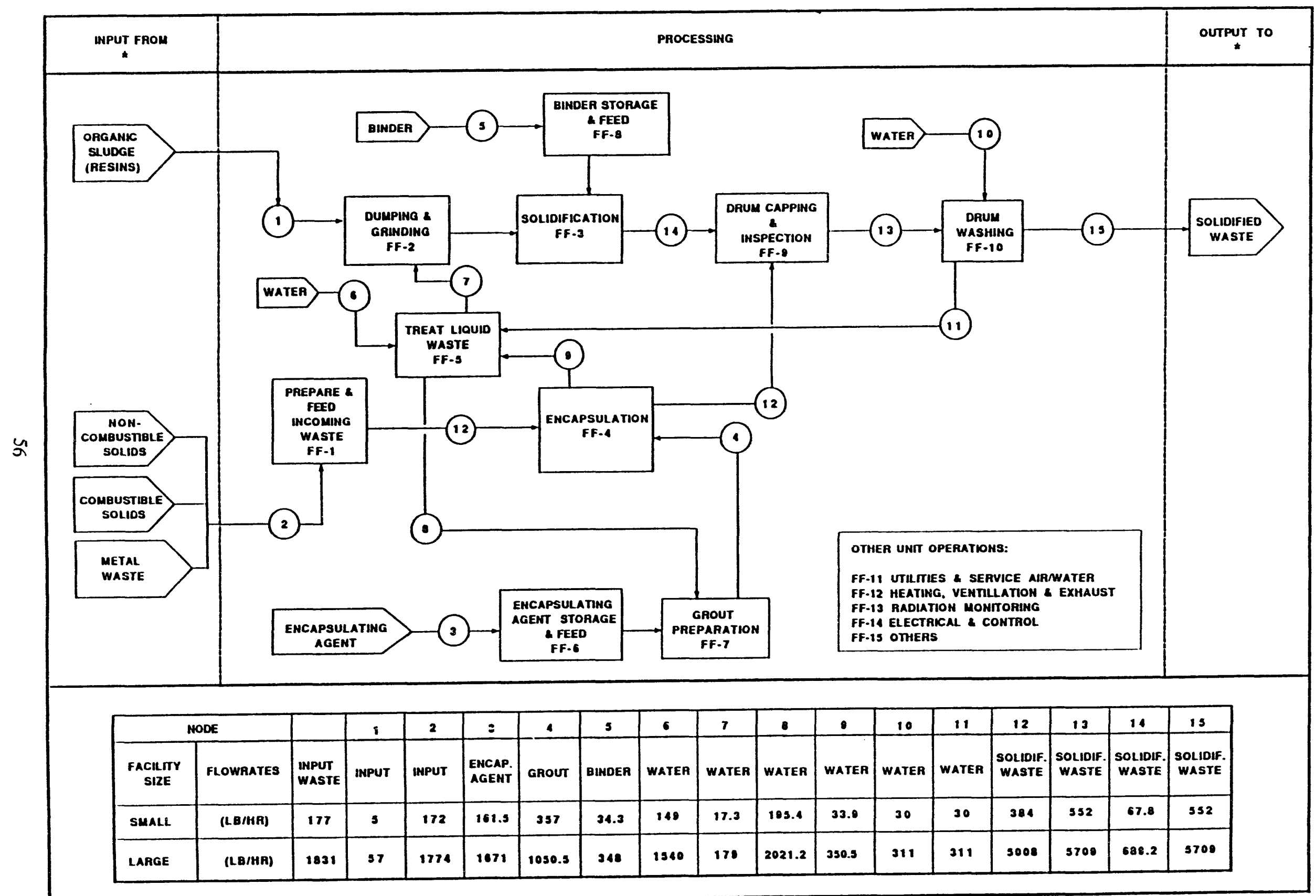

- heceivina. paepara tom a emppina fachitr (COSt module g日)

Figure 7-2. GTCC LLW process functional diagram for solidification facility (cost module FF). 
After proper mixing and capping, the drum is inspected. The drum is then remotely moved to a washing unit operation where loose contamination is removed from the container's outer surface by high pressure spray water jets. This unit operation also collects solidified matrix core samples.

Following drum washing, the filled drums are remotely transferred to a temporary storage vault in the receiving, preparation, and shipping facility (cost module BB).

The facility has three secondary waste streams: low-level liquid waste, dry active waste, and cc.staminated air from the process area. All radioactive and potentially radioactive liquid waste is directed to a liquid waste treatment unit operation, where the waste is recycled by using it to slurry the resin or by mixing it with the solidification agent. Dry active waste includes contaminated housckeeping trash, failed equipment, and ventilation system spent filters. Dry active waste is packaged into drums and sent to another facility for treatment. A ventilation unit operation removes and filters air from radioactive processing areas. The filtered air is discharged to the atmosphere. Spent filter from air filtration system is encapsulated by placing a basket liner inside a 55-gal drum and pouring grout on top to fill the void.

\subsubsection{Facility Integration}

This facility interfaces with the site communication and alarm systems including telephone, evacuation, fire, security alarm, and public address systems. Facility input includes combustible, partially combustible, and noncombustible waste. O\&M material, including personal protective equipment, laboratory material, encapsulation and solidification agents, HEPA filters, and disposal containers, are assumed to be consumable supplies which must be purchased. Facility output includes encapsulated and solidified waste which are shipped to an interim storage facility. Filtered air from the radiation area ventilation is discharged into the atmosphere.

\subsection{Cost Bases, Assumptions and Assessments}

General cost bases and assumptions are given in Appendix A Facility-specific items are discussed below:

- $\quad$ Estimated operating staff is shown in Table 7-1.

- Small and large facility capacities and unit costs are shown in Table 7-2.

- Incoming waste size reduction and preparation (shredders), solidification mixers, and grinders are the major equipment capital cost items.

- Budgetary costs for the preparation and feed unit are based on vendor quotes for shredders, conveyors, and dust collection equipment.

- The cost to furnish the solidification equipment is based on pricas from the Stock Equipment Company.

- The cost to furnish the size reduction equipment is based upon prices obtained from Komor Industries, Inc. 
Table 7-1. Estimated operating staff for GTCC LLW solidification facility (cost module FF).

Unit

Operation

Description

Small

Large

Prepare and Feed Incoming Waste

(FTE)

(FTE)

FF-2

FF-3

Dumping and Grinding

1

Solidification

0.3

4

FF-4

Encapsulation

0.5

2

FF-5

Liquid Waste Treatment

0.5

3

FF-6

Encapsulating Agent Storage and Feed

0.5

2

FF-7

FF-8

Grout Preparation

Binder Storage and Feed

$0.3 \quad 0.6$

FF-9

FF-10

Drum Capping and Inspection

Drum Washing

Utilities and Service Air/Water

FF-11

Heating and Ventilation

FF-12

Radiation Monitoring

FF-14

Electric.sl and Control

FF-15

Other

0.3

0.6

0.5

0.6

$0.5-2$

$0.5 \quad 2$

$0.5 \quad 3$

$0.5 \quad 2$

$1 \quad 3$

$0.5 \quad 3$

14

TOTAL

7.9

35.2

Table 7-2. Capacities and unit cost for GTCC LLW solidification facility (cost module FF).

\begin{tabular}{|c|c|c|c|c|c|c|}
\hline $\begin{array}{l}\text { Module } \\
\text { Code }\end{array}$ & $\begin{array}{l}\text { Cost Modulte } \\
\text { Description }\end{array}$ & Facility & $\begin{array}{c}\text { Life Cycle } \\
\text { Cost } \\
(\$ \times 1000)\end{array}$ & $\begin{array}{c}\text { Totil } \\
\text { Capacity } \\
\text { (Ibs X10(X)) }\end{array}$ & $\begin{array}{l}\text { Calpacity } \\
\text { (IIIsfor) }\end{array}$ & $\begin{array}{l}\text { Unit Cos! } \\
(\$ / 1))\end{array}$ \\
\hline FF & Solidificantion & Small & 273,206 & 14273 & 177 & $\$ 19$ \\
\hline F & Solidification & Lirge & 557,057 & 147652 & 1,831 & $\$ 4$ \\
\hline
\end{tabular}




\subsection{Cost Summaries}

A cost summary for the GTCC LLW solidification facility is shown in Table 7-3. A histogram of cost vs. capacity is given in Figure 7-3. 
Table 7-3. PLCC estimate summar: for GTCC LLW solidification facility (cost module FF).

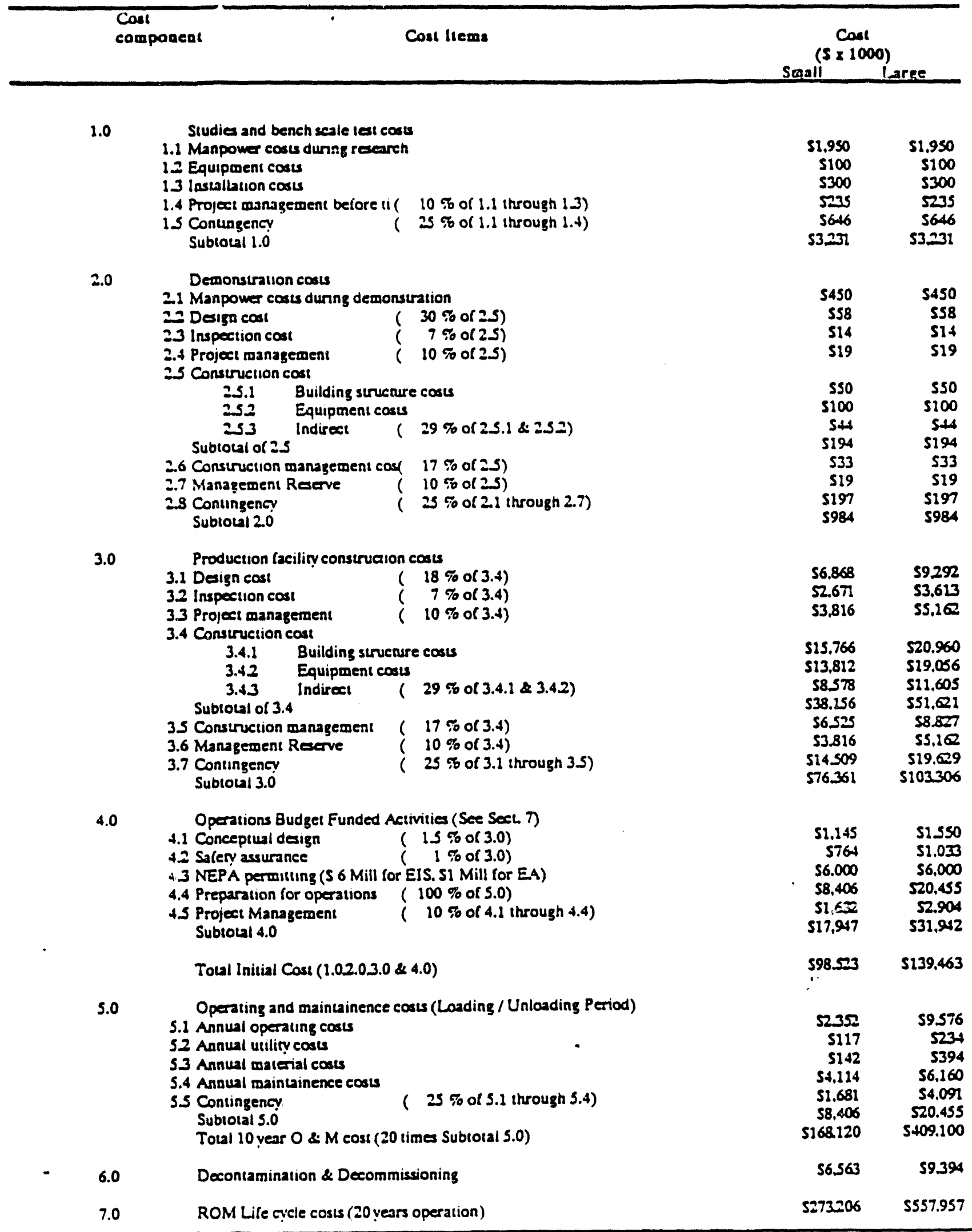




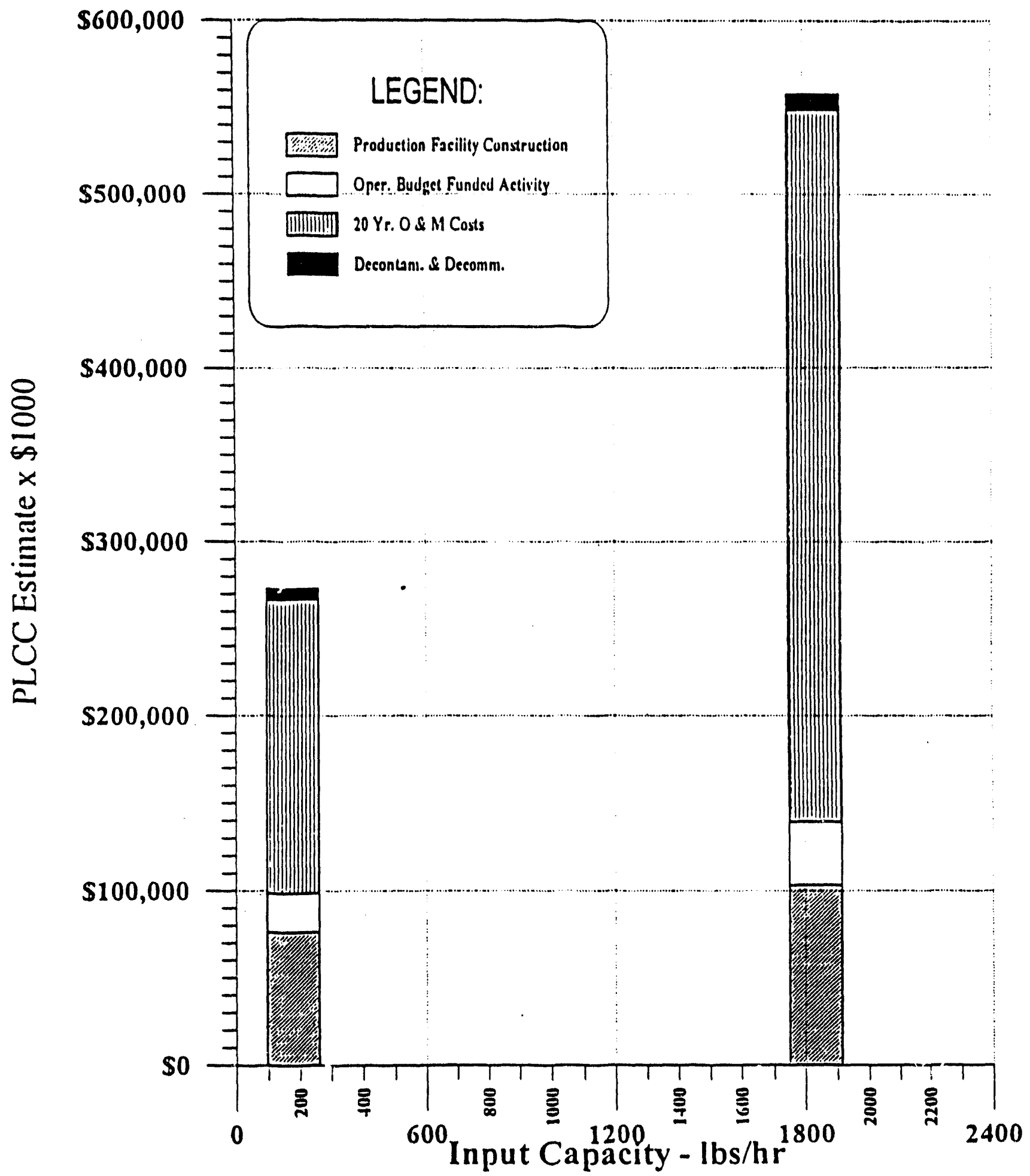

Figure 7-3. Cost versus capacity histogram for GTCC LLW solidification facility (cost module FF). 


\section{VITRIFICATION FACILITY (COST MODULE GG)}

\subsection{Basic Information}

The GTCC LLW vitrification facility, shown in Figure 8-1, processes noncombustible solids such as inorganic sludge, ash, soil, concrete, and other similar material or semicombustible solids such as solidified ion-exchange resins. The facility converts the incoming waste into a leach-resistant rock/glass (vitrified) material. Secondary liquid and gaseous wastes are also treated. Secondary waste treatment by-products, such as offgas scrubber sludge, are either fed to the melter or solidified in drums. The facility must be used in conjunction with the receiving, preparation, and shipping facility, or constructed next to existing facilities where similar functions are already available.

The facility is designed for remote operation and can process solid waste of various shapes and forms. Unit operations that accomplish the general functions are shown in Figure 8-2.

\subsection{Technical Bases and Assumptions}

\subsubsection{Functional and Operational Description}

Operations include an input waste preparation and feed unit that crushes and shreds the incoming waste and transfers it to a melter unit operation. The melter unit operation receives, conditions, and feeds the waste and any sludge that must be vitrified to a vitrification furnace (or melter). Soil is added to the melter by a soil storage and feed unit operation. The furnace melts the soil/waste combination to form a molten slag. A slag cooling and packaging unit is used to receive the molten slag from the melter and cast it into containers. A transport device carries the slag containers to a drum capping and washing unit operation, where loose contamination is removed from the container surface with a high-pressure water spray.

The melter offgas system is equipped with a dry treatment train and a wet treatment train. Dry treatment train consists of high-temperature HEPA filtration units with secondary combustion capabilities (such as ceramic filters). In this train, any combustible constituents are thermally destroyed, and particulates are removed from the offgas stream. An induced air blower moves the conditioned effluent through the wet treatment train that is designed to remove $\mathrm{SO}_{2}, \mathrm{HCl}$, and $\mathrm{NOx}$. A surge tank is provided for offgas retention to reprocess melter exhaust in the event of a process upset.

The sludge from the waste treatment unit is pumped to the melter predryer before vitrification. A solidification unit operation treats any sludge that cannot be vitrified. At the solidification unit, the sludge is mixed with a binder, such as Portland cement, and transferred to a drum. A predetermined ratio is used to produce a stabilized waste. The filled container is moved to a capping and washing unit operation, where the drum is capped and loose contamination is removed from the container surface by high pressure water spray.

The containerized vitrified waste and solidified waste drums are the main output from this cost module. These are ready for processing through radio-assay and final certification, which is included in the facility. 


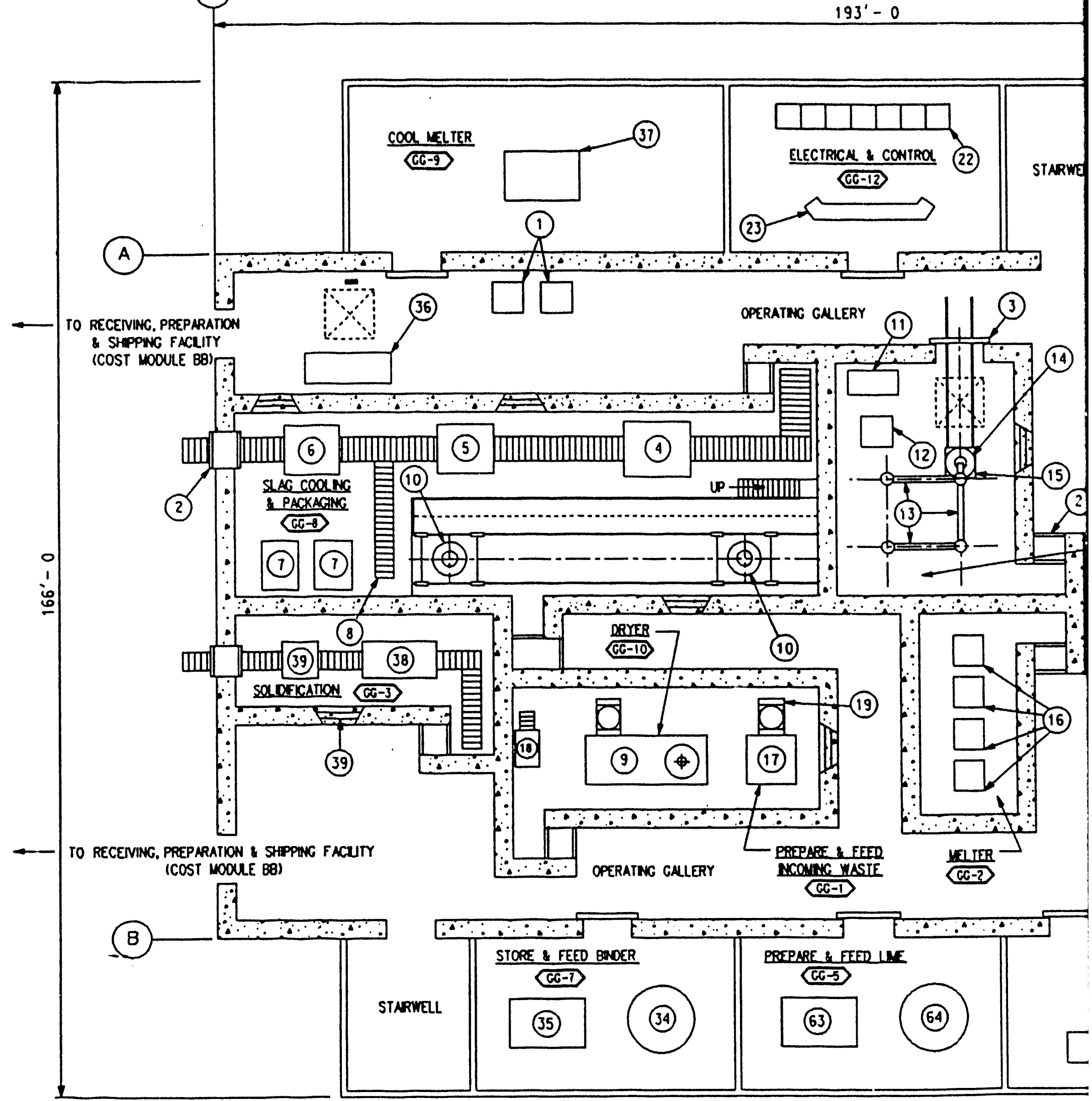

Figure 8-1. GTCC LLW vitrification facility plan (cost module G $)$ ). 


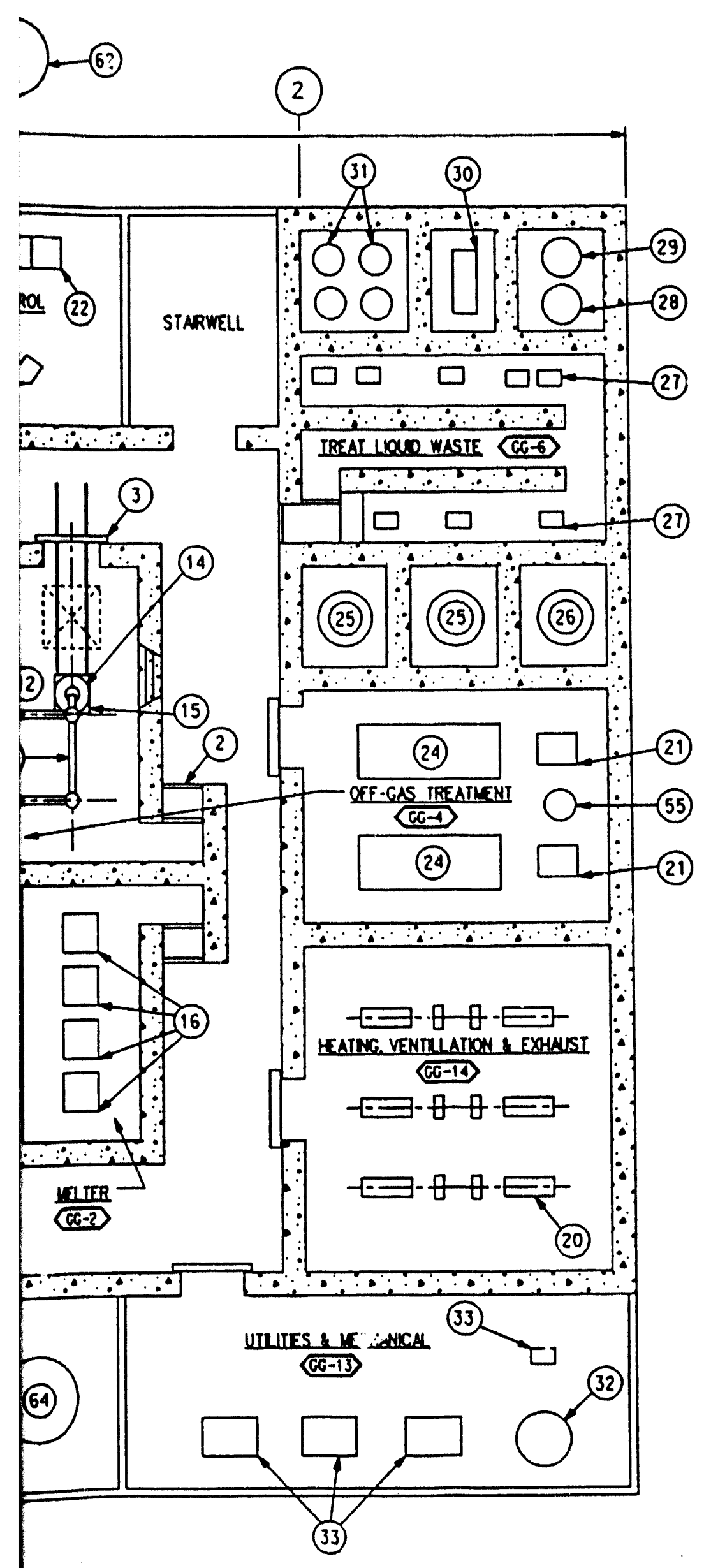

\section{MAJOR EQUIPMENT LIST}

(1) SLAG COOL IMG Blotier

(2) AlR LOCX (TYP.)

(3) SHIELD DOOR

(4) SLAG GROJTING UNIT

(5) SLAG canister capper

(6) canister oecon Unit

(7) canister coo ing chumber

(2) canister conveyor

(9) ORYER

(10) SLag imcot vacum changer

(19) VELTER OXYCEN FEEO CONTROLLER

(12) VELTER IRET AIR bLOTER

(13) FILTER ASH CONVEYOR

(14) ASH DRLW SHIELL CASK

(15) SHIELO CASX CART

(16) vacum PUAP

(17) SHREDOER

(18) OUST COLECTION UNIT

(19) SHFEDOER CONVEYOR

(20) AIR HANOL INCAKEPA FIL TER UNIT

(21) BLOER

(22) wotar contra CENTER

(23) MIIN CONTra. PANeL

(24) VELTER OFF-GAS HEPA FILTER

(25) Treated MaSte taM

(26) IMCONING LIOUID WASTE TNK

(27) PUP

(20) SPENT RESIN TNK

(29) SLWoce thaK

(30) FILTarion UNIT

(3i) ION Exchance UNIT

(32) SERYICE WATER STORACE TANK

(33) AIR COPRESSORS
(34) SO IOIFICATION ACENT Storace silo

(35) ofUM FILL UNIT

(36) cROUT MIXER/PUAP

(37) Kel TER COO INC MATER UNIi

(30) Soloification asselac

(39) SHIELDING VIROON (TMP.)

(40) ORUN CONEYOR

(41) ofundBin CONVEYcR

(12) SIZE REOUCTION TARE \& TOOS

(13) master slave mavipuator

(44) 2 TON Cantry crave

(45) KEL TER DRUN FEEDER

(16) VEL TER BULX FEEOER

(47) BUK MASTE hopPER

(48) If i.P VACUUN CHAJECR

(99) Witemance crave

(50) woRALL/HOIST

(51) CERAMIC PRIIURY FILTERS

52. CERMMIC SECONOARY FILTERS

(53) MIMTEMANCE CRANE

(54) FILTER ELELENT CRUSHER

(55) STACK

(56) DE-MISTER $M$

(57) canoenser

(59) $D E-H I S T E R ~ R$

(59) $R E$ HEATER

(60) SOIL FEEDER

(61) SOIL DAY TANK \& FEED SYSTEM

(62) SOIL SILO \& FEED SYSTEM

63) LIVE PREPARATION STSTEM

(64) LIVE STORACE TNK
VITRIFICATION (COST MODULE GG) LARGE FACILITY PLAN FIRST FLOOR

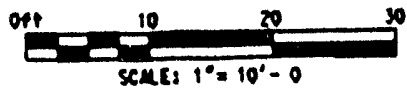




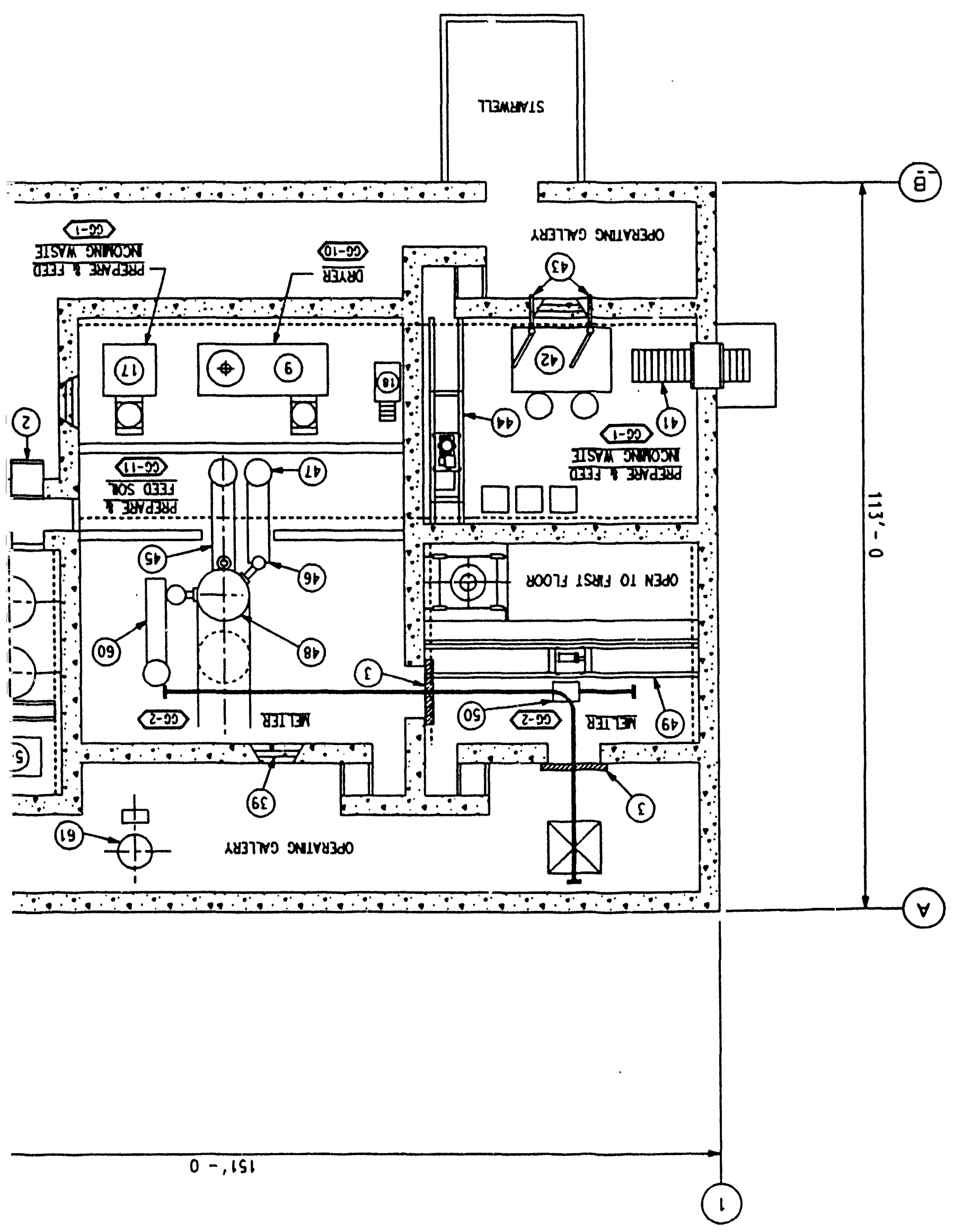



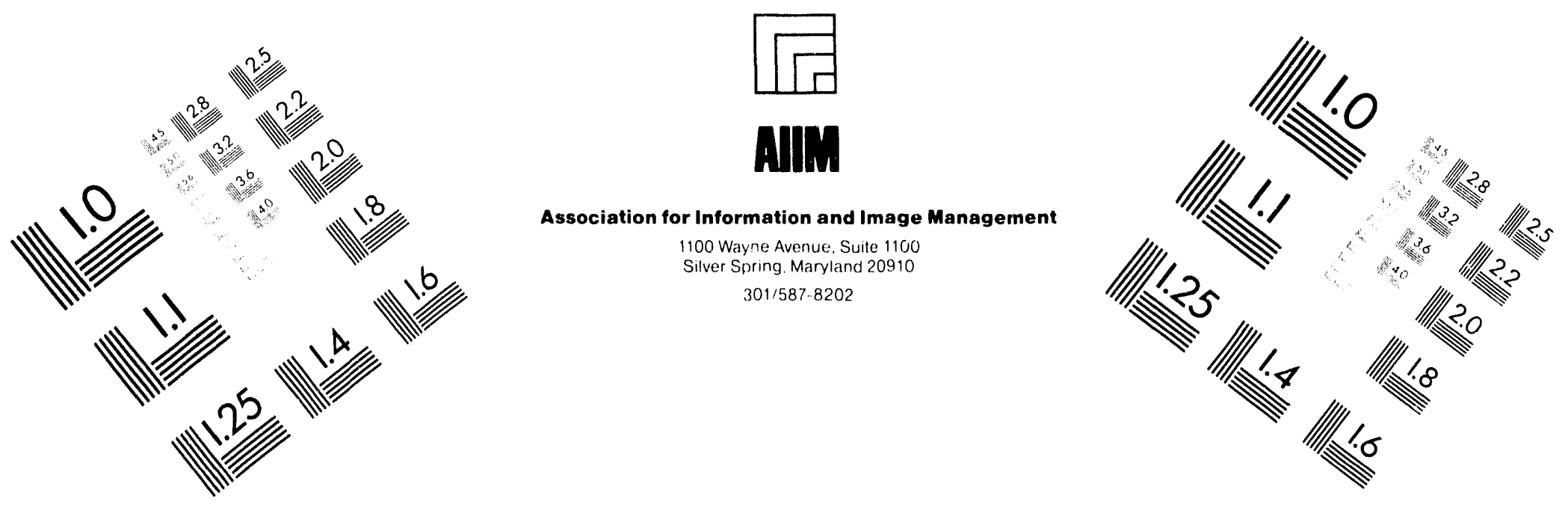

\section{Centimeter}

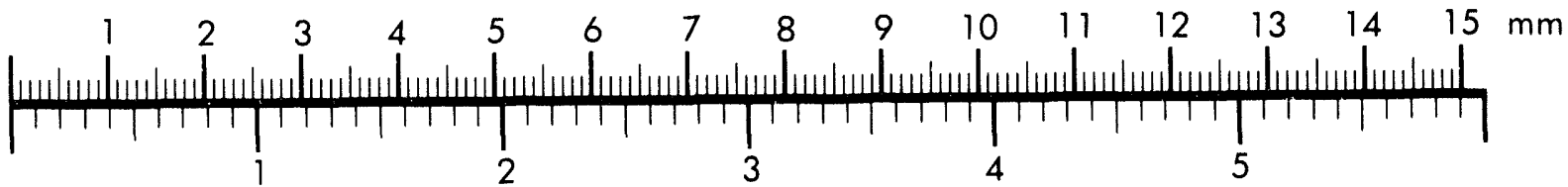

Inches
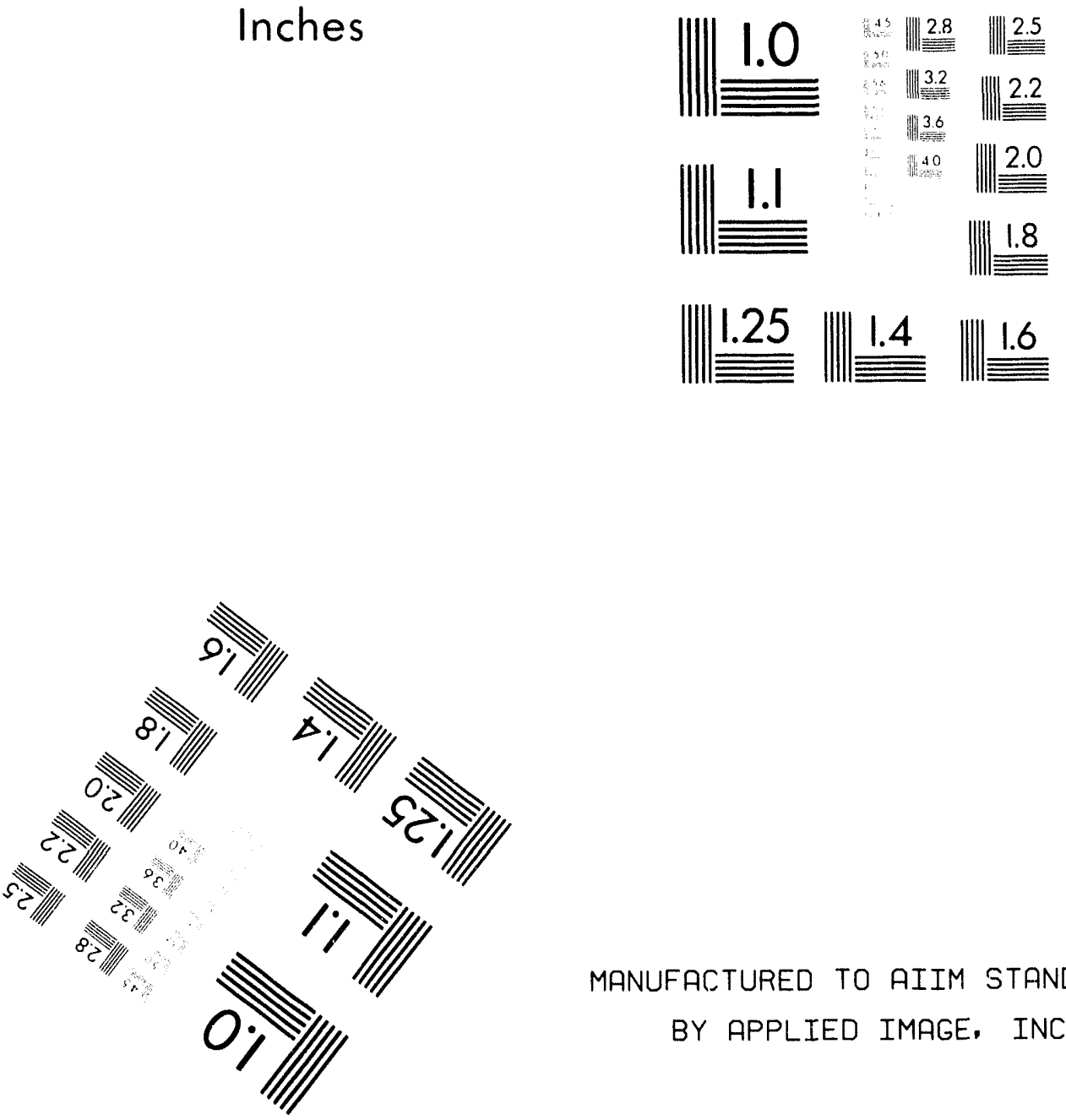

MANUFACTURED TO AIIM STANDARDS

BY APPLIED IMAGE, INC.

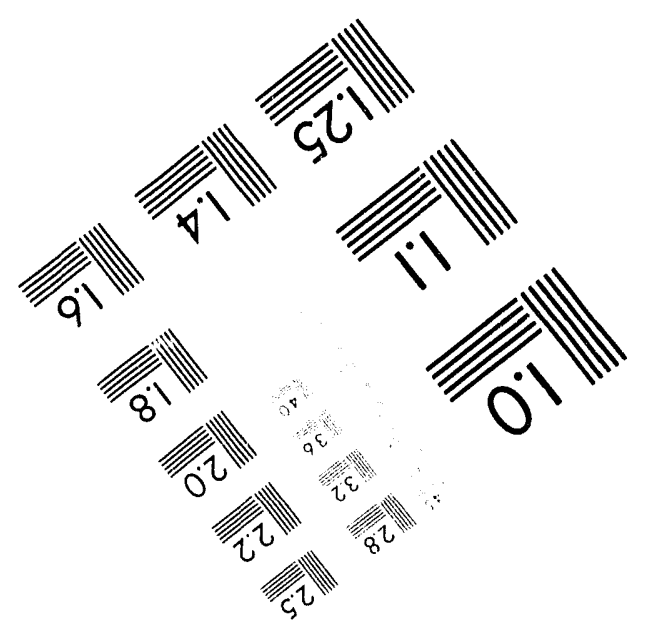



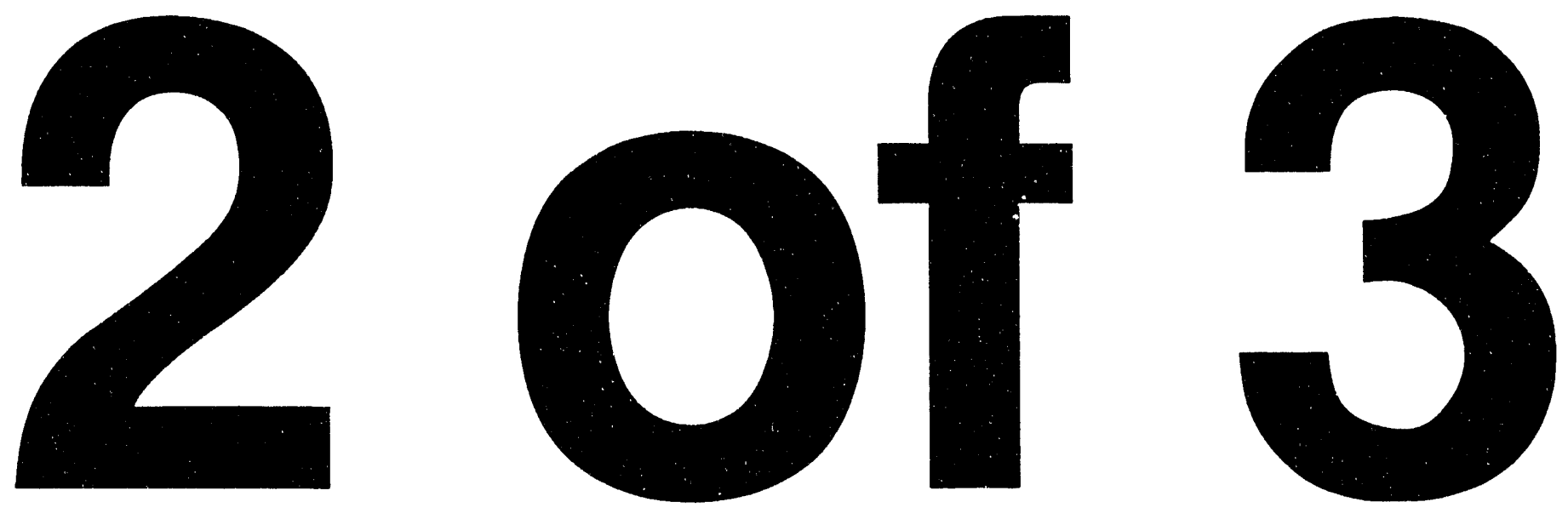
(1) SLAC COOINC BLOTER

(2) AIR LOCK ITYP.)

(3) SHIELD DOOR

(4) slag crouting unit

(5) SLAG CANISTER CAPPER

(6) CANISTER DECON UNIT

(7) canister coOlinc chMGer

(8) CANISTER CONVEYRR

(9) ORYER

(10) SLAG incot VACUM CHAMBER

(11) IEL TER OXYCEN FEED CONIROLLER

(12) LELTER IMET AIR BLOMER

(13) FILTER ASH CONVEYOR

(14) ASH DRUM SHIELD CASK

(15) SHIELD CASK CART

(16) vacuim puts

(17) SHREDOER

(18) DUST COLECTION UNIT

(19) SHREDOER COWVEYRR

(20) AIR HAHOU ING/HEPA FILTER UNIT

(21) BLateR

(22) WOTOR CONIRO CENTER

(23) MIN CONTRO PNEL

(24) MELIER OFF-GAS HEPA FILTER

(25) TREATED MASTE TNA

(26) inconing LIOUIo maste tanK

(27) PUIP

(2B) SPENT RESIN TNK

(29) SLUOCE TNA

(30) FILTRATION UNIT

(31) ION EXCHANGE UNIT

(32) SERvice MATER STORACE tNaK

(33) AIR COAPRESSORS
(34) SOLIOIFICATION AGENT STORAGE SILO

(35) DRUM FILL UNIT

(36) CROUT MIXER/PUNP

(37) Lel ter con ING MATER UNIT

(38) SQ IOIFICATION ASSEMBLY

(39) SHIELDINC YINOON (TYP.)

(40) DRUM COMVYOR

(41) DRUMUBIN CONVEYOR

(42) SIZE REOUCTIOON TABLE \& TOOS

(43) Master sLAVE MaHIPULATOR

(44) 2 TON GANTRY CRAME

(45) MEL TER DRUM FEEDER

(46) LELTER BULK FEEDER

(47) BULX MASTE HOPPER

(48) LeL TER VACUuM chaLeer

(49) maltenance crane

(50) MOMORAIL/HOIST

(51) CERAMIC PRIMURY FIL TERS

(52) CERAMIC SECONOARY FILTERS

(53) MIMITNAHCE CRATE

(54) FILTEF: ELELENT CRUSHER

(55) STACx

(56) DE MISTER \#

(57) CONOENSER

(58) $D E-M I S T E R$ WR

(59) RE-HEATER

(60) SOIL FEEDER

61 SOIL DAY TANK \& FEED SYSTEM

(62) SOIL SILO \& FEED SYSTEM

65) LILE PREPARATION SYSTEM

(64) LILE STORAGE TANX

VITRIFICATION (COST MODULE GG)

LARGE FACILITY PLAN

SECOND FLOOR

ort

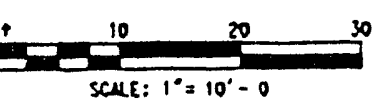




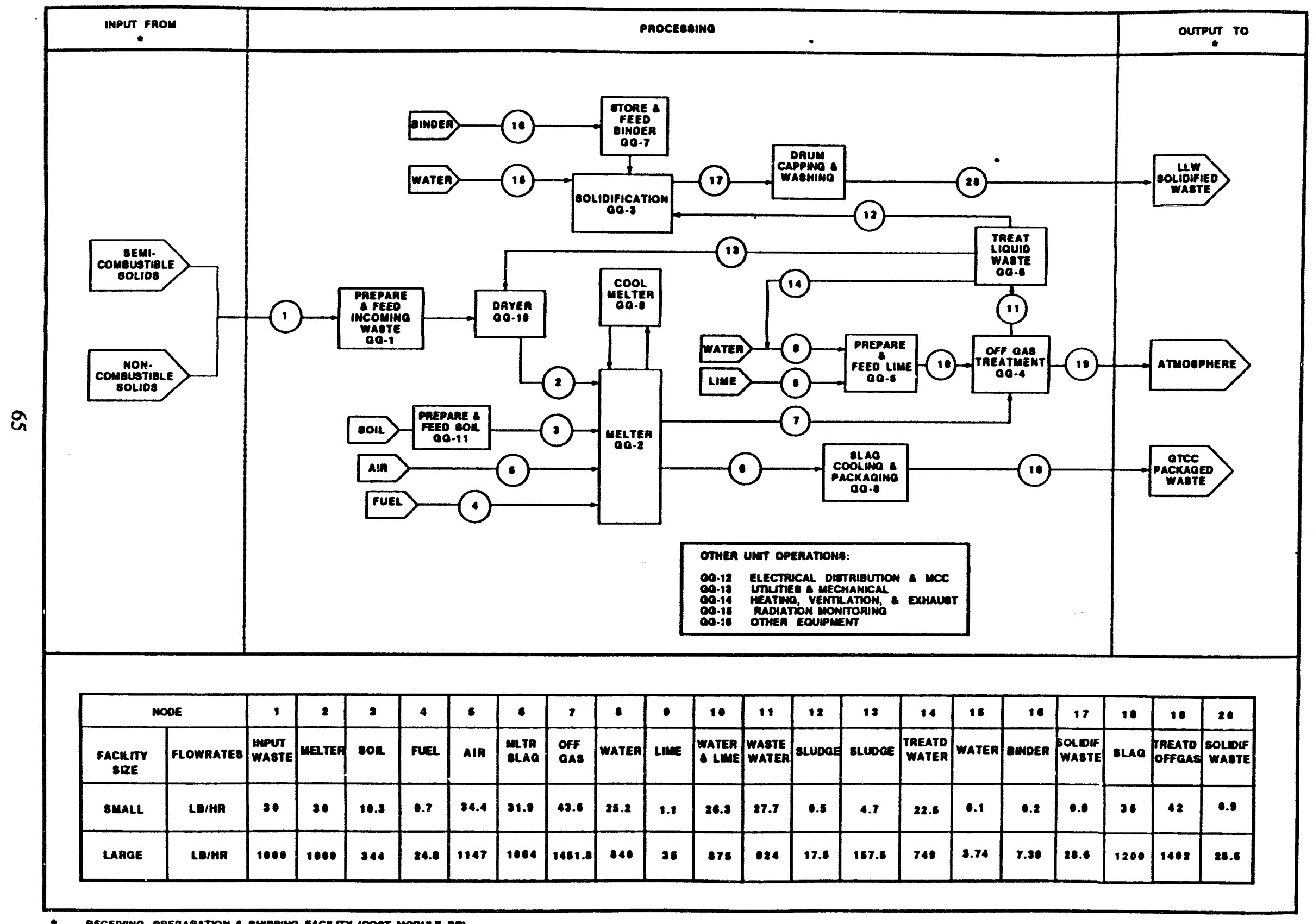

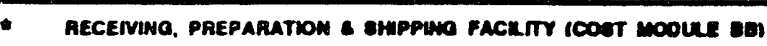

Figure 8-2. Process functional diagram for GTCC LLW vitrification facility (cost module GG). 


\subsubsection{Facility Integ ' ' 'ion}

Major facility inputs include waste from the receiving and preparation facility (cost module BB). Major O\&M purchased materials are consumables such as personnel protective equipment, laboratory material, binder, soil, and disposable containers.

Major facility outputs are containerized vitrified and solidified GTCC LLW which is transported to the receiving, preparation, and shipping facility (cost module $\mathrm{BB}$ ). Treated offgas is discharged into the atmosphere.

\subsection{Cost Bases, Assumptions and Assessments}

General cost bases and assumptions are given in Appendix A. Facility-specific items are discussed below:

- Estimated operating staff are shown in Table 8-1.

- Metal sizing and preparation (shredders), the melter and its offgas, scrubber, and the solidification unit are the major equipment capital cost items.

- Cost for the preparation and feed unit are based on vendor quotes for shredders, conveyors and dust collection equipment.

- $\quad$ Melter prices are based on budgetary quotes received from Retec.

- Callidus Technologies, NGK-Locke, Inc., and Retec provided budgetary quotes for the various offgas scrubbers.

- The selected solidification unit operation is manufactured by Stock Equipment Company, Chagrin Falls, Ohio. This supplier provided a quote based on a unit similar to one sold to the DOE for installation at Savanna River site.

- Small and large facility capacities are shown in Table 8-2.

\subsection{Cost Summaries}

Cost Summaries for the GTCC LLW vitrification facility are shown in Table 8-3. A histogram of cost vs. capacity is given in Figure 8-3. 
Table 8-1. Estimated operating staff for GTCC LLW vitrification facility (cost module GG).

\begin{tabular}{llcc}
\hline $\begin{array}{l}\text { Unit } \\
\text { Description }\end{array}$ & & $\begin{array}{c}\text { Small } \\
\text { (FTE) }\end{array}$ & $\begin{array}{c}\text { Large } \\
\text { (FTE) }\end{array}$ \\
\hline GG-1 & Prepare \& Feed Incoming Waste & 0.5 & 2 \\
GG-2 & Melter & 2.0 & 4 \\
GG-3 & Solidification & 0.5 & 2 \\
GG-4 & Off Gas Treatment & 0.5 & 2 \\
GG-5 & Prepare and Feed Lime & 0.5 & 2 \\
GG-6 & Treat Liquid Waste & 0.5 & 2 \\
GG-7 & Store and Feed Binder & 0.5 & 2 \\
GG-8 & Slag Cooling and Packaging & 1.0 & 2 \\
GG-9 & Cool Melter & 0.0 & 1 \\
GG-10 & Dryer & 0.3 & 4 \\
GG-11 & Prepare and Feed Soil & 1.0 & 2 \\
GG-12 & Electrical Distribution and MCC & 0.5 & 2 \\
GG-13 & Utilities and Mechanical & 0.5 & 2 \\
GG-14 & Heating Ventilation \& Exhaust & 0.5 & 2 \\
GG-15 & Radiation Monitoring & 0 & 1 \\
GG-16 & Other Equipment & 1.0 & 4 \\
& Total & 9.8 & 36 \\
\hline
\end{tabular}

Table 8-2. Capacities and unit costs for GTCC LLW vitrification facility (cost module GG).

\begin{tabular}{|c|l|r|r|r|r|r|}
\hline $\begin{array}{c}\text { Module } \\
\text { Code }\end{array}$ & $\begin{array}{c}\text { Cost Module } \\
\text { Description }\end{array}$ & Facility & $\begin{array}{c}\text { Life Cycle } \\
\text { Cost } \\
(\$ X 1000)\end{array}$ & $\begin{array}{c}\text { Total } \\
\text { Capacity } \\
\text { (lbs X1000) }\end{array}$ & $\begin{array}{r}\text { Capacity } \\
\text { (lbs/hr) }\end{array}$ & $\begin{array}{c}\text { Unit Cost } \\
(\$ / 1 b)\end{array}$ \\
\hline GG & Vitrification & Small & 475,523 & 2419 & 30 & $\$ 197$ \\
\hline GG & Vitrification & Large & $1,028,949$ & 80640 & 1,000 & $\$ 13$ \\
\hline
\end{tabular}


Table 8-3. PLCC estimate summary for GTCC LLW vitrification facility (cost module GG).

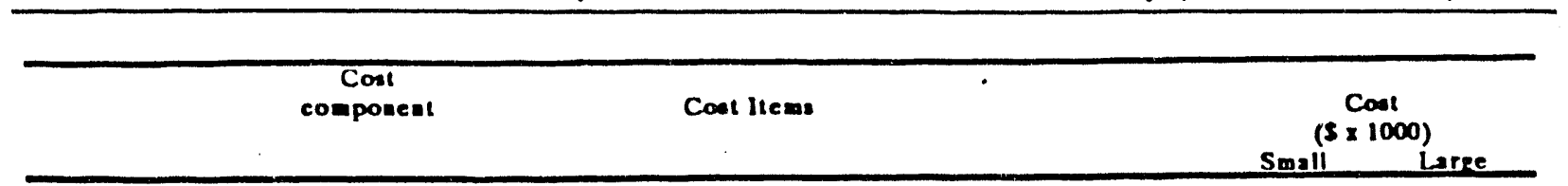

1.0

Studies and bench scale test costs

1.1 Manpower costs during research

12 Equipment costs

13 Installation costs

1.4 Project management before title I ( 1090 of 1.1 througb 1.3)

is Contingency

( $25 \%$ of 1.1 tbrougb 1.4)

Sublotal 1.0

\begin{tabular}{|c|c|}
\hline 53,600 & $\mathbf{S 3 , 6 0 0}$ \\
\hline SESO & 2850 \\
\hline 5650 & 5650 \\
\hline SASO & 5450 \\
\hline 51238 & 5123 \\
\hline 56.188 & 56,18 \\
\hline 22,400 & 20,400 \\
\hline 5167 & S5S \\
\hline 539 & 5129 \\
\hline 556 & 518 \\
\hline 580 & 518 \\
\hline $\mathbf{S 3 5 0}$ & 51.2 \\
\hline $\mathbf{S 1 2 5}$ & 541 \\
\hline ssss & 51.8 \\
\hline 595 & 53 \\
\hline 556 & 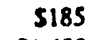 \\
\hline $\mathbf{S 8 4 2}$ & 51.4 \\
\hline$\$ 4,210$ & 57,01 \\
\hline
\end{tabular}

Demonstration costs

2.1 Maspower costs during de monstration

22 Design coul

2.3 Inspection cost

2.4 Project manage meat

( $30 \%$ of 2.5 )

25 Construction cost

$(7 \%$ of 2.5$)$
$(10 \%$ of 2.5$)$

$\begin{array}{ll}2.5 .1 & \text { Building structure costs } \\ 2.52 & \text { Equipment costs } \\ 2.5 .3 & \text { Indirect }\end{array}$

Subtotal of 2.5

2.6 Construction management costs ( 17 \% of 2.5)

2.7 Managemeat Reserve ( $10 \%$ ol 2.5)

2.8 Contingency

( 2550 of 2.1 ibrough 2.7 )

Subtolal 2.0

$\$ 4210$

57,016

Production facility constuction costs

3.1 Design cost

( 1890 of 3.4 )

32 Inspection cost

( 790 of 3.4 )

( $10 \%$ of 3.4 )

512.148

$\$ 4.724$

$\$ 6,749$

523.964

59,320

3.4 Construction cost

517,386

534,931

515.172

3.42 Equipmeot costs

3.4.3 Indirect

$(29 \%$ of $3.4 .1 * 3.12)$

Subtotal of 3.4

3.5 Construction management

$(17 \%$ of 3.4$)$

3.6 Management Reserve

( $10 \%$ of 3.4 )

3.7 Contingency

( $25 \%$ of 3.1 througb 3.5 )

$\$ 67,489$

511,541

$\$ 6.749$

525.663

Sublotal 3.0

$\$ 135.063$

513,314

Operations Budget Funded Activities (See SecL 7)

4.1 Conceptual design

( $1.5 \%$ of 3.0$)$

42 Safety assurance

( $1 \%$ of 3.0$)$

4.3 NEPA permilting ( $\$ 6$ Mill for EIS, $\$ 1$ Mill for EA)

4.4 Preporation for operations ( $100 \%$ of 5.0 )

4.5 Project Management (10\% of 4.1 through 4.4)

Subtotal 4.0

Toul Initial Cost $(1.02 .0,3.0 \& 4.0)$

$\$ 12,908$

$\mathbf{5 0 2 9 8}$

229,930

5133,136

$\$ 22,766$

513.314

550,625

$\$ 266,439$

$\mathbf{2 0 2 6}$

$\mathbf{S 1 , 3 5 1}$

$\$ 3.997$

$\$ 6,000$

$\$ 14,833$

$\mathbf{5}, 421$

52,664

$\$ 6,000$

$\$ 33,858$

$\$ 4,652$

12,092

551.171

Operating and maintainence costs (Loading / Unloading Period)

Operating and maintai

52 Annual utility costs

S.3 Annual material costs

5.4 Annual maintainede costs

5.5 Contingency

( $25 \%$ of 5.1 througb 5.4 )

5.6 Subtotal 5.0

Subtolal 5.0 )

$\mathbf{S 3} 30,814$

5.7 Total 20 year O \& M cost (20 times Subtotal 5.0)

6.0 Decontamination \& Decommissioning

$\mathbf{S 2 , 7 4 4}$

5139

$\mathbf{S 3 7 9}$

$\mathbf{5 8 , 6 0 4}$

$\mathbf{2}, 967$

$\$ 14,833$

$\mathbf{2 9 6 , 6 6 0}$

$\$ 10,080$

5404

5834

$\mathbf{S 1 5 , 7 6 8}$

56,772

$\mathbf{5 3 3 , 8 5 8}$

$\$ 677,160$

$56,771 \quad 520,975$

ROM Lile eycle costs (20 years operation)

$\$ 475,523$

$\$ 1,028,949$ 


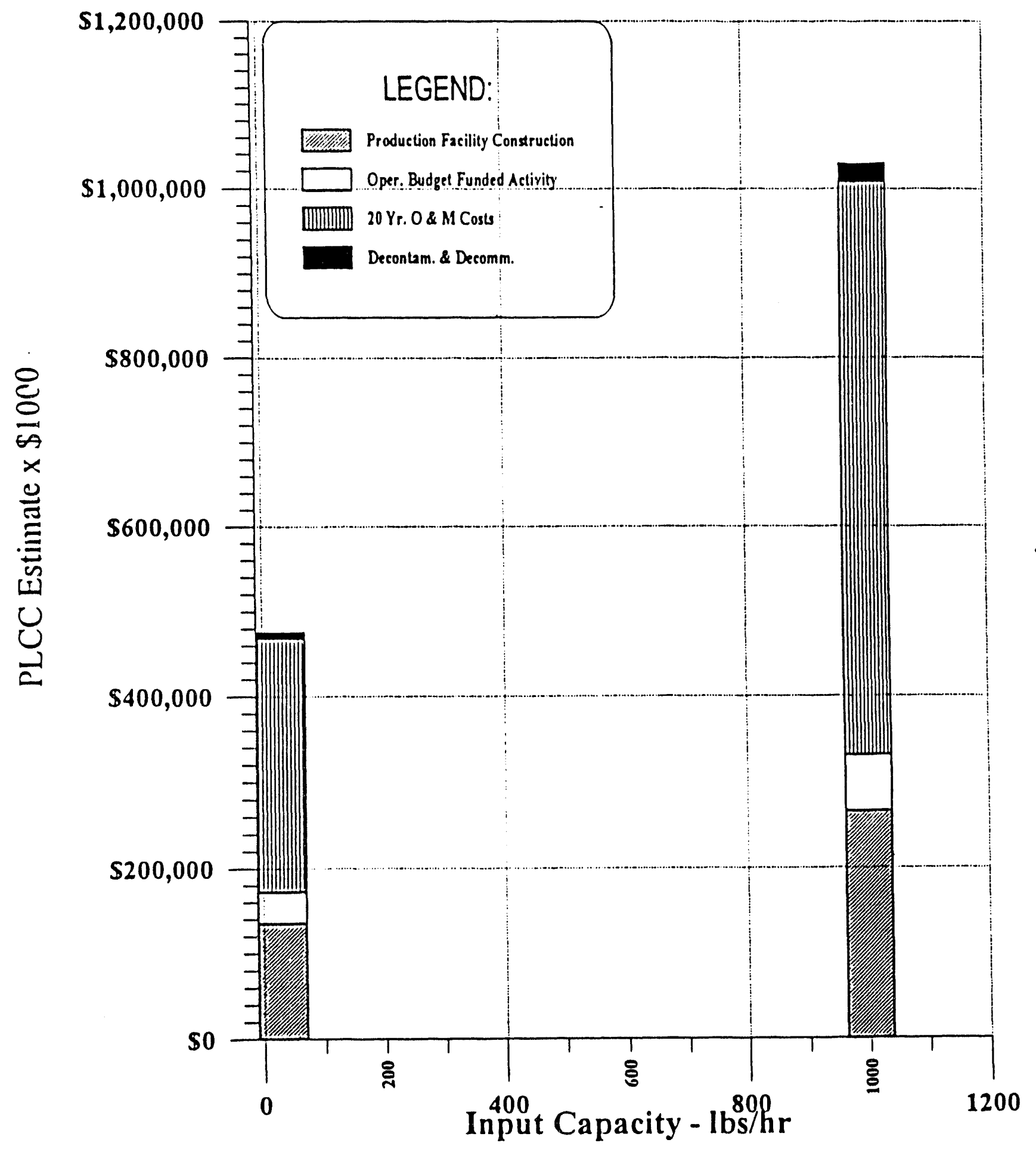

Figure 8-3. Cost versus capacity histogram for GTCC LLW vitrification facility (cost module GG). 


\section{WET-AIR OXIDATION FACILITY (COST MODULE HH)}

\subsection{Basic Information}

The wet-air oxidation (WAO) facility, shown in Figure 9-1, is designed to treat combustible and semicombustible GTCC LLW that is not suitable for direct disposal. The unit operations for the wetair oxidation facility are shown in Figure 9-2.

The facility must be used either in conjunction with receiving, preparation, and shipping facility, or constructed next to existing facilities where similar functions are already in place.

The facility comprises 16 main process unit operations designed to reduce the volume of incoming waste. An advantage of WAO is that it operates at considerably lower temperatures than incineration. The process produces a much cleaner offgas than high temperature thermal processes and does not require a secondary combustion chamber, an electrostatic precipitator, or an acid-gas neutralization system. This facility is designed to process combustible and semicombustible waste such as organic liquids and sludges, ion exchange resins, activated carbon, wood, paper, plastics (PVC and polyethylene) and solvent contaminated rags. The facility is not designed to handle metallic waste. The GTCC LLW processed in this facility requires the use of remote handling equipment.

\subsection{Technical Bases and Assumptions}

\subsubsection{Functional and Operational Description}

A feed pretreatment unit operation reduces the size of the feed to less than $5 \mathrm{~mm}$. in diameter (100\% passing through a Number 4 mesh screen), and conveys the solids to a storage bin. Water and chemicals are added to a feed preparation bin to produce a slurry. The slurry is conveyed to the WAO reactor.

The WAO process oxidizes the organic and other combustible material contained in the feed slurry. The process begins by charging the reactor with a known mass of input waste in slurry form. The contents are then brought to the operating temperature and pressure, and oxygen is introduced to the reactor to start the oxidation reaction. The $\mathrm{pH}$ is controlled by the addition of caustic during the oxidation stream catalyst. Nitrogen is also added to the reactor to control process parameters. The process typically operates in the $230-315^{\circ} \mathrm{F}$ range. Typical operating pressures are in the 300 p.s.i. range depending on the characteristics of the feed. Liquid waste is passed through a strainer and is pumped to a holding tank. The liquid waste, containing dissolved solids, is fed to a concentrator unit operation that concentrates the dissolved solids.

The concentrator distills water from the liquid waste which is collected in a condenser and returned to the slurry tank for reuse later. Solids are concentrated to approximately $25 \%$, and then are transferred to a solidification unit operation. The concentrated liquid contains salts (i.e. $\mathrm{NaCl}$ ) water, ash, radioactive compounds, and traces of low molecular weight organics.

The concentrated waste is converted to a solid matrix by a solidification unit operation. After proper mixing, the drum is temporarily stored for curing and then remotely moved to a capping and washing unit operation where it is capped. Loose contamination is removed from the container outer surface by high pressure spray water jets. This unit operation also provides for sample collection. 
$172^{\circ}-0$

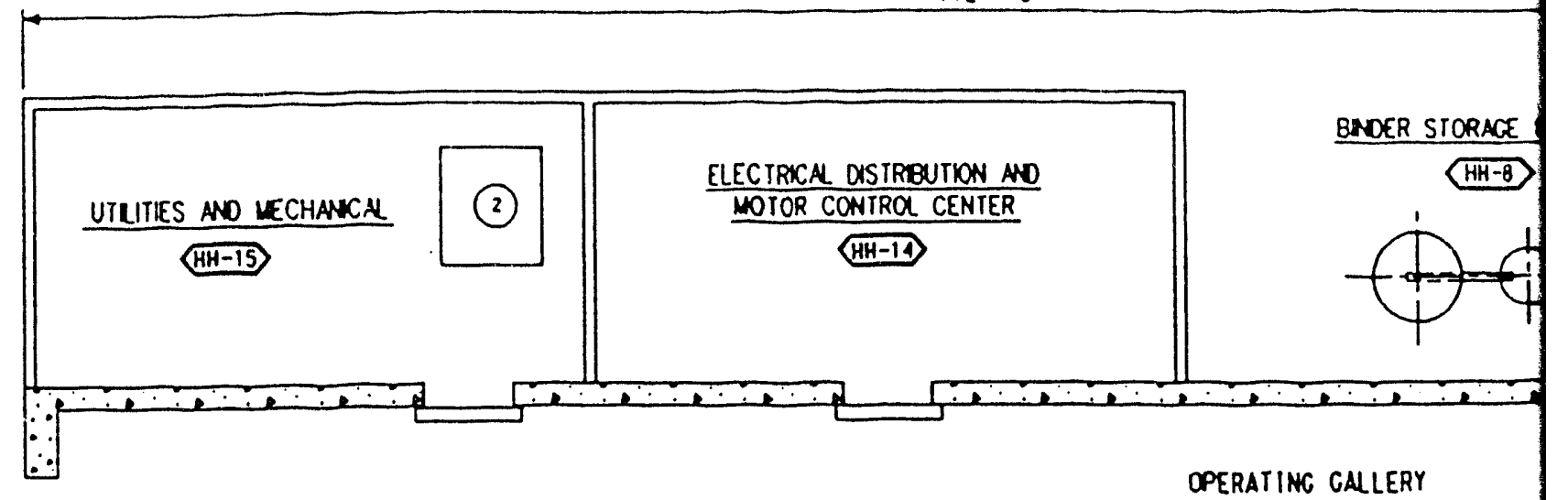

- TO RECEIVING. PREPARATION \& SHIPPING FACILITY

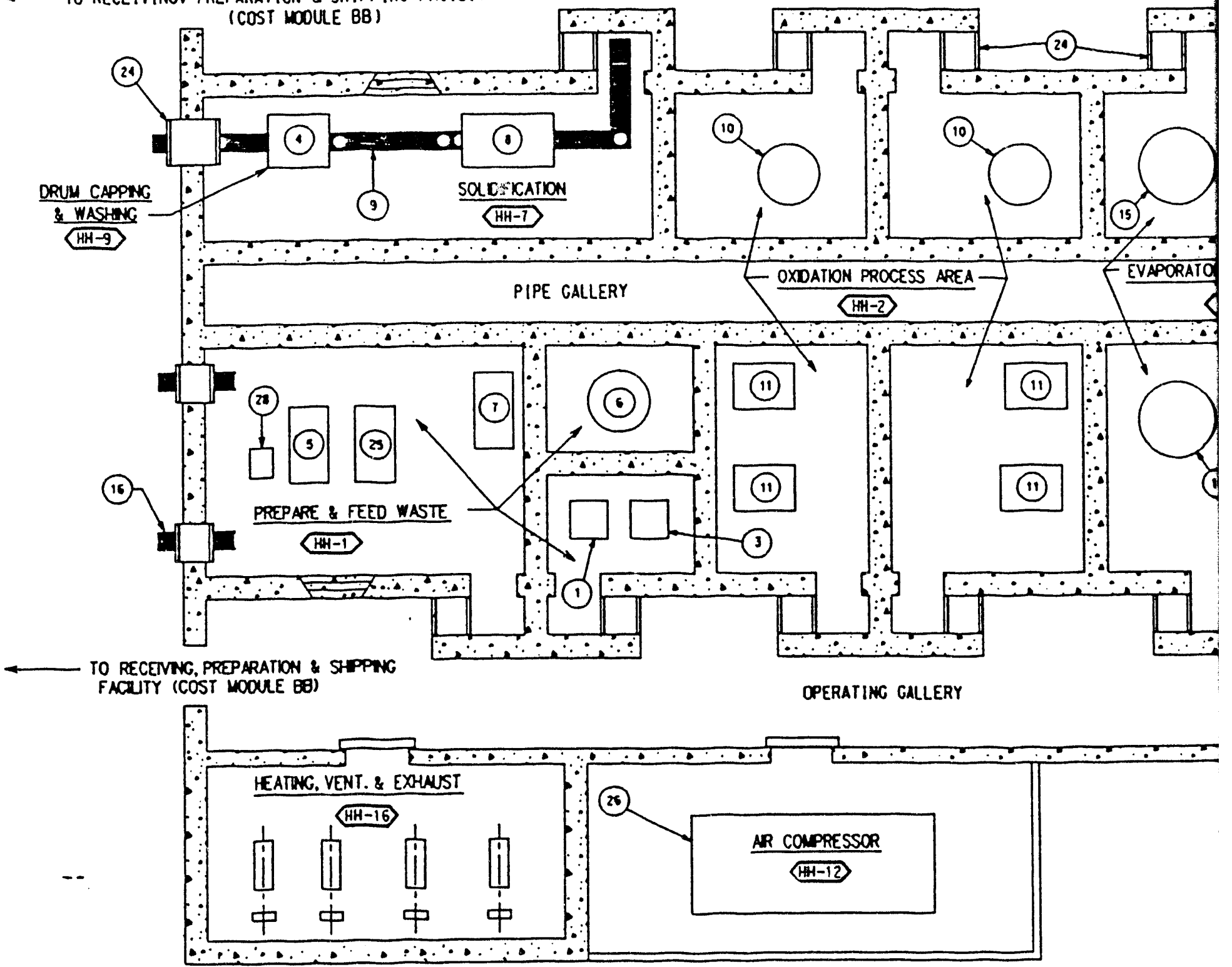

WET - AIR OXIDAT LARGE

Figure 9-1. GTCC LLW wet-air oxidation facility plan (cost module $\mathrm{HH}$ ). 
BNDER STORACE \& FEED

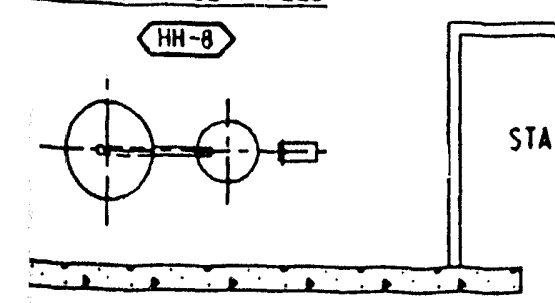

jALLERY

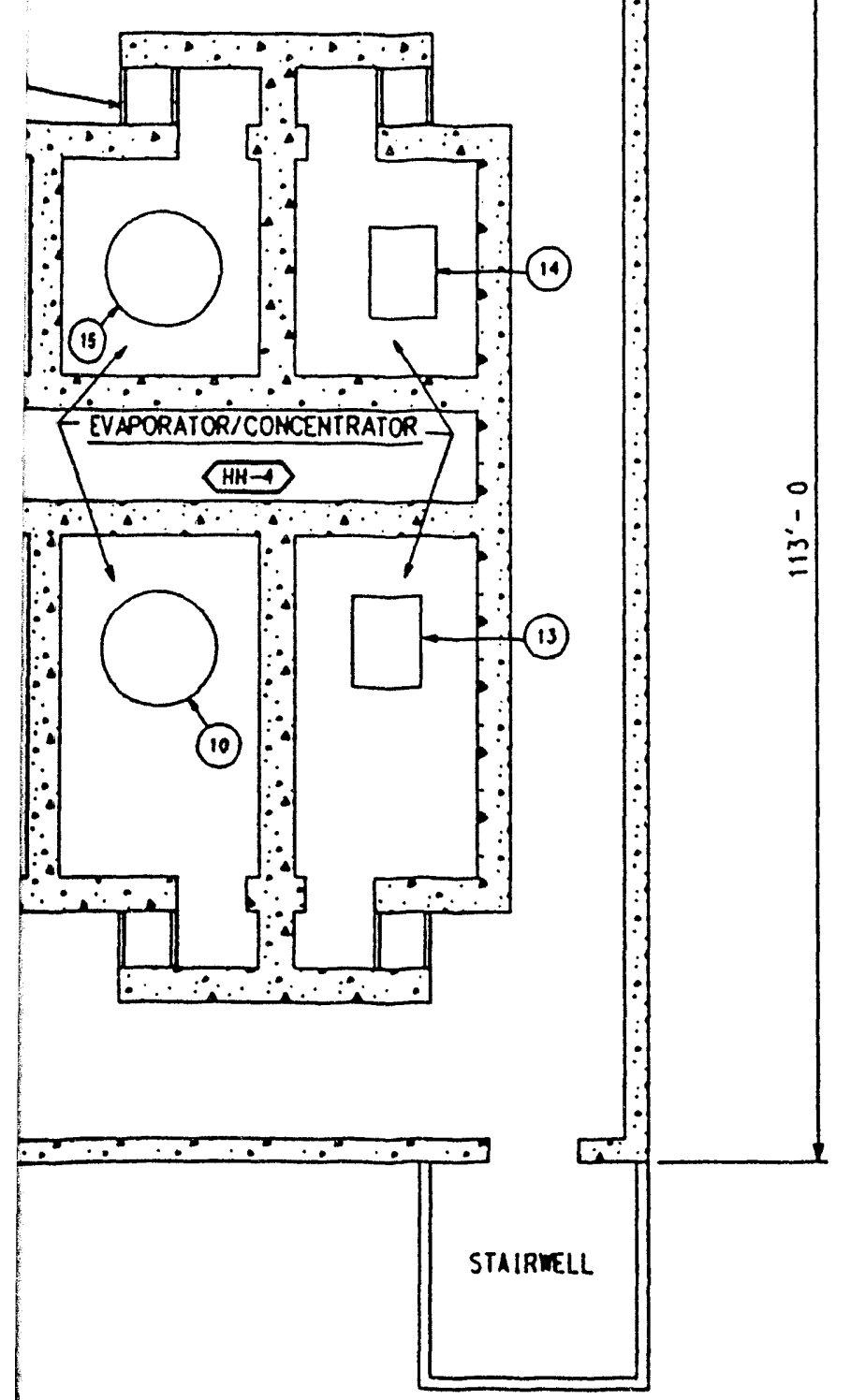

\section{MAJOR EQUIPMENT LIST}

(1) RESIN GRINOER

(2) BOILER

(3) SLuRRY Plap

(4) DRUM MASHING UNIT

(5) PRIMURY SHREDOER

(6) SLURRY FEED TAM

(7) oust calection unit

(8) saldification UNIT

(9) ROLLR CONVEYoR

(10) oxioation Reactor tanks

(11) OXIDATION REACTOR PUIPS

(12) CONOENSER

(13) racuiy SYSTEM

(14) COAPRESSOR

(15) VAPOR BOOY

(16) COMEYCR/CANISTER HANOLR

(17) Gantry robot crave

(18) FILTER dralns

(19) Blow DOW INT

(20) CHEUICN FEED TNKS/PUAPS

(21) CNISTIC FEED INAKS PTUPS

(22) INCONIMC LIOUIO STORACE TAN

(23) TREATED LIOUID SAHPLING TNA

(24) $A I R$ LOCx (ITP.)

(25) SECONDRPY SHEEDOER

(26) AIR COMPESSOR

(27) SUPL ING EOUIPLENT (TTP.)

AIR OXIDATION (COST MODULE HH) LARGE FACILITY PLAN

FIRST FLOOR

oft

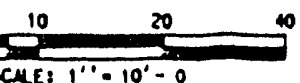

SckE: $1^{\prime \prime} \cdot 10^{\prime}-0$ 
$172^{\prime}-0$

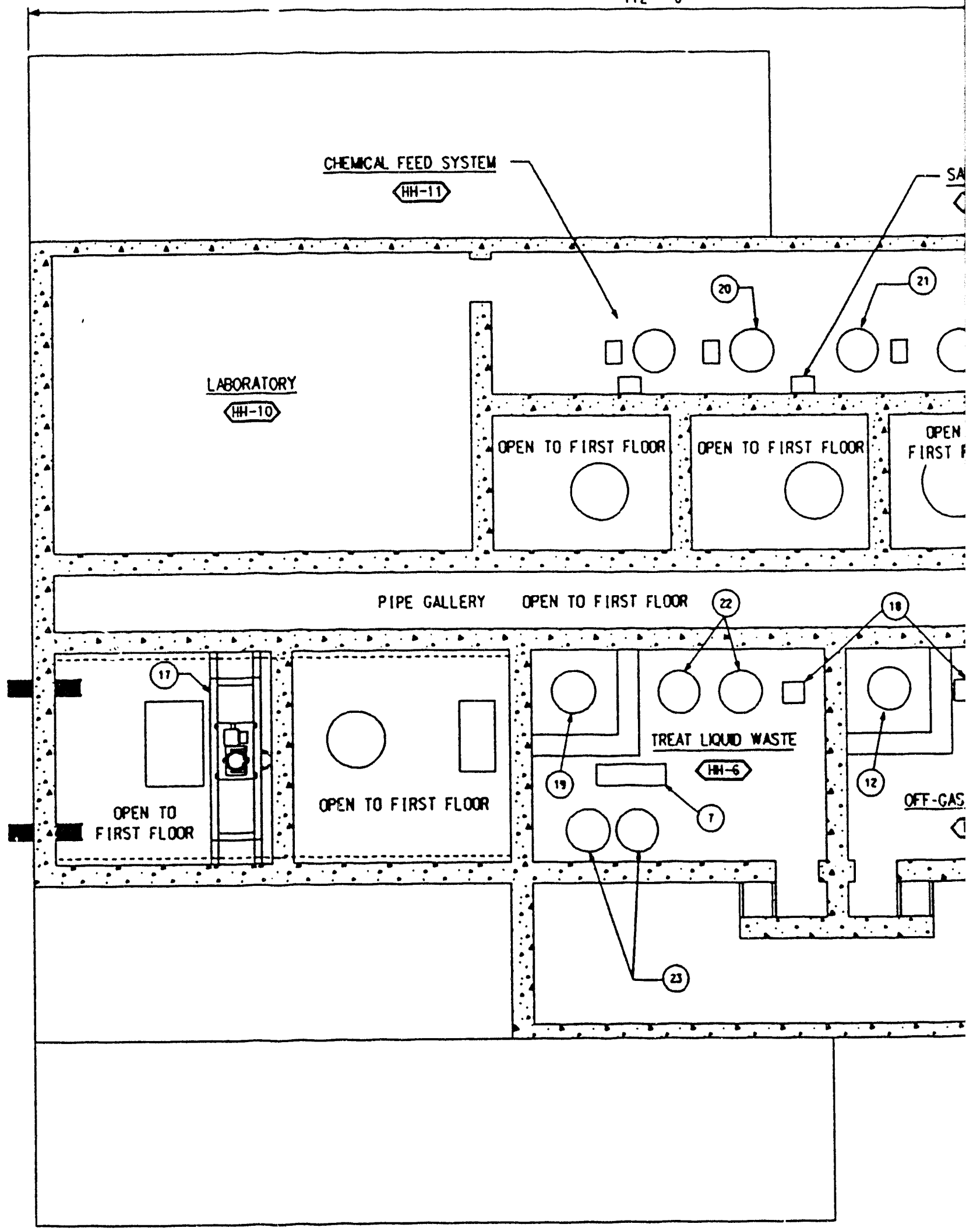

WET-AIR OXII LAR!

Figure 9-1. (continued). 


\section{MAJOR EQUIPMENT LIST}
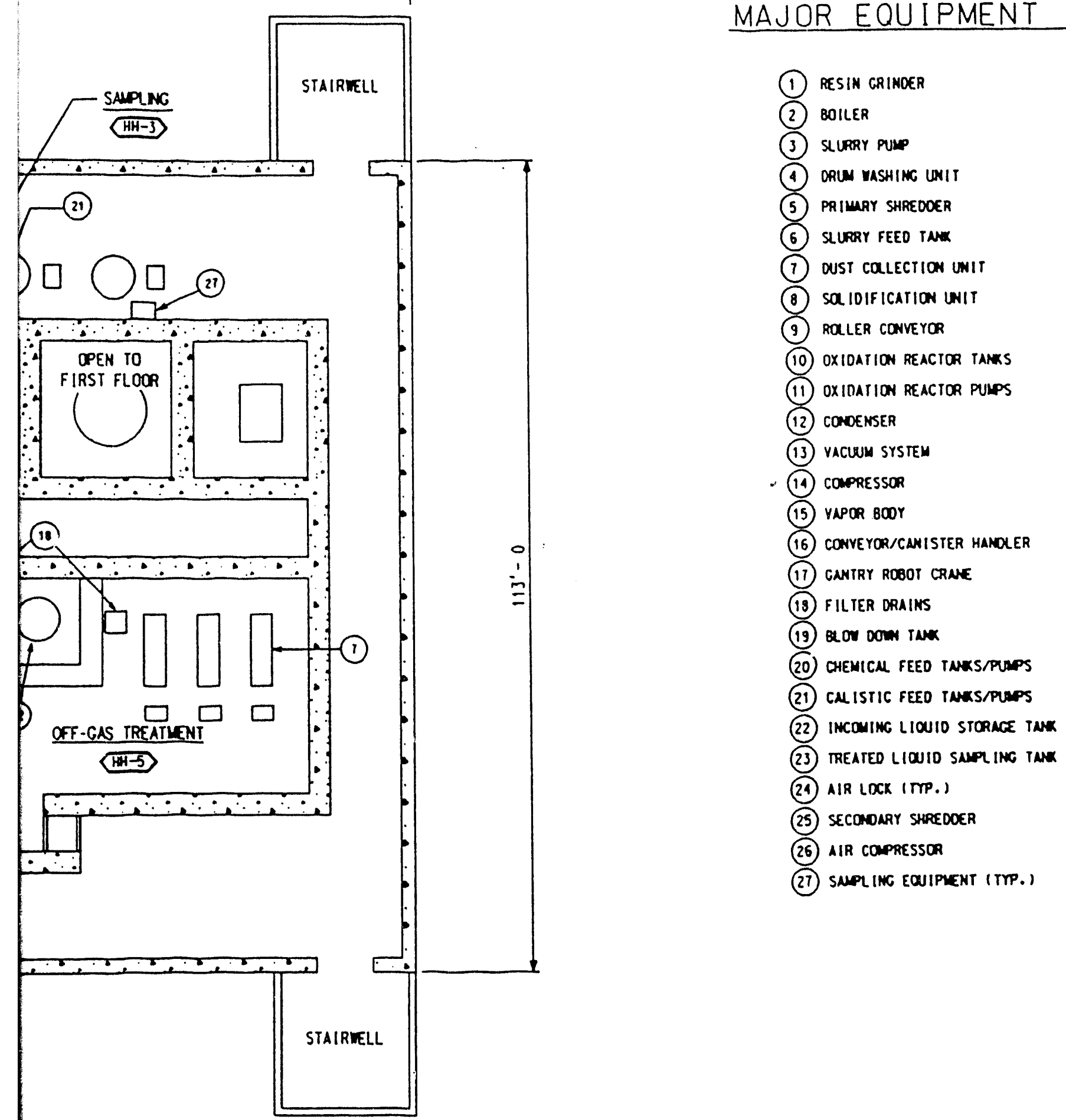

AIR OXIDATION (COST MODULE HH) LARGE FACILITY PLAN

SECOND FLOOR

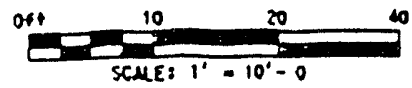




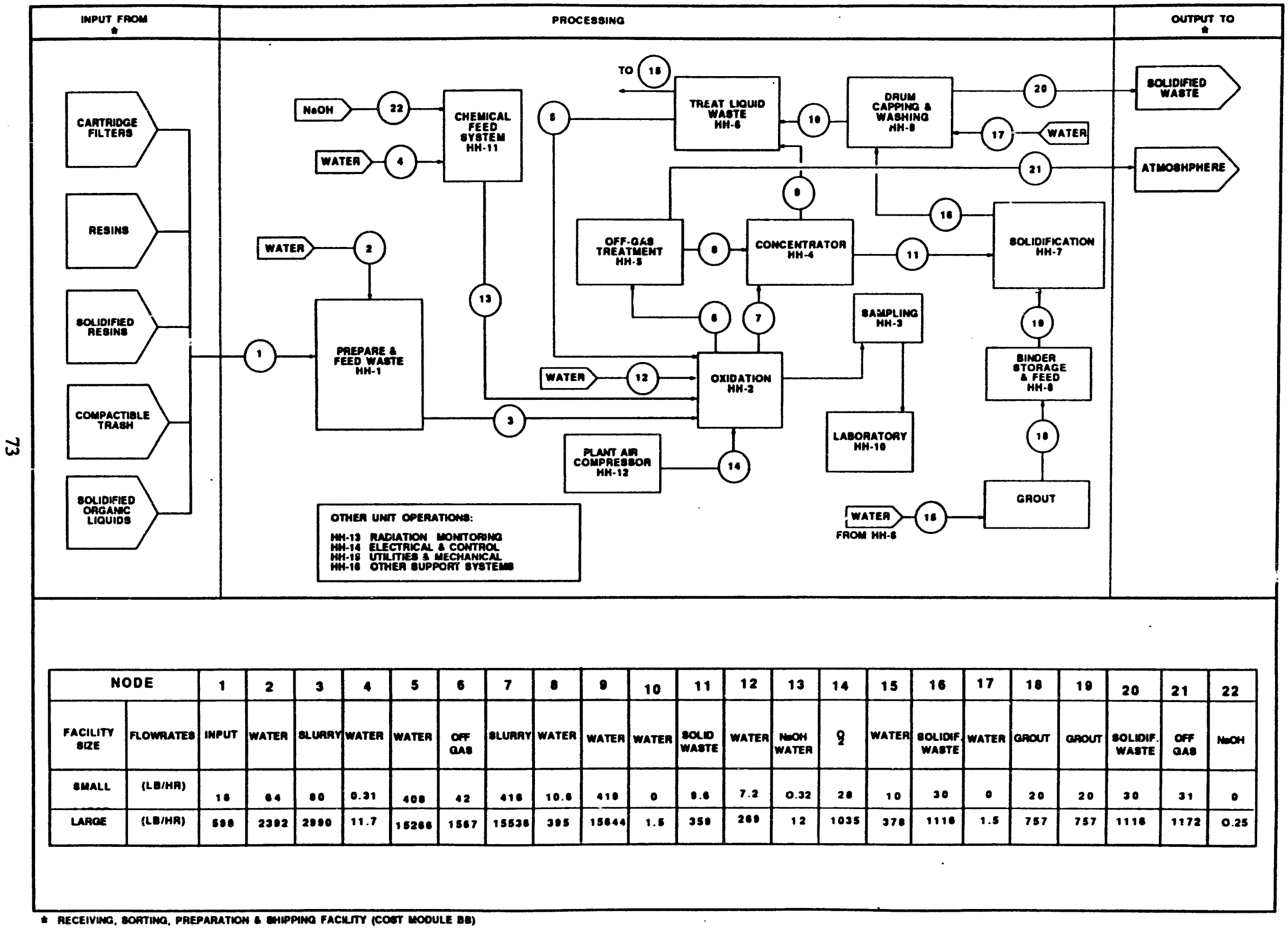

Figure 9-2. Process functional diagram for GTCC LLW wet-air oxidation facility (cost module HH). 
Following solidification, the filled drums are transferred back to the receiving, preparation, and shipping facility.

The main secondary waste from WAO process is an offgas stream. The offgas treatment unit operation for WAO consists of two steps. First, the gas is cooled to condense the water vapor, and then it passes through a HEPA filter before it is discharged. The offgas stream has very little particulate to capture, no acid gas stream to treat, or any need for secondary combustion equipment. Offgas unit operations also receive input from the concentrator which is used to process the liquid waste.

WAO support unit operations include a process control room and a laboratory. Batch processing requirements are highly dependent on the theoretical oxygen demand needed to oxidize the feed. Therefore, a dedicated laboratory is located at the facility to provide Quality Assurance/Quality Control (QA/QC) for the process. Feed sampling is integrated with the assay operation. The reactor, concentrator and solidification unit operations have remote sampling stations. Support utilities include plant steam and compressed air. Provisions are included for radiation monitoring throughout the facility.

\subsubsection{Facility Integration}

Facility input includes untreated combustible and semicombustible solids and sludge from receiving, preparation, and shipping facility.

This facility interfaces with the site communication and alarm systems including telephone, evacuation, fire, security alarm and public address systems. There are a number of consumable items that will be purchased from outside vendors for O\&M purposes which include: drums, solidification agent, personal protective equipment, laboratory supplies, chemicals, and HEPA filters. Facility output includes packaged solidified waste to receiving, preparation, and shipping facility (cost module $\mathrm{BB}$ ).

\subsection{Cost Bases, Assumptions and Assessments}

General cost bases and assumptions are given in Appendix A. Facility-specific items are discussed below:

- The main equipment for this facility is wet oxidation system. Quotation for this system is obtained from the Zimpro Passavant Company and Toyo Engineering Corporation of Japan.

- $\quad$ Estimated operating staff is shown below in Table 9-1.

- Small, medium and large facility capacities and unit costs are shown in Table 9-2.

\subsection{Cost Summaries}

A cost summary for the wet-air oxidation facility is shown in Table 9-3. A histogram of cost vs. capacity is given in Figure 9-3. 
Table 9-1. Estimated operating staff for GTCC LLW wet-air oxidation facility (cost module HH).

$\begin{array}{lll}\text { Unit } & \text { Description } & \text { Small (FTE) }\end{array}$

\begin{tabular}{llll} 
HH-1 & Prepare and Feed Waste & 0.5 & 1 \\
HH-2 & Oxidation & 1.5 & 5 \\
HH-3 & Sampling & 0.0 & 1 \\
HH-4 & Concentrator & 0.0 & 1 \\
HH-5 & Offgas Treatment & 0.0 & 1 \\
HH-6 & Treat Liquid Waste & 0.0 & 1 \\
HH-7 & Solidification & 0.5 & 1 \\
HH-8 & Binder Storage and Feed & 0.5 & 1 \\
HH-9 & Drum Capping and Washing & 0.5 & 1 \\
HH-10 & Laboratory & 1.5 & 6 \\
HH-11 & Chemical Feed System & 0.5 & 2 \\
HH-12 & Plant Air Compressor & 0.0 & 1 \\
HH-13 & Radiation Monitoring & 0.5 & 2 \\
HH-14 & Electrical \& Control & 0.5 & 1 \\
HH-15 & Utilities \& Mechanical & 0.5 & 1 \\
HH-16 & Heating, Ventilation \& Exhaust & 0.0 & 0 \\
HH-17 & Other Support Systems & 0.5 & 3 \\
& & & 29 \\
& Total & 7.5 & \\
\hline
\end{tabular}

Table 9-2. Capacities and unit costs for GTCC LLW wet-air oxidation facility (cost module HH).

\begin{tabular}{|c|l|r|r|r|r|r|}
\hline $\begin{array}{c}\text { Module } \\
\text { Code }\end{array}$ & \multicolumn{1}{|c|}{$\begin{array}{c}\text { Cost Module } \\
\text { Description }\end{array}$} & Facility & $\begin{array}{c}\text { Life Cycle } \\
\text { Cost } \\
(\$ \times 1000)\end{array}$ & $\begin{array}{c}\text { Total } \\
\text { Capacity } \\
(\mathrm{lbs} X 1000)\end{array}$ & $\begin{array}{c}\text { Capacity } \\
(\mathrm{lbs} / \mathrm{hr})\end{array}$ & $\begin{array}{r}\text { Unit Cost } \\
(\$ / 1 \mathrm{~b})\end{array}$ \\
\hline $\mathrm{HH}$ & Wet Air Oxidation & Small & 288,238 & 1290 & 16 & $\$ 223$ \\
\hline $\mathrm{HH}$ & Wet Air Oxidation & Large & 808,275 & 48223 & 598 & $\$ 17$ \\
\hline
\end{tabular}


Table 9-3. PLCC estimate summary for GTCC LLW wet-air oxidation facil:‘y (cost module HH).

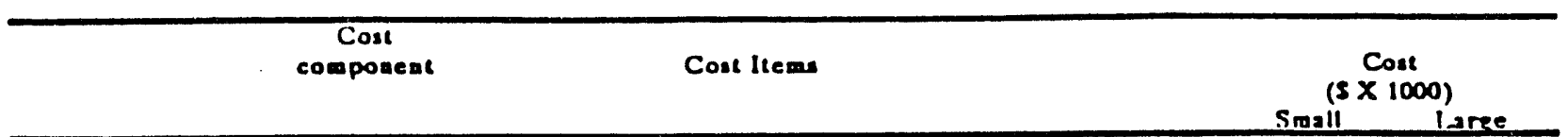

1.0

Studies and bench scale test costs

1.1 Manpower costs during research

12 Equipmeat coss

is insullacion costs

1.t Project managemeat before title! ( $10 \%$ of 1.1 through 1.3)

I.S Contingency

( 25 ? of 1.1 through 1.4 ) Smal

laree

Sublolal 1.0

\begin{tabular}{|c|c|}
\hline si,soo & S1.500 \\
\hline$\$ 100$ & $\$ 100$ \\
\hline$\$ 200$ & $=\infty$ \\
\hline 5180 & 5180 \\
\hline $5+95$ & SH9S \\
\hline 52.475 & $52 .+75$ \\
\hline sisoo & Si.S00 \\
\hline$\$ 387$ & 5387 \\
\hline 590 & 590 \\
\hline$\$ 129$ & 5129 \\
\hline 5500 & $s s 00$ \\
\hline$s s 00$ & $\$ 500$ \\
\hline 590 & 5290 \\
\hline 51290 & 51290 \\
\hline $\operatorname{sen} 1$ & sent \\
\hline 5129 & $\$ 129$ \\
\hline$\$ 937$ & $\$ 937$ \\
\hline S4.683 & 54.683 \\
\hline
\end{tabular}

3.0

Demonstration costs

2.1 Manpower coss during demonstration

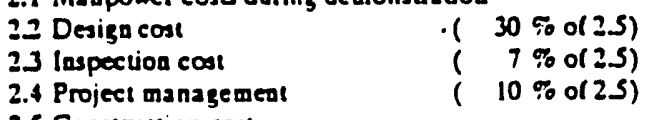

590

2.5 Construction cost

2.5.1 Buildiag surveture costs

252 Equipment costs

2.5 .3 Lodireet ( $29 \%$ of 2.5 .1 \& 2.5.2)

Subtotal or 25

2.6 Consuruction management costs

2.7 Management Resene

2.8 Contingency

( $17 \%$ of 2.5 )

( $10 \%$ of 2.5 )

Subtotal 2.0

Production tacility construction costs

3.1 Desiga cost

32 Inspection cost

33 Project managemeat

( $18 \% \circ$ o( 3.4)

( $7 \%$ of 3.4$)$

( $10 \%$ of 3.4)

11356

54.377

50.254

528.923

3.t Construction cost

3.4.1 Building structure costs

3.42 Equipmeat costs

3.43 lodirec

( $29 \%$ or $3.4 .1 \& 3.42)$

524.643

523.834

S14.058

Subtotal of 3.4

35 Construction manageneat

( $17 \%$ of 3.4 )

( $10 \%$ of 3.4$)$

3.6 Managemeat Rexerve

$(10 \%$ o( 3.4$)$
$(25 \%$ ol 3.1 (brough 3.5)

3.7 Cooliagescy

Sublotal 3.0

562.535

510.693

56.254

523.779

5125.148

$5112+8$

$\$ 16.069$

Operations Budget Funded Activities (See Sect 7)

t.1 Conceptual desigo

$(1.590$ o( 3.0$)$

+.2 Salety assurance

( $19 \%$ of 3.0 )

4.3 NEPA permitting (5 6 Mill for ELS. S1 Mill for EA)

4.4 Preparation for operations

( $100 \%$ or 5.0$)$

+3 Project Management

( $10 \%$ of 4.1 through 4.4)

Sublotal 4.0

538.177

586.385

$\$ 36.123$

$\$ 160.685$

27.477

$\$ 16.069$

561.101

5021.572

Total laitial Cose (1.02.0.3.0\& 4.0)

51.377

S1.2S1

56.000

56.351

S1.548

517.027

54.824

53216

56.000

$\$ 21.176$

50.527

538.738

$\$ 149.333$

$\$ 567.168$

5.0 Operatiog and mainuinence cosss (Loading / Ualoading Period)

S.1 Anaual operating cosis

SI Anqual utility coscs

S3 Anqual material cosis

S.4 Aanual mainuinence cosus

S.S Coacingency

( 2590 of 5.1 through 5.4)

S.6 Subiotal 5.0

5.7 Total 20 year O \& M cost (20 times Subtotal 5.0 )

\$1.050 $\$ 4.060$

$\$ 19 \quad \$ 316$

$586 \quad 5621$

$\$ 3.896 \quad 511.944$

- $\$ 1.270 \quad 51235$

$\$ 6.351 \quad 51.176$

$\$ 127,020 \quad 5+23,520$

S423.520

S11.885

517237

6.0 Decontamination \& Decommissioning

5288238

$\operatorname{ssos} 275$ 


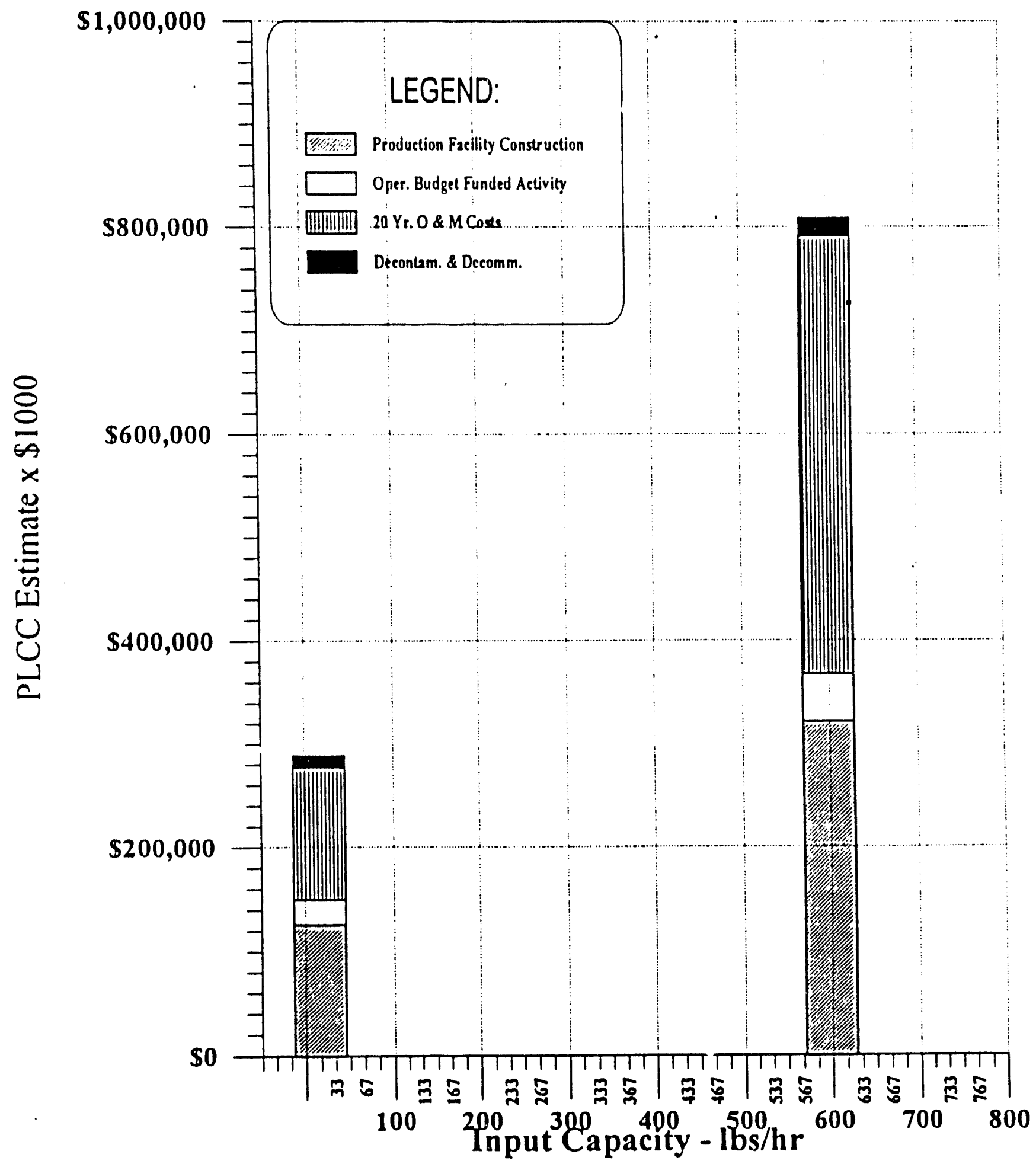

Figure 9-3. Cost versus capacity histogram for GTCC LLW wet-air oxidation facility (cost modulc $\mathrm{HH})$. 


\section{METAL SIZING/DECONTAMINATION FACILITY (COST MODULE II)}

\subsection{Basic Information}

The GTCC LLW metal sizing and decontamination facility shown in Figure 10-1 comprises fourteen unit operations that are used to pretreat, reduce the size, decontaminate and package the incoming contaminated bulk metals, loose metals, and empty metal containers. The facility decontaminates GTCC LLW metals to radiation levels acceptable for recycling or disposal in shallow land disposal facilities. The facility must be either used in conjunction with the receiving, preparation, and shipping facility, or constructed next to existing facilities where similar functions are already in place. Unit operations that accomplish the general functions are shown in Figure 10-2.

\subsection{Technical Basis and Assumptions}

\subsubsection{Functional and Operational Description}

At the facility the drums are transferred to a pretreatment unit operation which receives the bulk metals and places them in a shielded staging area. Using remote handling techniques the bulk metal is cleaned using a high-pressure rinse to remove debris, soil and other loose contamination. The cleaned waste is then transferred to either a size reduction unit operation or to a metal decontamination unit operation.

At the size reduction unit operation, the material is cut to the desired size. The size reduction unit operation also treats any air containing fugitive dust from the shredding and the related operations. The size-reduced metals are conveyed via a transfer device to the inspection unit operation. The inspection unit operation is used to identify whether materials have entrained contamination and/or surface contamination. Following the inspection unit operation, the contaminated metals are directed to the appropriate decontamination process in the decontamination unit operation.

The decontamination unit operations employs chemical and physical decontamination techniques to remove surface and entrained contamination. For surface contamination, abrasive blasting, grinding, and other mechanical techniques are used. For entrained contamination, electro-polishing and acid etching are used.

After decontamination, the material is transferred to the assay/inspection unit operation. This unit operation assays decontaminated metals to ensure all land disposal restriction (LDR) controlled components are removed. Metals requiring additional decontamination are returned to the decontamination unit. The assayed materials are placed in 55-gal drums and sent to the compaction and packaging unit operation.

At the compaction and packaging unit operation, a lift device places the filled drums onto press conveyors. The operator selects a drum from one of the conveyors and feeds it to the press through an airlock, located in the press negative pressure environmental chamber. A device pierces the drum to release any gases potentially trapped in the drum into the confined chamber. A high-pressure compactor (supercompactor) compresses the drum and transfers it to a staging conveyor (or turntable). A lift device picks up the compressed drum and places it into one of several overpacks 


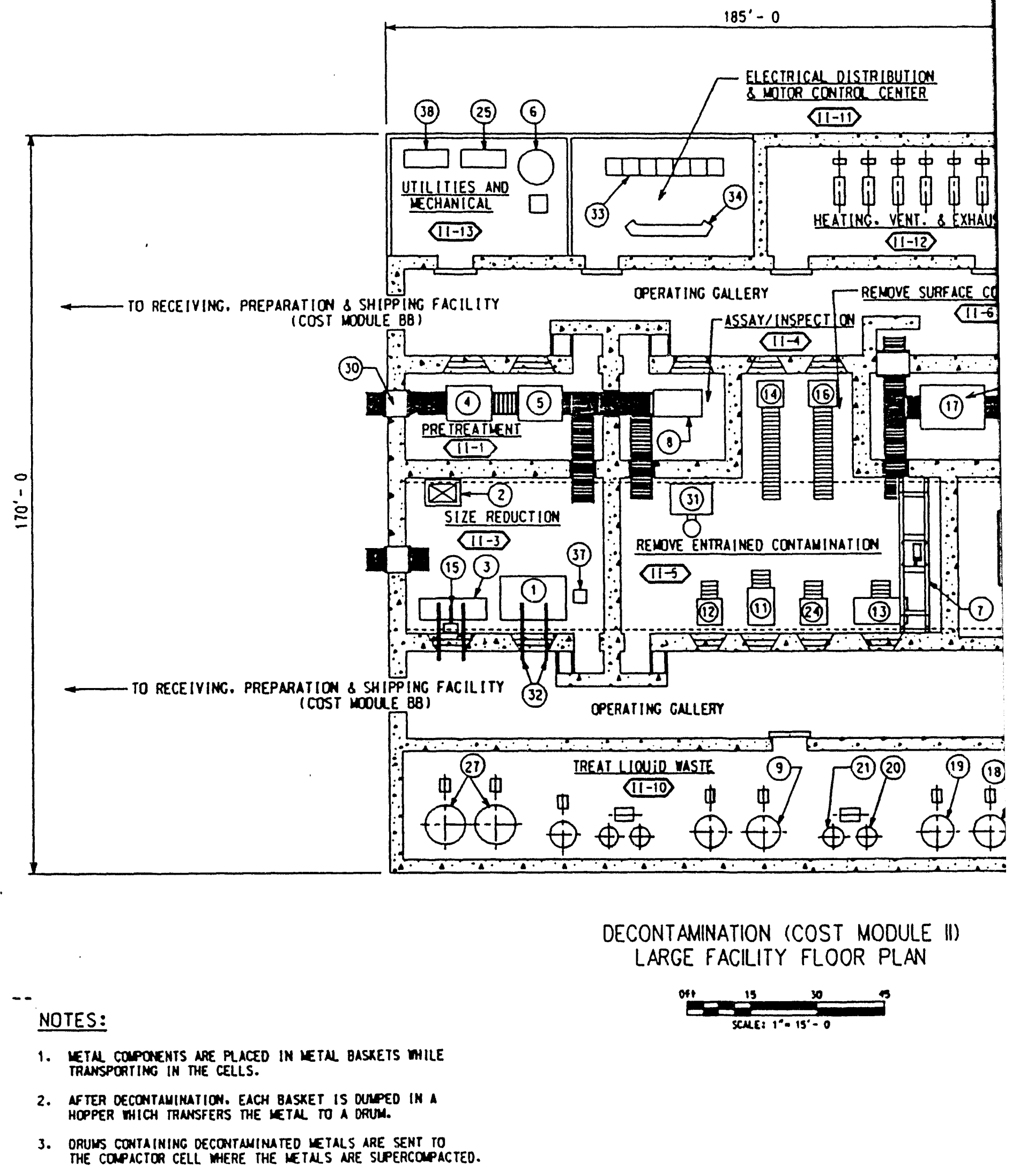

Figure 10-1. GTCC LLW metal sizing/decontamination facility plan (cost module II). 


\section{MAJOR EQUIPMENT LIST}

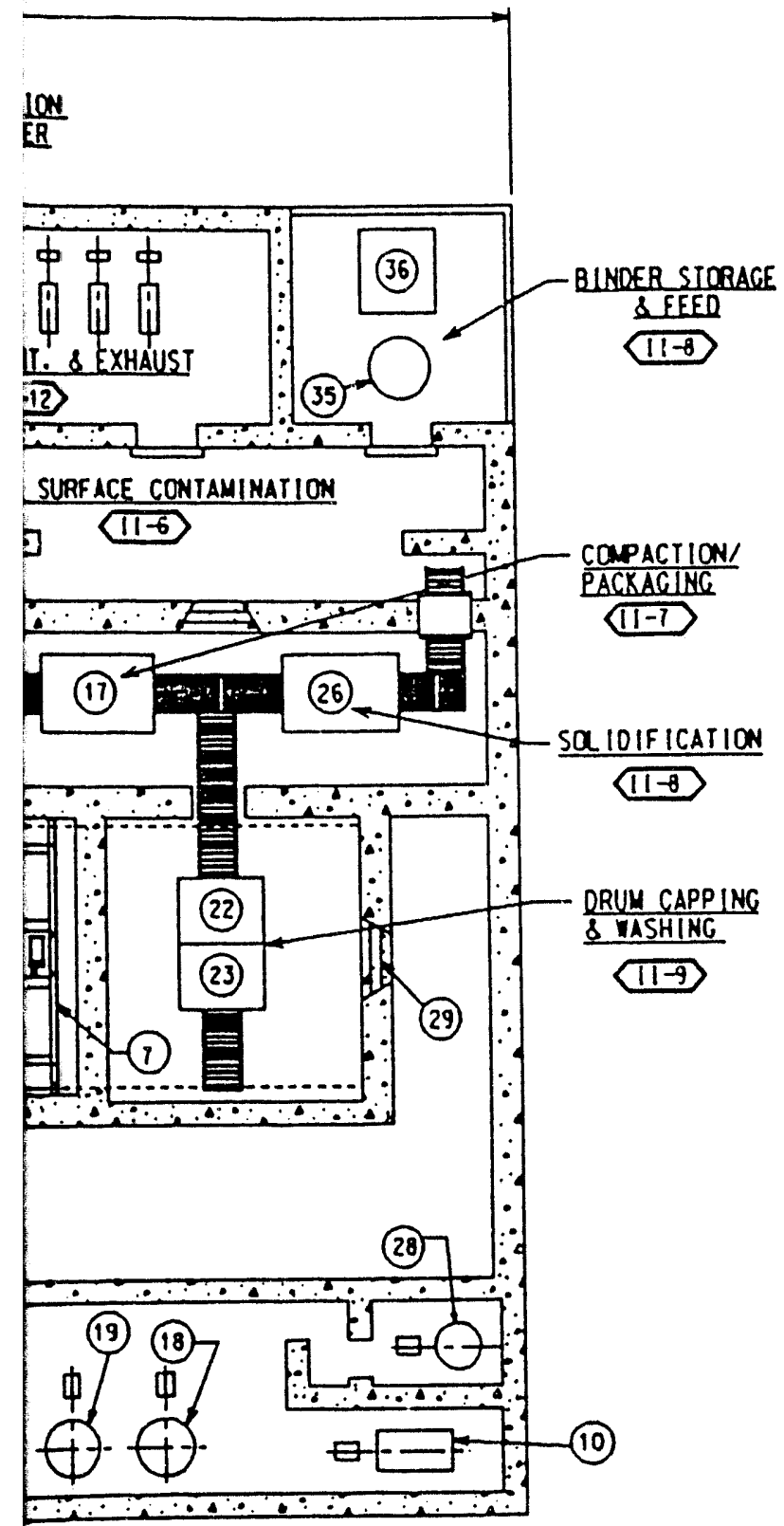
(1) Cutting station
(2) OUST COLECTION HOOO
(3) DISSASSEMGLY STATION
(4) RINSE STATION
(5) DRYING station
(6) SERVICE Mater TMa
(7) 5 TON OVERHENO CRME
(8) assar unit
(9) Ion exchance Vessel

(10) FILTRATION UNIT

(11) BULX MTERIN CHEUICN ETCHINC BOOTH

(12) BULK MTERINL BLASTING BOOTH

(13) ELECTRO POL ISH BOOTH

(14) blast cleaning booth

(15) HYORAULIC MANIPUATOR BOOTH

(16) RINSE BOOTH

(17) COMPACIIOM/PACKACING SYSTEM

(18) vedia cleaming tank

(19) LeDIA STORAGE TMMK

(20) CHEMICAL ETCHIMG SOUTION HODOIMG TAMK

(21) CHEMICN ETCHINC SOUtion RECrCLE tAN

(22) DRLM MASHING

(23) DPLW CAPPING

(24) BUK MTERINL RINSE BOOTH

(25) INSTRUENT AIR COPRESSOR

(26) SOL IDIFICATION UNIT

27) LIOUID MASTE TREATENT TNKK

(20) SLUOCE TMKK

(29) SHIELDING WINOON (TTP.)

(30) AIR LOCX (ITP.)

(31) BASXET DUAP/DRUM FILL

(32) MSTER SLAVE MANIPULATOR (TTP.)

N

(33) WTTO CONTRO CEMTER

(34) MIN CONTRO PANEL

(35) BINOER SILO

(36) BINOER FEED

(37) BASXET

(30) SERVICE AIR COAPESSOR 


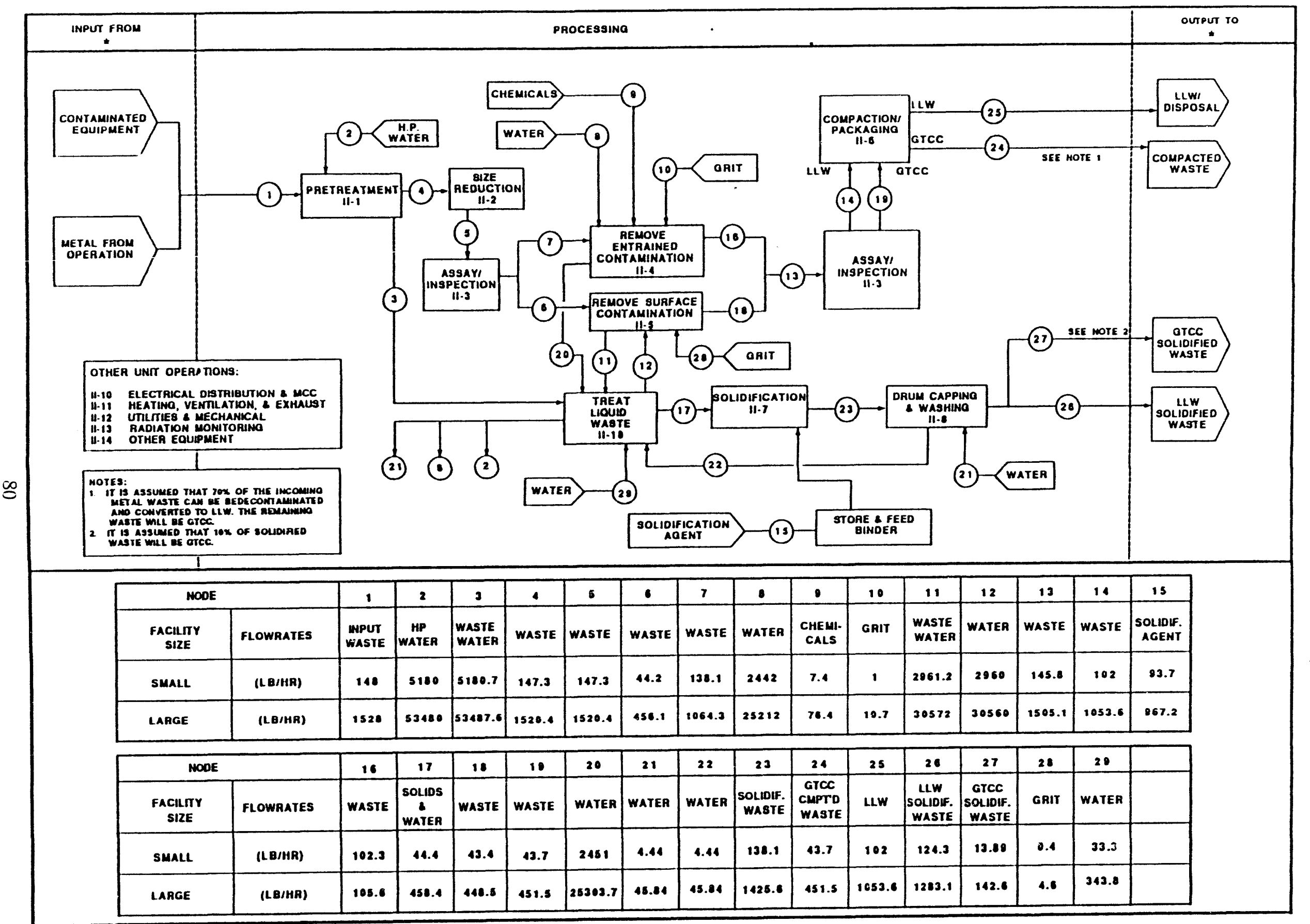

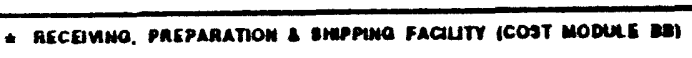

Figure 10-2. Process functional diagram for GTCC LLW metal sizing/decontamination facility (cost module II). 
located on an adjacent conveyor. After cach overpack is filled, the operator feeds it first to a grouting station and then to a seaming machine where a cap is placed on the overpack and seamed. The operator moves the sealed overpack to a drum washing unit where high-pressure water spray jets remove any loose contamination on the outside surface of the overpack. Any liquid generated during the press operation is directed to a sump and sent to the liquid waste treatment unit operation.

Any liquid produced from the decontamination unit operation is collected and pumped to the liquid waste treatment unit operation which reduces the volume and detoxifies the waste to meet output criteria. A combination of evaporation, precipitation, filtration, and centrifuge treatment methods are used. The treated clean liquid is received in the decontamination unit operation, and the sludge material is solidified and packaged in the solidification unit operation.

In the solidification unit operation, the waste is mixed with a binder (such as Portland cement) and packaged into disposal containers. The unit operation has remotely operated devices needed for accepting the incoming waste, mixing it with the binder and packaging the mixture in disposal containers.

After proper mixing, the drum is remotely moved to a capping and washing unit operation. After capping, loose contamination is removed from the container's outer surface by high pressure spray water jets. This unit operation also provides for solidified matrix sample collection. The containerized waste is transported to the receiving, inspection, and shipping facility.

The anticipated density of the compacted waste is about $200 \mathrm{lb} / \mathrm{ft}^{3}$. The solidified waste density is $112 \mathrm{lb} / \mathrm{ft}^{3}$.

\subsubsection{Facility Integration}

The facility receives metal waste from the receiving, preparation, and shipping facility (cost module BB). The four major output waste types from this facility include compacted GTCC LLW metals, LLW metals, recyclable/reusable metals, and solidified LLW waste in 55-gal drums. The output of this facility is sent to the receiving, preparation, and shipping facility. Any offgas generated is treated and discharged to the atmosphere. O\&M consumables including empty containers, solidification binder, and personal protective equipment are purchased.

\subsection{Cost Bases, Assumptions and Assessments}

General cost bases and assumptions are given in Appendix A. Facility-specific items are discussed below:

- Estimated operating staff is shown below in Table 10-1.

- Small and large facility capacities and unit costs are shown in Table 10-2.

\subsection{Cost Summaries}

A cost summary for the GTCC LLW metal sizing/decontamination facility is shown in Table 10-3. A histogram of cost vs. capacity is given in Figure 10-3. 
Table 10-1. Estimated operating staff. for GTCC LLW metal sizing/decontamination facility (cost module II).

\begin{tabular}{llrr}
\hline Unit & Description & $\begin{array}{c}\text { Small } \\
\text { (FTE) }\end{array}$ & $\begin{array}{r}\text { Large } \\
\text { (FTE) }\end{array}$ \\
\hline II-1 & Pretreatment & 2.00 & 10 \\
II-2 & Size Reduction & 1.00 & 10 \\
II-3 & Assay/Inspection & 0.00 & 4 \\
II-4 & Remove Entrained Contamination & 2.00 & 5 \\
II-5 & Remove Surface Contamination & 2.00 & 5 \\
II-6 & Compaction/Packaging & 0.50 & 4 \\
II-7 & Solidification & 0.50 & 5 \\
II-8 & Drum Capping \& Washing & 0.50 & 2 \\
II-9 & Treat Liquid Waste & 0.50 & 2 \\
II-10 & Electrical \& MCC Distribution & 0.50 & 2 \\
II-11 & Heating, Ventilation \& Exhaust & 0.50 & 2 \\
II-12 & Utilities \& Mechanical & 0.00 & 2 \\
II-13 & Radiation Monitoring & 0.00 & 0 \\
II-14 & Other Equipment & 1.00 & 1 \\
& & & \\
& Total & 11 & 55 \\
& & & \\
\hline
\end{tabular}

Table 10-2. Capacities and unit costs for metal sizing/decontamination facility (cost module II).

\begin{tabular}{|c|l|r|r|r|r|r|}
\hline $\begin{array}{c}\text { Module } \\
\text { Code }\end{array}$ & \multicolumn{1}{|c|}{$\begin{array}{c}\text { Cost Module } \\
\text { Description }\end{array}$} & Facility & $\begin{array}{c}\text { Life Cycle } \\
\text { Cost } \\
(\$ \times 1000)\end{array}$ & $\begin{array}{c}\text { Total } \\
\text { Capacity } \\
(\mathrm{lbs} \text { X1000) }\end{array}$ & $\begin{array}{c}\text { Capacity } \\
(\mathrm{lbs} / \mathrm{hr})\end{array}$ & $\begin{array}{c}\text { Unit Cost } \\
(\mathbf{S} / \mathrm{b})\end{array}$ \\
\hline II & Metal Sizing/ Decon. & Small & 232,069 & 11935 & 148 & $\$ 1$ \\
\hline II & Metal Sizing/ Decon. & Large & 522,169 & 123218 & 1,528 & \\
\hline
\end{tabular}


Table 10-3. PLCC estimate summary for metal sizing/decontamination facility (cost module II).

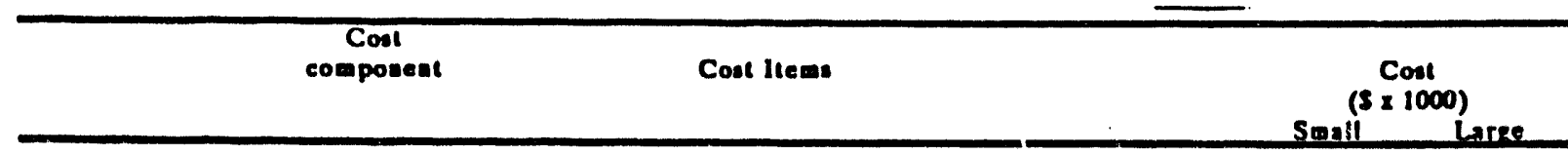

Studies and bencb scale lest costs

1.1 Manpower costs duriog research

12 Equipment costs

1.3 Installation costs

1.4 Project management belore title I ( $10 \%$ of 1.1 through 1.3)

1.5 Contingency

( $25 \%$ of 1.1 tbrough 1.4 )

Subtotal 1.0

Demonstration costs

2.1 Maspower costs during demonstration

$\begin{array}{ll}2.2 \text { Desiga coat } & (30 \% \text { or } 2.5) \\ 2.3 \text { lospection cost } & (7 \% \text { of } 2.5) \\ 2.4 \text { Project managemeat } & (10 \% \text { of } 2.5)\end{array}$

2.4 Project wanageweat

$(10 \%$ of 25$)$

2.5 Coastruction cost

$\begin{array}{ll}2.5 .1 & \text { Building structure conts } \\ 2.52 & \text { Equipment conts }\end{array}$

Subtotal of 2.5

2.6 Construction managemeal costs

2.7 Management Reserve

( $29 \%$ of 2.5 .1 2.5.2)

2.8 Contingency

Subtotal 2.0

( $17 \%$ of 2.5 )

( $10 \%$ of 2.5$)$

( $25 \%$ of 2.1 through 2.7 )

Production facility construction costs

3.0

3.1 Desiga cost

32 Iospection cost

3.3 Project maagemeat

$(18 \%$ of 3.4$)$

3.4 Construction cost

3.4.1 Buildiag structure conts

3.42 Equipmeat conts

3.4 .3 Indirect

$(29 \%$ of $3.4 .1 \times 3.42)$

Subtotal of 3.4

3.5 Construction manazemeot

3.6 Management Reserve

( $17 \%$ of 3.4$)$

( $10 \%$ of 3.4 )

( $25 \%$ of 3.1 through 3.5 )

Subtois

( $25 \%$ or 3.1 through 3s)

4.0 Operations Budget Funded Activities (See SecL 7 )

4.1 Conceptual desiza $\quad(1.5 \%$ of 3.0$)$

4.2 Safety assurace (1\% of 3.0 )

4.3 NEPA permitting ( 6 Mill for EIS, $\$ 1$ Mill for EA)

4.4 Preparation for operations ( $100 \%$ of 5.0$)$

45 Project Maaagemeal $\quad(10 \%$ ol 4.1 through 4.4)

Subtotal 4.0

Toral Initial Cost $(1.02 .0,3.0 \& 4.0)$

$\begin{array}{ll}S 0 & S O \\ S 0 & S 0 \\ S 0 & S O \\ S 0 & S 0 \\ S 0 & S 0 \\ S 0 & S O\end{array}$

Operntiag and maintaineuce conts (Loading / Unlosdiog Period)

S.1 Annual operating costs

5.2 Anoual utility conts

5.3 Angual material costs

S.4 Anoual maintaineace conts

5.5 Coatiogency

S.6 Subtotal 5.0

( $25 \%$ of 5.1 through 5.4 )

5.7 Toul 20 year $O$ \& $M$ coul (20 times Subtotal 5.0 )

6.0 Decontamiastion \& Decommissioniog

99.192

$\mathbf{5 3 . 5 7 5}$

5.107

514,438

$\mathbf{5}, 615$

$\mathbf{2 3 , 1 1 8}$

$\$ 16,470$

$\$ 11,481$

$\$ 51,069$

$\$ 8.733$

5,107

$\$ 19.419$

$\$ 102,202$

$\mathbf{8 8 , 0 2 1}$

$\mathbf{5 3 5 . 1 3 3}$

27.046

$\$ 18.032$

580211

$\$ 13.716$

$\$ 8.021$

530,500

5160.522

51,533

$\$ 1,022$

$\$ 6,000$

55238

51.379

S15, 172

$\mathbf{2 . 4 0 8}$

$\$ 1,605$

$\$ 6,000$

$\$ 15.918$

52593

52524

$\$ 117374$

5189,046

$\mathbf{5 1 , 6 1 0 \quad \mathbf { 5 7 , 9 8 0 }}$

$553 \quad 521$

$5105 \quad 5568$

$\mathbf{8 . 4 2 2} \mathbf{5 3 . 9 6 5}$

$\$ 1.048 \quad \mathbf{S 3 . 1 8 4}$

$\$ 5238 \quad 515,918$

$\$ 104,760 \quad \mathbf{3 1 8 , 3 6 0}$

$\$ 9,935$

$\$ 14,763$

ROM Life cycle costs (20 years operatioa)

$\mathbf{2 3 2 , 0 6 9}$

352.169 
(II गाnpow jsos)

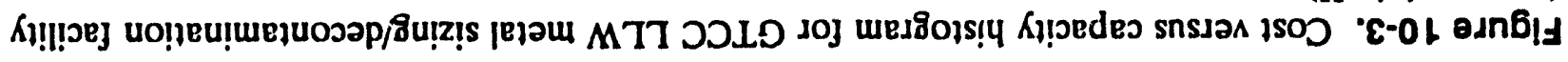

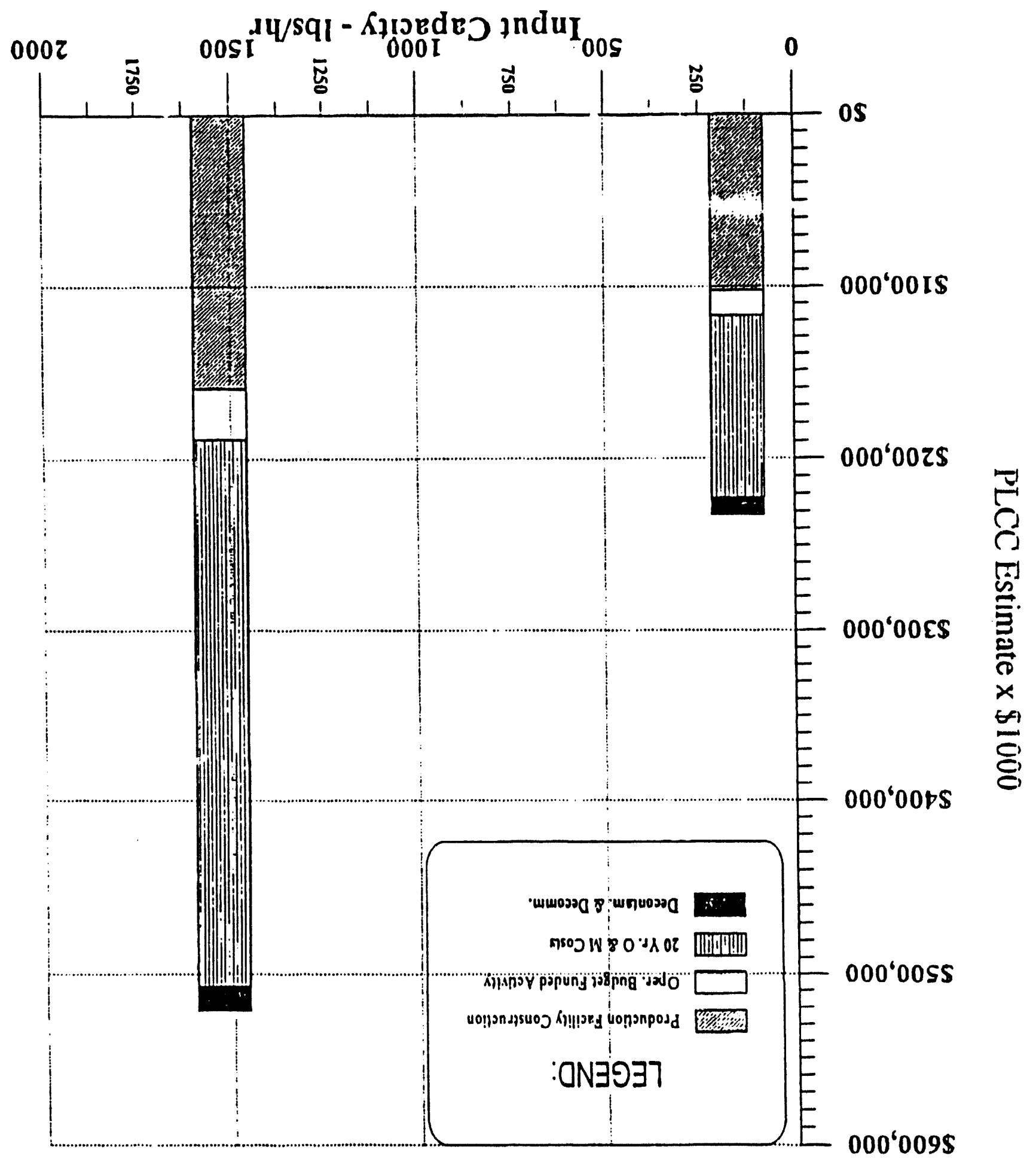




\section{ENCLOSED VAULT STORAGE FACILITY (COST MODULE Z)}

\subsection{Basic Information}

The enclosed vault storage facility, shown in Figures $11-1$ and 11-2, is used in conjunction with GTCC LLW treatment facilitics (cost module CC, EE, FF, GG, HH, and II), and the receiving, preparation, and shipping facility (cost module BB). In addition, the facility can accept packaged waste lrom waste generators or other sources. The facility receives GTCC LLW drums from the treatment facility and holds them in shielded vaults for long-term storage. The facility is suitable for storage of waste having high gamma radiation and requiring remote handling. The storage concept used for GTCC LLW vault storage is the same as that used for the SNF hardware and scrap metal storage facility. Unit operations that accomplish these general functions are shown in Figure 11-3 (Feizollahi and Shropshire 1993a).

\subsection{Technical Basis and Assumptions}

\subsubsection{Functional and Operational Description}

Treated GTCC LLW waste in metal drums are brought from the receiving, preparation, and shipping facility in a shield cask mounted on a transportation vehicle. At the vault storage facility, an unload and stage unit operation receives and inspects the vehicle and shield cask, and removes the cask cover. Using remote handling techniques, the unit operation removes the drums from the shield cask and places them in a shielded assay inspection cubicle. When a drum removal operation is completed, the empty cask and trailer is inspected, the cask lid is attached, and the trailer is sent either to the parking area or back to the GTCC LLW receiving, preparation, and shipping facility. Decontamination of the transport vehicle and empty cask will be accomplished at the storage facility track bay or the receiving, preparation, and shipping facility.

At the assay/inspection cubicle. the containers are first remotely examined, labeled. logged, and recorded. An assay/inspect unit operation is used to determine radioactivity, physical properties, and other parameters that are needed to classify the waste for disposal. Various devices such as SGS and PAN assay instruments may be used. After radiological examination, the containers are weighed and measured to determine waste density.

The vault safely stores the drums for the desired period. A monitoring unit operation continuously monitors the storage confinement system and will be able to determine when corrective action needs to be taken to maintain safe storage conditions. Monitoring includes any potential leakage of drums.

Operations involving storage of GTCC LLW waste drums are accomplished remotely. Shielding is provided to reduce the worker's exposure to radiation.

Operation steps for shipment of the drums out of the storage facility is the reverse of the incoming drum operation steps discussed above. The storage facility does not generate secondary waste. 


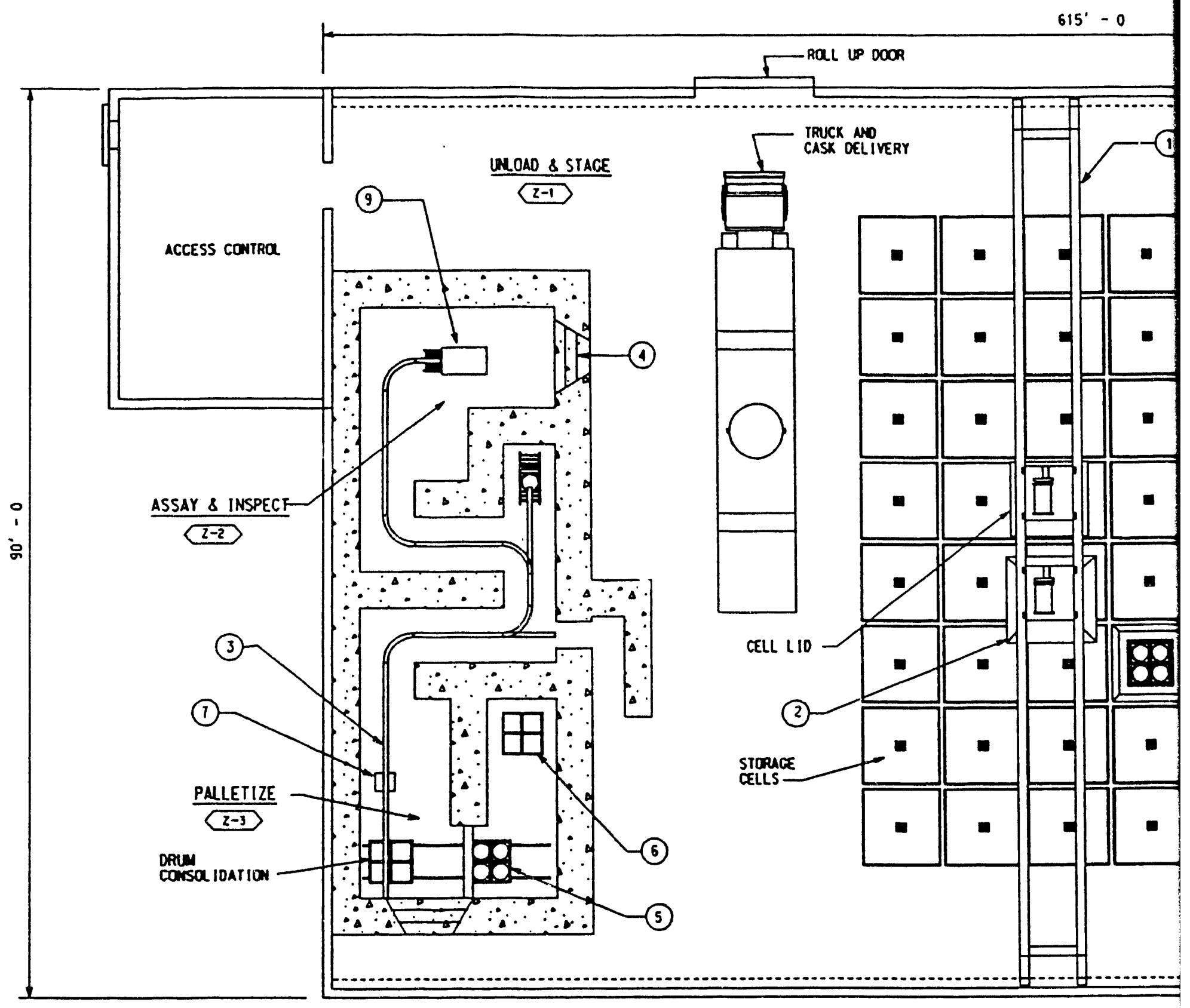

\section{NOTES:}

1. TO LEET THE STORACE REOUIRELENTS FOR THE LARCE FACILITY. SEVEN OF THE BUILDINCS SHOM ABOVE VILL BE REQUIRED. EACH LABCE BUILOING HAS 578 VAUTIS.

2. TO KEET THE STORACE REOUIREIENTS FOR THE SWLL FACILITT. TO OF THE QUILDINCS VILL BE REOUIRED. VITH THE EXCEPTION HHAT THE SUALL BUILOING HAS ONCY ONE TRUCX BAY. ASSAY/INSPECT ND PALLETIZATION AREA. EACH SWULL BUILOING HAS 492 vall TS

3. OKY ONE SET OF CRANES. ASSAY/INSPECT ANO PALETIZING SYSTEMS IS PROVIDED. IT IS ASSUED THAT THESE SYSTELS VILL BE WOVED FROM OKE BUILOING TO NWTHER.
VAULT STORAGE (COST MODI LARGE FACILITY FLOOR PI

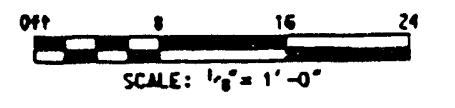

Figure 11-1. GTCC LLW vault storage facility plan (cost module Z). 


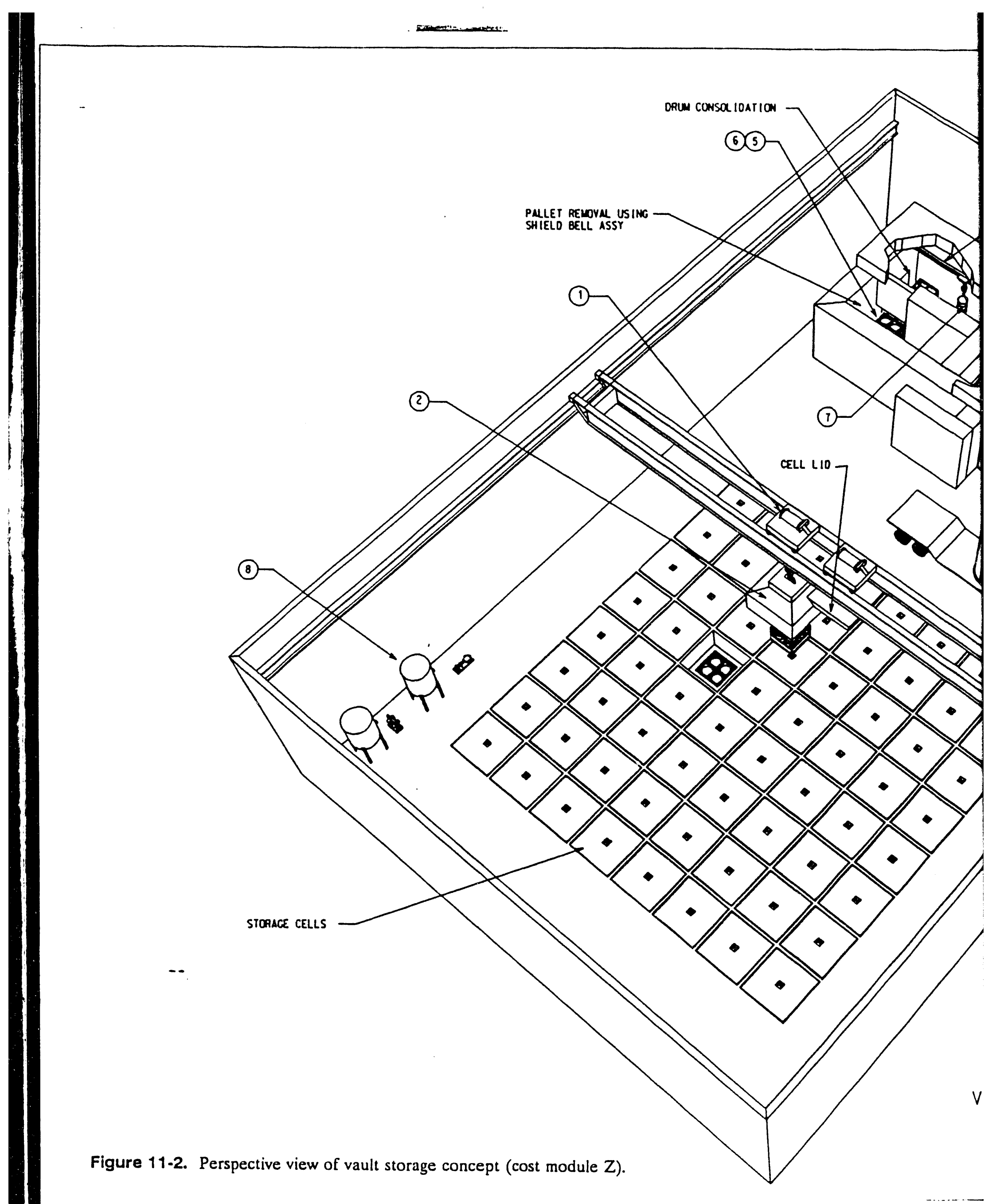




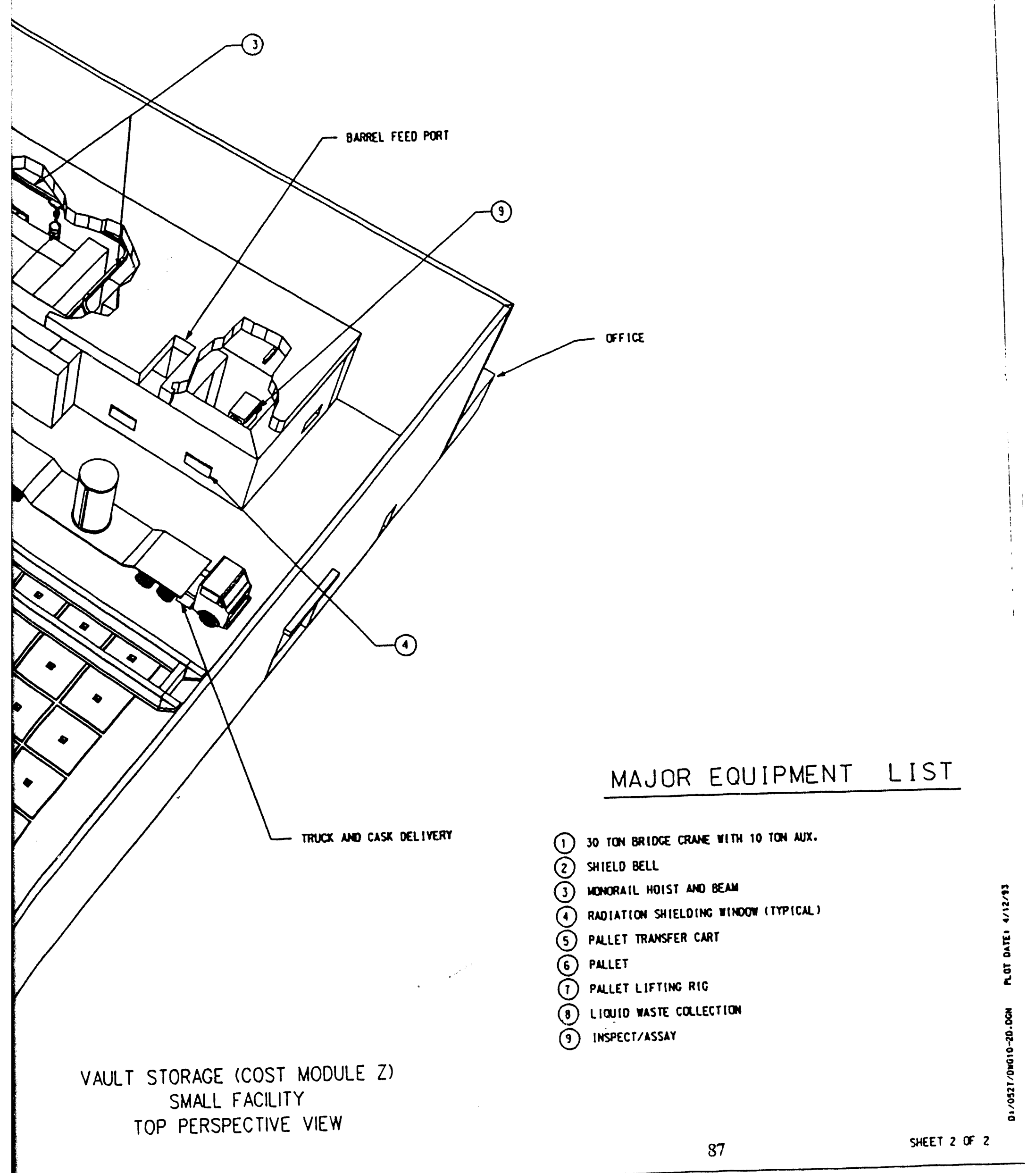




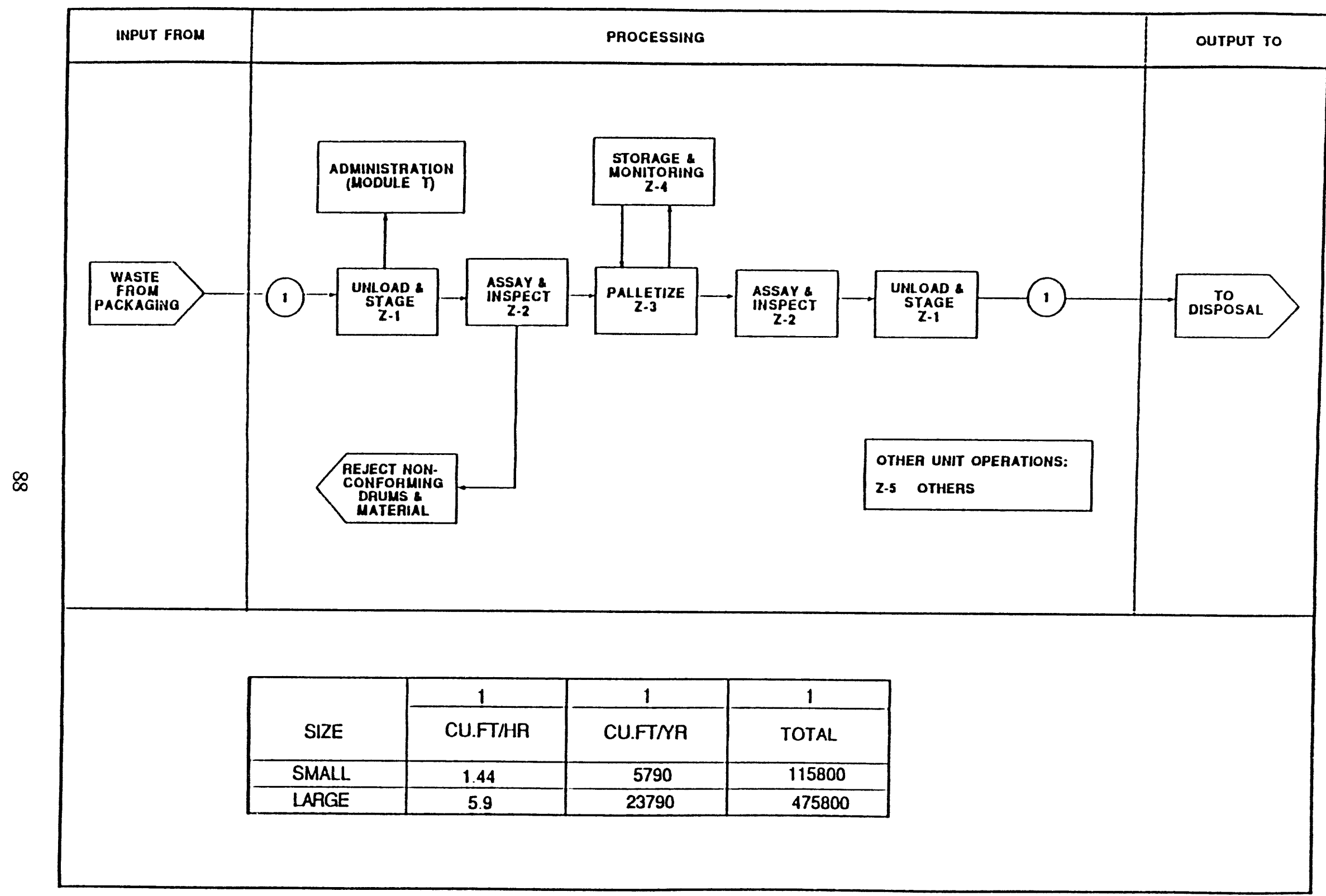

Figure 11-3. Process functional diagram for GTCC LLW vault storage facility (cost module Z). 


\subsubsection{Facility Integration}

This facility interfaces with the site communication and alarm systems including telephone, evacuation, fire, security alarm, and public address systems. Operations and maintenance consumables including decontamination agents and personal protective equipment, must be purchased. Facility input is the incoming waste containers in casks mounted on transportation trucks. The output is the same as the input.

\subsection{Cost Bases, Assumptions and Assessments}

General cost bases and assumptions are given in Appendix A. Facility-specific items are discussed below:

- Estimated operating staff is shown in Table 11-1.

- Small and large facility capacities and unit costs are shown in Table 11-2.

\subsection{Cost Summaries}

Cost summaries for the GTCC LLW vault storage facility cost modules are shown in Table 11-3. Histogram for cost vs. capacity is shown in Figure 11-4.

- Each storage vault holds 16 drums, palletized in 4 drums.

- Because of simplicity of design, it is assumed that design cost is $10 \%$ of the facility construction cost. Inspection cost is $3 \%$. 
Table 11-1. Fstimated operating staff for GTCC LLW vault storage facility loading/unloading period (cost module $\mathrm{Z}$ ).

Unit

Operation

Z-1

Z-2

Z-3

Z-4

Z-5
Description

Unload and Stage

Assay and Inspect

Drum Transfer

Storage and Monitoring

Others

Total

\section{Small}

(FTE)

Large

(FTE)

$\begin{array}{rr}2 & 8 \\ 2 & 8 \\ 2 & 8 \\ 2 & 3 \\ 2 & 3 \\ 10 & 30\end{array}$

Table 11-2. Capacity and unit cost for GTCC LLW vault storage facility (cost module Z).

\begin{tabular}{|c|c|c|c|c|c|c|}
\hline $\begin{array}{l}\text { Module } \\
\text { Coxde }\end{array}$ & $\begin{array}{c}\text { Module } \\
\text { Description }\end{array}$ & Facility & $\begin{array}{l}\text { Life Cycle Cost } \\
(\$ \times 1000)\end{array}$ & $\begin{array}{l}\text { Cappacity } \\
\left(f^{3} / \mathrm{Mr}\right)\end{array}$ & 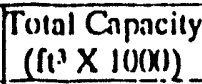 & $\begin{array}{l}\text { Unit Cost } \\
\left(\$ /\left[t^{3}\right)\right.\end{array}$ \\
\hline$z^{-}$ & 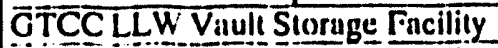 & Smail & 303,884 & 1.44 & - & $-\$ 2,617$ \\
\hline$\overline{\mathbf{Z}}$ & ÖICC LLW Vauli Slorige Tacility & Lirgec & 880,529 & 5.90 & $47 \pi$ & 51,8711 \\
\hline
\end{tabular}


Table 11-3. PLCC estimate summary for GTCC LLW vault storage facility (cost module Z).

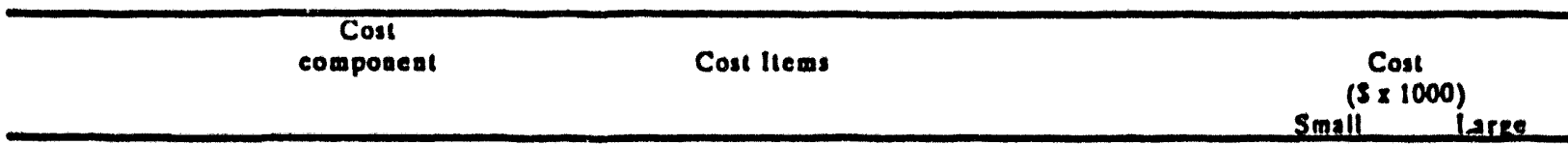

12 Equipment costs

1.3 Installation costs

1.4 Project managemeat before title I ( $10 \%$ of 1.1 tbrough 1.3)

i.s Contingeacy

( $25 \%$ of 1.1 (brough 1.4 )

Subtotal 1.0

Demonstration costs

2.1 Manpower costs during demonstration

$\begin{array}{ll}21 \text { Desiga cost } & (30 \% \text { of 2.5) } \\ 2.3 \text { Inspection cost } & (1 \% \text { of 2.5) } \\ \text { 2.4 Project management } & (10 \% \text { or 2.5) }\end{array}$

$\begin{array}{ll}2.5 .1 & \text { Building structure costs } \\ 2.52 & \text { Equipmeal costs } \\ 2.5 .3 \quad \text { Indirect } & (2990 \text { of } 2.5 .123 .52)\end{array}$

Subtotal of 2.5

2.6 Construction manazement costs ( $17 \%$ of 2.5$)$

2.7 Maangement Reserve ( $10 \%$ of 2.5 )

$\begin{array}{ll}2.7 \text { Maaagement Reserve } & (10 \% \text { of } 2.5) \\ 2.8 \text { Contingency } & (25 \% \text { of } 2.1 \text { through 2.7) }\end{array}$

Subtotal 2.0

Production facility construction costs

3.1 Desiga cost

3.2 Inspection cost

3.3 Project management

( $89 \%$ of 3.4)

( $3 \%$ o( 3.4 )

( $10 \%$ of 3.4 )

3.4 Construetion cost $\begin{array}{ll}3.4 .1 & \text { Building structure costs } \\ 3.42 & \text { Equipment costs } \\ 3.4 .3 & \text { lodireet }\end{array}$

( $29 \%$ or 3.4 .183 .4 .2$)$

Subtotal of 3.4

3.5 Construction management

3.6 Managemeat Reserve

( $17 \%$ of 3.4)

( $10 \%$ of 3.4 )

3.7 Coatingency

( $25 \%$ of 3.1 through 3.5)

Subtotal 3.0

4.0

Operations Budget Funded Activities (See SecL 7)

4.1 Conceptual design (1.5\% of 3.0)

+2 Sifety assumes

( $1.5 \%$ of 3.0$)$

4.3 NEPA permilting (\$ 6 Mill for EIS. SI Mill for EA)

4.4 Preporation for operations ( $100 \%$ ol 5.0$)$

4.5 Project Management ( $10 \%$ of 4.1 (hrough 4.4 )

Subtotal $\$ .0$

Toul Initial Cost $(1.0,2.0 .3 .0 \& 4.0)$

$\begin{array}{ll}s 0 & S O \\ s 0 & S O \\ s 0 & S O \\ S O & S O \\ S O & S O \\ S O & S O\end{array}$

Operatiag and maintainence costs (Loadiag / Ualosdios Period)

5.1 Anaual operntiag costs

S.2 Anoual utility costs

5.3 Annual material costs

S.4 Aunual maintaidence costs

5.5 Contingency

( $25 \%$ of 5.1 through 5.4 )

S.6 Subtotal $\mathbf{5 . 0}$

5.7 Total 20 year 0 \& $M$ cost (20 times Subtotal 5.0 )

so 50

so so

so so

so 50

so $\quad$ so

so 50

$50 \quad 50$

so so

SO SO

so so

so so so

$5.669 \quad 519,023$

$\$ 2.126 \quad 57.133$

$\mathbf{5 7 , 0 8 7 \quad \$ 2 3 . 7 7 8}$

$\$ 46,526 \quad \$ 163,732$

$\mathbf{\$ 8 . 4 1 0 \quad \mathbf { 2 0 } . 5 9 6}$

$\$ 15.931 \quad \mathbf{S 3} .455$

$\mathbf{5 7 0 . 8 6 7 \quad \mathbf { 2 3 7 . 7 8 3 }}$

$\$ 12.118 \quad 510.661$

$\$ 7.087 \quad \$ 23.778$

$584.467 \quad 582.095$

$5129,421 \quad 5434251$

$51.941 \quad 56.514$

S1.294 54.343

$\$ 6,000 \quad \$ 6,000$

$\$ 5.426 \quad 512.435$

$\$ 1 .+66 \quad 52.929$

$516.127 \quad 532271$

$5145,548 \quad 5466,472$

Tolal 20 yesr O $M$ cost (20 tiunes Subtoral 5.0)

6.0 Decontamination \& Decommissioning

$5210 \quad 54200$

$59 \quad 522$

$5694 \quad \mathbf{2 . 8 3 7}$

$51.398 \quad 52.389$

S1.085 $\mathbf{S . + 4 8 7}$

$\$ 5.426 \quad \$ 12,435$

$\$ 108,520 \quad 5+8,700$

$\$ 49,816 \quad \$ 17+, 337$

7.0 ROM Life cycle costs (20 years operation)

$\mathbf{3 0 3 , 8 8 4}$

5859.529 


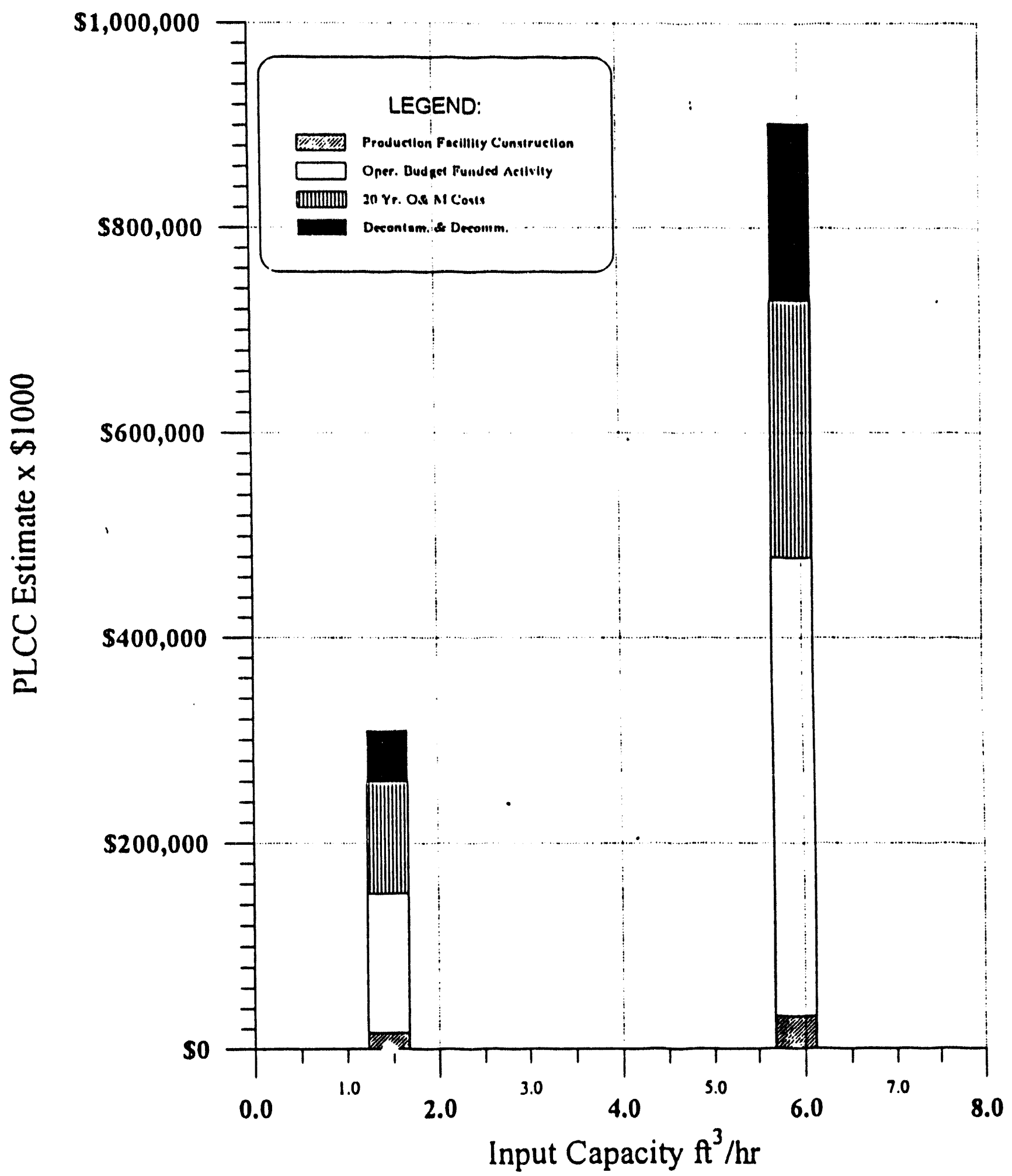

Figure 11-4. Cost versus capacity histogram for GTCC LLW vault storage facility (cost module Z). 


\section{SILO STORAGE FACILITY (COST MODULE MM)}

\subsection{Basic Information}

The GTCC LLW silo storage facility, shown in Figure 12-1, is used in conjunction with the receiving, preparation, and shipping module of the GTCC LLW treatment facilities. In addition, the facility can accept packaged waste from generators or other sources. The facility receives GTCC treated waste in metal drums and holds them in shielded storage silo for long-term storage. The facility is capable of receiving waste having high gamma radiation and requiring remote handling. The unit operations that accomplish these functions are shown in Figure 12-2.

\subsection{Technical Bases and Assumptions}

\subsubsection{Functional and Operational Description}

A transport vehicle brings drums loaded in a radiation shielding cask to the storage yard where prefabricated storage silos are located. The designated storage silo is prepared in advance to accept the drums.

At the storage yard, an unload and stage unit operation receives and inspects the transportation vehicle and shield cask, and removes the cask cover. Using remote handling techniques the GTCC waste drum is transferred from the transportation cask to a storage pallet. When a drum removal operation is completed, the pallet is remotely placed inside the silo. The empty cask and trailer is then inspected, the cask lid attached, and the trailer is sent either to the parking area or back to the treatment facility.

The vault safely stores the drums for the desired period. A monitoring unit operation continuously monitors the storage confinement system and will be able to determine when corrective action needs to be taken to maintain safe storage conditions. Monitoring includes any potential leakage of drums.

Operation steps for shipment of the drums out of the storage facility are the reverse of the incoming drum operation steps discussed above. The storage facility does not generate secondary waste.

\subsubsection{Facility Integration}

This facility interfaces directly with the GTCC LLW receiving, preparation, and shipping facility (cost module BB) or waste generator facilities. Operations and maintenance consumables, including personal protective equipment, must be purchased. Facility input is the incoming GTCC LLW drums in casks mounted on transport devices. The output is the same as the input. The facility includes security fence, monitoring, and security and access control features.

\subsection{Cost Bases, Assumptions and Assessments}

General cost bases and assumptions are presented in Appendix A. Facility-specific items are discussed below:

- Each storage silo holds 16 drums in four pallets. 


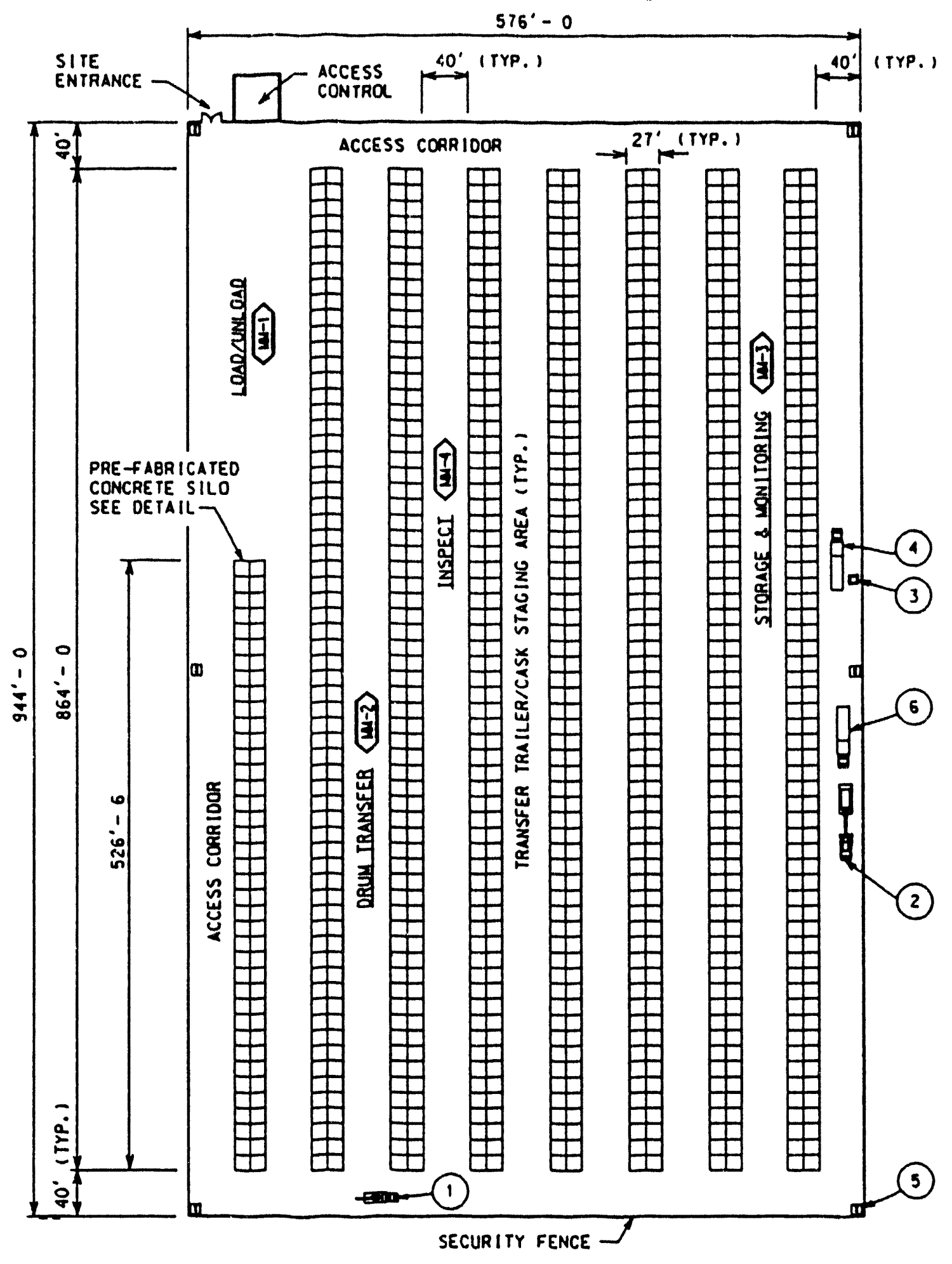

MAJOR EQU

(1) NOBILE BOOL

(2) TOW TRACTOA

(3) SHIELD BELL

(4) TRANSFER Ti

(5) ENVIRONIEN SYSTEN

(6) TRASPORTABI

PRE-FABRICATED SILO STORAGE (COST MODULE MM)

SMALL FACILITY SITE PLAN

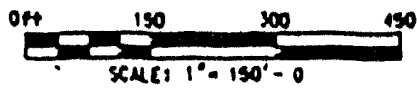

Figure 12-1. GTCC LLW silo storage facility plan (cost module MM). 


\section{IR EOUIPMENT LIST}

DBILE BOOM CRANE

\section{TRACTOR}

HIELD BELL

\section{RANSFER TRAILER}

NVIRONIENTAL AND SECURITY YSTEN

RASPORTABLE ASSAY/INSPECT TRAILER
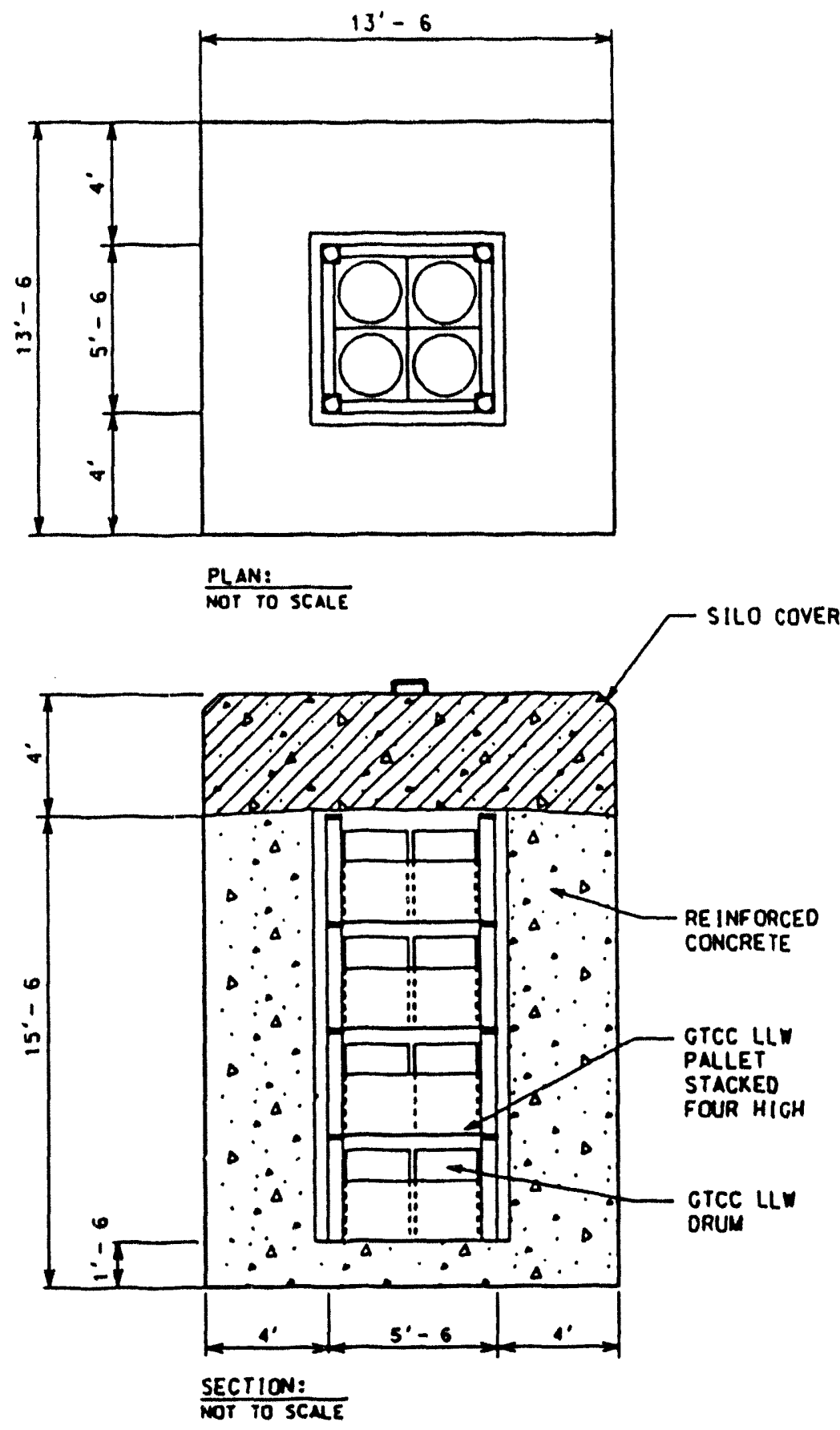

PREFABRICATED CONCRETE SILO DETAIL 


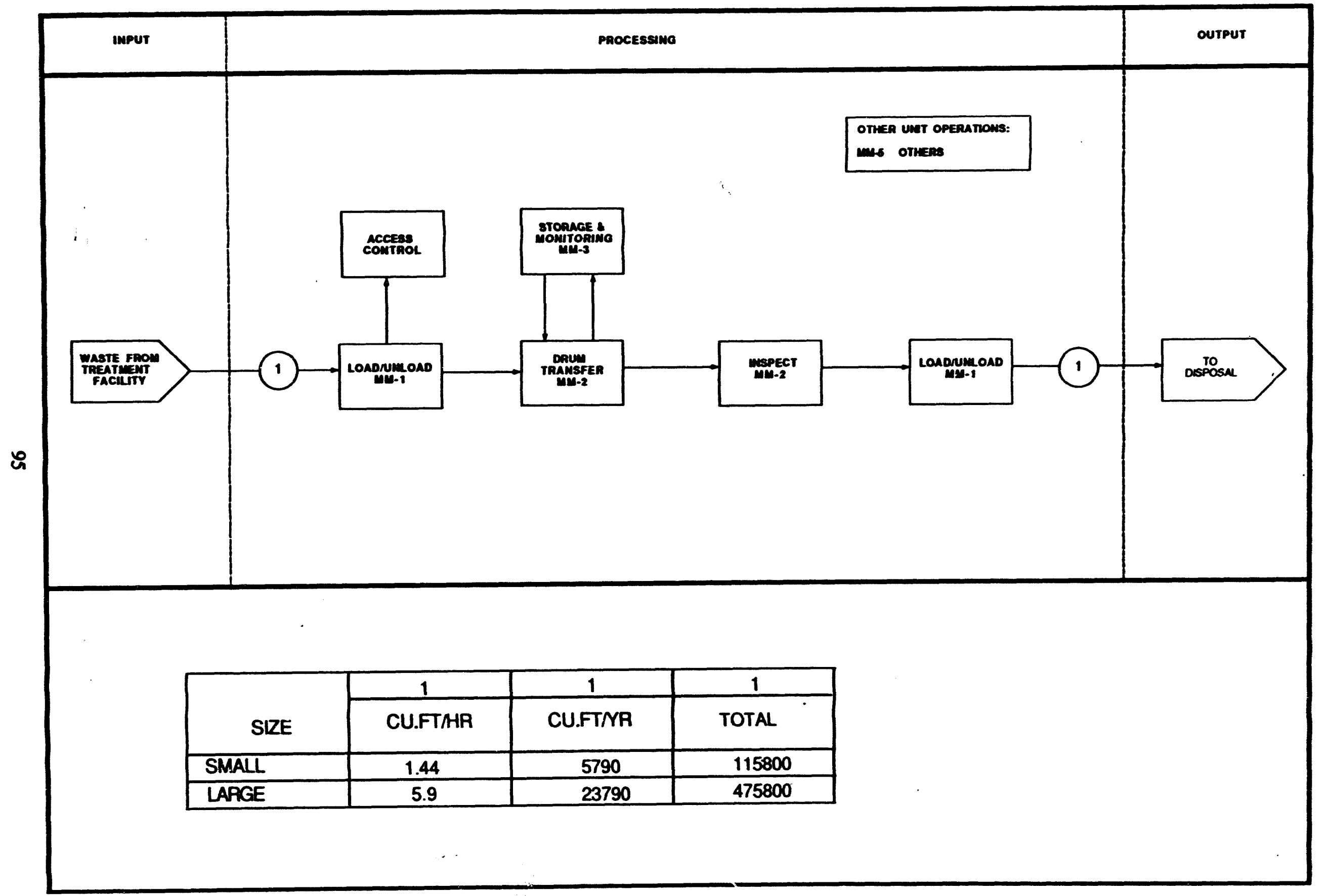

Figure 12-2. Process functional diagram for GTCC LLW silo storage facility (cost module MM). 
- Estimated operating staff is shown in Table 12-1.

- Small and large facility capacities and unit costs are shown in Table 12-2.

- It is assumed that prefabricated silos will be a complete package supplied by vendors. Hence, design cost is estimated at $6 \%$ of the silo construction costs. Inspection cost is $2 \%$

- Decommissioning costs are estimated at $\$ 1,500$ per fabricated concrete silo.

\subsection{Cost Summaries}

A cost summary for the prefabricated dry storage facility cost module is shown in Table 12-3. A histogram of cost vs. capacity is given in Figure 12-3. 
Table 12-1. Estimated operating staff for GTCC LLW silo storage facility loading/unloading period (cost module MM).

Unit Description

Small (FTE)

Large (FTE)

MM-1 Load/Unload

MM-2 Drum Transfer

MM-3 Storage and Monitoring

MM-4 Inspect

MM-5 Others

Total

\begin{tabular}{rr}
3 & 12 \\
4 & 16 \\
2 & 4 \\
1 & 2 \\
1 & 4 \\
\hline 11 & $\frac{4}{38}$
\end{tabular}

Table 12-2. Capacities and unit costs for GTCC LLW silo storage facility (cost module MM).

\begin{tabular}{|c|l|r|r|r|r|r|}
\hline $\begin{array}{c}\text { Module } \\
\text { Code }\end{array}$ & \multicolumn{1}{|c|}{$\begin{array}{c}\text { Module } \\
\text { Description }\end{array}$} & Facility & $\begin{array}{c}\text { Life Cycle Cost } \\
(\mathbf{S X 1 0 0 0 )}\end{array}$ & $\begin{array}{c}\text { Capacity } \\
\left(\mathrm{ft}^{3} / \mathrm{hr}\right)\end{array}$ & $\begin{array}{c}\text { Total Capacity } \\
\left(\mathrm{ft}^{3} \mathrm{X} 1000\right)\end{array}$ & $\begin{array}{r}\text { Unit Cost } \\
\left(\mathrm{S} / \mathrm{f}^{3}\right)\end{array}$ \\
\hline MM & GTCC Silo Storage Facility & Small & 196,099 & 1.44 & 116 & $\mathbf{S 1 , 6 8 9}$ \\
\hline MM & GTCC Silo Storage Facility & Large & 610,505 & 5.90 & 476 & $\$ 1.283$ \\
\hline
\end{tabular}


Table 12-3. PLCC estimate summary for GTCC LLW silo storage facility (cost module MM).

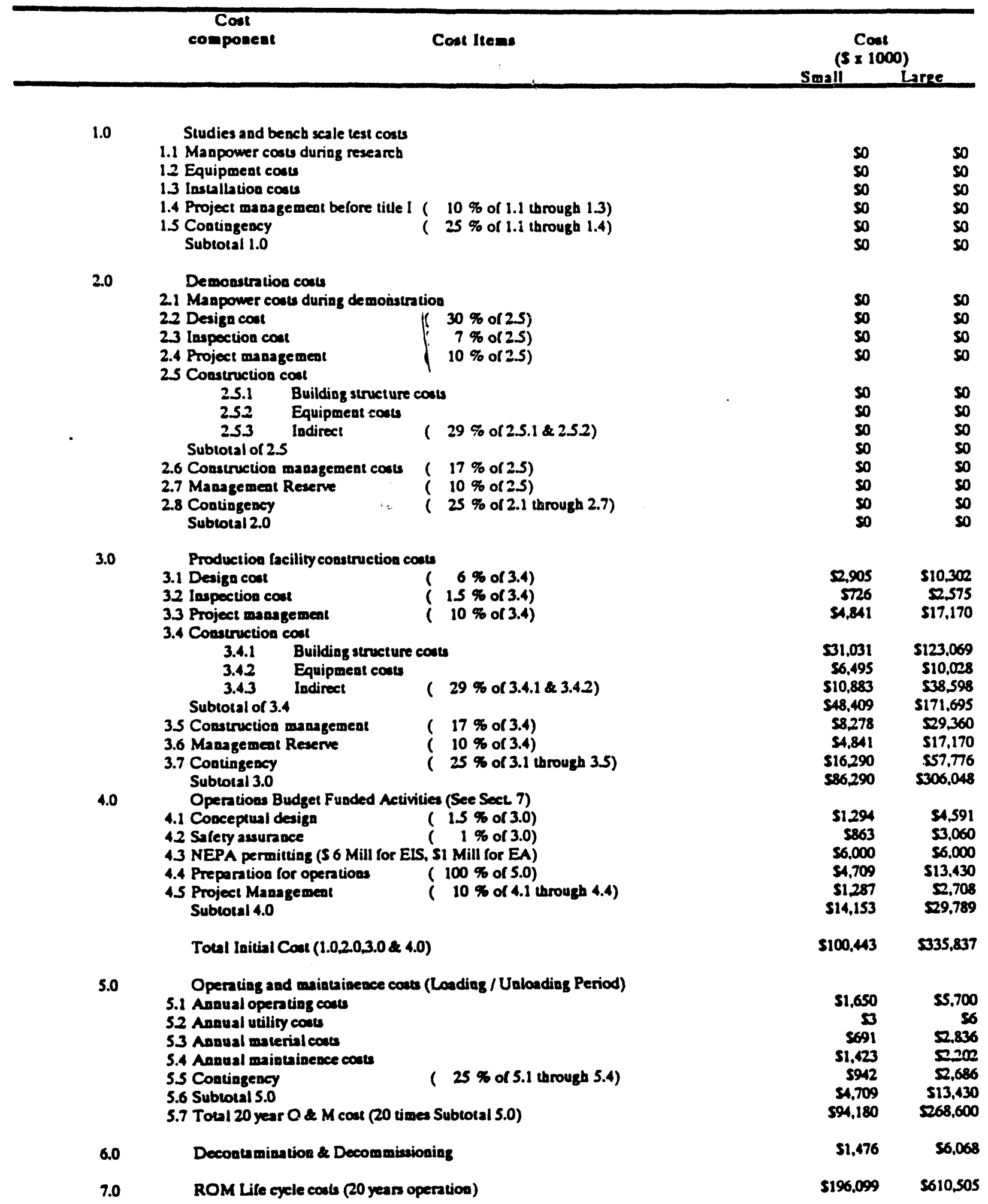




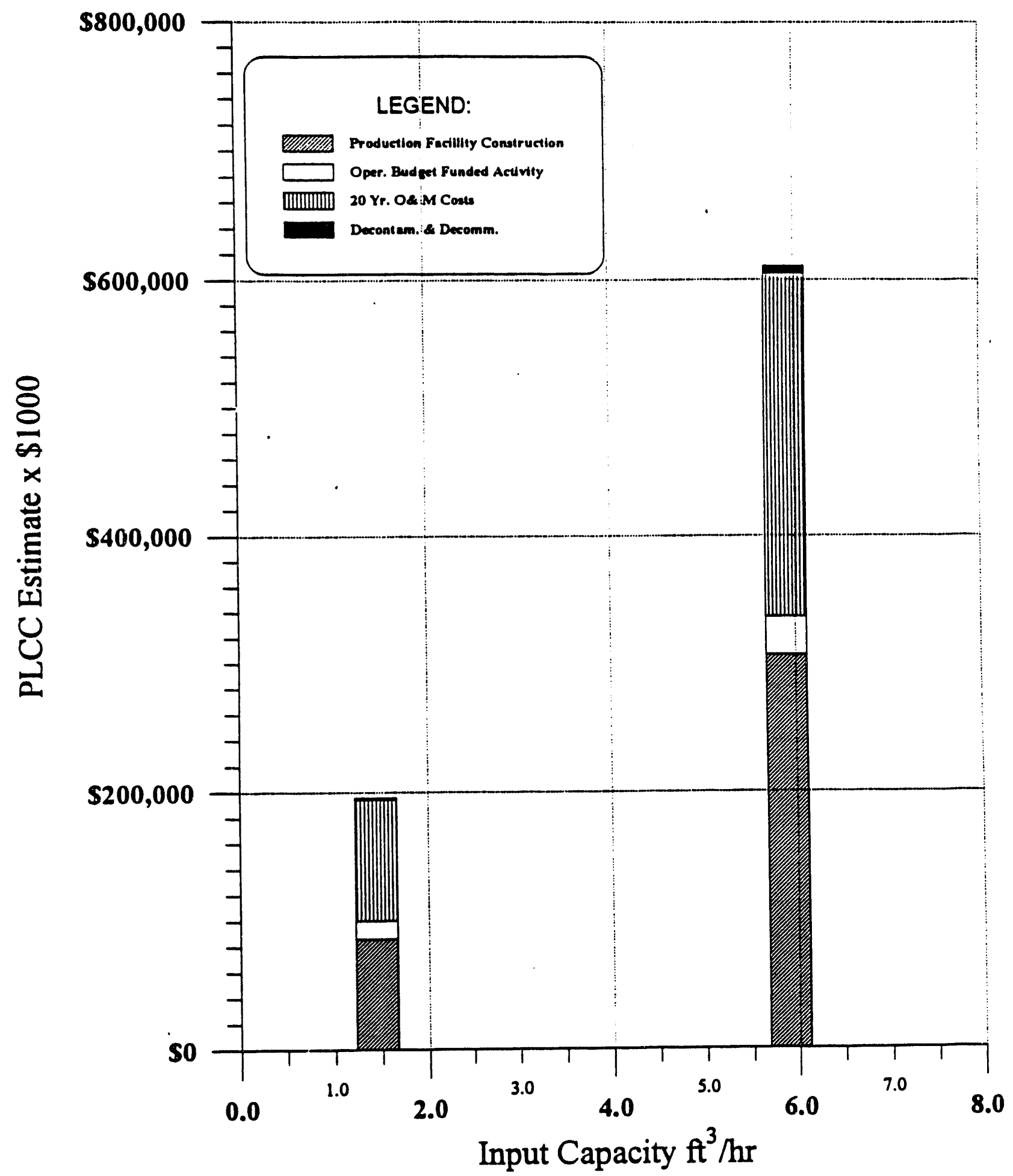

Figure 12-3. Cost versus capacity histogram for GTCC LLW silo storage facility (cost module MM). 


\section{HLW/GTCC LLW GEOLOGIC REPOSITORY (COST MODULE JJ)}

\subsection{Basic Information}

This facility consists of a deep geologic GTCC LLW repository that is an addition to an existing HLW repository. A planning cost estimate is based on rates quoted by $L$. Clark of Pacific Northwest Laboratory (PNL) for the modification of Yucca Mountain Facility, Nevada to allow GTCC LLW.

\subsection{Technical Basis and Assumptions}

It is assumed that a deep geologic repository facility will be identical to the Yucca Mountain Facility. The detailed basis and assumptions were generated by L. Clark. ${ }^{d}$

\subsection{Cost Basis, Assumptions, and Assessments}

A summary of the capital costs for disposal at Yucca Mountain is as follows:

1. Although the Yucca Mountain facility is not open, it is designated as the future storage facility for HLW. The DOE has not formally established a disposal cost for waste received at the Yucca Mountain Facility.

2. Assuming six cost elements and using the System Engineering Cost Analysis Model developed by L. Clark of PNL, 1990, the following costs are provided for base volume:

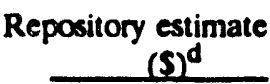

S)

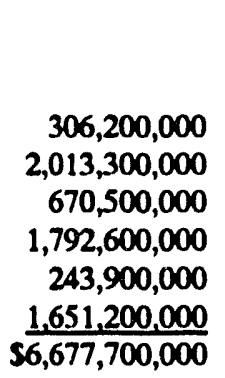

Incremental cost of an HLW repository allocated to GTCC LLW $(S)^{e}$

\begin{tabular}{r} 
Small (2) \\
\hline 500,000 \\
$88,700,000$ \\
$16,600,000$ \\
$53,900,000$ \\
0 \\
0 \\
$\$ 159,700,000$
\end{tabular}

Large (2)

$$
\begin{array}{r}
6,000,000 \\
893,000,000 \\
241,100,000 \\
455,100,000 \\
8,500,000 \\
\$ \$ 1,604,300,000
\end{array}
$$

3. The amount of waste to be disposed of for the small facility (base volume/high density packaging scenario) is approximately $95,480 \mathrm{ft}^{3}$. This includes 5,194 drums and 6,775 canisters $(9$ in. square $\times 15 \mathrm{ft})$.

4. The amount of waste to be disposed for the large facility (high volume/low density packaging scenario) is approximately $919,600 \mathrm{ft}^{3}$. This includes 94,977 canisters and 16,085 drums.

d. Unpublished research by L. L. Clark of PNL, 1990.

e. These capacities are based on L. Clark's research that is used as the baseline capacity for cost module JJ. 
5. Estimated incremental capital cost for a small capacity GTCC LLW disposal facility to be augmented to the Yucca Mountain HLW Repository $\left(\$ 159,700,000+95,480 \mathrm{ft}^{3}\right)$ is approximately $\$ 1,673 / \mathrm{ft}^{3}$. Operating and other noncapital related cost estimates (items 5 and 6 in Table 16-3) are obtained from the intermediate depth disposal (small facility cost module kk). Accordingly, these costs are estimated to be approximately $\$ 1,618 / \mathrm{ft}^{3}$ $(187,413,000+116,000)$.

6. Estimated incremental capital cost for a large GTCC LLW disposed facility to augmented to the Yucca Mountain HLW Repository $\left(\$ 1,604,300,000+919,600 \mathrm{ft}^{3}\right)$ is $\$ 1,746 / \mathrm{ft}^{3}$. Operating and other noncapital related cost estimates (items 5 and 6 in Table 16-3) are obtained from the intermediate depth disposal (large facility cost module $\mathrm{KK}$ ), and is approximately $\$ 632 / \mathrm{ft}^{3}(300,850,000+476,000)$.

\subsection{Cost Summary}

The total PLCC estimate for the small cost module is $\$ 3,291 / \mathrm{ft}^{3}$ based on a disposal capacity of $95,480 \mathrm{ft}^{3}$.

The total PLCC estimate for the large cost module is $\$ 2,378 / \mathrm{ft}^{3}$ based on a dispusal capacity of $919,600 \mathrm{ft}^{3}$. 


\section{DISPOSAL FRONT-END SUPPORT FACILITY (COST MODULE O)}

\subsection{Basic Information}

The disposal front-end support facility is used in conjunction with the engineered shallow land and intermediate depth disposal facilities (cost modules $P, Q, R$, or $K K$ ) and provides all the necessary common functions for disposal of GTCC-LLW. The disposal front-end support facility unit operations include truck loading/unloading areas, administrative offices, analytical laboratory facilities, and truck inspection and washdowns. Unit operations are given in Figure 14-1. In addition to small, medium and large size facility, a minimum size disposal facility is also estimated.

\subsection{Technical Basis and Assumptions}

\subsubsection{Functional and Operational Description}

All containers that arrive at the disposal front-end support facility are assumed to be 55-gallon drums. The drums arrive in a transport vehicle, are unloaded using a forklift or overhead bridge crane, and placed in a staging area. The containers are visually examined, labeled, logged, recorded, and sent to inspection and assay. At the inspection/assay unit, the category of the received waste is verified against the results obtained from the back-end treatment or storage facilities. After inspection, the drums are sent to the disposal facility (modules $P, Q, R$, or KK).

The technical basis and requirements for all disposal front-end support facilities are generally the same as those outlined in Section 2 and 3, and Appendix A, except that the assay/inspection and certification functions are for verification purposes only.

\subsubsection{Facillty Integration}

Facility input includes trucks containing packaged waste from either the treatment or storage facilities. O\&M consumables including personal protective equipment must be purchased. Facility output consists of drums which are transferred to the disposal facilities.

\subsection{Cost Bases, Assumptions and Assessments}

General cost bases and assumptions are given in Appendix A. Facility-specific items are discussed below:

- Major equipment and facility cost items for this facility are based on data obtained from the Illinois LLW disposal facility license agreement of 1991.

- Estimated operating staff are shown in Table 14-1.

- A $\$ 1$ million allowance is made for the analytical instruments and components needed for a mixed-waste laboratory. Mixed-waste laboratory vendors have been consulted to ensure that the laboratory allowance is adequate. The crane cost is estimated based on vendor quotes.

- Minimum, small, medium, and large facility capacities and unit costs are shown in Table 14-2. 


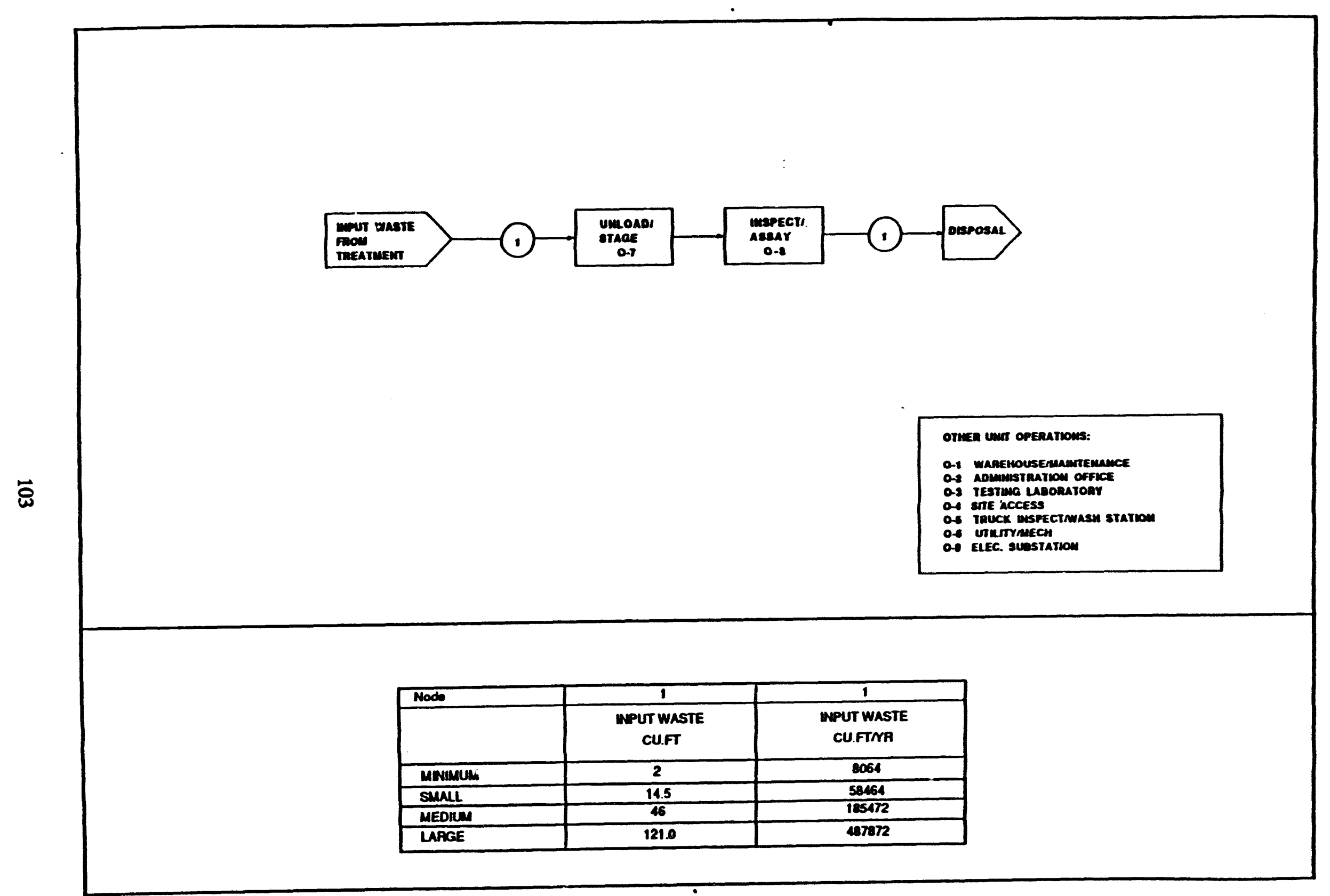

Figure 14-1. Disposal front-end facility process functional diagram (cost module $O$ ). 
Toble 14-1. Estimated operating staff for disposal front-end facility (cost module O).

\begin{tabular}{|c|c|c|c|c|c|}
\hline $\begin{array}{l}\text { Unit } \\
\text { Operation }\end{array}$ & Description & $\begin{array}{l}\text { Ainimum } \\
\text { (FTE) }\end{array}$ & $\begin{array}{l}\text { Small } \\
\text { (FTE) }\end{array}$ & $\begin{array}{l}\text { Medium } \\
\text { (FTE) }\end{array}$ & $\begin{array}{l}\text { Large } \\
\text { (FTE) }\end{array}$ \\
\hline $\begin{array}{l}0-1 \\
0-2 \\
O-3 \\
0-4 \\
0-5 \\
O-6 \\
0-7 \\
0-8 \\
0-9\end{array}$ & $\begin{array}{l}\text { Warehouse \& Maintenance } \\
\text { Administration/ Technical } \\
\text { Testing Laboratory } \\
\text { Site Access } \\
\text { Truck Inspection \& Washout } \\
\text { Unload/Stage } \\
\text { Inspect \& Assay } \\
\text { Utility \& Mechanical } \\
\text { Electrical Substation } \\
\text { Total }\end{array}$ & $\begin{array}{r}1 \\
5 \\
2 \\
4 \\
2 \\
1 \\
3 \\
1 \\
0 \\
19\end{array}$ & $\begin{array}{r}3 \\
24 \\
7 \\
12 \\
6 \\
6 \\
4 \\
2 \\
0 \\
64\end{array}$ & $\begin{array}{r}3 \\
35 \\
10 \\
18 \\
6 \\
9 \\
6 \\
2 \\
0 \\
89\end{array}$ & $\begin{array}{r}6 \\
50 \\
15 \\
31 \\
12 \\
12 \\
12 \\
3 \\
0 \\
141\end{array}$ \\
\hline
\end{tabular}

Table 14-2. Capacities and unit costs for disposal front-end facility (cost module 0 ).

\begin{tabular}{|c|c|c|c|c|c|c|}
\hline $\begin{array}{l}\text { Module } \\
\text { Code }\end{array}$ & Module Description & Facility & $\begin{array}{l}\text { Life Cycle Cost } \\
(\$ \times 1000)\end{array}$ & $\begin{array}{c}\text { Capacity } \\
\left(\mathbb{n}^{3} / \mathrm{mr}\right)\end{array}$ & $\begin{array}{l}\text { Total Capacity } \\
\left(\mathfrak{t}^{3} \times 1000\right)\end{array}$ & $\begin{array}{c}\text { Unit Cost } \\
\left(S / \mathrm{t}^{3}\right)\end{array}$ \\
\hline $\mathbf{0}$ & Disposał-Common Facility & Minimum & 147,208 & 200 & 161 & $\$ 913$ \\
\hline 0 & Disposał-Common Facility & Small & 314,840 & 14.50 & 1169 & $\$ 269$ \\
\hline $\mathbf{0}$ & Disposa-Common Facility & Medium & 441,535 & 46.00 & 3709 & $\$ 119$ \\
\hline $\mathbf{o}$ & Disposa/Common Facility & Large & 700,121 & 121.00 & 9757 & 572 \\
\hline
\end{tabular}




\subsection{Cost Summaries}

Cost summaries for the disposal front-end support facility is shown in Tables 14-3 and 14-4. A histogram for cost vs. capacity is given in Figure 14-2. 
Table 14-3. PLCC estimate summary for disposal common support facility (cost module 0 ).

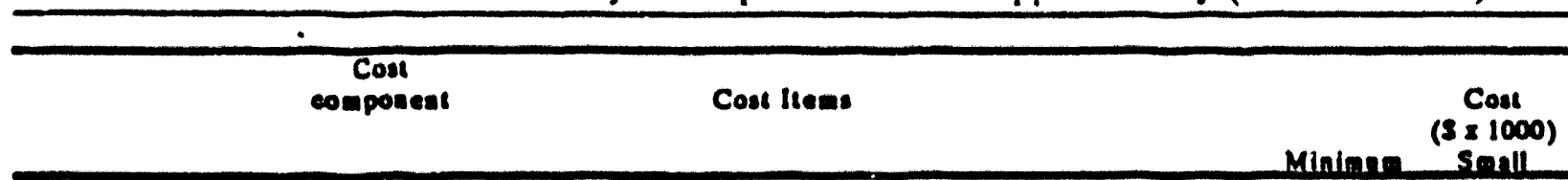

1.0

Studies and bench seale teal costs

1.1 Maupower costs during research

1.2 Equipanear cosls

13 Iastallation coss

1.t Project management before title I ( $10 \%$ of 1.1 througb 1.3)

is Contiagency

Subrotal 1.0

( $25 \%$ of 1.1 through 1.4 )

s.mill

20

Demoastration costs

21 Manpower costs duriag demonatration

$\begin{array}{ll}22 \text { Deniga coss } & (30 \% \text { ol } 25) \\ 23 \text { Imspetion cost } & (7 \% \text { ol } 25) \\ 24 \text { Project masagemeat } & (10 \% \text { ol } 25) \\ 25 \text { Coastruction cost } & \end{array}$

25.1 Buildios structure costs

25.2 Equipment costs

233 Indireet ( $39 \%$ or $25.1 \% 25.2)$

Subrotal of 25

26 Construction management cosss ( $17 \%$ of 23$)$

27 Maasgemeat Reserve (10\% ol 25).

28 Contingeacy $\quad(25 \%$ ol 21 (brough 27)

Subrolal 20

Production facility construction costs

3.1 Deaiga cost

$(18 \%$ of 3.4$)$

3.2 laspection cos

$(7 \%$ or 3.4$)$

3.3 Project nasagemeat

( $10 \%$ or 3.4$)$

3.4 Cosstruetios cost

3.4.1 Buildias strueture costs

3.4.2 Equipreat costs

3.4 .3 ladireet

$(29 \%$ o( 3.4.1 \& 3.4.2)

Subrotal of 3.4

3.5 Construction managemeat $\quad(17 \%$ of 3.4$)$

3.6 Managemeal Reserve ( $10 \%$ of 3.4 )

3.7 Contiagency

Subrotal 3.0

( $25 \%$ of 3.1 (trrough 3.5 )

Operations Budget Fuaded Activitiea (See Sect. 7)

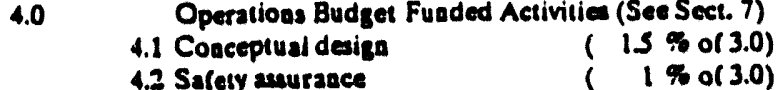

4.2 Saleby aunurance

( $1 \%$ o( 3.0$)$

4.3 NEPA permitting (\$6 Mill for ELS. S1 Mill for EA)
4.4 Proparatioa for operations ( $100 \%$ of 5.0 )

45 Projer Manazemeat

( $10 \%$ of t.1 (hrough 4.4)

Subtotal 4.0

Total Iaitial Cout $(1.0 .20 .3 .0 \& 4.0)$

Operatiag and maintaineace costs (Loading / Ualoading Period)

5.1 Annual operatias costs

5.2 Anaual utility costs

5.3 Anousl material costs

5.t Aan del maiacaiaesce costs

5.5 Contingency

( $25 \%$ or 5.1 through 5.4)

S.6 Subrotal 5.0

5.7 Total 20 year $O \& M$ cost (20 timea Subrotal S.0)

$\begin{array}{ll}90 & 50 \\ 0 & S 0 \\ 0 & S 0 \\ 0 & S 0 \\ 0 & S 0\end{array}$

Deconatamiastion \& Decommisaionias

-

31.413

SA,433

54.202

50.518

56.500

$\$ 3.176 \quad \mathbf{S 3 . 1 0 4}$

$\$ 14.127 \quad \$ 13.806$

$2.416 \quad 52361$

$\$ 1,413 \quad \$ 1381$

$\$ 5.372 \quad \$ 5.250$

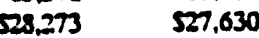

ROM Lile gyele costs (20 years operation)

2

SH24 SH14

$\mathbf{S 2 8 3} \quad \mathbf{S 2 7 6}$

$5.144 \quad 513.120$

s58s S1.381

$\$ 6,436 \quad S 1 S .191$

$\$ 4,709 \quad \mathbf{2 1 2 8 2 8}$

$\$ 2,660$

51

5282

$\$ 1.172$

$\$ 1,029$

$\$ 5.144$

$\$ 102880$

59,619

$51+7,208$ $\mathbf{5 8 . 9 6 0}$

5

$\mathbf{5 6 2}$

$\$ 1.168$

52624

$\$ 13,120$

5062,400

$\$ 9.619$

$\$ 14,840$ 
Table 14-4. PLCC estimate summary for disposal common support facility (cost module O).

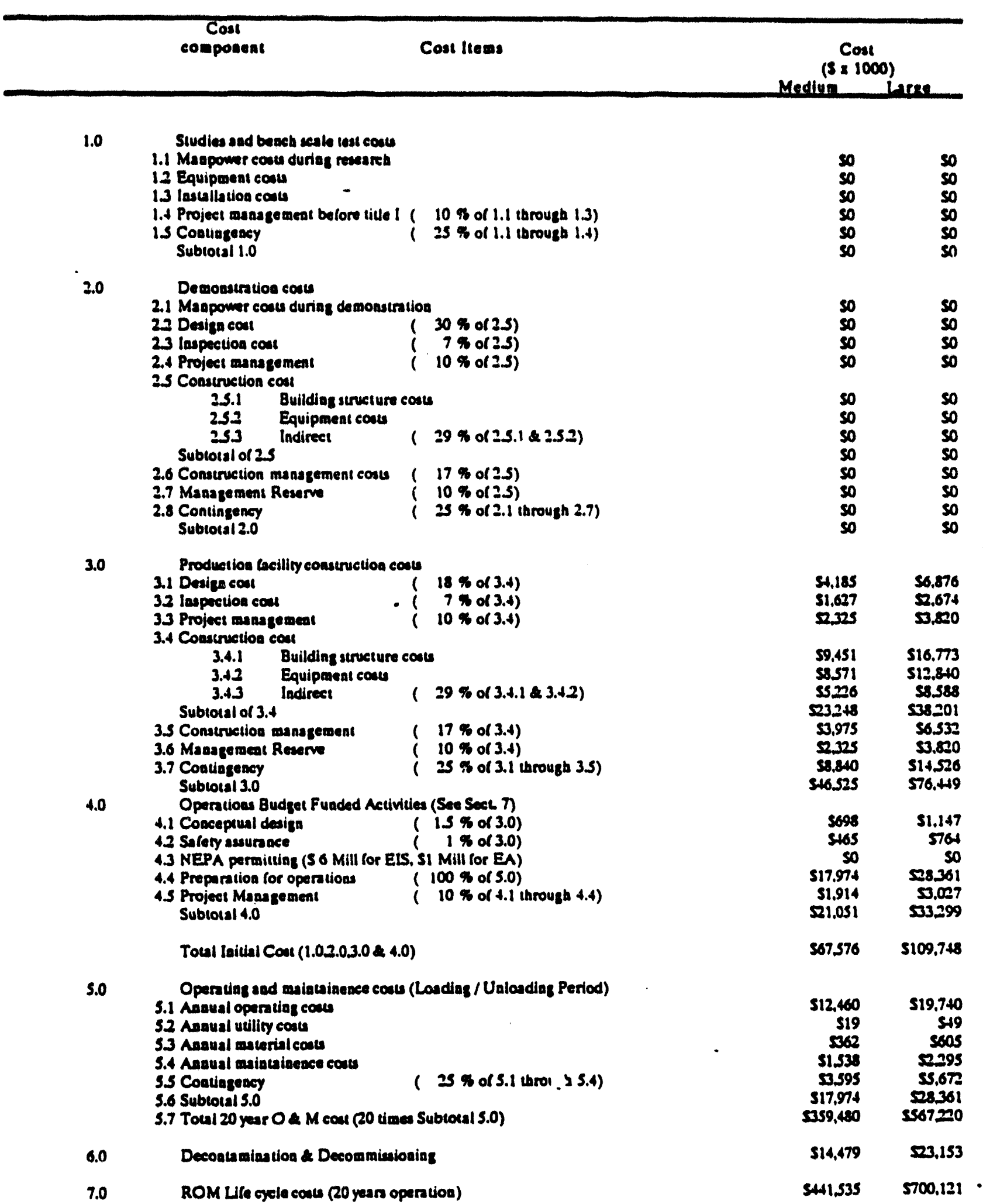




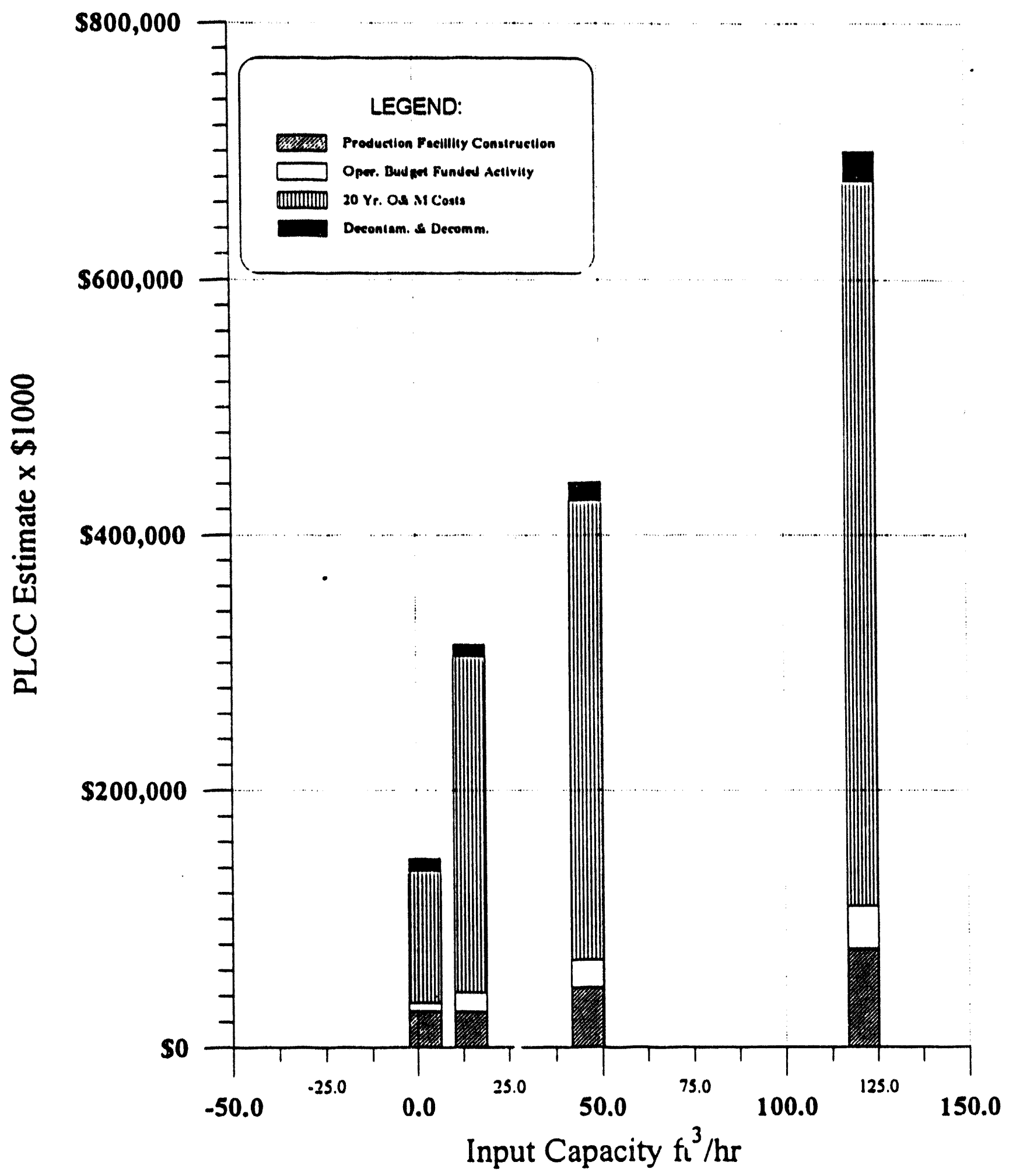

Figure 14-2. Cost vs. capacity histogram for disposal front-end facility (cost module 0 ). 


\section{FNGINEERED DISPOSAL FACILITIES (COST MODULES P AND Q)}

\subsection{Basic Information}

The engineered disposal facilities should be used in conjunction with the front-end support facility (see cost module $\mathrm{O}$ ) or as an addition to existing facilities where similar functions are already available. The facility consists of engineered disposal units that are based on the Illinois LLW disposal facility design, shown in Figure 15-1, which uses an earth-mounded concrete cell concept (refer to the Illinois LLW facility's license application of 1991). Engineered disposal facilities for radioactive (non-RCRA) waste and mixed (radioactive and hazardous) waste are essentially the same with the exception that a mixed waste disposal unit has a double leachate collection system in compliance with the RCRA requirements. Cost module $P$ is applicable to non-RCRA waste while cost module $Q$ is for RCRA mixed waste. Unit operations for both types of facilities are given in Figure 15-2.

The unit operations include receiving the inspected drums from the front-end facility, placing the drums into concrete canisters, and constructing the disposal units that will house incoming concrete waste canisters. Disposal unit construction includes foundation and monitoring system, concrete vaults, and earth-mound covers. Construction of the facilities is intended to be a continuous process concurrent with the placement of the canisters. Both disposal facilities (cost modules $\mathbf{P}$ and $Q$ ) are designed for long-term endurance and monitoring. In addition, the mixed waste disposal facility (module Q) is designed to meet RCRA standards and is equipped with a secondary leachate collection system.

\subsection{Technical Basis and Assumptions}

\subsubsection{Functional and Operational Description}

The drums received from the disposal front-end support facility are packaged into concrete canisters that are then sealed with grout. The canisters are transported to the disposal units for placement. Each disposal unit comprises a double row of concrete cells with an access aisle between the two rows. Concrete canisters that arrive from the packaging area are placed in a cell via crane or forklift in the access aisle and stacked three canisters high. Once the cell is full, it is backfilled with a sandy material and sealed with concrete. A concrete cover is concurrently constructed over the sealed cells.

The cells are capped with an earth mound layer that is engineered to withstand long-term environmental and weathering effects. The layered cap consists of sandy drain layers placed directly over the cells, then an impervious clay layer, a high density polyethylene (HDPE) liner, and a second drain layer to deter seepage into the cells. The top layer consists of either subsoil and vegetative material or subsoil, bedding, and riprap. The monitoring system includes sensors that will detect any leakage from the cells.

The decontamination and decommissioning includes facility demolition and the disposal unit maintenance. Disposal unit maintenance is planned in two stages, each with two substages: shortterm maintenance comprised of closure and postclosure periods and long-term maintenance, which consists of active institutional care and passive institutional care.

Closure activities take place during the first two years after the facility ceases to accept waste. Closure includes decontamination of the facilities, initial demolition of building, site development, 


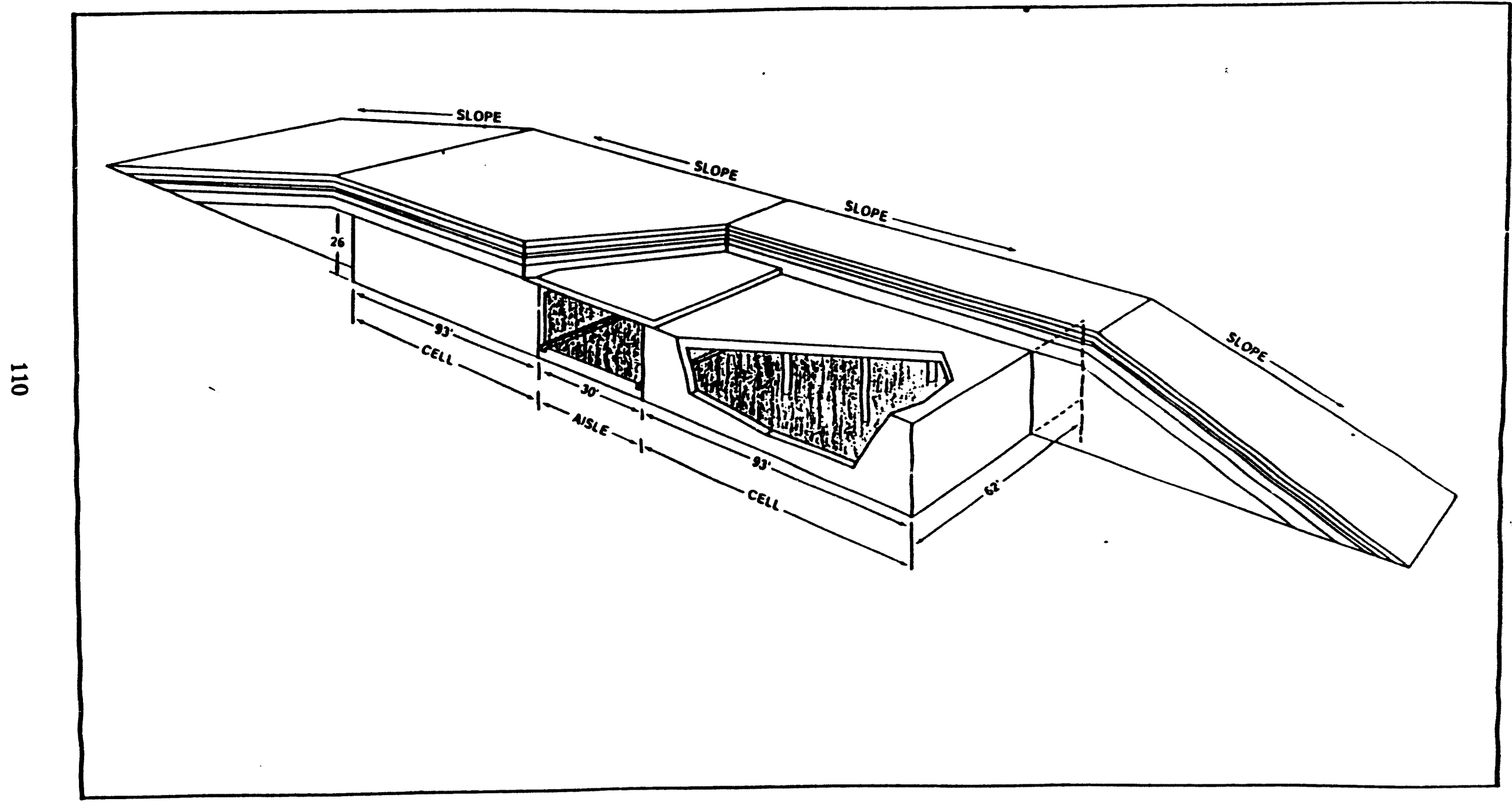

Figure 15-1. Engineered disposal facility plan (cost modules $\mathbf{P}$ and $\mathbf{Q}$ ). 


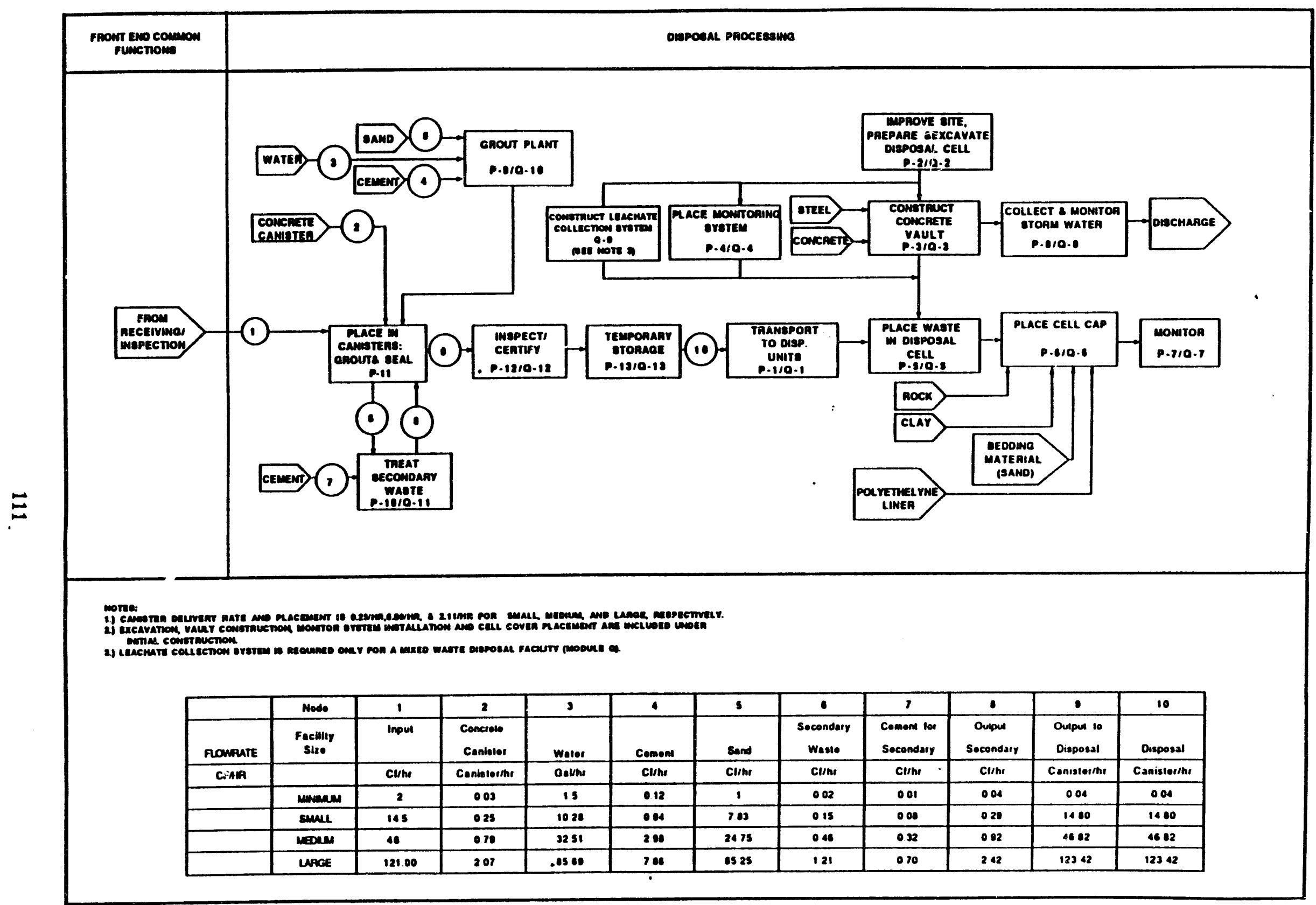

Figure 15-2. Process functional diagram for engineered disposal facility (cost modules $P$ and $Q$ ). 
closure of the cells, site remediation, and monitoring of the cell performance and groundwater. The first through tenth years after the facility ceases to accept waste are designated as the postclosure period. During this period, monitoring of the groundwater and cell performance will continue, as well as site remediation and development.

Active institutional care is planned for the 11th through 100th years, following the postclosure period. During this stage, any buildings not previously demolished are torn down and all site services are removed, in addition to ongoing monitoring activities from postclosure. The last stage, passive institutional care, extends from the 101st to the 300th year after the facility ceases to accept waste. Passive institutional care includes closure of the center aisles of the vaults, completion of the earth mound caps and site grading, removal of the retention ponds and retaining walls, and installation of passive drains. Long-term maintenance is discontinued after the $300^{\text {th }}$ year.

\subsubsection{Facility Integration}

Input interfaces include waste drums delivered from the front-end facility (refer to cost module O). O\&M consumables including empty concrete canisters, grout, sand, and personal protective equipment must be purchased. The facility is intended for permanent disposal of the waste and designed for long-te:m maintenance and monitoring as described above. No facility output is anticipated for a lengthy time period (at least 300 years).

\subsection{Cost Bases, Assumptions and Assessments}

General cost bases and assumptions are given in Appendix A. Facility-specific items are discussed below:

- Major equipment capital cost items are a forklift and a crane for placement of the drums into canisters and placement of filled canisters into the concrete cells. Costs for these items are based on vendor quotes.

- Estimated operating staff are shown in Table 15-1.

- Construction of the disposal units is a major cost item. A preconceptual design of one disposal unit that applies to all facilities, including concrete cells and cover design, was developed based on the design of the Illinois LLW Disposal Facility. A unit cost per cell was developed based on data from the Illinois facility, and an estimate was generated according to the rate of incoming waste and number of cells required for each small, medium, and large facility.

- Small, medium, and large facility capacities and unit costs are shown in Table 15-2.

- Estimates are based on a disposal facility in accordance with NRC criteria but a NRC license is not assi ned.

\subsection{Cost Summaries}

General cost summaries for the engineered disposal facilities are shown in Tables 15-3, 15-4, 15-5, and 15-6. Histograms for cost versus capacity are given in Figures 15-3 (cost module P) and $15-4$ (cost module Q). 
Table 15-1. Estimated operating staff for engineered disposal facility (cost modules $\mathbf{P}$ and $\mathrm{Q}$ ).

Unit

Operation

P-1/Q-1

P-2/Q-2

P-3/Q-3

$\mathrm{P}-4 / \mathrm{Q}-4$

P-5/Q-5

P-6/Q-6

P-7/Q-7

P-8/Q-8

Q-9

P-9/Q-10

P-10/Q-11

P-11/Q-12

P-12/Q-13

P-13/Q-14

\section{Description}

Transport to Disposal Units

Prepare \& Excavate Disposal Cell

Construct Concrete Vault

Place Monitoring System

Place Waste in Disposal Cell

Place Cell Cap

Monitor

Collect \& Monitor Storm Water

Construct Leachate Collect System

Grout Plant

Treat Secondary Waste

Place in Canister - Grout \& Seal

Inspect Certify

Temporary Storage

Total

\section{Minimum} (FTE)

Small Medium

(FTE) (FTE)

Large

(FTE)

\begin{tabular}{rrrr}
1 & 2 & 3 & 3 \\
0 & 0 & 0 & 0 \\
0 & 0 & 0 & 0 \\
0 & 0 & 0 & 0 \\
2 & 9 & 9 & 18 \\
0 & 0 & 0 & 0 \\
1 & 2 & 2 & 4 \\
1 & 2 & 2 & 4 \\
0 & 0 & 0 & 0 \\
5 & 8 & 8 & 16 \\
1 & 2 & 3 & 4 \\
4 & 15 & 15 & 30 \\
1 & 4 & 4 & 8 \\
0 & 0 & 0 & 0 \\
16 & 41 & 61 & 90 \\
\hline
\end{tabular}

Table 15-2. Capacities and unit costs for engineered disposal facility (cost module $P$ and $Q$ ).

\begin{tabular}{cllcccc}
\hline $\begin{array}{c}\text { Module } \\
\text { Code }\end{array}$ & Module Description & Facility & $\begin{array}{c}\text { Life Cycle Cost } \\
(\mathrm{SX1000)}\end{array}$ & $\begin{array}{c}\text { Capacity } \\
\left(\mathrm{ft}^{3} \mathrm{hr}\right)\end{array}$ & $\begin{array}{c}\text { Total Capacity } \\
\left(\mathrm{ft}^{3} \mathrm{X} \mathrm{1000)}\right.\end{array}$ & $\begin{array}{c}\text { Unit Cost } \\
\left(\mathrm{S} / \mathrm{ft}^{3}\right)\end{array}$ \\
\hline P & Engineered Disposal & Minimum & 331,126 & 2.00 & 161 & $\$ 2,053$ \\
P & Engineered Disposal & Small & 493,048 & 14.50 & 1169 & $\$ 422$ \\
P & Engineered Disposal & Medium & 887,595 & 46.00 & 3709 & $\$ 239$ \\
P & Engineered Disposal & Large & $2,147,516$ & 121.00 & 9757 & $\$ 220$ \\
& & & & & & \\
Q & Engineered Disposal & Minimum & 337,792 & 2.00 & 161 & $\$ 2,094$ \\
Q & Engineered Disposal & Small & 499,653 & 14.50 & 1169 & $\$ 427$ \\
O & Engineered Disposal & Medium & 901,566 & 46.00 & 3709 & $\$ 243$ \\
Q & Engineered Disposal & Large & $2,174,993$ & 121.00 & 9757 & $\$ 223$ \\
\hline
\end{tabular}


Table 15-3. PLCC estimate summary for engineered facility (cost module P).

\begin{tabular}{ccc}
\hline Cost & & \\
\hline componeat & Cost ltems & Cost \\
$(5 \times 1000)$ & Minimum \\
& & Small \\
\hline
\end{tabular}

Studies and bench scale test costs

1.1 Manpower costs during research

12 Equipmeat costs

1.3 Installation costs

1.t Project management before title I ( $10 \%$ of 1.1 through 1.3 )

i.s Contingency

( $25 \%$ of 1.1 through 1.4 )

Subtotal 1.0

( $25 \%$ of 1.1 (hrough 1.4)

Demonserstion costs

2.1 Manpower costs during demonstration

$\begin{array}{ll}22 \text { Desiga cost } & (30 \% \text { of } 2.5) \\ 2.3 \text { Inspection cost } & (7 \% \text { or } 2.5) \\ 2.4 \text { Project management } & (10 \% \text { or } 2.5)\end{array}$

2.4 Project managemen

( $10 \%$ or 2.5$)$

2.5 Construction cout

$$
\begin{aligned}
& \text { 2.5.1 Building structure costs } \\
& \text { 2.5.2 Equipment costs } \\
& 2.5 .3 \text { Indireet ( } 29 \% \text { of } 2.5 .1 \% 2.5 .2) \\
& \text { Subtotal or } 2.5
\end{aligned}
$$

$(S \times 1000)$

Production Lacility construction costs

3.1 Design cost

( ALLOWANCE)

3.2 Inspection cost

3.3 Project management

3.4 Construction cost

( $7 \%$ or 3.4$)$

( $10 \%$ or 3.4$)$

$\begin{array}{ll}3.4 .1 & \text { Building structure } \\ 3.4 .2 & \text { Equipmeat costs } \\ 3.4 .3 & \text { Indirect }\end{array}$

Subtotal of 3.t

3.5 Construction management

3.6 Management Reserve

3.7 Contiagency

Subtotal 3.0

4.0

Operations

4.1 Conceptual design

4.2 Safery assurance

costs

( 2990 or $3.4 .1 \& 3.4 .2)$

( $17 \%$ o( 3.4)

( $10 \%$ o( 3.4)

( $25 \%$ of 3.1 inrough 3.5 )

ies (See Sect. 7)

4.t Preparation for operations $\quad(100 \%$ or 5.0$)$

4.5 Project Management

Subtotal +.0

( $10 \%$ of 4.1 inrough 4.4 )

Tolal Iaitial Cose (1.02.0.3.0 \& 4.0)

Operatiag and maintainence costs (Loading / Unloading Period)

S.1 Anoual operating costs

52 Anaual utility costs

5.3 Anoual material costs

S.4 Annual mainuinence costs

S.S Conciageacy

S.6 Subtotal 5.0

5.7 Total 20 year $O$ \& $M \cos 1$ ( 20 times Subtolal 5.0 )

( $25 \%$ of 5.1 shrough 5.4 )

Decontamination \& Decommissioning

ROM Life cyele costs (20 years operation)

$\begin{array}{ll}\text { so } & \text { so } \\ \text { so } & \text { so } \\ \text { so } & \text { so } \\ \text { so } & \text { so } \\ \text { so } & \text { so } \\ \text { so } & \text { so }\end{array}$

so

so

so

so

so

so

so

so

so

so

so

so

$\$ 3,000$

57.239

510.341

$\$ 3.500$

57.239

S10.31

575,397

54.768

523248

$5103,+13$

$\$ 17,684$

$510,3+1$

535.419

$\$ 187.437$

$\mathbf{5 7 5 . 3 9 7}$

54.768

$523.2+8$

$5103 .+13$

517.684

$510.3+1$

S35.54t

S188.062

52.812

51,874

$\$ 6.000$

S4. 736

S1.542

\$16,964

52.821

51.581

$\$ 6.000$

511.689

S2.239

$\$ 2+, 630$

5204.401

$\$ 212.692$

5240

53
5629

5629

S924

5947

54.736

S94.720

56.160

519

se고요

S924

도. 38

511.689

$\mathbf{2} 33.780$

520005

$\$ 46576$

$\$ 331.126$ 
Table 15-4. PLCC estimate summary for engineered facility (cost module P).

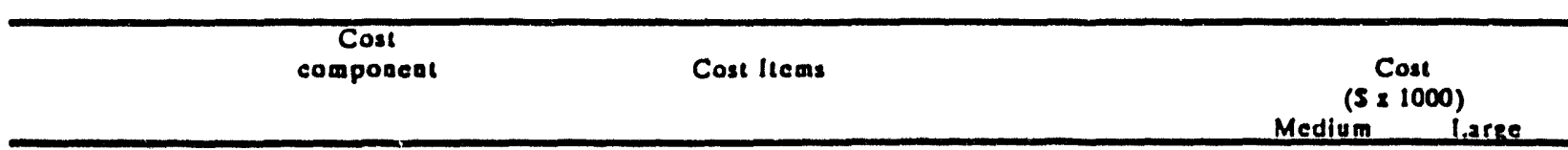

Studies and bench scale tesi cosis

1.1 Manpower costs during research

1.2 Equipment costs

1.3 Installation costs

1.t Project management before tille I ( $10 \%$ of 1.1 through 1.3)

1.5 Contingency

( $25 \%$ of 1.1 (hrough I.t)

Subroral 1.0

Demonsiration cosis

2.1 Manpower costs during demonstration

2 Design cost

2.3 Inspection cost

( $30 \%$ or 2.5$)$

2.4 Project management

$(790$ or 2.5$)$

2.5 Construction cosi

( $10 \%$ o( 2.5)

$$
\begin{aligned}
& \text { 2.5.1 Building structure costs } \\
& \text { 2.5.2 Equipment costs } \\
& \text { 2.5.3 Indirest ( } 29 \text { \% of 2.5.1 \& 2.5.2) }
\end{aligned}
$$

Subtotal of 2.5

2.8 Contingency

Subtotal 2.0

Production facility construction cosls

3.1 Design cost

32 Inspection cost

3.3 Project management

( ALLOIVANCE)

$(7 \%$ or 3.t)

( $10 \%$ or 3.4 )

3.t Construction cost

$$
\begin{array}{ll}
\text { 3.t.1 Building structure costs } \\
\text { 3.t.2 } & \text { Equipment cosis } \\
3 .+.3 & \text { Indired }
\end{array}
$$

( $29 \%$ of $3.4 .1 \& 3.4 .2$ )

Subtotal of 3.t

3.5 Construction management

3.6 Managemeni Reserve

( $17 \%$ of 3.4 )

( 1050 or 3.4 )

3.7 Contingency

( $25 \%$ of 3.1 through 3.5 )

Subtotal 3.0

Operations Budget Funded Activities (See Sect. 7)

t.1 Conceplual design (1.5\% of 3.0)

t.2 Salecy assurance (1\% or 3.0$)$

t.3 NEPA permitting (S6 Mill for EIS. SI Mill for EA)

t.4 Preporstion for operations

( $100 \%$ of 5.0 )

+.5 Projeet Management

( $10 \%$ of +.1 through 4.4 )

Subtotal 4.0

Tolal Initial Cost (1.02.0.3.0 \& t.0)

$\begin{array}{ll}S O & S O \\ 50 & S O \\ 50 & S O \\ 50 & S O \\ 50 & S O\end{array}$

Operatiag and maintsinence costs (Loading / Unloading Period)

5.1. Annual operating costs

5.2 Annual usility costs

5.3 Anaual material costs

5.t Annual maintainence costs

5.5 Contingency

S.6 Subtotal 5.0

( $25 \%$ of 5.1 through 5.4 )

5.7 Tolal 20 year O \& $M \operatorname{cost}$ (20 times Subioial 5.0)

$\$ 3,500$

$\$ 17.050$

524,358

S182.878

S5.9+1

$55+, 758$

$\$ 2+3.577$

$5+1.652$

$5+358$

582.534

$\$ 137,029$

56.555

$\$+.370$

56.000

$\$ 17.130$

$\$ 3.406$

$\$ 37,+61$

$5+74.490$

$56 .+40$

559

$\$ 6,089$

S1.114

$\$ 3 .+26$

$\$ 17.130$

$\$ 3+2,600$

570.505

5887,595
$\$ 10.000$

$5+6,702$

S66.717

$\$ 507.737$

59.451

S1 +9.985

S667.173

S114.087

566.717

5246.170

S1.197.566

$\$ 17,963$

$\$ 11.976$

56.000

S36.755

57269

$\$ 79.963$

51.277 .529

512.180

5156

515280

51.788

57.351

\$36.755

$\$ 735,100$

$\$ 134,887$

2.1\$7.516 
Table 15-5. PLCr estimate summary for engineered RCRA disposal facility (cost module Q).

\begin{tabular}{ccc}
\hline Cost & Cost ltems & Cost \\
composent & & $(S \times 1000)$ \\
Small
\end{tabular}

1.1 Manpower costs during researeh

1.2 Equipment costs

1.3 Installation costs

1.4 Project management before title I ( $10 \%$ of 1.1 through 1.3$)$

1.5 Contingenr.y

Subtotal 1.0

2.0 Demonstration costs

2.1 Manpower costs during demonstration

22 Desiga cost

2.3 Inspection cost

$(30 \%$ of 2.5$)$

2.4 Project management

( $7 \%$ of 2.5 )

2.5 Construction cost

$(10 \%$ o( 2.5$)$

$$
\begin{array}{ll}
2.5 .1 & \text { Building structure costs } \\
2.5 .2 & \text { Equipment costs }
\end{array}
$$

2.5 .3 Indirect ( 29 \% or 2.5 .1 \& 2.5.2)

Sublotal of 2.5

2.6 Construction management costs ( $17 \%$ or 2.5$)$

2.7 Management Reserve (10\% of 2.5 )

2.8 Contingency

Subtoral 2.0

Production facility construction coses

3.1 Desien cost

3.2 Inspection cost

3.3 Project management

( ALLOWANCE)

$\left(\begin{array}{l}7 \% \text { or } 3.4) \\ (10 \% \text { or } 3.4)\end{array}\right.$

3.t Consinuction cost

$\begin{array}{ll}3.4 .1 & \text { Building structure costs } \\ 3.4 .2 & \text { Equipment costs } \\ 3.4 .3 & \text { Indirect }\end{array}$

Subtotal of 3.t

3.5 Construction management

3.6 Management Reserve

3.7 Contingency

Subtotal 3.0

Operations

4.1 Concepiual design

\$2 Salety assurance

costs

( 2990 of $3.4 .1 \& 3.4 .2)$

( $17 \%$ of 3.4 )

( $10 \%$ or 3.4$)$

( $25 \%$ or 3.1 inrough 3.5 )

+. 3 NEPA permittin

Mill tor EIS. Si Mill (or EA)

(100\% of 5.0$)$

4 Project Management

Sublotal $\$ .0$

Total laitial $\operatorname{Cost}(1 \cdot 0.2 \cdot 0.3 .0 \& 4.0)$

( $10 \%$ of 4.1 (hrough 4.4 )

ies (See Sect. 7)

$(1.5 \%$ or 3.0$)$

( $1 \%$ or 3.0 )

Operating and maintainence costs (Losding / Unlonding Period)

5.1 Aunual operating costs

52 Anaual utility costs

S.3 Anaual material coses

S.4 Anaual maintainence costs

S.S Contiagency

( 2550 of 5.1 through 5.4 )

5.6 Subrotal 5.0

5.7 Total 20 year O \& iM cost (20 times Subtotal S.0)

Deconcamination \& Decommissioning

$\begin{array}{ll}\text { so } & \text { so } \\ \text { so } & \text { so } \\ \text { so } & \text { so } \\ \text { so } & \text { so } \\ \text { so } & \text { so } \\ \text { so } & \text { so }\end{array}$

so

so

so

so

so

so

so

so

so

so

so

so

so

so

so

so

so

SO

so

so

so

so

so

so

so

so

\begin{tabular}{|c|c|}
\hline $\begin{array}{r}\$ 3,000 \\
\$ 7,451 \\
\$ 10,644\end{array}$ & $\begin{array}{r}\$ 3.500 \\
\$ 7,451 \\
\mathbf{s 1 0 . 6 4 4}\end{array}$ \\
\hline $\begin{array}{r}S 77,523 \\
S 4.990 \\
\mathbf{S 3 . 9 2 9}\end{array}$ & $\begin{array}{r}577.523 \\
S 4.990 \\
S 23.929\end{array}$ \\
\hline 5106.442 & $5106 .+12$ \\
\hline s18202 & $\$ 18.202$ \\
\hline $510,64 t$ & 510.64 \\
\hline$\$ 36.435$ & 536.560 \\
\hline 5192818 & 5193.413 \\
\hline
\end{tabular}

so

$\$ 2.892$

51.928

$\$ 6,000$

S4.790

S1.561

$S 17,171$

52.902

51.934

56.000

S11.740

52258

$\mathbf{S 2 4 , 8 3 4}$

$\mathbf{S 2 0 9 , 9 8 9}$

\begin{tabular}{|c|c|}
\hline$\Omega 240$ & $\begin{array}{r}56.160 \\
516\end{array}$ \\
\hline 5622 & $\Omega 2+8$ \\
\hline 5968 & 5968 \\
\hline 5958 & 52.348 \\
\hline 54.790 & $\$ 11.740$ \\
\hline 595,800 & 5234.800 \\
\hline 532.003 & 546.576 \\
\hline 337.792 & 5499,653 \\
\hline
\end{tabular}

5218.27 
Table 15-6. PLCC estimate summary for engineered RCRA disposal facility (cost module Q).

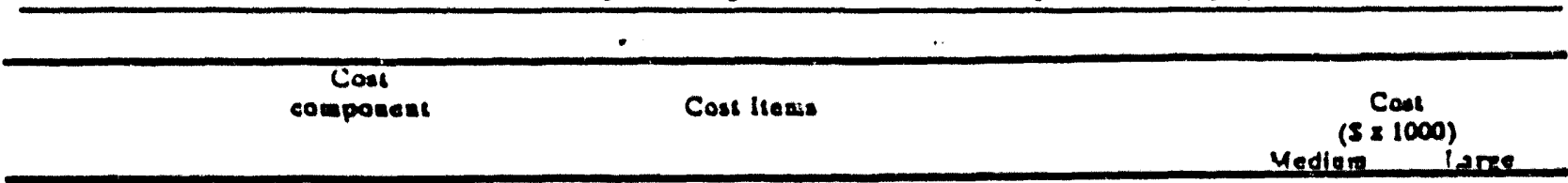

Sludies and bench seale test conts

1.1 Manponer costs dunag researen

12 Equipmeat cosls

1.3 lassillauon coss

i.t Project managemeal before litle I ( $10 \%$ of 1.1 throusa 1.3)

1.5 Coounzeacy

( $25 \%$ of 1.1 ubrough 1.4 )

Subcotal 1.0

$\begin{array}{ll}\text { so } & \text { so } \\ \text { so } & \text { so } \\ \text { so } & \text { so } \\ \text { so } & \text { so } \\ \text { so } & \text { so } \\ \text { so } & \text { so }\end{array}$

2.0 Desnosimuor costs

2.1 Magpower cosls dunaz de monsiration

22 Desiga cout

( $30 \%$ o( 25$)$

23 laspexuon cont

( 7 \% o( 2.5)

2.t Project manasersent

( $10 \%$ o( 25$)$

is Consunicuon cost

$$
\begin{array}{ll}
2.5 .1 & \text { Building structure costs } \\
\text { 2.S. Equipenent costs } &
\end{array}
$$$$
\text { 2.5.3 Indireet }
$$

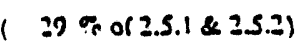

Subtotal of 2.5

2.6 Consirucion manaeement costs, $17 \sigma_{p}$ ol 2.5$)$

2.7 Madazement Reserve

$(10 \%$ or 2.5$)$

2.3 Contuneener

i $25 \%$ o( 2.1 throuen 2.7)

Sublotal 2.0

Production facility construction costs

3.1 Desiga cost

32 Inspecuor coss

3.3 Project managemert

3.t Construction coss

$$
\begin{array}{ll}
3.4 .1 & \text { Buildiag structure cosis } \\
3 .+2 & \text { Equipment cosis } \\
3 .+3 & \text { Indireet }
\end{array}
$$

Sublocal ol 3.4

3.5 Construction management

3.6 Magagement Reserve

3.7 Conciageacy

Subcolal 3.0

Operauons Budger

\$.1 Conceppual desiga

+2 Safery assurance

( ALLOWANCE)

( 790 o( 3.4)

( $10 \%$ o( 3.4 )

\section{so}

so

so

so

so

so

so

so

so

so

so

so

$\$ 3500$

53500
517506

s5.009

S187.004

56262

\$56221

S50.087

$5+2.765$

$\Omega 5.009$

S84.717

S4+8593

56.729

54.486

56.000

517209

53.+44

537.888

+.S Project Management

$$
(100 \% \text { o( } 5.0)
$$

Subiotal 4.0

Total Initial Cost (1.020.3.0\& +.0)

5486.481

Operaung and maintainenee costs (Losding / Untoading Penod)

S.1 Annual operaune cosus

5.I Annual utility cosss

5.3 Anaual macenal cosss

S.t Annual mainuinence cosls

5.5 Conuagency

S.6 Subtotal 5.0

5.7 Toul 20 vear $O \& M$ cost (20 times Subtotal 5.0 )

( $25 \%$ or 5.1 thre sh 5.4 )

Decoalamination \& Decommussioning

ROM Lile evele costs 120 vears nperalion 1
S6.440

559

50.089

S1.195

$53 .+16$

S17 29

$53+4.580$

s70.s0s

5901566
S1.300

$\$ 10.000$

$\$ 47.643$ 50.062

5517.737

59.876

S153,008

5680.621

5116.386

568062

$\mathbf{2 3 0 . 6 7 8}$

s1 21.452

51832

512215

56,000

536894

57343

sse.7t

$\$ 12.180$

Sis6

S15280

51.899

57.379

526.894

ST37.880

5134.857

$\$ .174 .993$ 


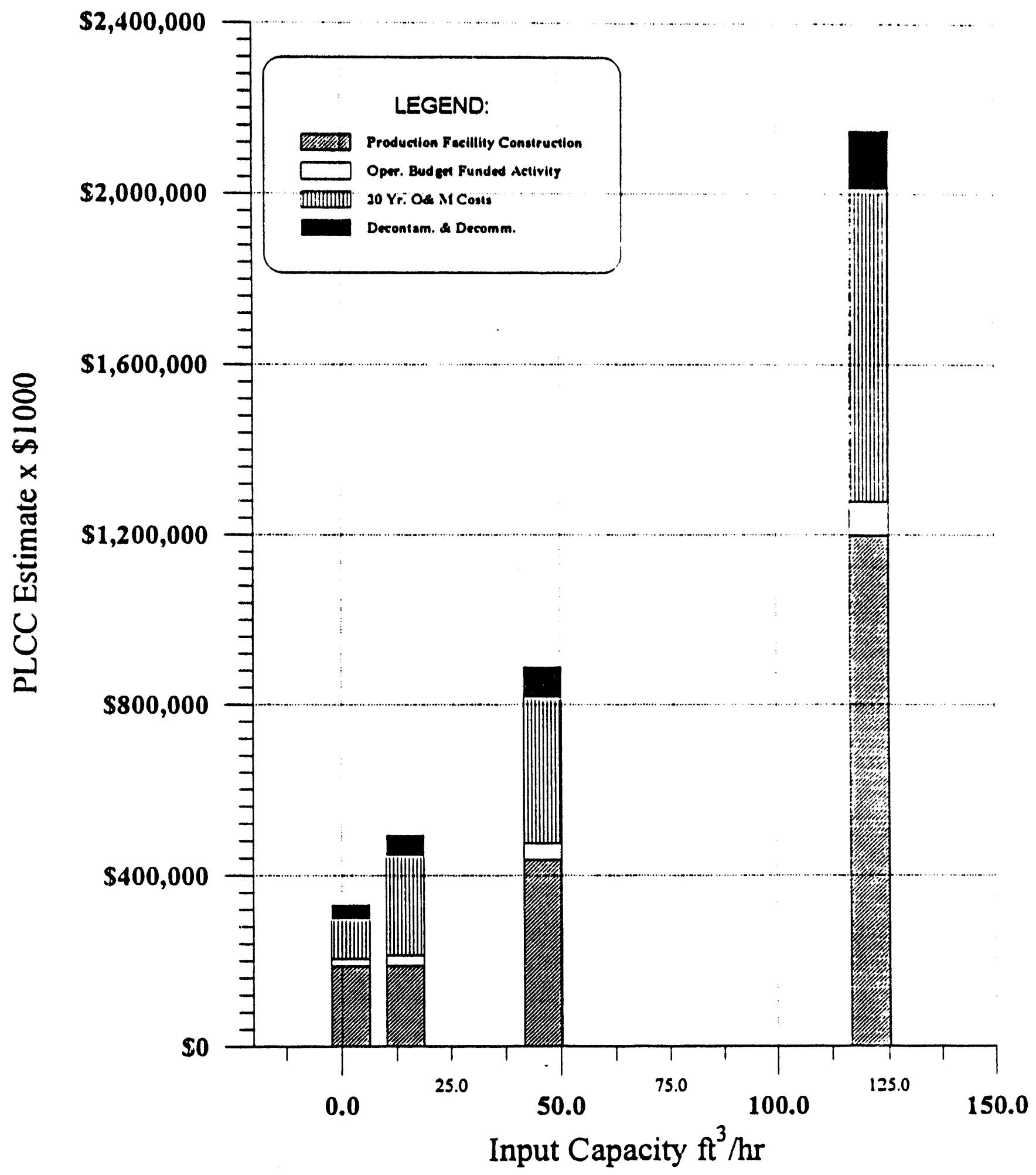

Figure 15-3. Cost versus capacity histogram for engineered disposal facility (cost module P). 


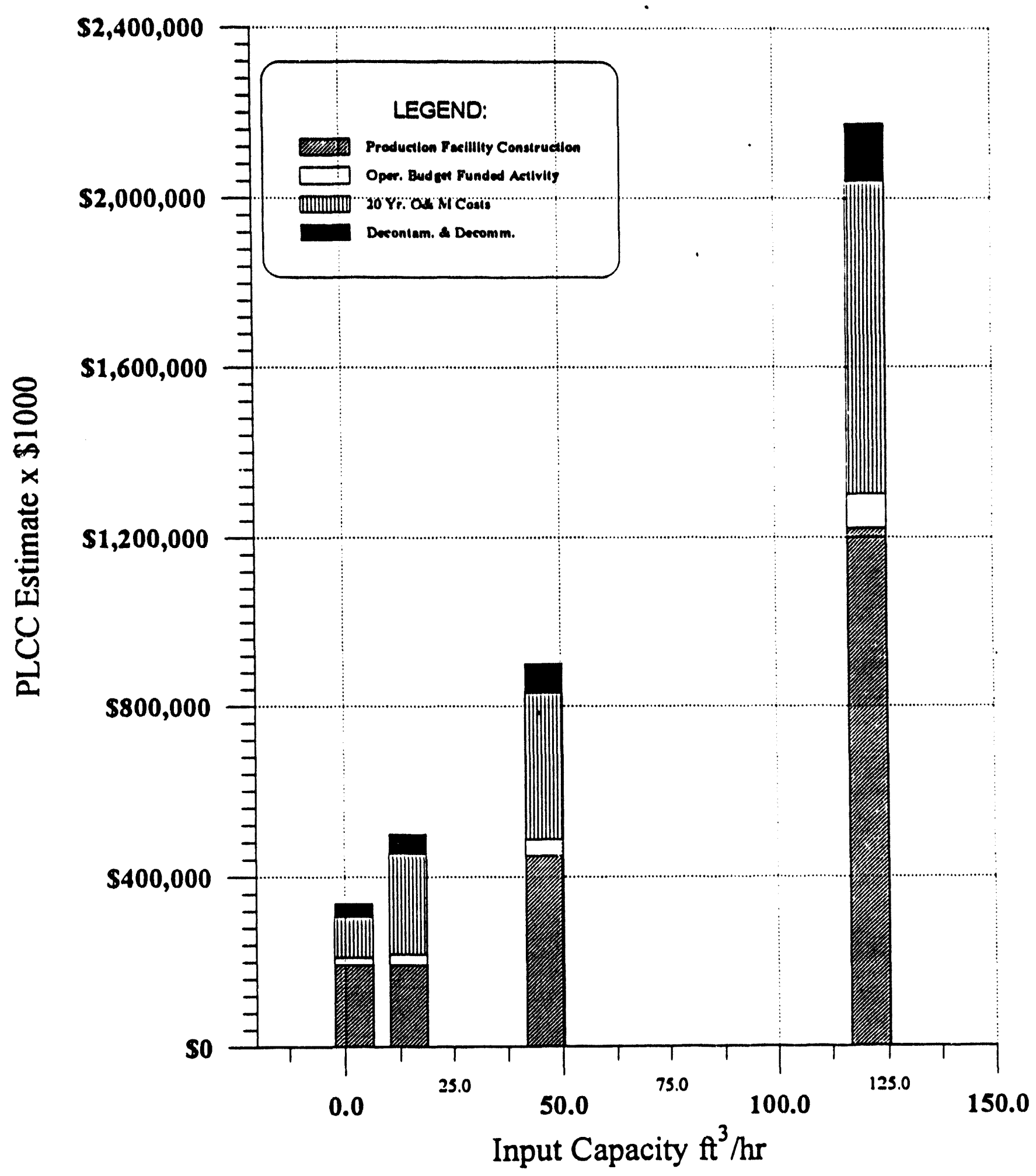

Figure 15-4. Cost versus capacity histogram for engineered disposal facility (cost module Q). 


\section{GTCC LLW INTERMEDIATE DEPTH DISPOSAL FACILITY (COST MODULE KK)}

\subsection{Basic Information}

The GTCC LLW intermediate depth disposal facility, shown in Figure 16-1, consists of surface structures where the waste is prepared for disposal, an access shaft, and mined disposal drifts. The facility should be used in conjunction with the disposal front-end support facility (cost module 0 ) given in Section 14, or as an addition to existing facilities where similar functions are already available. The intermediate depth facility assumes that the waste is already processed in packages which are suitable for the given disposal method. The unit operations that accomplish the general functions are shown in Figure 16-2.

\subsection{Technical Basis and Assumptions}

\subsubsection{Functional and Operational Description}

The work packages received from the disposal front-end support facility are transported to a hoist house via truck or railcar. A holding area is provided at the hoist house for lag storage. The hoist is sized according to maximum expected loads due to the waste packages and cargo elevators. The waste is loaded into a shielded transporter using an overhead bridge crane. The elevator moves the transporter via the main access shaft down to the subsurface operations gallery, where there is sufficient space for lag storage, until the waste is transported to its final location. At the operations gallery, a bridge crane is used to load and unload the waste from the shielded transporter and place it in the storage area. The shielded transporter is also used to move the waste to its final disposal location. At the disposal location, an overhead crane lifts the shield bell from the shielded transporter and unloads the container out of the shield bell. The crane then places the unloaded container in the disposal location.

Surface facilities include a waste receiving and ventilation house, support area, the hoist house, and support facilities including an emergency power generator for subsurface lighting and utilities. Subsurface features include the access shaft, operations gallery, and disposal drifts.

The waste is placed so that the exhaust shafts, which also serve as emergency exits, are not blocked until it is no longer necessary to use the tunnel beyond their location. Shield walls are erected at appropriate intervals after the waste canisters are placed in their final location, and the drifts are closed using a suitable backfill material. The site is assumed to have geologic characteristics such that the drifts will be drilled into stable rock and infiltration of any leaking material will be minimal. The monitor systems include sensors that detect leakage.

Closure consists of backfilling the drifts that are not already filled, backfilling the exhaust and access shafts, and decrmmissioning the lighting and utilities. Surface facilities are demolished and any remedial action deemed necessary is performed at the surface level. The hoist house is demolished after a specified monitoring period and the location of the access shaft is leveled, graded, and capped. Long-term monitoring includes testing the groundwater surface soil for any radiation effects and fencing off the disposal area for 300 years. 


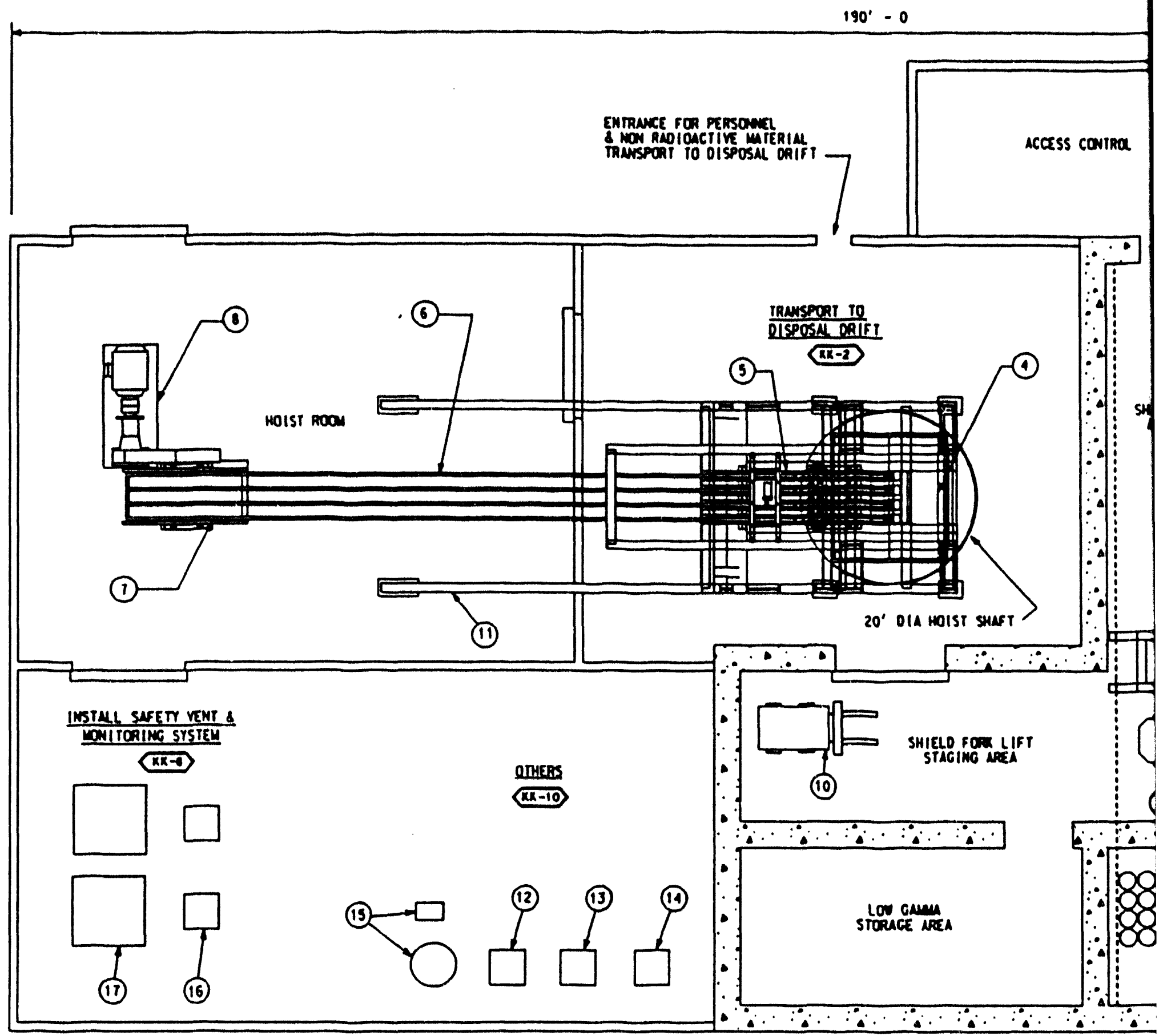

INTERMEDIATE DEPTH C
PLAN A

o4

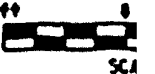

Figure 16-1. GTCC LLW intermediate depth disposal facility plan (cost module KK). 


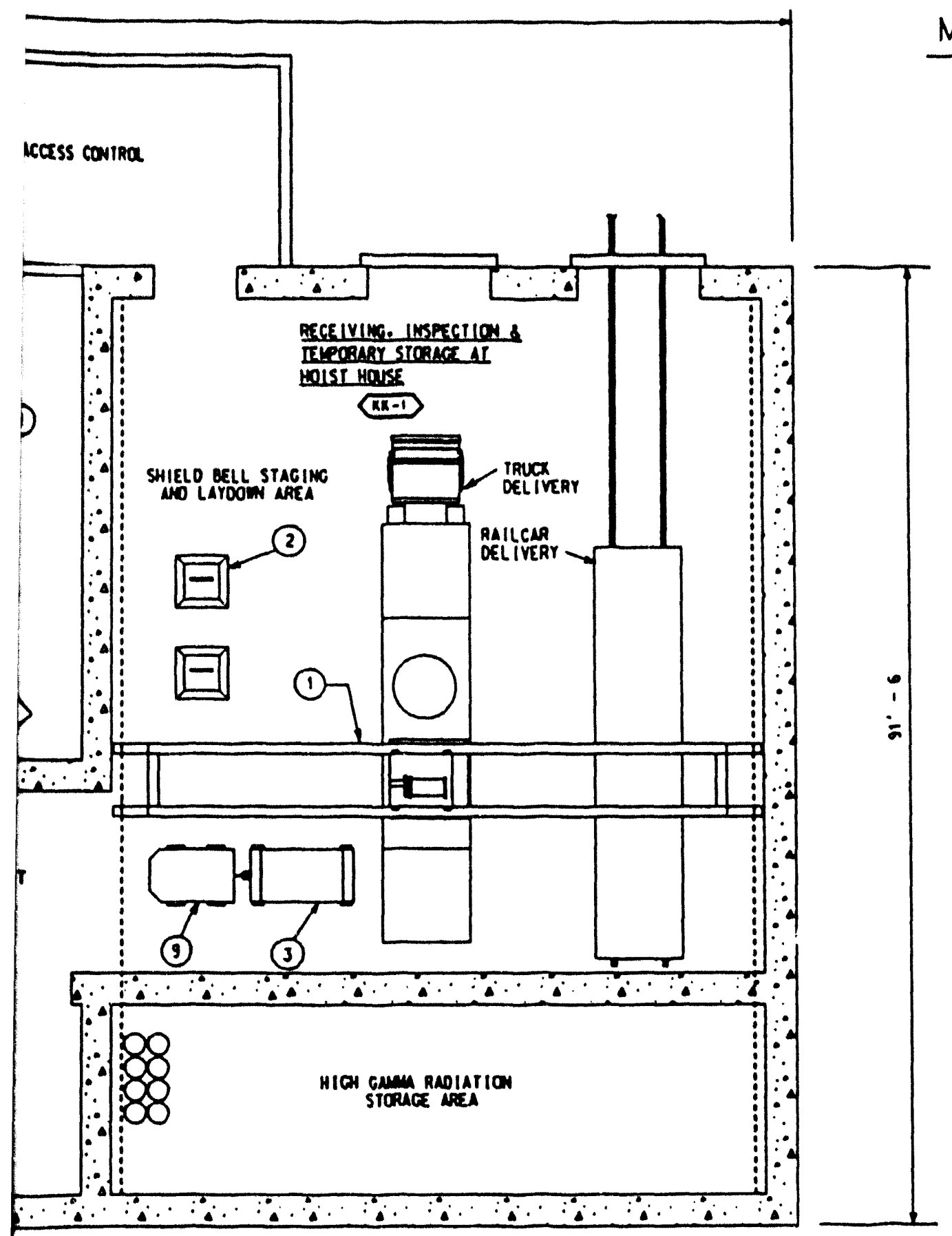

\section{MAJOR EQUIPMENT LIST}

(1) 30 rON BAIOCE CRANE WITH 10 rOW AUX.

(2) SHIELO BELL

(3) TRUASPORT CART

(4) min molst cace

(5) Holst sueaves (12' O1A.)

(6) HOIST hopes $11-3 / 4^{\circ}$ OlA. 1

(1) holst onem (12, O(A.)

(3) holst motor a cenaimo

(9) ror rauck

(10) SHIEloco fork LIFT

(11) hoIST FRANe

(12) instul alr pacxace

(13) Service alr pacrace

(14) BreathING aIR paCrace

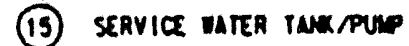

(16) Ventillation san

(17) alR hNOLINC UNIT

ATE DEPTH DISPOSAL (COST MODULE KK)

PLAN ABOVE GROUND

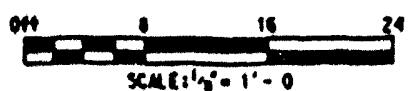

$\operatorname{sen} t_{1} \cos ^{\circ}=1 \cdot=0$ 


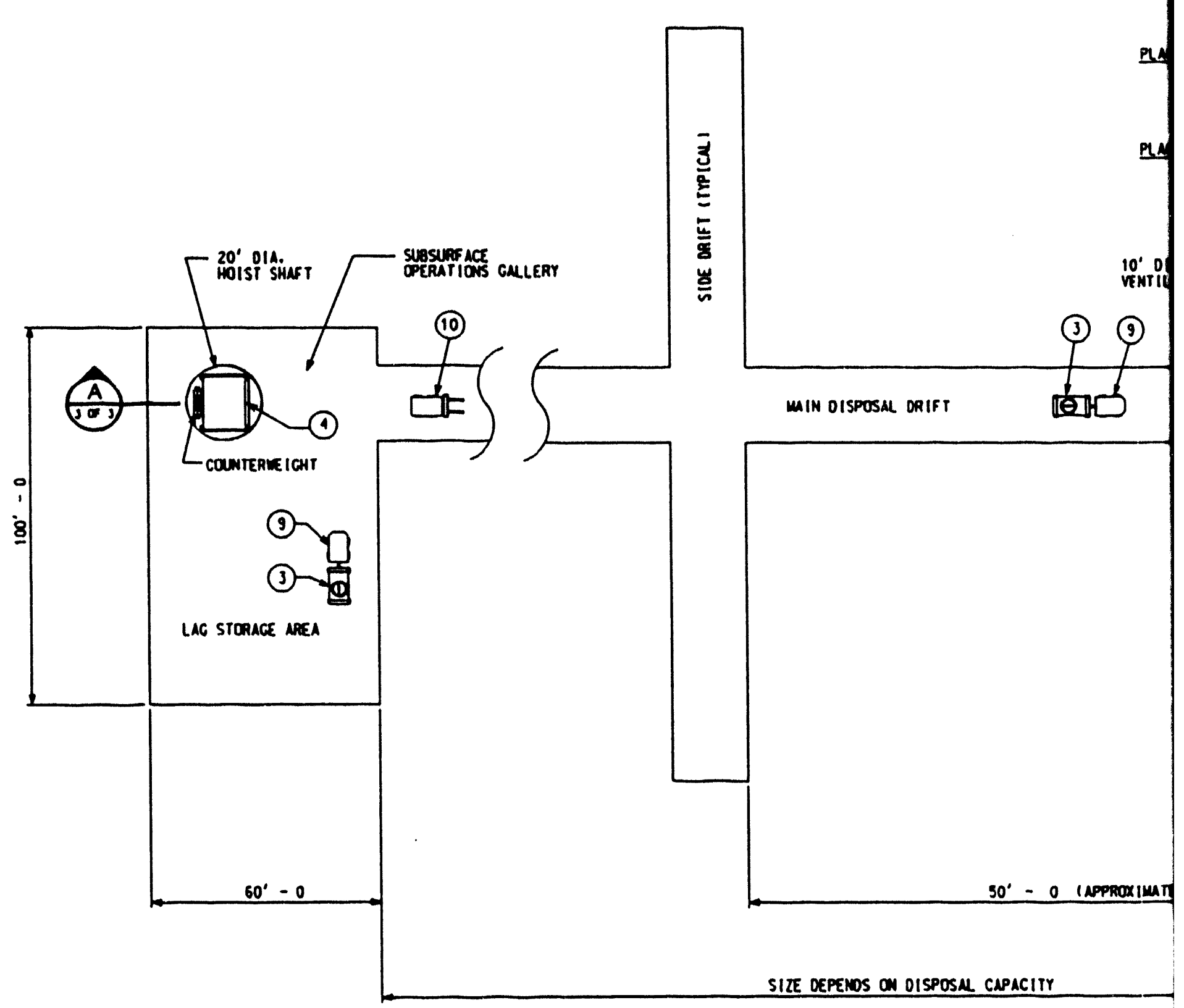

INTERMEDIATE DEPTH DISPOSAL ( COST MODULE KI PLAN BELOW GROUND

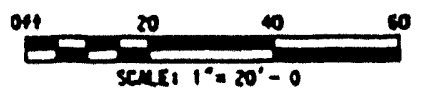

Figure 16-1. (continued). 


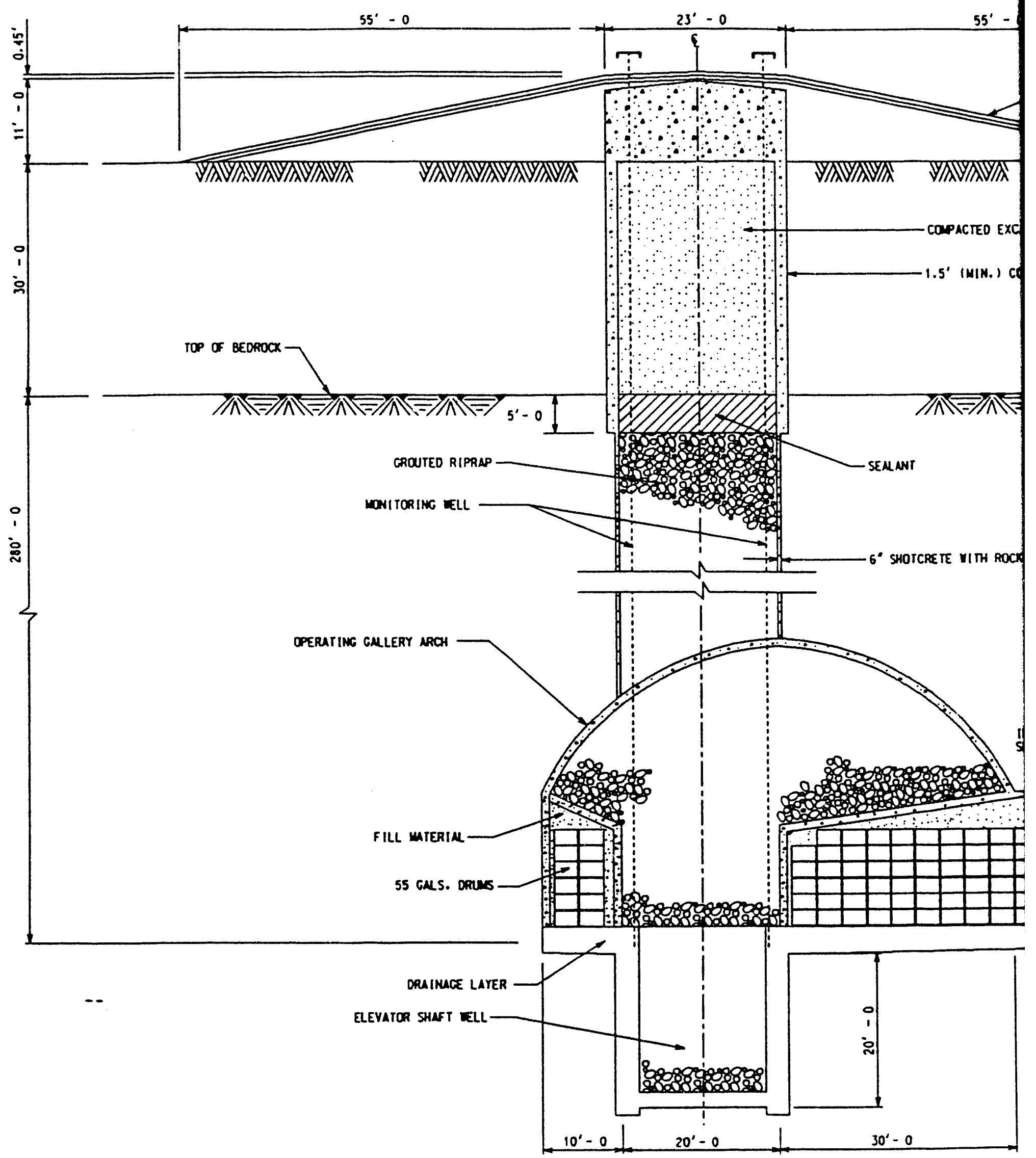

TYPICAL SECTION A AFTER CLOSURE

Figure 16-1. (continued).

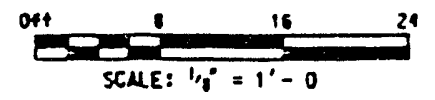




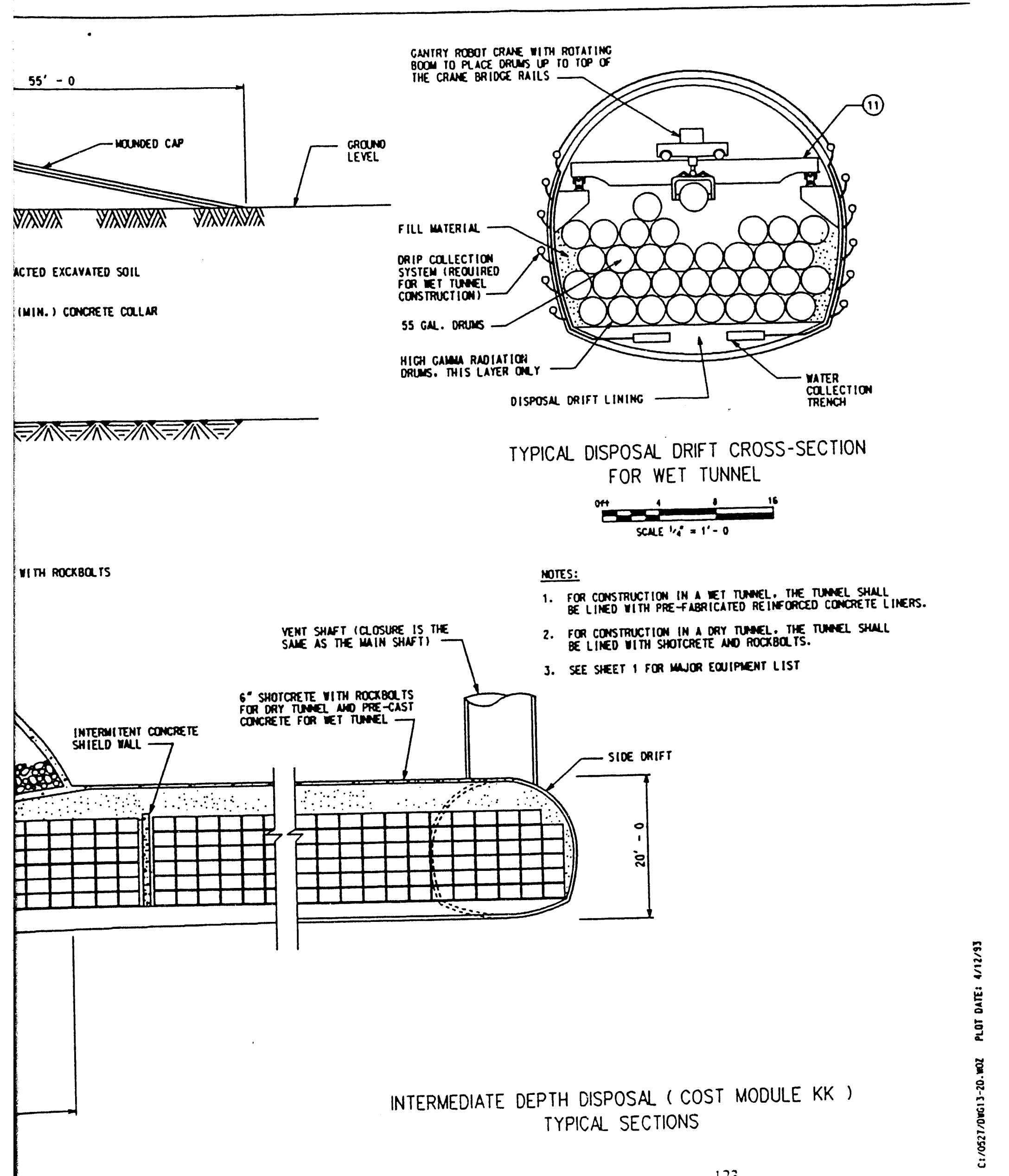




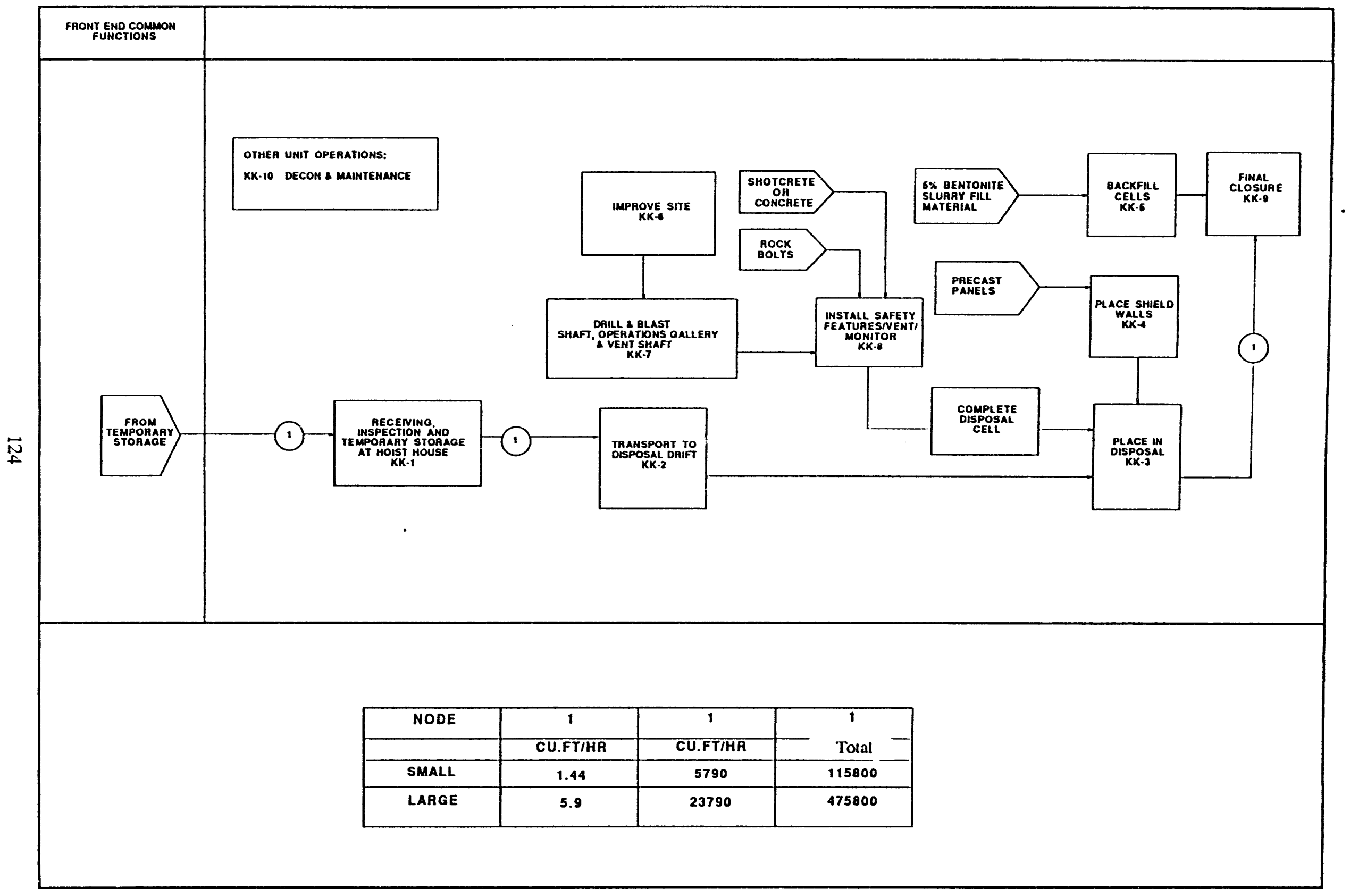

Figure 16-2. Process functional diagram for GTCC LLW intermediate depth waste disposal facility (cost module KK). 


\subsubsection{Facility Integration}

Input interfaces include waste drums delivered from the front-end facility (refer to cost module 0 ). O\&M consumables including rock bolts, shotcrete, and personal protective equipment must be purchased. The facility is intended for permanent disposal of the waste and designed for long-term maintenance and monitoring as described above. No facility output is anticipated.

\subsection{Cost Basis, Assumptions, and Assessments}

General cost basis and assumptions are given in Appendix A. Facility-specific items are discussed below:

- Rock where disposal drifts will be constructed is hard rock (such as granite or basalt) and is suitable for tunneling.

- Cost estimates based on using rock bolts and shotcrete for disposal drift linings. One ventilation/emergency exit shaft is assumed. Additional safety features such as concrete lining instead of shotcrete for wetter conditions and grouting any fissures or cracks in the rock are not included in the cost.

- Tunnels are not located in a groundwater region, major aquifer, or interbed containing perched water. Allowance is included in the estimate for moisture and minor water infiltration control system.

- Tunnels will be constructed using standard drill and blast methods.

- All material will be remotely handled and personnel will be adequately shielded using shielding and/or personal protective equipment.

- Waste arrives at surface facility in 55-gal. drums and is remotely placed into disposal drifts with no additional preparation.

- Precast concrete shield walls will be erected in the drifts every $200 \mathrm{ft}$ to protect personnel, and an overhead crane with an internal shield bell and shielded transporters will be used to move the drums to their disposal location.

- Backfill for tunnels after placement of waste drums will be concrete with $5 \%$ bentonite content. It will be delivered by truck from a mixing plant, lowered down the main access shaft and pumped through the drifts.

- $\quad$ Closure costs include demolition of surface facilities. The access shaft will he backfilled (the drifts already have been backfilled), and the area will be capped and fenced off after demolition.

- Estimated operating staff are shown in Table 16-1.

- Small and large facility capacities and unit costs are shown in Table 16-2.

\subsection{Cost Summaries}

Cost summaries for the GTCC LLW intermediate depth disposal facility cost modules are shown in Table 16-3. Histograms for cost vs. capacity are shown in Figure 16-3. 
Table 16-1. Estimated operating staff for GTCC LLW intermediate depth disposal facility (cost module KK).

Description

KK-1

KK-2

KK-3

$\mathrm{KK}-4$

KK-5

KK-6

KK-7

KK-8

KK-9

KK-10
Receiving, Inspection and Temporary Storage at Hoist House

Transport to Disposal 10

Drift

Place in Disposal Cell

Place Shield Walls

Backfill Cells

Improve Site

Drill \& Blast Access shaft, operations gallery and vent.

Install safety features/vent/monitor system

Final Closure

Others

Total

2

0

0
(FTE) Small

3

19

3

4

0

0

0

0

0

0

Table 16-2. Capacities and unit costs for GTCC LLW intermediate depth disposal facility (cost module KK).

\begin{tabular}{|c|c|c|c|c|c|c|}
\hline $\begin{array}{l}\text { Module } \\
\text { Coxde }\end{array}$ & $\begin{array}{c}\text { Module } \\
\text { Description } \\
\end{array}$ & Facility & $\begin{array}{l}\text { Life Cycle Cost } \\
(\$ \times 10(x))\end{array}$ & $\begin{array}{l}\text { Capacily } \\
\left(r^{3} / \mathrm{hr}\right)\end{array}$ & $\begin{array}{l}\text { Total Calpicity } \\
\left(n^{3} \times 1\right)(00)\end{array}$ & $\begin{array}{l}\text { Unit Cost } \\
\left(\$ / \mathrm{t}^{3}\right)\end{array}$ \\
\hline $\mathrm{K}$ & Intermediale Depth Disposal Facility & Snmall & $335, \sqrt{63}$ & $1 . \overline{44}$ & 116 & $\$ 2,8 \overline{93}$ \\
\hline$\overline{\mathbf{K}} \bar{K}$ & Intermediate Deptli Disposal Facility & Large & 583,2019 & 5.90 & 476 & $\$ 1,226$ \\
\hline
\end{tabular}


Table 16-3. PLCC estimate summary for GTCC LLW intermediate depth disposal facility (cost module $\mathrm{KK}$ ).

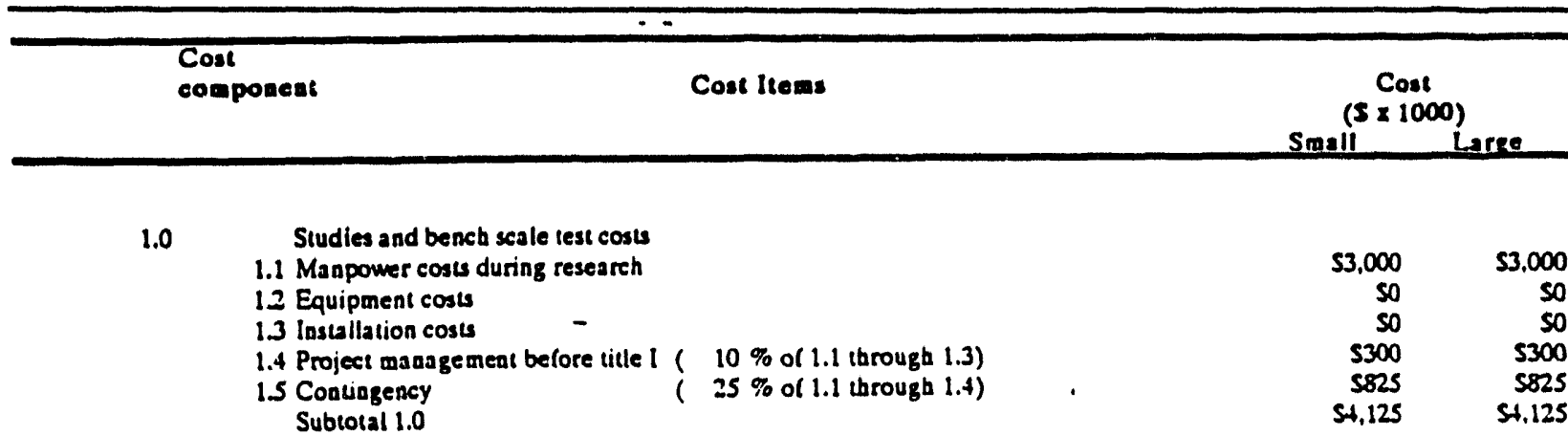

2.0 Demonstration costs

2.1 Manpower costs duriag demonstration

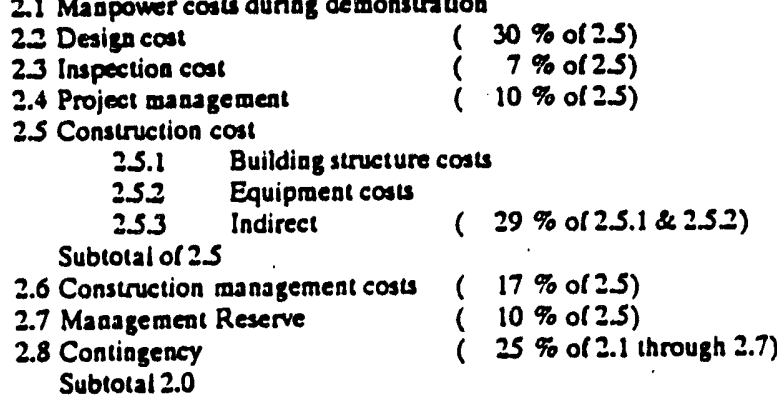

2.5 Construction cos:

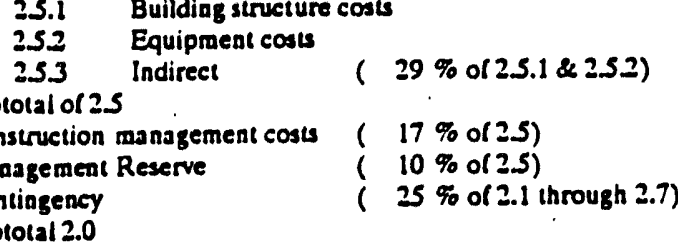

$\begin{array}{ll}S O & S O \\ S O & S O \\ S O & S O \\ S O & S O\end{array}$

$3.0 \quad$ Production Ecillty construction costs

32 Iaspection cost

( $18 \%$ o( 3.4$)$

3.3 Project managemeat

( $7 \%$ o(3.4)

( $10 \%$ o( 3.4)

3.4 Construction cost

3.4.1 Building structure costs

3.42 Equipmeat costs

3.43 lodirect

$(29 \%$ or $3.4 .1 \& 3.4 .2)$

Subtotal of 3.4

3.5 Construction managernent

( $17 \%$ or 3.4$)$

3.6 Management Reserve

( $10 \%$ of 3.4 )

3.7 Contingency

( $25 \%$ of 3.1 through 3.5 )

Subtotal 3.0

4.0

Operations Budget Funded Activities (See SecL. 7)

4.1 Conceptual desiga (1.5\% of 3.0 )

42 Safery assurance ( $10 \%$ of 3.0 )

4.3 NEPA permitting (S6 Mill for EIS, SI Mill for EA)

4.4 Preparation for operations (100\% of 5.0 )

45 Project Management (10\% of 4.1 through 4.4)

Subrotal 4.0

Toul Initial Cose $(1.02 .0 .3 .0 \& 4.0)$

Operating and maintaineoce costs

S.1 Annual operating costs

5.2 Anaual utility costs

53 Annual material costs

5.4 Anaual waintaineace costs

5.5 Coadingency

Subtotal 5.0

Total 20 year $O$ \& $M$ cost (20 times Subtotal 5.0)

52.240

$\$ 4,060$

580

5145

$\mathbf{S 3 , 9 3 9}$

51,601

$\$ 8,005$

$\mathbf{2 , 3 3 3}$

$\$ 11,005$

$\$ 27,313 \quad 567,550$

Decontsmination \& Decommissioning

$\$ 335,963$

$\$ \$ 83,209$ 


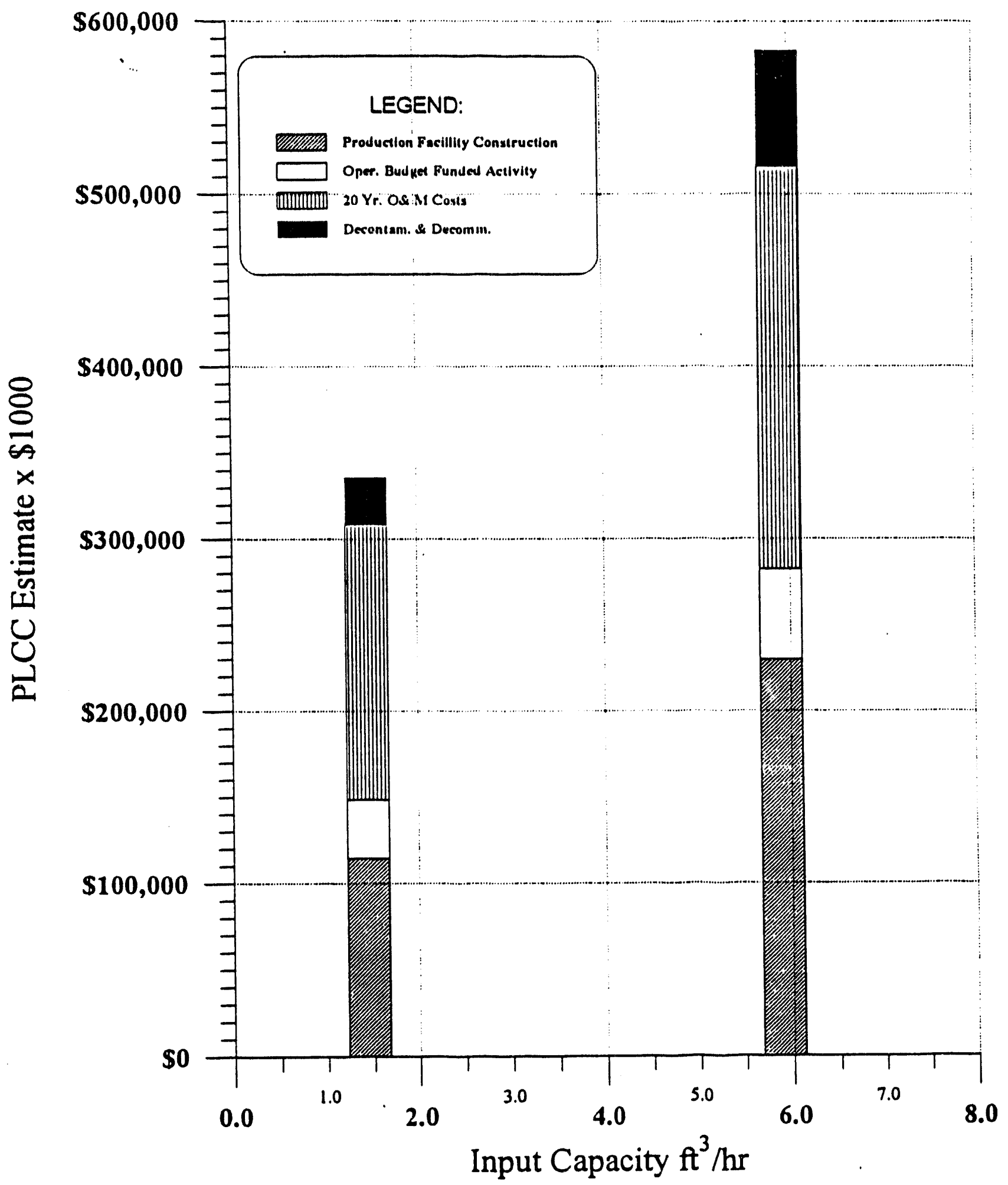

Figure 16-3. Cost versus capacity histogram for GTCC LLW intermediate depth disposal facility (cost module KK). 


\section{SHALLOW LAND DISPOSAL FACILITY (COST MODULE R)}

\subsection{Basic Information}

This facility consists of a shallow land trench disposal (without engineered features). The cost for a shallow land disposal consists of three components: front-end facility capital cost, disposal $O \& M$ cost, and site closure cost. Front-end facility capital cost is shown in Section 14 (cost module O), and should be added only if a new disposal facility is under consideration. DOE sites may use a disposal facility O\&M cost of $\$ 150 / \mathrm{ft}^{3}$, which is the cost at the Radioactive Waste Management Complex (RWMC) at the INEL.' For contact-handled waste, the INEL costs have ranged from $\$ 50 / \mathrm{ft}^{3}$ (for $100,000 \mathrm{ft}^{3} /$ year) to $\$ 150 / \mathrm{ft}^{3}$ (for $25,000 \mathrm{ft}^{3} /$ year). To obtain a PLCC estimate for shallow land disposal, the appropriate closure costs (estimated for cost modules $\mathrm{P}$ and $\mathrm{Q}$ ) have been added to the INEL disposal O\&M costs. The results are presented in Table 17-1. As an alternative, shallow land disposal costs can be estimated using rates from commercial disposal sites. Disposal fees at commercial sites include all of the three components. Figure 17-1 contains estimated disposal fees at four commercial disposal sites: Hanford, WA; Beatty, NV; Ward Valley, CA; and Barnwell, SC.

\subsection{Technical Basis and Assumptions}

Since shallow land trench disposal units are commonly used by both the DOE and the commercial nuclear industry, a preconceptual design of disposal units to develop PLCC estimates was not necessary. The technical basis for front-end facilities is given in Section 14. Basis for closure costs are theisame as those given in Section 15.

\subsection{Cost Bases, Assumptions, and Assessments}

The cost data outlined in this sec a do not include surcharges that may have to be added to the standard unit rates to account for increased Curie content (remote-handled waste), nonstandard packaging, excessive weight, and other parameters of the waste that requires special handling.

The graph shown in Figure 17-1 illustrates costs for four commercial sites, including initial capital costs, O\&M, and closure. Of the four facilities shown, Barnwell and Washington Nuclear Center are currently the only operating facilities. Costs for Barnwell include a \$200 access fee. Costs for Ward Valley and Butte Nebraska are based upon telephone conversations with U.S. Ecology representatives. Costs shown in Figure 17-1 are approximate, and judgement must be used in applying these costs.

Contact and remote-handled waste disposal costs are based on the following assumptions:

1. Contact-handled waste is enclosed in trailer shipments consisting of 40 drums in each trailer.

2. No biological or special nuclear material is contained in contact- or remote-handled waste.

3. All contact- and remote-handled waste is shipped in drums with a weight less than $5,000 \mathrm{lb} /$ drum.

f. Based on telephone conversation with Darris Bright of EG\&G. 
Table 17.1. Shallow land disposal closure cost versus capacity (cost module R).

\begin{tabular}{|c|c|c|c|c|c|c|}
\hline Module Code & Module Description & Facility & $\begin{array}{l}\text { Life Cycle } \\
\text { Cout } \\
(\$ \times 1000)\end{array}$ & $\begin{array}{l}\text { Capacity } \\
\left(\mathrm{It}^{3} \mathrm{mr}\right)\end{array}$ & $\begin{array}{c}\text { Total Capacity } \\
\left(\mathbb{1}^{3} \times 1000\right)\end{array}$ & $\begin{array}{l}\text { Unit Coet } \\
\left(\mathrm{s}^{\mathrm{m}} \mathrm{t}^{3}\right)\end{array}$ \\
\hline$R-(D O E)$ & Shallow Dispoeal of Contact Handled & Small & 150,958 & 6.00 & 500 & $\$ 312$ \\
\hline $\mathrm{R}-(\mathrm{DOE})$ & Shallow Dispoeal of Contact Handled & Large & 165,312 & 25.00 & 2000 & $\$ 82$ \\
\hline$R-$ (Commercial) & Shallow Disposal of Remote Handled & Small & 42,629 & 0.51 & 40 & $\$ 1,066$ \\
\hline$R-($ Commercial) & Shallow Dispoeal of Conlact Handled (1) & Large & & & & $\$ 81$ \\
\hline $\mathbf{R}-$ (Commercial) & Shallow Disposal of Remote Handied & Large & & & & $\$ 310$ \\
\hline
\end{tabular}

4. The curie content in each of the contact-handled shipments is less than 5 curies.

5. Contact- and remote-handled waste shipments do not contain tritium or Carbon 14.

6. $2.4 \%$ of the total cost is allowed for contact- and remote-handled waste for Barnwell only.

7. Decontamination allowance is $\$ 1,000$ per shipment for contact- and remote-handled waste.

8. All contact-handled shipments contain Class A waste.

9. When the generator is outside the compact region, an access fee is assessed. The access fee (when applicable) is shown separately on the graph.

10. Curie content of the remote-handled shipment is less than $\mathbf{5 0}$ curies.

11. Cask shipments contain seven drums or $50 \mathrm{ft}^{3}$ per shipment for remote-handled waste.

12. Container surface dose rates for remote-handled waste is less than $10 \mathrm{R} /$ hour.

13. Casks remain on trailers during unloading.

14. Nebraska and California rates are based on average rates for contact- and remote-handled waste. 
DISPOSAL COST (N/CU.FT.)

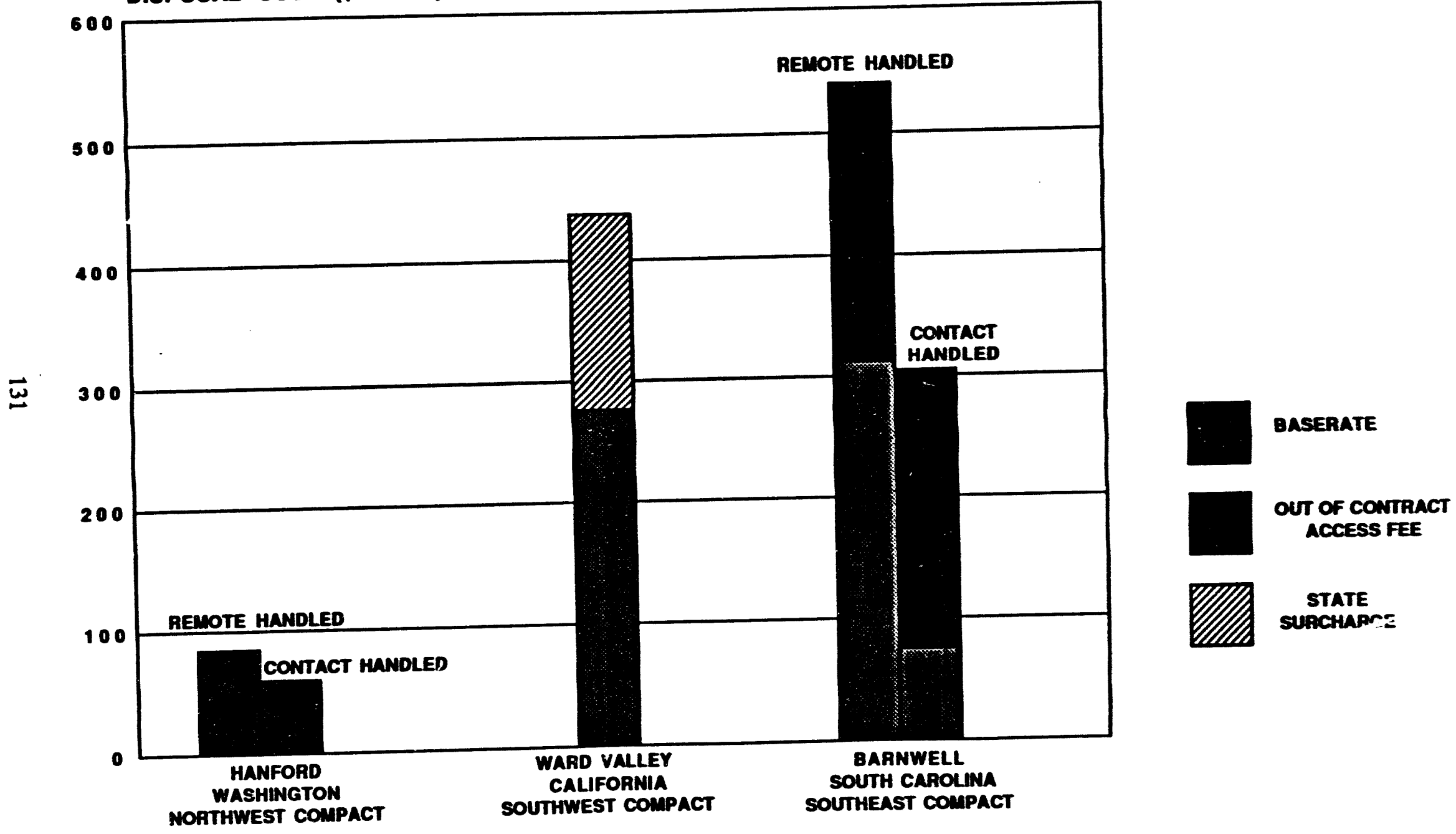

Figure 17-1. Cost comparison of commercial waste disposal facilities. 


\section{SCENARIO COSTING PROCEDURE}

This section presents guidelines to develop PLCC estimates for waste management scenarios.

\subsection{Waste Management Scenarios}

A waste management scenario is a case study of the TSD facilities and activities needed for cradle-to-grave handling of a given waste. A typical scenario may consist of the following elements:

- Generated (or stored) waste from Site 1 is shipped to Site 2 where it will be treated at a treatment facility to produce a stabilized waste form.

- Treated waste is transferred to Site $\mathbf{3}$ for interim storage.

- After the interim storage period, the waste is shipped to Site $\mathbf{4}$ for final disposal.

The report presents PLCC estimates, which are referred to as cost modules, for each TSD facility. These cost modules allow analyses of two distinctive types of waste management scenarios:

- Augmented facilities: The addition of treatment, storage, and disposal capabilities to existing waste management facilities : where some or all of the front-end/back-end handling and partial treatment functions are already in place.

- Stand-alone facilities: Scenarios that require new facilities to manage waste from cradle to grave.

\subsection{Cost Modules and Unit Operations}

Each discrete TSD facility is referred to as a cost module. There are a total of 16 cost modules (see list in Table 18-1) that c Juld be potentially used for management of GTCC LLW. As shown, seven treatment cost modules are provided for remotely handled waste such as GTCC LLW. Cost modules for storage also cover remote-handled waste. The disposal cost modules can be sued for LLW, MLLW, alpha-LLW/MLLW, and GTCC LLW.

Each facility is broken down into separate subfunctions, referred to as unit operations. Unit operations assume inclusion of all buildings, equipment, and accessories needed to accomplish the given subfunction.

\subsection{Scenario Costing Options}

PLCC estimates in this report can be used to develop costs for waste managemeni scenarios by two different methods: modular or cost component method. 
Table 18-1. WMFCI cost modules.

\section{Cost Module Desimation}

BB

$\mathrm{CC}$

DD

EE

FF

GG

HH
Description

Receiving preparation and shipping facility

Incineration

Metal melting

Shredding \& compaction

Solidification

Vitrification

Wet-air oxidation

\section{Application}

Treatment front- and back-end functions such as truck loading and unloading, staging and surge storage of incoming and outgoing waste, waste container assay and inspection for radiological and physical properties, sorting, discarded container handling, and special waste processing and packaging.

Incineration of remote-handled combustible and semicombustible solids, organic liquids, and sludge. The ash is converted into a solidified waste form.

Melting of remote-handled metals including steel, copper, aluminum, and lead. A significant portion of the radioactivity is precipitated into a slag waste so that most of the GTCC LLW metal waste can be disposed of as LLW. The high activity slag is mixed with a grout to rooduce a macro-encapsulated waste form.

Shredding and compaction of remote-handled combustible, semicombustible, and noncombustible solids. The product is volume reduced by supercompaction, placed in 80-gal drums, and capped with a grouk mixture to form a macro-encapsulated waste form.

Solidification and macro-encapsulation of remotehandled combustible, semicombustible and noncombustible solids. The treated waste has a solidified or macro-encapsulated waste form.

Vitrification of remote-handled semicombustible and noncombustible solids. The treated waste has a leach resistant, high integrity (rock, ceramic or glass) wasie form.

Oxidation of combustibles waste and converting the resultant concentrated liquid waste into a solidified waste form for loading/shipping. 
Table 18-1. (continued).

$\begin{array}{cl}\begin{array}{c}\text { Cost Module } \\ \text { Designation }\end{array} & \text { Description } \\ \text { II } & \begin{array}{l}\text { Metal sizing and } \\ \text { decontamination }\end{array}\end{array}$

J

KK Intermediate depth

LL Administration support

MM

O Disposal front-end

$\mathbf{P}$

Q

$\mathbf{R}$ disposal facility support facilities

HLW/GTCC LLW geologic repository

Silo storage

Engineered disposal RCRA compliance not required

Engineered disposal RCRA compliance required

LLW Shallow Land Lisposal

Enclosed vault storage
Application

Removal of entrained or surface contamination from metals with the objective of reducing them from GTCC LLW to LLW, thus allowing disposal in a shallow land disposal facility. The liquid and sludge waste from the facility is mixed with a binder to produce a solidified waste form. The decontaminated metal is compacted and filled with grout to form a macro-encapsulated product.

Disposal of GTCC LLW in an expanded wing of a HLW deep geological repository similar to the Yucca Mountain repository.

Disposal of GTCC LLW in intermediate depth $(300 \mathrm{ft})$ disposal unit.

Administration and common support functions, such as office, analytical laboratory, security, and environmental compliance functions that may be added to a GTCC LLW treatment facility.

Storage of GTCC LLW containers in aboveground silos located in a yard. The silos are watertight and do not require an enclosure. All operations are accomplished outdoors.

Unloading, receiving, and inspection of incoming waste containers and transport of containers to disposal facilities.

Packaging of radioactive waste containers into concrete canisters for disposal in above-ground earth-mounded concrete cells.

Packaging of radioactive containers into concrete canisters for disposal in above-ground earthmounded concrete cells equipped with RCRA mandated double liner and leachate collection system.

Disposal of LLW in shallow land trenches.

Storage of GTCC LLW containers in concrete vaults. The storage vaults are covered by a metal building enclosure. All operations are accomplished indoors. 
- Modular method: This method is used when the required facilities of a given scenario are compatible with those given in this report. The user simply determines which waste management facilities are needed, the capacity required for each facility, and transportation volumes and distances. Based on this information, the user calculates the total waste management costs following the procedure in Section 18.5.

- Cost component method: PLCC estimate for each facility comprises six cost components (see Appendix A). The cost component wethod should be used if the reader has access to an updated cost data on a given cost component. The reader may simply replace the updated costs in the appropriate table and calculate the new PLCC estimate by adding the six components. Once modified PLCC estimate is determined, the cost for the overall scenario is calculated in the same manner as the modular method.

\subsection{Information Required to Cost a Scenario}

To use either the modular or the cost component method, the following items must be known to the user:

1. Waste category: The user must be knowledgeable about radioactive waste categories is defined in DOE orders (e.g., 5820.2A) and NRC's 10 CFR 61 regulation, since the waste must be classified into one of the following general categories:

a. GTCC-LLW or DOE equivalent: GTCC LLW is commercially generated waste generally having a radionuclide concentration above the Class C LLW concentration limits given in the NRC regulation $10 \mathrm{CFR}$ 61. This waste is deemed to be unsuitable for disposal in shallow disposal facilities. The DOE equivalent waste has similar properties. Generally, both waste types have high gamma radiation and require remote handling and processing techniques.

b. LLW or MLLW: Wastes generated from nuclear reactor operation or nuclear research. Defense related LLW or MLLW usually has a transuranic concentration below $10 \mathrm{nCi} / \mathrm{g}$. MLLW is the same as LLW with the exception that it is subject to control under RCRA.

2: Waste treatment category: The user must have sufficient knowledge about the waste properties to select one of the seven treatment facilities described in this report. Various waste categories are described in Appendix A.

3. Input waste flow rate(s): The user must know the weight of the waste to be treated. Input waste is converted to $\mathrm{lb} /$ hour by dividing the total weight by 80,640 hours for a 20 -year life cycle. The 80,640 hours is the total processing hours based on 24 hours per day, 240 days per year, for 20 years at $70 \%$ availability.

4. Facility locations and transportation distances: The user must know which DOE site(s) will house the facilities and determine whether the facilities will be a stand-alone or augmented type. 


\subsection{Scenario Costing Procedure}

The scenario costing procedure (schematically shown in Figure 1-3) allows the user to develop the overall cost of a given scenario by following seven steps: (a) define scenarios, (b) define parameters, (c) develop treatment costs, (d) develop storage costs, (e) develop disposal costs, (f) develop transportation costs, and ( $g$ ) develop PLCC estimates. Each of these seven steps are described below.

\subsubsection{Define Scenarios}

The user must develop a strategy for cradle-to-grave management of the given waste stream by establishing the information listed below (see Figure 1-3 for a block diagram of a sample scenario).

- Waste source and location: Define waste streams, characteristics, and location where the waste is generated or stored.

- Treatment facility types and location: Define types and location of treatment facilities needed for each waste type.

- Interim storage period and location: Define types and location of interim storage facilities needed for each waste.

- Disposal type and location: Define types and location of disposal facilities needed for each waste.

- For each treatment, storage, and disposal facility, the user must determine whether the facilities will be stand alone or augmented to an existing operation that has common support functions.

\subsubsection{Define Parameters}

Parameters required for each scenario include the following:

- Treatment facility input waste feed rates: The basic requirements for the scenario are input waste feed rates. The total weight of the input waste (in pounds) is then established for each type of facility. The total weight must be divided by 80,640 hours to establish facility capacity in $\mathrm{lb} / \mathrm{hour}$.

- Treatment facility output waste flow rates: Output (treated) waste flow rates for each type of treatment facility should be determined in $\mathrm{ft}^{3}$ /hour. The treatment facility input waste rate (lb/hour) is multiplied by the output waste multiplication weight factor (see Table 18-2) to obtain the output waste mass flow rate (lb/hour). Then, the output flow rate is divided by the treated waste density to get waste volumetric flow raie ( ${ }^{r \cdot 3} /$ hour). Table 18-2.

- Storage facility input/output waste flow rates: Input waste flow rate is determined based on the scenario and is generally equal to the waste output from the treatment facilities. Waste output rate is also dependent on the scenario and is generally the same as the input rate, but can be adjusted to suit other requirements of the scenario. Flow rates should be developed in $\mathrm{ft}^{3}$ hour. 
Table 18-2. Waste treatment factors.

\begin{tabular}{|c|c|c|}
\hline Treatment Facility & $\begin{array}{l}\text { Output waste } \\
\text { conversion weight } \\
\text { factor }\end{array}$ & $\begin{array}{c}\text { Treated waste } \\
\text { density } \\
\left(1 \mathrm{~b} / \mathrm{ft}^{3}\right)\end{array}$ \\
\hline $\begin{array}{l}\text { Incineration } \\
\text { Solidified Waste }\end{array}$ & 0.493 & 112 \\
\hline $\begin{array}{l}\text { Metal Melting/Recovery } \\
\text { Metals } \\
\text { Solidified Waste } \\
\text { Slag }\end{array}$ & $\begin{array}{l}1.000 \\
0.306\end{array}$ & $\begin{array}{l}\text { (a) } \\
112 \\
172\end{array}$ \\
\hline $\begin{array}{c}\text { Shredding/Compaction } \\
\text { Compacted Waste } \\
\text { Solidified Waste }\end{array}$ & $\begin{array}{l}1.142 \\
0.209\end{array}$ & $\begin{array}{c}10-70 \\
112\end{array}$ \\
\hline $\begin{array}{l}\text { Solidification } \\
\text { Solidified Waste }\end{array}$ & 2.963 & 112 \\
\hline $\begin{array}{l}\text { Vitrification Waste } \\
\text { Vitreous Waste } \\
\text { Solidified Waste }\end{array}$ & $\begin{array}{l}0.958 \\
0.224\end{array}$ & $\begin{array}{l}187 \\
112\end{array}$ \\
\hline $\begin{array}{l}\text { Wet Air Oxidation } \\
\text { Solidified Waste }\end{array}$ & - & - \\
\hline $\begin{array}{l}\text { Metal Sizing \& } \\
\text { Decontamination } \\
\text { Solidified Waste } \\
\text { Macro-encapsulated } \\
\text { Metal Waste }\end{array}$ & $\begin{array}{l}- \\
-\end{array}$ & $\begin{array}{l}- \\
-\end{array}$ \\
\hline
\end{tabular}

(a) Same as the absolute density of the metal 
- Disposal facility input waste flow rates: Input waste flow rate is determined based on the scenario and should be generally the same as the waste output from the treatment facilities. Waste output rate from storage facilities must also be considered. Flow rates should be developed in $\mathrm{ft}^{3} /$ hour.

- Transportation distances: Transportation distances (in miles) should be calculated for the TSD facility incoming wastes.

Once the parameters are established for the various facilities in the scenario, the user should proceed with developing costs as described in Sections 18.5.3 through 18.5.7. Summary cost versus capacity tables for all treatment, storage, and disposal cost modules are provided in Tables 18-3, 18-4, and 18-5. These tables may be referred to in the following sections on developing PLCC estimates for TSD facilities.

\subsubsection{Develop Treatment Costs}

Treatment facility costs consist of three facility categories: administration support; receiving, preparation, and shipping; and treatment facilities. If the desired treatment facility is an addition to an existing facility, then only the cost for the treatment facility must be developed. However, if the facility is being added to a new location, then costs for the administration support, and receiving, preparation, and shipping functions must also be included.

Once the type of facilities have been established, the user can obtain PLCC estimates by selecting one of the cost modules that is closest to the required capacity from the cost modules presented in Table 18-3.

\subsubsection{Develop Storage Costs}

Once the type of facilities have been established, the user can obtain PLCC estimates by selecting one of the cost modules that is closest to the required capacity from the cost modules presented in Table 18-4.

\subsubsection{Develop Disposal Cost}

Disposal costs consist of two categories: front-end support and disposal facilities. The procedure used to determine disposal costs is the same one used to determined the treatment cost. Use Table $18-5$ to obtain cost and capacity information.

\subsubsection{Develop Transportation Costs}

Transportation costs for LLW, assuming that unshielded trucks are used, are calculated by multiplying the below-listed factors by the one-way distance (in miles) times the volume of the waste (in cubic feet) to be shipped. The variable and fixed transportaticn cost factors listed below are based on shipping $\mathbf{4 0}$ drums in each truck:

$\therefore \quad$ Up to 30 miles: $\$ 2.05 \times 10^{-2} / \mathrm{ft}^{3}$ per mile $(+\$ 2,480$ per shipment)

- $\quad 30$ to 200 miles: $\$ 1.72 \times 10^{-2} / \mathrm{ft}^{3}$ per mile (+ $\$ 2,480$ per shipment)

- Over 200 miles: $\$ 1.3 \times 10^{-2} / \mathrm{ft}^{3}$ per mile ( $\$ 2,480$ per shipment). 
Table 18-3. Summary cost versus capacity for treatment facilities.

\begin{tabular}{|c|c|c|c|c|c|c|}
\hline $\begin{array}{l}\text { Moxdule } \\
\text { Code }\end{array}$ & $\begin{array}{l}\text { Cost Module } \\
\text { Description }\end{array}$ & Facility & $\begin{array}{c}\text { Life Cycle } \\
\text { Cost } \\
(\$ \times 1000)\end{array}$ & $\begin{array}{c}\text { Total } \\
\text { Calpicity } \\
\text { (IIIs X10(X)) }\end{array}$ & $\begin{array}{l}\text { Cilpucity } \\
\text { (liss/lur) }\end{array}$ & $\begin{array}{l}\text { Unit Cosit } \\
(\$ / 11)\end{array}$ \\
\hline$\overline{B B}$ & Recciving Prep. \& Slipping & Small & 371,736 & $14(909$ & $18 \overline{18}$ & $-\$ 25$ \\
\hline$\overline{B B}$ & Receiving, Prep. \& Shipning & Large & 673,774 & 155313 & 1,926 & $\$ 4$ \\
\hline $\bar{C}$ & Incineration & Small & 373,297 & 1290 & 16 & $\$ 280$ \\
\hline$\overline{\mathrm{C}} \overline{\mathrm{C}}$ & Incineralion & Lirge & $1,120,296$ & 48223 & $59 \overline{8}$ & $\$ 23$ \\
\hline$\overline{\mathrm{D}}$ & Metal Melting & Snmall & 300,671 & 11935 & 148 & $\$ 25$ \\
\hline DD & Meli! Melting & Isirge & 643,824 & 123218 & 1,528 & $-\$ 5$ \\
\hline EE & Ślireduing/Compaction & Simiall & 116,187 & 12580 & -156 & $\$ 9$ \\
\hline EE & Shreduing/Compaction & Lirge & 345,259 & 130153 & $1,61 \overline{4}$ & $\$ \overline{3}$ \\
\hline $\bar{F}$ & Soliclification & Sniall & 273,206 & 14273 & 177 & $\$ 19$ \\
\hline rर & Sonfidificalion & Linge & 557,057 & $1476 \overline{5} 2$ & T,83i & $-\$ i$ \\
\hline ǴG & Vierificilion & Sullail & 475,523 & 2419 & 310 & $\$ 107$ \\
\hline $\bar{G} \bar{G}$ & Vitrification & Large & $1,(128,949$ & 80640 & $1,(1)(1)$ & $\$ 13$ \\
\hline नाI & Wet Air Oxidation & Smail & 288,238 & 11935 & 16 & $\underline{\$} 2 \overline{4}$ \\
\hline HII & Wet Air Oxidation & Large & 808,275 & 123218 & 598 & $-\$ 7$ \\
\hline II & Metail Sizing/ Decon. & Snıall & 232,069 & 1290 & 148 & $S(8)$ \\
\hline II & Metal Sizing/Decon. & Large & 522,169 & 48223 & 1528 & $\$ 11$ \\
\hline LL & GTCC Admin. Support & Small & 130,551 & 14999 & 186 & $\$ 9$ \\
\hline ILL & GTCC Admin. Support & Lirge & 238,429 & 155313 & 1,926 & $\$ 2$ \\
\hline
\end{tabular}


Table 18-4. Summary of cost versus capacity for storage facilities.

\begin{tabular}{|c|c|c|c|c|c|c|}
\hline $\begin{array}{l}\text { Module } \\
\text { Code }\end{array}$ & $\begin{array}{c}\text { Module } \\
\text { Description } \\
\end{array}$ & Facility & $\begin{array}{l}\text { Life Cycle Cost } \\
(\$ \times 1000)\end{array}$ & 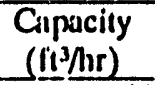 & 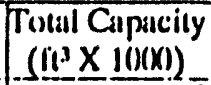 & $\begin{array}{c}\text { Unit Cost } \\
\left(\$ /\left[{ }^{3}\right)\right.\end{array}$ \\
\hline $\mathrm{Z}$ & $\overline{G T C C L L W}$ Vuull Storage Ficility & Smaill & 303,884 & 1.44 & $11 \overline{6}$ & $\$ 2,617$ \\
\hline $\mathbf{z}$ & $\overline{G T C} \overline{C L L W}$ Vaull Storage Facility & Large & 889,529 & $\overline{5.90}$ & $\overline{47} \overline{6}$ & $\$ 1,870$ \\
\hline $\mathrm{MM}$ & GTCC Silo Storage Facility & Small & 196,099 & 1.44 & 116 & $\$ 1,689$ \\
\hline$\overline{M M}$ & $\overline{\mathrm{G}} \overline{\mathrm{TCCS}}$ Silo Storage Facility & Large & 610,505 & 5.90 & $\overline{4} \overline{\overline{6}}$ & 51,283 \\
\hline
\end{tabular}


Table 18-5. Summary of cost versus capacity for disposal facilities.

\begin{tabular}{|c|c|c|c|c|c|c|}
\hline $\begin{array}{c}\text { Aindule } \\
\text { Code }\end{array}$ & $\begin{array}{c}\text { Cosi Module } \\
\text { Description }\end{array}$ & Facility & $\begin{array}{c}\text { Life Cycle } \\
\text { Cosi } \\
(\text { S } \times 1000)\end{array}$ & $\begin{array}{l}\text { Capacity } \\
\left(\left(1^{3} / \mathrm{hr}\right)\right.\end{array}$ & $\begin{array}{c}\text { Tulal } \\
\text { Capacliy } \\
\left(\text { (1 }^{3} \times 100 n\right)\end{array}$ & $\begin{array}{l}\text { Unit Cost } \\
\left(5 / t^{3}\right)\end{array}$ \\
\hline$\overline{K K}$ & Inicrmculate Depuli Disposal Facilicy & Small & 335,963 & 1.44 & 116 & $\overline{52,893}$ \\
\hline$k \mathrm{k}$ & iiicrmediale Depuli Dispessal Facilicy & Large & 58,2119 & 5.90 & 476 & 51,220 \\
\hline 0 & Disposal-Comnon Facilicy & Minimum & 147208 & 2.00 & $10 i$ & 5913 \\
\hline 0 & Disposal-Coummon Facilliy & Smn!I & 314,840 & 14.50 & ! 169 & 52,99 \\
\hline O & Disposal-Cuminon Focility & Mculum & $44 i 535$ & $46 . \overline{00}$ & $37(199$ & siig \\
\hline 0 & Disposal-Common Fociliiy & Large & 700,121 & 121.00 & 9757 & 572 \\
\hline$\ddot{p}$ & Engiuccred Dispesal & Minimum & 331.126 & 2.00 & 101 & 52,053 \\
\hline $\bar{p}$ & Engincered Disposal & Small & 49,048 & $1 \overline{4.50}$ & 1169 & 5422 \\
\hline 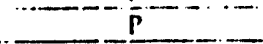 & Engincered Dispusal & Mculium & 887,595 & 46.00 & 3709 & 5239 \\
\hline$p$ & Enginecred Disposat & Large & $2,147,516$ & 121.00 & 9757 & $\$ 220$ \\
\hline$Q$ & Engincered Disposal & Minimum & 337,792 & 2.00 & 161 & $\$ 2,094$ \\
\hline $\mathbf{Q}$ & Engincercu Dispusal & Small & $499,05 \overline{3}$ & 14.50 & 1169 & 5427 \\
\hline $\mathbf{Q}$ & Engincered Dispossal & Mcuium & 901,566 & 46.00 & 3709 & 5243 \\
\hline Q & Enginecred Dispesal & Large & $2,174,993$ & 121.00 & 9757 & $\$ 223$ \\
\hline jj & Gculugic Dispossal & Small & 314,225 & 1.18 & 95 & 53,291 \\
\hline$--j j-\cdots$ & Gcologic Disposal & Large & $2,186,8199$ & 11.40 & 920 & $52,37 \overline{78}$ \\
\hline $\bar{R}-(\overline{D O} \bar{E})$ & Sinaliow Disposal of Contact llandled & Small & 150,958 & 6.00 & $5(0)$ & $5 \overline{3} 12$ \\
\hline$R-(\overline{D O E})$ & Shailow Disposal of Coniacl Handled & Large & 165,312 & 25.00 & 2000 & 582 \\
\hline$\overline{R-(C o m m e r c i a l)}$ & Shallow Disposal of Remole Handled & Small & 42.029 & 0.51 & 40 & 51,066 \\
\hline $\bar{R}-($ Commerciil $)$ & Shallow Disposal of Conlaci Handled (1) & Large & & & & 581 \\
\hline $\bar{R}-($ Commerciili) & Shallow Disposal of Remole Handled (1) & Large & & & & 5.310 \\
\hline
\end{tabular}

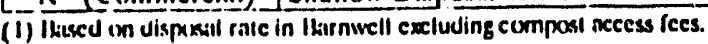


Transportation costs for LLW and GTCC LLW, assuming shielded cask shipments, are calculated by multiplying the below-listed factors by the one-way distance (in miles) times the volume of the waste (in cubic feet) to be shipped. The variable and fixed transportation cost factors listed below are based on shipping $50 \mathrm{ft}^{3}$ per cask shipment:

- Up to 30 miles: $\$ 23.2 \times 10^{-2} / \mathrm{ft}^{3}$ per mile (+ $\$ 880$ per shipment)

- $\quad 30$ to 200 miles: $\$ 13.7 \times 10^{-2} / \mathrm{ft}^{3}$ per mile (+ $\$ 880$ per shipment)

- Over 200 miles: $\$ 9.8 \times 10^{-2} / \mathrm{ft}^{3}$ per mile (+ $\$ 880$ per shipment).

\subsubsection{Total PLCC Estimates}

Add items from 18.5.1 through 18.5.6 to yield the total PLCC estimates for the selected waste management scenario.

\subsection{Limitations}

WMFCI reports are a useful tool for developing ILCC estimates of DOE site-wide waste management scenarios. Costs are developed for initial project planning, demonstration, design, construction of production facility, operation and maintenance, and decommissioning and closure. Only facilities subject to the following key conditions are appropriate for the cost data presented in WMFCI reports:

1. Facilities are designated as a Major Project ( $\$ \$ 0$ million) or Major System Acquisition (MSA) (>\$100 million) project as defined in DOE Order 4700.1, "Project Management System." To apply WFMCI, each project must go through the DOE acquisition process defined by this order. Key milestones for the acquisition process and a schedule for typical waste management facility planning, construction, and operation are given in Figure 18-1.

2. Facilities are subject to:

a. Environment, safety and health (ES\&H) requirements including National - Environmental Policy Act of 1969 (NEPA) and safety assurance reviews according to DOE orders and regulations (See Environmental Compliance Guide, DOE/EV-1032). Activities include the preparation of an Environmental Impact Statement (EIS), Safety Analysis Report (SAR), and related activities.

b. RCRA Permitting - Treatment, Storage and Disposal permit.

c. Other permits such as National Emission Standard for Hazardous Air Pollutants (NESHAP), Clean Air Act, state and local permits.

c. Design criteria given in DOE Order 6430.1A.

3. The five treatment cost modules were strategically selected such inat all of the GTCC LLW and a majority of the DOE equivalent waste streams can be addressed. However, there is a wide range of DOE special waste streams and some may not be specifically treatable by the given processes. In such situations, the unit operation method can be used to develop costs for special waste streams. 


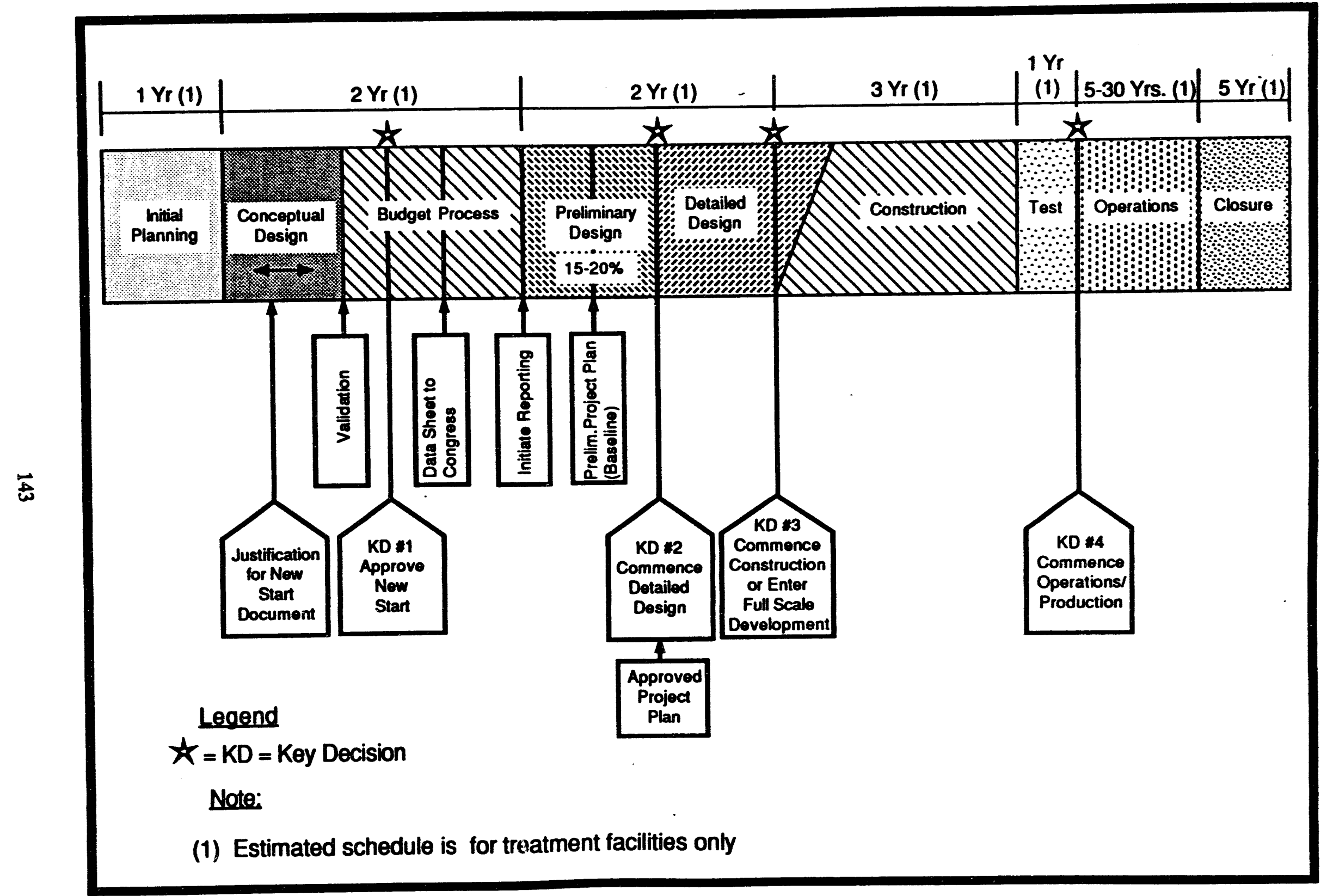

Figure 18-1. Key events in the acquisition process. 
4. PLCC estimates are based on condition at the INEL. Cost differences due to site-specific cost factors are assumed to be within the variance limits of these cost estimates. Table 18.6 provides a guide for comparing DOE site-specific cost factors relative to the INEL. 
Table 18-6. Site-specific cost factors.

\begin{tabular}{|c|c|c|c|c|}
\hline $\begin{array}{c}\text { Site } \\
\text { (index area) }\end{array}$ & $\begin{array}{l}\text { Material } \\
\text { index }\end{array}$ & $\begin{array}{l}\text { Installation } \\
\text { index }\end{array}$ & $\begin{array}{l}\text { State sales } \\
\text { tax rate }\end{array}$ & $\begin{array}{l}\text { Cost factor }(C F \\
\text { relative to } I_{N E L^{b}}\end{array}$ \\
\hline $\begin{array}{l}\text { INEL } \\
\text { (Boise) }\end{array}$ & 98.9 & 88.4 & $5.5 \%$ & 1.0 \\
\hline $\begin{array}{l}\text { Los Alamos National } \\
\text { Laboratory } \\
\text { (Albuquerque) }\end{array}$ & 101.7 & 82.7 & $4.75 \%$ & 0.983 \\
\hline $\begin{array}{l}\text { Lawrence Livermore } \\
\text { National Laboratory } \\
\text { (Stockton) }\end{array}$ & 99.2 & 116.8 & $8.25 \%$ & 1.130 \\
\hline Oak Ridge (Knoxville) & 98.1 & 72.4 & $5.5 \%$ & 0.935 \\
\hline $\begin{array}{l}\text { Portsmouth } \\
\text { (Columbus) }\end{array}$ & 99.5 & 95.9 & $5.0 \%$ & 1.031 \\
\hline Rocky Flats (Denver) & 101.1 & 86.9 & $3.0 \%$ & 0.998 \\
\hline Hanford (Spokane) & 103.5 & 99.7 & $6.5 \%$ & 1.054 \\
\hline $\begin{array}{l}\text { Savannah River } \\
\text { (Columbia) }\end{array}$ & 97.8 & 65.1 & $5.0 \%$ & 0.906 \\
\hline Reference: EGG-WTD-10 & 33,1992 & & & \\
\hline
\end{tabular}




\section{REFEPENCES}

Feizollahi, F. and D. E. Shropshire, 1992a, Waste Management Facility Cost Information Estimating Data, WTD-92-10443, October 1992.

Feizollahi, F. and D. E. Shropshire, 1992b, Alpha Low-Level Stored Waste Systems Design Study, EGG-WTD-10254, August 1992.

Feizollahi, F. and D. E. Shropshire, 1993a, Waste Management Cost Information Report for Spent Nuclear Fuel, EGG-WM-10670, March 1993.

Feizollahi, F. and D. E. Shropshire, 1993b, Waste Management Cost Information Estimating Data for Greater-Than-Class C and DOE Equivalent Special Case Waste, EGG-WM-10709, June 1993.

Hulse, R. A., 1991, Greater-Than-Class C Low-Level Radioactive Waste Characterization: Estimated Volumes, Radionuclide Activities, and Other Characteristics, DOE/LLW-114, 1991.

Peters, R. D., 1991, Evaluation of Treatment Technologies for Greater-Than-Class C Low Level Waste, September 1991.

Lopes, D. A. and J. A. Logan, 1992, DOE-Generated G-T-C.C LLW at the INEL, and Prospects for Its Disposition, September 1992.

Fischer, D. K. and T. W. Garrison, 1992, Treatment of Greater-Than-Class C Low-Level Waste for Dedicated Storage, DOE/LLW-159, November 1992. 


\section{Appendix A}

\section{Methodology, Assumptions, and Bases}




\section{Appendix A}

\section{Methodology, Assumptions, and Bases}

This appendix contains the cost estimating methodology, assumptions and technical bases that are used to develop the PLCC estimates. Specific additional assumptions and bases for each cost module are given in the main body of this report and EG\&G Idaho report Waste Management Facilities Cost Information Estimating Data for Greater-Than-Class $C$ and DOE Equivalent Special Case Waste, EGG.WM-10709.

\section{A-1. COST ESTIMATING METHODOLOGY}

The cost estimating approach, shown in Figure 1-2, is based on the development of well documented PLCC estimates for various facility capacities. Initially, a capacity range for each type of facility was established by studying the currently stored and future projections of GTCC LLW quantities. Data from the study defined baseline capacities for two different facility sizes (small and large). These capacities are facility specific and have been defined in the main body of this report under the appropriate sections.

Using the two facility sizes, a preconceptual design package for each facility (referric to as facility cost module) was developed and used as the basis for the PLCC cost estimatcs. Each preconceptual design package includes a PFD with mass flow rates, a SSL, and a summary F\&OR. The design packages use as much of the data from existing or planned DOE facilities as possible. New designs were generated only if existing data were not available.

The PFD's and SSL drawings were developed to the individual unit operations level. After unit operations were defined, major equipment lists, building configuration and square footage requirements were established and cost estimates for each facility was developed.

Costs for each facility were divided into six components, each of which were estimated separately. Equipment costs were obtained either by soliciting budgetary costs from the suppliers, using existing data, or making engineering judgements. Building costs were estimated by either generating detailed material quantities, labor hours, and the related rates, or by multiplying the unit operation square footage by a set of preestablished building cost unit rates. After the various components were estimated, they were added to obtain the total facility PLCC estimate.

To aid cost estimating flexibility, the facilities needed for managing the waste, including support facilities such as administration, were estimated as separate facility cost modules. This approach allows consideration of scenarios that involve existing facilities where some or all of the required functions are already in place.

\section{A-2. WMFCI MODEL}

The cost eucimating data were entered into a file of inter-linked spreadsheets in Lotus 1-2-3 v.3.1 software. These spreadsheets, referred to as WMFCI model, outline detailed costs, cost factors, and unit rates for each facility cost module. A hard copy of the spreadsheets is included in EG\&G Idaho report EGG-WM-10709. 


\section{A-3. TECHNICAL BASES AND ASSUMPTIONS}

Technical assumptions that apply to all facility cost modules in this report are discussed in the following sections. Facility-specific assumptions are given in the main body of this report.

\section{A-3.1 Input Waste Sources}

The TSD facilities covered by this report generally apply to all waste streams requiring remote handling and processing techniques. There are two major sources of waste that fall into this category:

- Commercial scctor GTCC LLW: Commercial sector GTCC LLW has a radioactivity level that exceeds the limits set by the NRC for Class $C$ low-level radioactive waste (10 CFR 61.55), but is not within the historical definition of high-level waste (HLW), which normally consists of spent fuel and first-cycle reprocessing waste. As a result, GTCC LLW falls outside the NRC regulations for disposal of either LLW or HLW. GTCC LLW is generated by a wide variety of operations which include manufactur ss of devices containing sealed sources, fuel fabricators or burnup laboratories, nuclear utilities, users of carbon 14, nuclear research reactors, academic institutions, waste service companies, federal and state agencies, and medical research institutes.

- DOF equivalent waste: DOE generated waste is normally classified according to DOE Order 5280.2A which does not have a specific classification similar to GTCC. However, there are some DOE generated waste stream that have similar properties. In general, the DOE generated waste equivalent to the commercial GTCC LLW is the LLW that cannot be disposed of in the operating DOE shallow-land disposal sites or the Waste Isolation Pilot Plant (WIPP) repository.

It is assumed that the input waste will be shipped to the GTCC LLW facilities by truck.

\section{A-3.2 Waste Quantities and Facility Sizes}

\section{A-3.2.1 Input Waste Quantities}

Table 1-1 contains a breakdown of the commercial GTCC LLW sources, types and volume projections. These data are the Base Case projections given in DOE-LLW/114 (Hulse 1991). The DOE equivalent waste is estimated to be approximately $1,201,900 \mathrm{ft}^{3}$ (Clark 1991) and a detailed breakdown is not available at this time. A majority of this waste is stored in canyon cells at the Hanford site.

\section{A-3.2.2 Facility Sizes and Throughput}

Two different facility sizes, small and large, are considered for each of the facility cost modules shown in Figure 1-1. The commercial GTCC LLW quantities are used for sizing the throughput :or the small facilities and the DOE equivalent waste quantities is used as the basis for sizing the large facilities.

The treatment facility throughput is determined by assigning each waste category to the applicable treatment facility options. 


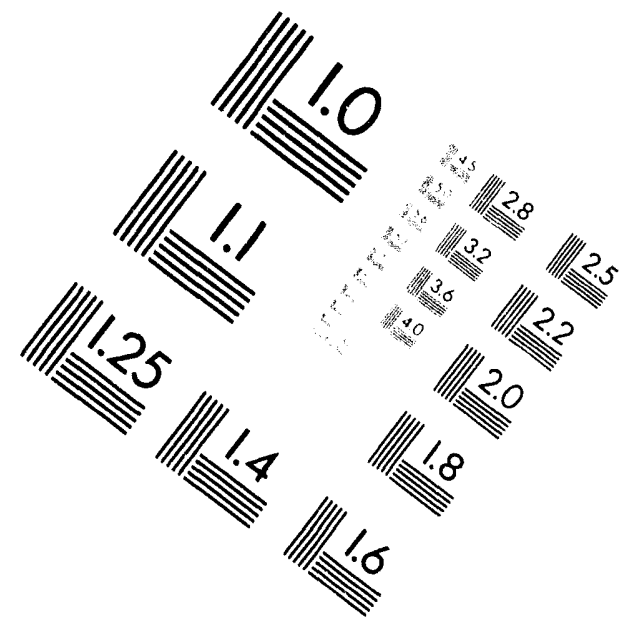

\section{Centimeter}

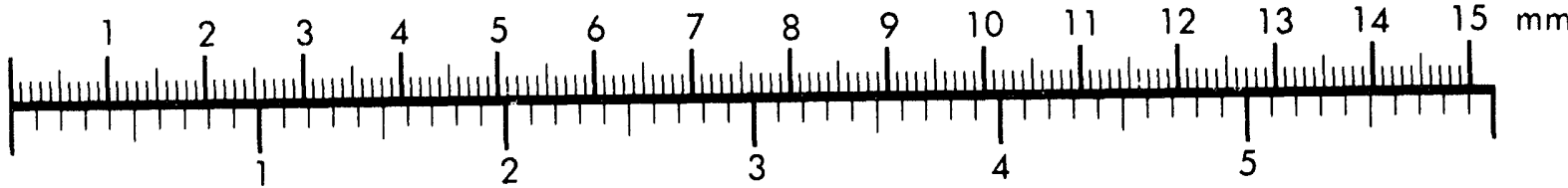

Inches
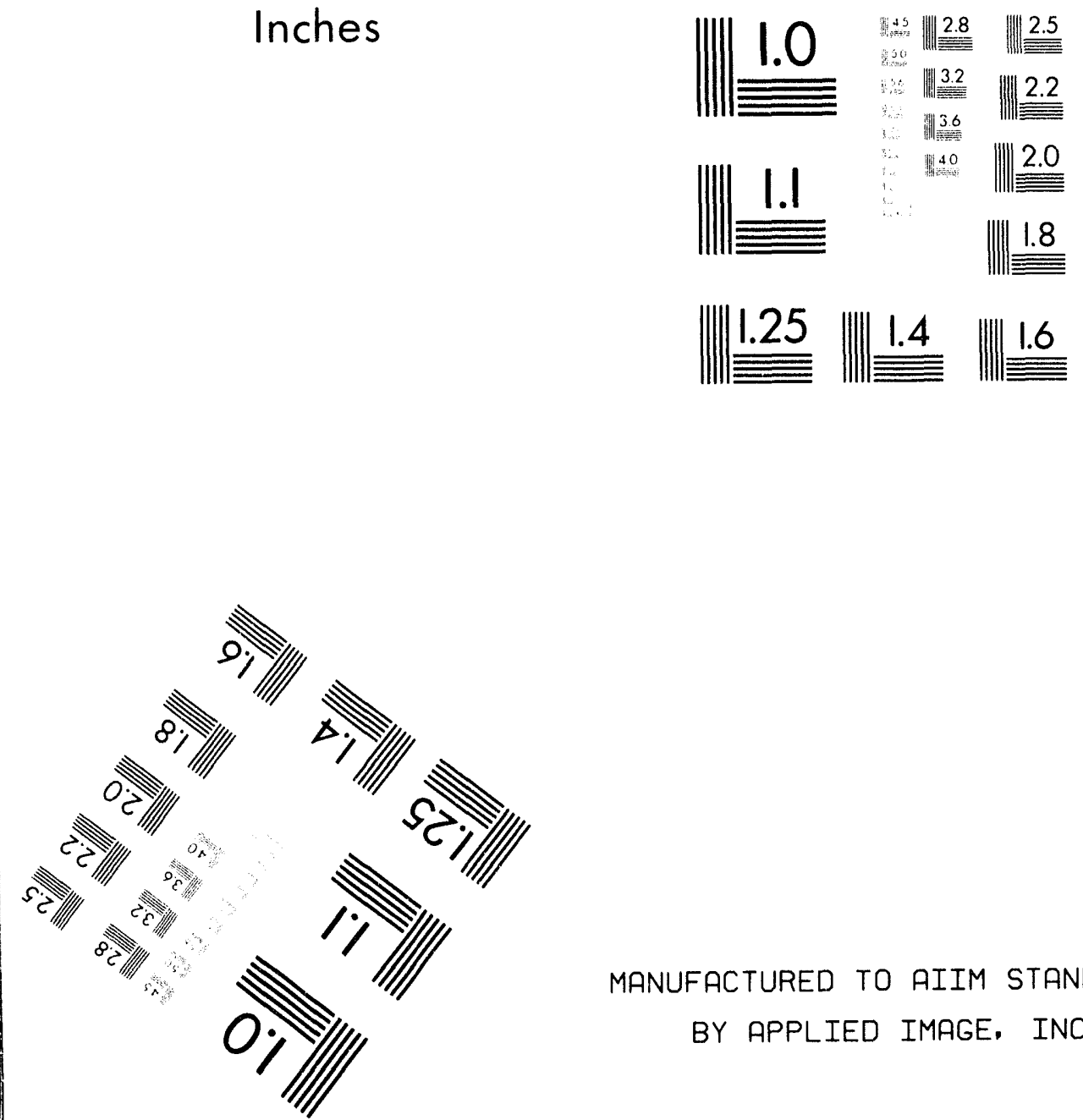

MANUFACTURED TO AIIM STANDARDS

BY APPLIED IMAGE. INC.

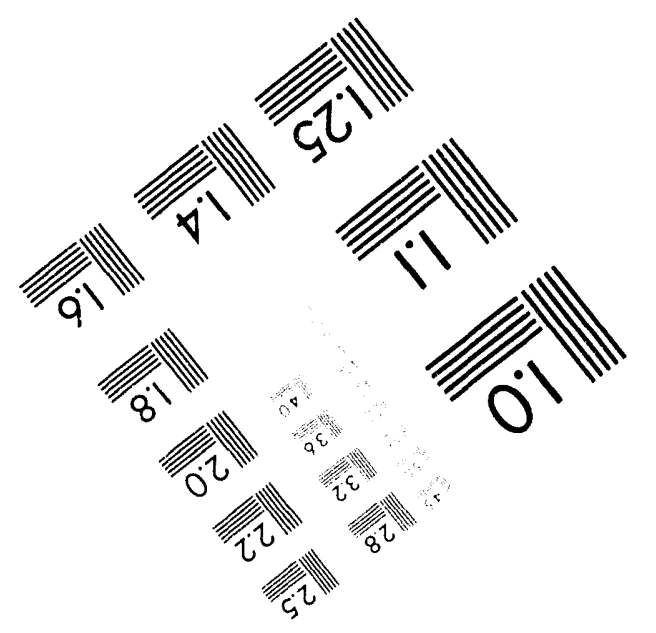



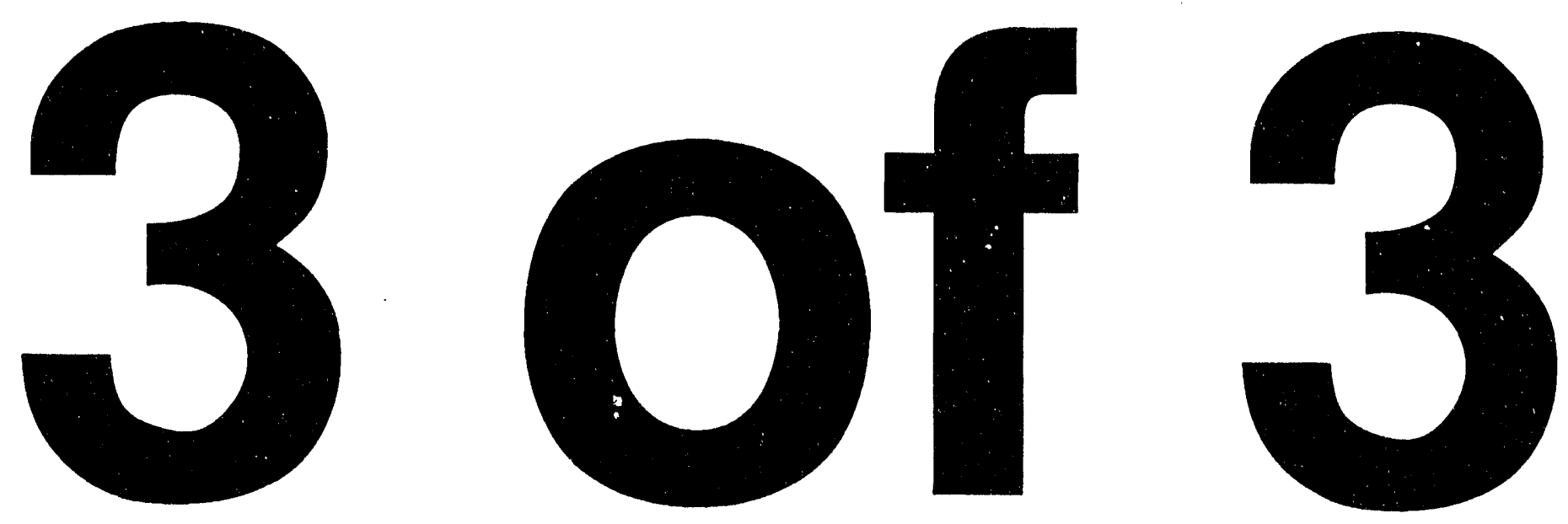
For detcrmining the disposal facilities size, it is assumed that the small facility will receive only the commercial GTCC LLW. Furthermore, it is assumed that the GTCC LLW volume after treatment will be the same as the volume before treatment. The size of the large disposal facilities is based on the assumption that they will receive all of the commercial GTCC LLW and $30 \%$ of the DOE equivalent waste. This $30 \%$ number is obtained by assuming that treatment process will convert $70 \%$ of the input waste to LLW suitable for disposal in a shallow land disposal facility.

\section{A-3.3 Waste Characteristics}

The commercial GTCC LLW is grouped according to seven types and is presented in Table 1-1. These waste types fall under the 12 waste categories shown in Figure A-1. In the following sections, the general characteristics of each of the seven categories and the specific characteristics of the commercial GTCC LLW subcategories are described. ${ }^{\text {a }}$ Since a breakdown of the DOE equivalent waste is not available at this time, it is assumed that this waste has the same subcategories as the commercial GTCC LLW.

\section{A-3.3.1 Combustible Solid Waste}

Combustible solids incluue waste paper, wood, plastics, clothing, rubber, etc. Following is the specific GTCC LLW subcategory:

- Compactible trash: Compactible GTCC LLW trash consists mostly of combustible materials such as plastic waste, paper, cardboard, general laboratory consumables, and disposable garment. It is assumed that this waste is compacted in 55-gal. drums by the generator and shipped to the GTCC LLW management facilities.

\section{A-3.3.2 Semicombustible Solid Waste}

Semicombustible solids are waste having a mixture of combustible and inert materials. Examples are cemented sludge, volatile organic compounds (VOCs) contaminated soil/debris, and asphalt. Following are the specific GTCC LLW subcategories:

- Solidified resins: It is assumed that this waste consists of cemented IX resin solidified in 55-gal. drums.

- Solidified organic waste: This waste consists of organic liquids that have been either retained in an absorbent material, solidified in cement, or mixed with a plaster and cement combination.

- Cartridge filters: Spent cartridge filters are from nuclear power plant control rod drive filters, seal water injection and return filters, fuel pool filters, reactor coolant make-up water filters, and purification system filters. The cartridge filters range from 0.1 to $1 \mathrm{ft}^{3}$. It is assumed that filt $\mathbf{s}$ are made from metal frame and organic (paper, polymer and fiberglass) media. It is further assumed that filters are packaged in 55- or 30-gal drums by the generator and shipped to the GTCC LLW management facilities. Some of the higher activity spent filter elements are shipped in shielded drums with an inner concrete lining.

a. A description of the remaining seven waste types is presented in Appendix A of the first WMFCI report EG\&G report EGG-WTD-10443 (Feizollahi and Shropshire 1992a). 


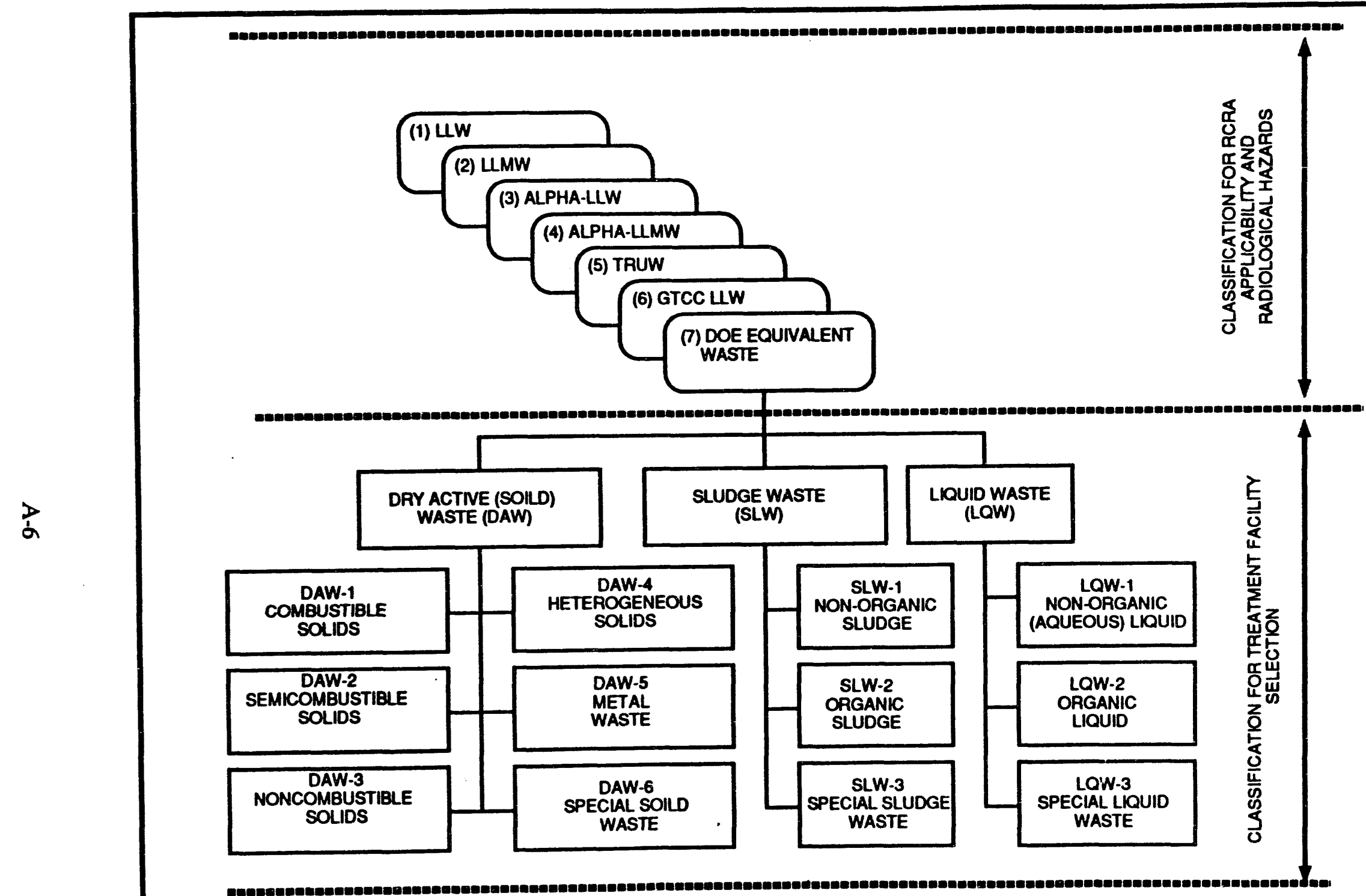

Figure A-1. General categories of radioactive waste used for PLCC estimates. 
- Filter media: F:'ter media is assumed to be powder filter media such as powdered ion exchange resins, solka-floc, diatomacious earth, zeolite, glass, or polymer fibers. it is further assumed that filter media is either packaged in 55-gal. drums or in high integrity containers (HICs) licensed the NRC. The TMI-2 filter media is packaged in concrete HICs.

\section{A-3.3.3 Noncombustible Solid Waste}

Noncombustible solids include ash, soil, concrete, brick, construction debris, etc. Following is the specific GTCC LLW subcategory:

- Noncompactible trash: Noncompactible trash consists of generally structural material, soil, concrete or other material not amenable to compaction due to compressive strength. The only reported radionuclides in noncombustible trash are transuranic, (TRU) and are about 10 to $75 \mathrm{Ci}$ per cubic meter. It is assumed that this waste is shipped to GTCC management facilities in 55-gal. drums.

\section{A-3.3.4 Contaminated Metals}

This waste includes ferrous and nonferrous metal waste. The waste category is further grouped as nonlead and lead contaminated metals. However, it is assumed that all of the GTCC LLW metals are nonlead contaminated waste. Below is a description of various subcategories of the GTCC LLW metals:

- Activated metals: Activated metals are generated primarily from nuclear reactor decommissioning and operations. The large activated metal components from reactor decommissioning are core shrouds and core barrels. It is assumed that these components are size reduced and placed in containers (either in 55-gal. drums or in canisters sized for shipment by spent nuclear fuel casks) at the generator sites and shipped to the GTCC LLW management facilities. Other smaller components generated during both operations and decommissioning are control rod blades, in-core instruments, and thimble plugs. These components are also assumed to be packaged in drums or canisters at the generator sites and shipped to the GTCC LLW management facilities. Metals are assumed to be stainless steel and other types of ferrous alloys.

- Contaminated equipment: Contaminated equipment is mainly metallic waste and consists of contaminated pumps, valves and other process components. It is assumed that the smaller components will be placed in 55-gal. drums by waste generators and shipped to the GTCC LLW management facilities. Larger components will be placed in metal bins or boxes.

- Metals from operations: This waste category is assumed to be the same as contaminated equipment discussed above.

- Metal shavings: Metals shavings are waste generated from sawing, machining and grinding of GTCC LLW metals. It is assumed that this waste is shipped to GTCC LLW management facilities in 55-gal. drums. 


\section{A-3.3.5 Heterogeneous Solid Waste}

Heterogeneous solids include waste containers that require special sorting and processing. Examples are containers potentially containing compressed gas cylinders, or mercury contaminated waste. Containers that require sorting to facilitate treatment of different waste processing streams (e.g., a container having metal and combustible solids) also fall in this category. Both the compactible and noncompactible waste subcategories described in Sections A-3.3.1 and A-3.3.3 are assumed to be heterogeneous waste requiring special sorting.

\section{A-3.3.6 Special Solid Waste}

Special wastes are those wastes that exist in small quantities, or have special processing and handling requirement not provided by the main treatment systems provided at the facilities. These waste are generally treated and handled on a case-by-case basis. A description of the GTCC LLW special waste subcategories is presented below:

- Mixed fuel oxides: The existing inventory of the mixed fuel oxides waste resulted from fuel fabrication activity and from the examination of irradiated mixed oxide test fuel rods. It was generated by a fuel cabricator and an industrial research and development facility. It is assumed that this waste is packaged in drums by the generators and shipped to the GTCC LLW management facilities.

- Sealed sources: Sealed sources are usually small, sealed stainless steel capsules containing one radionuclide and decay products. Sealed sources become waste when the source capsule develops a leak, when sources are no longer of use to the owner, or when the short-lived sources decay. Most of the sealed sources are remote-handled although shielding around the source may allow contact handling. It is assumed that all the sources require remote handling and that they are packaged in pigs (shield overpacks) by the generator and shipped to GTCC LLW management facilities.

\section{A-3.3.7 Organic Sludges}

Following is a description of the commercial GTCC LLW organic sludge waste:

- Ion-exchange resin: Ion-exchange (IX) resin waste is generated as a result of routine decontamination of the nuclear reactor coolant loop cooling water. The resins are organic polymer beads and are classified as combustible material. Before shipment, resins are dewatered and shipped in wet form with minimal free water. Dewatered resin are shipped in vessels ranging from 5 to $70 \mathrm{ft}^{3}$ in volume.

\section{A-3.3.8 Waste Radioactivity Properties}

Assumptions regarding the waste $r$ tioactivity, hazardous material contents are as follows:

- Design basis radionuclide inventories for GTCC LLW have not available at this time. For shielding purposes, the thickness of the walls in areas handling radioactive waste are assumed to be the same as those provided for the radioactive waste treatment systems at the commercial nuclear power plants. 
- $\quad$ For worker and public radiation protection purposes, the main concerns during processing are high gamma radiation and airborne alpha contamination (similar to that potentially released during TRU waste processing operations).

\section{A-3.4 Waste Form Requirements}

It is assumed that the primary treatment objective are to render the waste suitable for safe disposal in any of the disposal facilities shown in Figure 1-1. Furthermore, it is assumed that potential waste forms acceptable for disposal are one of the following:

- Waste Form 1 - Leach resistant high integrity glass/rock: Produced by vitrification plants, this waste form is a leach-resistant, high-integrity glass- or rock-like material. The waste form also complies with TRUPACT II TRU transportation packaging criteria.

- Waste Form 2 - Solidified: This waste form is produced by solidification plants and complies, if needed, with the Land Disposal Restriction (LDR) requirements. If the waste contains organics or other RCRA controlled substances, it will be pretreated by the EPA specified technologies (e.g., incineration or macro-encapsulation).

- Waste Form 3 - Repackaged Waste: This waste form is produced by shredding and compacting the waste to maximize volume reduction. Compaction will also increase the waste density.

It is assumed that the output waste from all treatment facilities are packaged in 55-gal. drums with the exception that the shredding/compaction facility output is packaged in 85-gal. drum overpacks.

\section{A-3.5 Treatment Options}

Several treatment options are provided for each waste type to allow flexibility during the waste management option analysis tasks. For example, if the strategy is to dispose of the waste in a deep geological repository, treatment systems producing Waste Form 3 will probably be the most appropriate. For engineered or intermediate depth disposal, Waste Form 1 which offers the highest integrity and leach resistance may be the most appropriate choice.

Key considerations employed in selecting alternative treatment methods for each waste type is discussed below. Table A-1 shows the selected baseline capacities for each treatment option. For facility concept development purpose, it is assumed that the receiving, preparation and shipping facility (cost module BB) includes a cubicle where special solid waste category is treated by portable systems provided on a case-by-case basis.

\section{A-3.5.1 Combustible Solid Waste}

Treatment options for combustible waste category are as follows:

- Compactible trash: Options for treatment of compactible trash are incineration followed by vitrification (Waste Form 1) or solidification (Waste Form 2) of the ash. Ash can also be shredded and encapsulated in a matrix to produce Waste Form 2, or shredded and compacted to produce Waste Form 3. 


\section{A-3.5.2 Semicombustible Solid Waste}

Treatment options for semicombustible waste category are as follows:

- Solidified resins: Cemented IX resin waste must be crushed and shredded before processing. Applicable processes are either vitrification (Waste Form 1), incineration followed by vitrification (Waste Form 1), incineration followed by solidification (Waste Form 2), or wet air oxidation followed by solidification (Waste Form 2).

- Solidified organic waste: Process options for this waste stream are the same as the solidified IX resin waste.

- Cartridge filters: Cartridge filters produced from light water reactor (LWR) primary system coolant cleanup are highly radioactive and, hence, minimal handling is desirable. Process options are either vitrification (Waste Form 1), incineration or wet air oxidation followed solidification of the inert solids (Waste Form 2), and macro-encapsulation (Waste Form 2), which will consist of placing the filters in a cavity inside a shielded container and pouring cement grout or other encapsulation matrix into the cavity. The grout fills the void in the cavity and seals the package.

- Filter media: Filter media can be either vitrified (Waste Form 1), solidified (Waste Form 2) or packaged in HICs. Filter media can also be processed by wet oxidation process.

\section{A-3.5.3 Noncombustible Solid Waste}

Treatment options for noncombustible waste category are as follows:

- Noncompactible trash: The principal radionuclides in noncompactible trash are transuranic elements. Assuming that the nuclides only contaminate the surface of the waste material (i.e., not embedded in the waste matrix), treatment alternatives are vitrification (Waste Form 1), macro-encapsulation (Waste Form 2), and compaction/shredding (Waste Form 3).

\section{A-3.5.4 Heterogeneous Solid Waste}

Heterogeneous waste is first sorted according to the criteria established by the treatment facility. After sorting, the segregated waste is sent to the treatment processes provided at the facility.

\section{A-3.5.5 Metal Waste}

Treatment options for metal waste category are as follows:

- Activated metals: Activated metal waste is contamin ted with radionuclides embedded in the metal matrix; hence, it is leach resistant and expected to meet the physical and chemical requirements of shallow land, intermediate depth, and deep geological disposal environment. The primary incentive for treatment is volume reduction and removal of the air pockets from the package. Treatment options for activated metals are melting (Waste 
Form 1), macro-encapsulation ${ }^{b}$ (Waste Form 2), or shredding/compaction (Waste Form 3). All three methods will require initial cutting and size reduction. Macro encapsulation will eliminate air pockets but will increase the overall waste volume.

- Contaminated equipment: Unlike irradiated metals, contaminated equipment has primarily surface contamination. When exposed to a conducive environment, the surface contamination can become mobilized away from the waste package. Treatment options for this waste is the same as the activated metal waste. In addition, this waste can be decontaminated to remove surface contamination so that the contaminated metal can be reclassified as LLW and disposed of in shallow land disposal sites. However, the by-product from decontamination operation will be GTCC LLW. In this task, it is assumed that a decontamination option can reclassify $70 \%$ of the metals to LLW, while $30 \%$ will remain as GTCC LLW.

- Metals from operations: This waste category is assumed to be the same as contaminated equipment discussed above.

- Metal shavings: Metals shavings are in powder form and will require stabilization to meet the disposal requirements. Treatment options are vitrification or metal melting (Waste Form 1), and solidification (Waste Form 2).

\section{A-3.5.6 Special Solid Waste}

Treatment options for Special Solid Waste are as follows:

- Sealed sources: Sealed sources that are already packaged in small capsules can be encapsulated (Waste Form 2) by placing them in a cavity inside a shielded container and pouring cement grout or other encapsulation matrix into the cavity. The grout fills the void in the cavity and seals the package. Alternatively, sealed sources can be either melted or vitrified (Waste Form 1).

- Mixed fuel oxides: The mixed oxide fuel pellet waste has a uranium or plutonium oxide matrix that has low solubility in ground waster and, hence, is leach resistant. If the fuel oxides are to be disposed in a repository, they simply can be repackaged (Waste Form 3) in suitable canisters consistent with the plans for disposal of un-processed spent nuclear fuel in a repository. For other disposal environments, the waste could be treated by vitrification, (Waste Form 1) or encapsulation (Waste Form 2).

\section{A-3.5.7 Sludge Waste}

Treatment options for sludge waste are as follows:

- Ion-exchange resin: As with cartridge filters, ion exchange resins are highly radioactive and minimal processing or handling is desirable. Furthermore, the ion exchange beads swell when absorbed with water. This swelling property makes resin solidification in an

b. British Nuclear Fuel Limited (BNFL) uses a cement based macro-encapsulation process for packaging of irradiated metals (fuel cladding and hardware) generated form the Magnox fuel reprocessing operations in Sellafield, England. The packaged product from the encapsulation facility, Encapsulation Plant 2 (EP2), is compatible with an interim storage in concrete vaults and final disposal in an underground repository. 
aqueous based agents (such as portland cement) impractical because the force exerted by the swelling cracks or crumbles the solidified matrix. Treatment options for this waste stream are vitrification (Waste Form 1) or incineration followed by solidification of the ash (Waste Form 2). Incineration of highly radioactive resin may not be desirable due to a potential for discharging radioactivity into the environment and a complex design for remote operation and maintenance of the incinerator. In place of an incinerator, a lowtemperature oxidation process such as wet oxidation (see Figure A-1) may be used. The product of wet oxidation is concentrated solutions for an evaporator which can be solidified in cement based matrix or other agent available in the market (Waste Form 2). Another processing option is packaging in high-integrity containers (HICs) designed for long-term isolation of the waste.

\section{A-3.6 Storage Options}

GTCC LLW storage requires shielded enclosures and can be stored in a facility similar to the vault concept developed for the SNF hardware and scrap metal storage facility (cost module Z). Hence, information for cost module Z (see EGG-WM-10670) is used for defining GTCC LLW storage requirements. An additional storage cuncept based on silo storage of the treated waste containers is also developed and estimated in this report.

\section{A-3.7 Disposal Options}

Disposal options for GTCC LLW are engineered shallow land disposal, deep geological repository similar to Yucca Mountain Repository, and intermediate depth disposal. For shallow land disposal option, data from modules $P$ and $Q$ (see EGG-WTD-10443) are repeated in this report. For the deep geological disposal option, disposal cost data from PNL report (Clark, 1991) are used. For intermediate disposal, a preconceptual design package is prepared and used to develop a PLCC estimate.

There are two general concepts for intermediate depth disposal: mined cavity (i.e., a vertical shaft leading to horizontal sections of a tunnel where disposal cells are located), and drilled hole (i.e., waste package being placed in the bottom section of a vertical shaft). The final selection of a concept will be based on results of a performance assessment that is currently ongoing. This report contains a preconceptual design package and a PLCC estimate for an intermediate depth disposal based on mined cavity concept using layered placement. This concept is selected because it uses common construction methods.

\section{A-3.8 Anchor Facilities}

Since there are some similarities, the TSD facilities considered for GTCC LLW use data from the TSD facilities considered for the LLW/MLLW and alpha LLW/MLLW waste streams (see EGG-WTD-10443).

\section{A-3.9 Facility Design Requirement Assumptions}

\section{A.3.9.1 General Assumptions}

The facility preconceptual designs follow these general assumptions:

- Facilities handling GTCC LLW are classified as seismic category I structures. All buildings that handle GTCC LLW are classified as a moderate hazard facility according to University of California Research Laboratories (UCRL) 15910. 
- The facilities are designed in accordance with applicable local, state and federal regulations. Specifically, RCRA places design constraints on the storage and treatment process, and performance specifications on the waste stabilization processes.

- All equipment systems and component critical operations related to handling of GTCC LLW are safety classed. They have high-quality, low-maintenance features to keep personnel exposure as low as reasonably achievable (ALARA). Remote operations are used to the greatest extent practical.

- The individual unit operations are sized to handle at least $125 \%$ of the mass flow rates as shown on the process functional diagrams.

- Public, employee, and environmental exposures to hazardous and radioactive material will be ALARA.

- The scoping study layout for each facility is based on the following assumptions:

- Surge capacity for indoor storage of GTCC LLW drums is 2-6 weeks.

- The preconceptual design of cubicles for GTCC LLW processing areas is based on a double confinement system.

- Special design considerations for criticality safety will be required for all GTCC LLW treatment and disposal facilities.

\section{A-3.9.2 Treatment Facility Support Functions}

Support functions included for all treatment facility cost modules include but are not limited to:

- HVAC nonprocess

- Fire protection

- Electrical (including emergency)

- Process control and data logging

- Radiation instrumentation

- Bulk chemical and additive supply and storage

- Storm water runoff control

- Waste water treatment (hazardous, radioactive, and sanitary).

Input from the site includes utilities, service water, normal and emergency power, and communications. Laboratory and personnel decon areas are designed to handle radioactive material. 
Structures housing personnel and nonradioactive components are designed per the Uniform Building Code (UBC). Laboratory and personnel decon areas are designed for handling radioactive material.

\section{A-3.9.3 Administration Support Facility Functions}

Support functions for the administration facility include but are not limited to:

$\therefore \quad$ Security

- Personnel decontamination (radioactive and hazardous)

- Noncontaminated maintenance

- Health physics

- Sanitary facilities

- Work control/personnel support

- Interior and external (public relations) communications

- Spill or emergency response provisions (hazardous and radioactive)

- General analytical laboratory

- Environmental field sampling

- Environmental regulatory reporting and records management.

Every facility described in this report includes the following interfaces: facility communication, alarm systems including telephone, evacuation, fire, security alarm, and public address systems. All treatment processes are programmed for automatic shutdown if the fire system or the evacuation alarm is activated.

\section{A-3.9.4 Scoping Study Layout General Assumptions}

Scoping study layouts (SSLs) are shown in EG\&G Idaho report Waste Management Facilities Cost Information Estimating Data for Greater-Than-Class C and DOE Equivalent Special Case Waste, WTD-WM-10709. To facilitate ease of maintenance and reduce employee exposures, each of the main GTCC LLW handling and radioactive waste processing unit operations are located in a dedicated shielded cubicle. Major components are controlled from behind shield walls by either slave manipulators or from a centralized control room. I' 'aintenance cells are provided for key components. Also, each facility includes space for support functions such as electrical, HVAC, and mechanical and utility systems.

\section{A-3.10 Facility Operation}

The PLCC estimates in this report are based on the assumption that GTCC LLW inventories will be processed in treatment facilities, placed in storage facilities, and disposed of during a 20 -year 
operating period. During this period, the TSD facilities will operate 24 hours/day, 5 days/week, 240 days/year, and assumes $70 \%$ plant availability during operation. This is equivalent to 168 days/year, or 4032 hours/year of operation. Facilities with small capacities, where a three-shift operation is not justified, single shift per day or part-time shifts are assumed.

\section{A-4. COST BASES AND ASSUMPTIONS}

The following general assumptions are made for the PLCC estimates contained in this report:

- $\quad$ PLCC estimates for new facility construction are based on the conditions at the INEL site including utility, labor and the related design, construction, operation, and management factors.

- PLCC estimates are based on 1992 dollars. The time value of money or escalation for expenditures occurring at different time frames has not been considered in the estimates.

The costs for each facility are divided into these six components: studies and bench-scale tests, demonstration, production facility construction, operations budget funded activities (preoperation costs), operating and maintenance, and decontamination and decommissioning. Methrdology and assumptions used in developing the cost components are given below.

\section{A-4.1 Planning Studies and Tests}

Estimated costs for the planning studies and bench-scale tests for each facility consists of three subcomponents: manpower, test equipment, and equipment installation. Manpower is defined as the effort needed for initial paper studies, bench-scale tests, and secondary paper studies. Study durations and manpower estimates for these efforts were estimated when a given technology has not been previously used in the required application. The estimates are based on current status of the technologies as published in publicly available literature. Equipment budgetary costs and associated installation costs for lab equipment, such as mixers and prototype ovens used in tests, were estimated, as appropriate.

The planning studies and tests cost component was estimated assuming a cost of $\$ 150,000$ per full-time equivalent (FTE) for scientists and engineering manpower.

Table A-1 containing a development, testing, and evaluation cost estimating spreadsheet for a small sized vitrification facility is included as an example.

\section{A-4.2 Demonstration}

The demonstration cost component consists of nine subcomponents. Cost estimates for three of the subcomponents (manpower during demonstration, building structure, and equipment) were estimated as appropriate. The remaining six subcomponents (design, inspection, project administration, indirect, construction management, and contingency) were determined oy using percentage factors provided by EG\&G. These factors are the same as those used for the production facility (see Section A.4.3 below), and are as follows:

- Design, inspection, project administration, indirect, construction management, and contingency costs subcomponents are developed using percentage guidelines. This 
Table A-1. Development, testing, and evaluation cost estimates for vitrification facility.

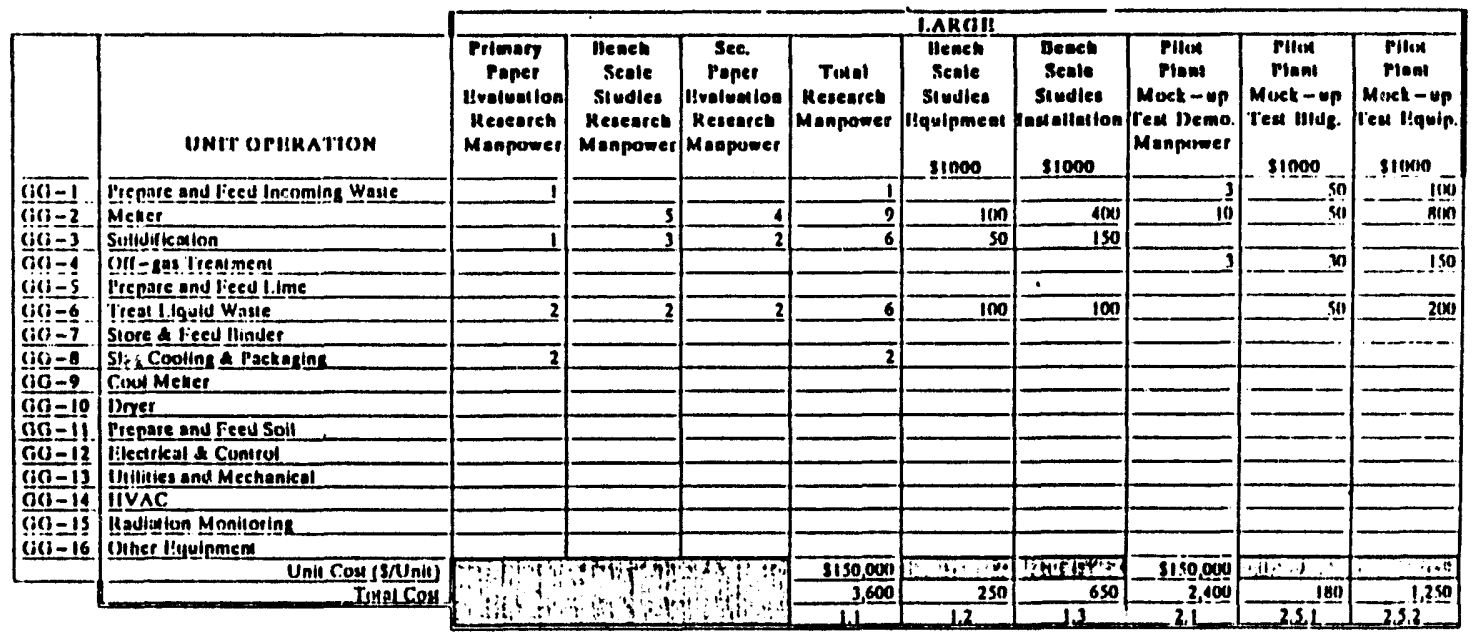


approach aids development of PLCC estimates suitable for relative comparison of various options. The percentages are historical averages experienced by DOE contractors at the INEL for the types of activities covered by waste management facilities. In addition:

- Contingency on all costs is $25 \%$.

- Design cost, applied to construction cost total, is $30 \%$ during the demonstration phase. Design cost during the production phase ranges from 6 to $18 \%$, depending on the complexity of the facility design.

- Inspection cost, applied to the construction cost total, ranges from 3 to $7 \%$.

- Project management cost, applied to the construction cost total, is $10 \%$.

- Indirect cost, applied to the total building plus equipment and installation costs, is $29 \%$.

- This assumes that the construction contractor will furnish all equipment and material. No Government Furnished Equipment is assumed.

- Construction management (CM) costs applied only to the production construction costs total, are $17.1 \%$.

- $\quad$ Construction management reserve is $10 \%$.

The demonstration equipment cost estimates are budgetary and based on industrial quality equipment, which costs less than the final nuclear quality equipment that will be provided for the production facility.

\section{A-4.3 Production Facility Construction}

The production facility construction cost consists of nine subcomponents. Three of the subcomponents, equipment, equipment installation, and building construction costs are estimated in this report and included in the cost model tables. The costs are based on an equipment list developed from the information provided in the F\&ORs and process functional diagrams. Equipment budgetary purchase costs are estimated using either vendor budgetary quotations, historical cost information, or engineering judgements. Equipment cost estimates are based on stainless steel material selected to allow ease of decontamination and maintenance. Installation costs are estimated for each piece of equipment and include labor, construction equipment, small tools, and supplies. Whenever vendor quotes were based on off-the-shelf equipment, they were multiplied by an appropriate adjustment factor to allow for NQA-1 and other more complex requirements of the specific process. Table A-2 containing equipment purchase and installation costs for a typical facility is included a an example. It should be noted that the total estimated purchased cost of a given equipment (cost in the column labeled as "Amount \$ x 1000's" under the "MTL. \& EQUIP." column) is obtained by multiplying the equipment cost adjustment factors $(A=3, B=2, C=2, D=1.2$ or $E=1)$ shown in the "FAC. CAT." column, times the equipment/material quantity shown in the "QTY" column, times the unit cost shown in the "Unit Cost $x \$ 1000$ 's" column. 
Table A-2. Equipment purchase and installation budgetary cost estimate for vitrification facility.

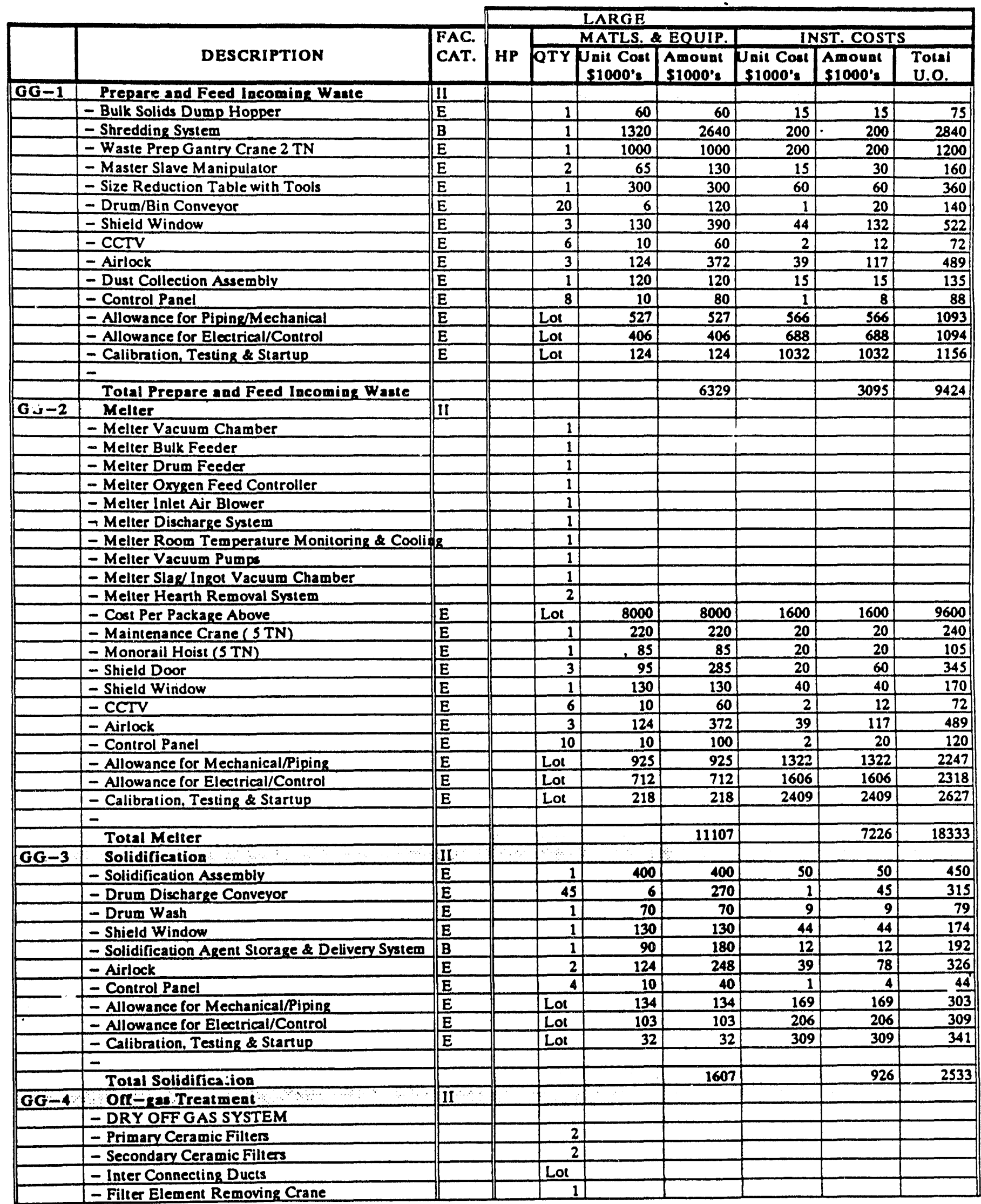


Table A-2. (continued).

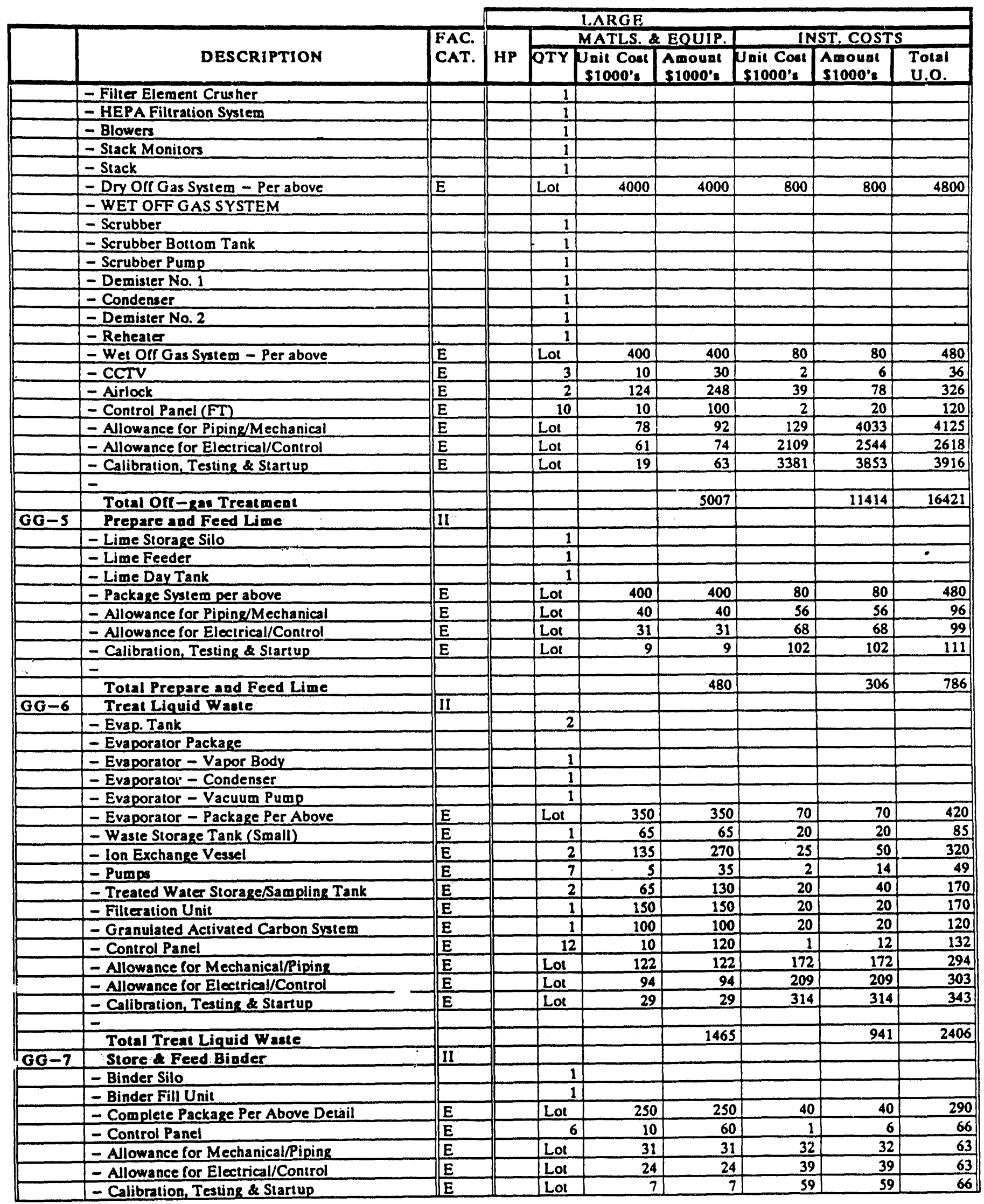


Table A-2. (continued).

\begin{tabular}{|c|c|c|c|c|c|c|c|c|c|}
\hline & & \multirow{3}{*}{$\begin{array}{l}\text { FAC. } \\
\text { CAT. }\end{array}$} & \multirow{2}{*}{\multicolumn{7}{|c|}{ I.ARGE }} \\
\hline & \multirow[b]{2}{*}{ DESCRIPTION } & & & & & & \multicolumn{3}{|c|}{ INST. COSTS } \\
\hline & & & HP & QTY & \begin{tabular}{|c|} 
Jait Cost \\
$51000^{\prime} s$
\end{tabular} & $\begin{array}{l}\text { Amount } \\
\text { S1000's }\end{array}$ & $\begin{array}{l}\text { Unit Cont } \\
\$ 1000^{\prime} s\end{array}$ & $\begin{array}{l}\text { Amount } \\
\$ 1000^{\prime} \mathrm{s}\end{array}$ & $\begin{array}{l}\text { Total } \\
\text { U.O. }\end{array}$ \\
\hline & - & & & & & & & & \\
\hline & Total Store \& Feed Binder & & & & & 372 & & 176 & 548 \\
\hline $\mathbf{G G - 8}$ & Slar Cooling \& Packaring & II & & & & & & & \\
\hline & - Metal Canister Capper & & & 1 & 150 & 150 & 30 & 30 & 180 \\
\hline & - Canister Decon Unit & $\mathrm{E}$ & & 1 & 70 & 70 & 9 & 9 & 79 \\
\hline & - Canister Cooling System & $E$ & & 2 & 200 & 400 & 40 & 80 & 480 \\
\hline & - Canisler Conveyor & $E$ & & 30 & 4 & 120 & 1 & 30 & 150 \\
\hline & - Airlock & $E$ & & 2 & 124 & 248 & 39 & 78 & 326 \\
\hline & - Shield Window & $E$ & & 2 & 130 & 260 & 44 & 88 & 348 \\
\hline & - Grouting Unil & $E$ & & 1 & 150 & 150 & 25 & 25 & 175 \\
\hline & - CCTV & $E$ & & 1 & 6 & 6 & 2 & 2 & 8 \\
\hline & - Control Panel - FT & E & & 8 & 10 & 80 & 1 & 8 & 88 \\
\hline & - Allowance for Mechanical/Piping & E & & Lot & 148 & 148 & 245 & 245 & 393 \\
\hline & - Allowance for Eloctrical/Con:rols & E & & Lol & 114 & 114 & 298 & 298 & 412 \\
\hline & - Calibration, Testing \& Startup & E & & Lot & 35 & 35 & 447 & 447 & 482 \\
\hline & - & & & & & & & & \\
\hline & Total Slas Cooling \& Packaging & & & & & 1781 & & 1340 & 3121 \\
\hline GG-9 & Cool Melter & II & & & & & & & \\
\hline & - Melier Cooling Water Unis. & & & 1 & & & & & \\
\hline & - Cooling Water Pump 150 GPM & & & 1 & & & & & \\
\hline & - Cooling Water Pump 200 GPM & & & 1 & & & & & \\
\hline & - Cooling Water Pump 2500 GAL & & & & & & & & \\
\hline & - Elevaled Water Tank & & & 1 & & & & & \\
\hline & - Cooling Tower & & & & & & & & \\
\hline & - Circulation pump & E & & & & & & & \\
\hline & - Complete Package per Above Delail & E & 100 & Lot & 300 & 300 & 704 & 70 & 370 \\
\hline & - Control Panel - FT & E & & 4 & 10 & 40 & 1 & 4 & 44 \\
\hline & - Allowance for Piping/Mechanical & E & & Lol & 34 & 34 & 52 & 52 & 86 \\
\hline & - Allowance for Electrical/Control & E & & Lol & 26 & 26 & 63 & 63 & 89 \\
\hline & - Calibration, Testing \& Starlup & $E$ & & Lol & 8 & 8 & 95 & 95 & 103 \\
\hline & - & & & & & & & & \\
\hline & Tolal Cool Meller & & & & & 408 & & 284 & 692 \\
\hline GG-10 & Dryer & II & & & & & & & \\
\hline & - Bulk Material Dryer & E & & 1 & 450 & 450 & 90 & 90 & 540 \\
\hline & - Dryer Conveyor & E & & 8 & 6 & 48 & 1 & 8 & 56 \\
\hline & - CCTV & E & & 2 & 10 & 20 & 2 & 4 & 24 \\
\hline & - Conirol Panel & $E$ & & 6 & 10 & 60 & 2 & 12 & 72 \\
\hline & - Allowance for Piping/Mechanical & E & & Lot & 58 & 58 & 80 & 80 & 138 \\
\hline & - Allowance for Electrical/Control & $E$ & & Lat & 45 & 45 & 97 & 97 & 142 \\
\hline & - Calibration, Testing \& Startup & E & & Lot & 14 & 14 & 146 & 146 & 160 \\
\hline & - & & & & & & & & \\
\hline & \begin{tabular}{|l} 
Total Dryer \\
\end{tabular} & & & & & 695 & & 437 & 1132 \\
\hline GG-11 & \begin{tabular}{|l} 
Prepare and Feed Soil \\
\end{tabular} & II & & & & & & & \\
\hline & - Melier Soil Feeder & E & & 1 & 400 & 400 & 80 & 80 & 480 \\
\hline & - Soil Day Tank & E & & 1 & 30 & 30 & 8 & 8 & 38 \\
\hline & - Soil Storage Silos & $\mathbf{E}$ & & 2 & 65 & 130 & 20 & 40 & 170 \\
\hline & - Soil Transfer Pump & $E$ & & 1 & 30 & 30 & 10 & 10 & 40 \\
\hline & - Control Panel & E & & 6 & 10 & 60 & 2 & 12 & 72 \\
\hline & - Allowance for Piping/M-rhanical & $E$ & & Lot & 65 & 65 & 105 & 105 & 170 \\
\hline & - Allowance for Eloctrical/Control & $E$ & & Lol & 50 & so & 128 & 128 & 178 \\
\hline & - Calibration, Testing \& Startup & $E$ & & Lor & 15 & 15 & 192 & 192 & 207 \\
\hline & - & & & & & & & & \\
\hline & Total Prepare and Feed Soil & & & & & 780 & & 575 & 1355 \\
\hline GG-12 & Electrical \& Confrol & III & & & & & & & \\
\hline & - Control Panel - FT & $E$ & 170 & 25 & 10 & 250 & 2 & 30 & 300 \\
\hline & - Motor Control Center & E & & 75 & 6 & 450 & 1 & 75 & 525 \\
\hline & - Sland by Emergency Power & $E$ & & 1 & 230 & 230 & 80 & 80 & 310 \\
\hline & - Allowance for Mechanical/ Piping & $E$ & & Lot & 93 & & 144 & & \\
\hline & - Allowance for Eloctrical/Control & $E$ & & Lot & 65 & 65 & 103 & 103 & 168 \\
\hline & - Calibration Test \& Startup & $\sqrt[E]{E}$ & & Lot & 20 & 20 & 154 & 154 & 174 \\
\hline
\end{tabular}


Tab'e A-2. (continued).

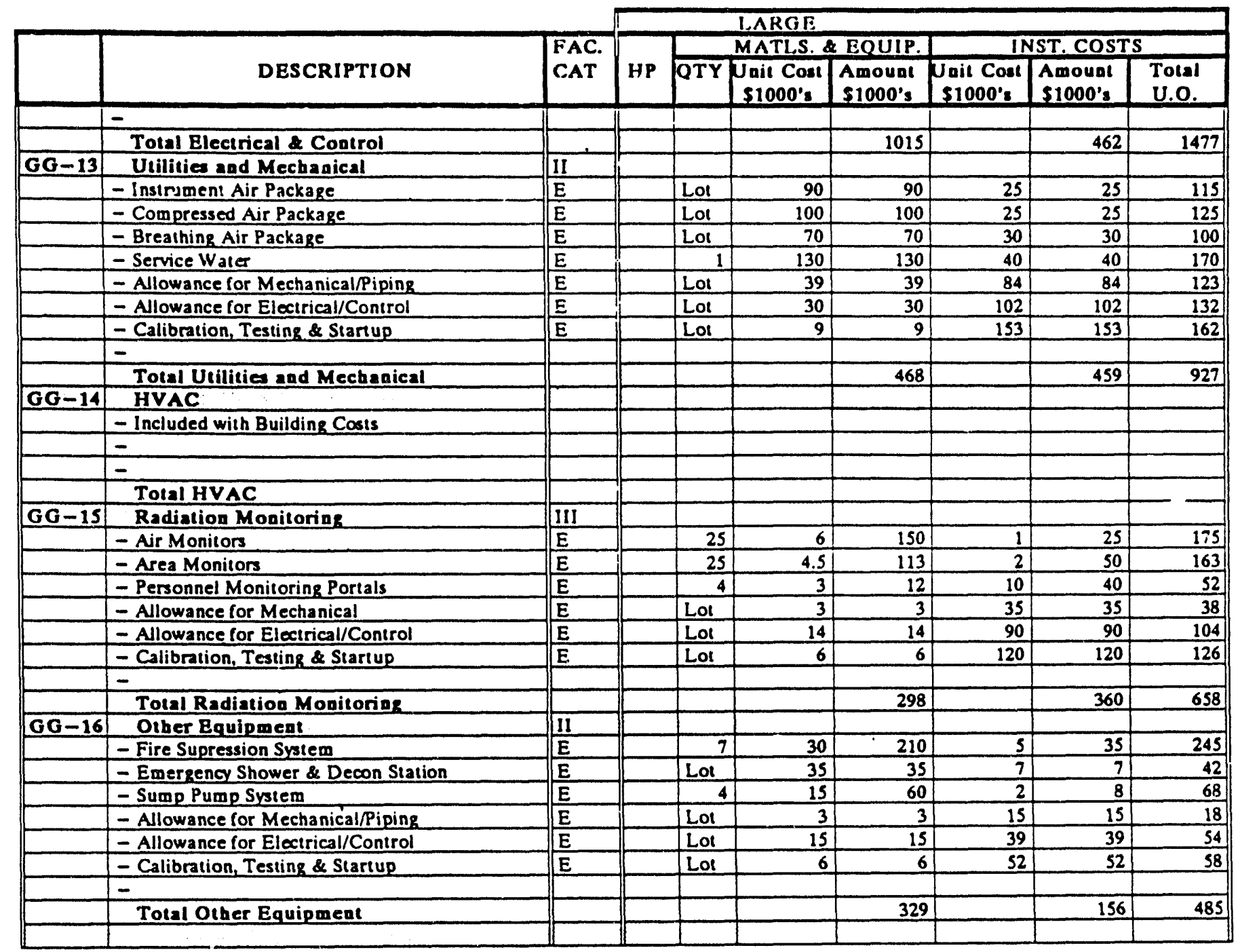


A third subcomponent, building cost, is developed by two different methods:

- Building cost estimates for complex structures are developed by generating material list and quantities from the layout sketches, estimating the required construction labor hours, and multiplying the material quantities and labor hours by the appropriate unit rates. The cost estimates are compiled according to various cost categories is the building. The total of each cost categories is divided by the number of square footage building in that category to obtain a specific cost unit rate per square foot.

- For standard structures (e.g., nonprocess area and office space), the building cost estimate is obtained by multiplying the estimated building space for each unit operation by a set of standard unit rates provided by EG\&G Idaho and MK as follows:

- Low hazard areas: Low hazards areas (e.g., areas for support and nonprocess functions including office) are $\$ 180 / \mathrm{ft}^{2}$.

- Moderate hazard areas: Moderate hazard building space including areas used for chemical storage, laboratories is $\$ 420 / \mathrm{ft}^{2}$.

A list of the facility-specific building unit ates is presented in Table A-3. The building cost estimate is obtained by multiplying the above unit rates by the estimated building space required for each unit operation. The allocated building space estimates are developed from the scoping study layout sketches. The estimates include allocated space in separate categories to account for different cost categories. The estimated square footage and the calculated building cost estimates for each unit operation are listed in the cost model tables. Table A-4 containing building and equipment material and installation estimate cost summary for a typical facility is included as an example.

The building unit rates costs are representative of the building and its support systems, including utilities, fire protection, and site development costs. The process and storage building costs include high-efficiency particulate air (HEPA) filter systems. Special equipment and any additional mechanical or electrical systems necessary for operation of the equipment have not been included in the building unit rate costs. The unit rates do not include the construction contractor direct and indirect costs (e.g., overheads and profit).

The remaining six cost subcomponents (design, inspection, project administration, indirect, construction management, and contingency) are determined using percentage factors. These percentages, the building unit rates, and other major assumptions used to develop the production facility construction costs are the same as listed in Section A-4.2.

Facility construction cost estimates in this report do not include the infrastructure (utilities, roads or site development) beyond the TSD facility walls.

\section{A-4.4 Operatior, and Maintenance}

Operation and maintenance (O\&M) cost comprises four subcomponents: operating manpower, utilities, materials, and maintenance. Operating manpower is estimated for each unit operation by assuming an appropriate operating crew for that unit. The estimated operating FTE requirements for each unit operation is presented in tables in the main sections of this report. PLCC estimates for the utility cost subcomponents, summarized in the cost model tables, include electric power, 
Table A-3. Facility-specific building unit rate costs.

\begin{tabular}{|c|c|c|c|c|}
\hline & SNF Module & & Cost Category & Unit Rate \\
\hline \multirow[t]{2}{*}{1.} & Administration & 1) & Office area & $\$ 180 / \mathrm{ft}^{2}$ \\
\hline & & 2) & Laboratory area & $\$ 420 / \mathrm{ft}^{2}$ \\
\hline \multirow[t]{4}{*}{2.} & $\begin{array}{l}\text { Receiving Preparation } \\
\text { and Shipping Facility }\end{array}$ & 1) & $\begin{array}{l}\text { Access control, and } \\
\text { nonradioactive area }\end{array}$ & $\$ 180 / \mathrm{ft}^{2}$ \\
\hline & & 2) & $\begin{array}{l}\text { Radioactive processing } \\
\text { equipment areas-non } \\
\text { alpha cells }\end{array}$ & $\$ 420 / \mathrm{ft}^{2}$ \\
\hline & & 3) & $\begin{array}{l}\text { GTCC cask } \\
\text { staging/handling bay and } \\
\text { operating areas next to } \\
\text { shielded process cells }\end{array}$ & $\$ 800 / \mathrm{ft}^{2}$ \\
\hline & & 4) & $\begin{array}{l}\text { Hot cell areas for } \\
\text { process equipment }\end{array}$ & $\$ 2,100 / \mathrm{ft}^{2}$ \\
\hline \multirow[t]{4}{*}{3.} & Treatment Facilities & 1) & $\begin{array}{l}\text { Access control, } \\
\text { nonradioactive area }\end{array}$ & $\$ 180 / \mathrm{ft}^{2}$ \\
\hline & & 2) & $\begin{array}{l}\text { Radioactive processing } \\
\text { equipment areas - } \\
\text { nonalpha cell }\end{array}$ & $\$ 420 / \mathrm{ft}^{2}$ \\
\hline & & 3) & $\begin{array}{l}\text { Operating areas next to } \\
\text { shield cubicles }\end{array}$ & $\$ 800 / \mathrm{ft}^{2}$ \\
\hline & & 4) & $\begin{array}{l}\text { Hot cell areas for } \\
\text { process equipment }\end{array}$ & $\$ 2,100 / \mathrm{ft}^{2}$ \\
\hline \multirow[t]{2}{*}{4.} & $\begin{array}{l}\text { Silo Storage (cost } \\
\text { module MM) }\end{array}$ & 1) & $\begin{array}{l}\text { Cost of each } \\
\text { prefabricated silos }\end{array}$ & \$17,000/ea. \\
\hline & & 2) & Cost of storage yard & $\$ 41 / \mathrm{ft}^{2}$ \\
\hline
\end{tabular}


Table A-3. (cuntinued).

\section{SNF Module}

Cost Category

Unit Rate

5. Enclosed Vault Storage (cost module Z)

1) Access control area

$\$ 180 / \mathrm{ft}^{2}$

2) Storage \& monitoring

$\$ 260 / \mathrm{ft}^{2}$

other than storage vaults

3) Assay/inspect and drum

$\$ 1,000 / \mathrm{ft}^{2}$

transfer cubicle

4) Storage vaults

$\$ 530 / \mathrm{ft}^{2}$

6. Intermediate Depth

Disposal (cost module

KK)

1) Surface structures access
control, truck bay and

$250 / \mathrm{ft}^{2}$

radioactive storage areas

2) Air exhaust shaft

$1,000 / \mathrm{ft}^{\mathrm{a}}$

3) Disposal drift drill \&

$\$ 4,100 / \mathrm{ft}^{\mathrm{a}}$ blast

$\$ 8,900 / f t$

4) Main access

shaft/operating gallery

7. Disposal Front-End

Support Facility (cost

1) Cost Category $1^{\mathrm{c}}$

$\$ 165 / \mathrm{ft}^{2}$

module $\mathrm{O}^{\mathrm{b}}$

2) Cost Category $2^{d}$

$231 / \mathrm{ft}^{2}$

3) Cost Category $3^{e}$

$346 / \mathrm{ft}^{2}$

\section{Notes:}

a. Cost is valid for a shaft approximately $300 \mathrm{ft}$. deep

b. Based on similar facilities at the Illinois LLW site.

c. Space for administration/offices, warehouse and maintenance, material storage for grout plant, unload/staging area, storage building, canister storage at the waste packaging building, utilities/mechanical building, and electrical substation.

d. Space for site access building and truck wash station, as well as the lab.

e. Space for waste packaging area, grout plant, assay, inspection, certification, secondary treatment, and waste packaging. 
Table A-4. Building and equipment material and installation cost estimate summary for vitritication facility.

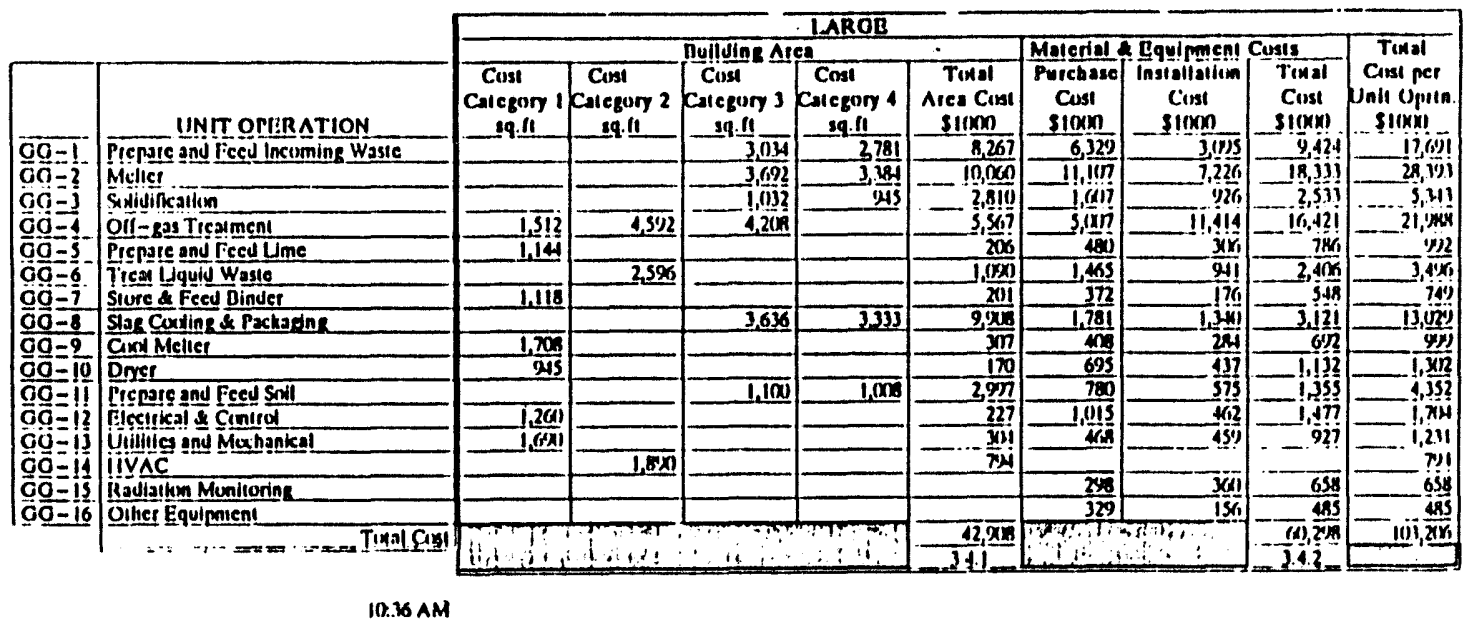


natural gas or No. 2 fuel oil, as appropriate. These costs are estimated by multiplving the equipment horsepower and energy consumption rates for each facility by the given energy cost unit rates (see below).

The material cost subcomponents includes consumables such as shipping/disposal containers, additives, chemicals, drums, boxes, bags, and personal protective equipment. These are estimated for each facility based on the process flow rates given in the preconceptual design packages and are listed in the tables included in the cost model.

The maintenance cost subcomponent is divided into maintenance labor and maintenance replacement equipment cost. These costs, presented in the tables in the cost model, are obtained by assuming that the annual maintenance equipment cost is $7 \%$ of the original equipment capital cost and that the annual maintenance labor cost is $250 \%$ of the maintenance equipment cost. Table A-5 containing annual operating and maintenance cost estimate for a typical facility is included as an example.

General assumptions used to develop the operation and maintenance costs are given below:

- The following utility ind operating rates are established based on INEL site for the development of life cycle costs:

- Electricity@ @ \$0.035/Kwh.

- Propane @ \$0.60/gal.

- $\quad$ No. 2 fuel oil @ $\$ 0.80$ per gallon.

- Present day costs are used for preparation of the O\&M cost estimates.

- A contingency factor of $25 \%$ is applied to the project subtotal O\&M costs.

- Operating staff labor rate is $\$ 140,000 / F T E$.

- The O\&M costs are based on a facility operating schedule of three 8-hour shifts, 5 days/week, and 240 days/year.

- Portland cement binder cost for solidification is $\$ 0.05 / \mathrm{lb}$.

- Shipping/disposal container is 55-gal. drums at \$25/each.

\section{A-4.5 Operating Budget Funded Activities}

In accordance with DOE orde.s, a number of activities cannot be charged to the Line Item Construction Projects (LICP) funds. A breakdown of these activities and preliminary cost estimates are given below. It is assumed that the level of effort required for some of these activities are the same for all major facilities, except for the administration support facilities. 
Table A-5. Annual operating and maintenance cost estimates for vitrification facility.

\begin{tabular}{|c|c|c|c|c|c|c|c|}
\hline \multirow[b]{2}{*}{ 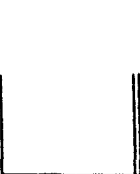 } & \multirow[b]{2}{*}{ UNTT OPERATION } & \multicolumn{6}{|c|}{ LARGE } \\
\hline & & $\begin{array}{c}\text { Operating } \\
\text { FTE }\end{array}$ & $\begin{array}{c}\text { Utilities } \\
\$ 1000 \\
\end{array}$ & $\begin{array}{c}\text { Materials } \\
\mathbf{5 1 0 0 0}\end{array}$ & $\begin{array}{c}\text { Maintenance } \\
\text { Labor (1) } \\
51000\end{array}$ & $\begin{array}{c}\text { Maiatenance } \\
\text { Materials (2) } \\
51000 \\
\end{array}$ & $\begin{array}{l}\text { Totals } \\
\$ 1000 \\
\end{array}$ \\
\hline GG-1 & Prepare and Feed Incoming Waste & 2 & 10 & 4 & 1,108 & 443 & 1551 \\
\hline GG-2 & Melter & 4 & 90 & & 1,943 & 777 & 2,720 \\
\hline $\mathrm{GG}-3$ & Solidification & 2 & 5 & 30 & 280 & 112 & 392 \\
\hline $\mathrm{GG}-4$ & Off-gas Treatment & 2 & 12 & 360 & 875 & 350 & 1225 \\
\hline GG-5 & Prepare and Feed Lime & 2 & 1 & 15 & 85 & 34 & 119 \\
\hline $\mathrm{GG}-6$ & Treat Liquid Waste & 2 & 3 & 8 & 258 & 103 & 361 \\
\hline $\mathrm{GG}-7$ & \begin{tabular}{|l} 
Store \& Feed Binder \\
\end{tabular} & 2 & 6 & & 65 & 26 & 91 \\
\hline GG-8 & Slag Cooling \& Packaging & 2 & 3 & & 313 & 125 & 438 \\
\hline GG-9 & Cool Melter & 1 & 14 & & 73 & 29 & 102 \\
\hline GG-10 & Dryer & 4 & & & 123 & 49 & 172 \\
\hline GG-11 & Prepare and Feed Soil & 2 & 2 & & 138 & 55 & 193 \\
\hline GG-12 & Electrical \& Control & 2 & 2 & & 178 & 71 & 249 \\
\hline $\mathrm{GG}-13$ & Utilities and Mechanical & 2 & & & 83 & 33 & 116 \\
\hline $\mathrm{GG}-14$ & HVAC & 2 & 52 & & & & \\
\hline GG-15 & Radiation Monitoring & 1 & 2 & & 53 & 21 & 74 \\
\hline \multirow[t]{4}{*}{ GG-16 } & Other Equipment & 4 & & & 58 & 23 & 81 \\
\hline & Unit cost (S/unit) & $\$ 140,000$ & & & & & \\
\hline & \begin{tabular}{|c|} 
Total Cost \\
\end{tabular} & 5,040 & 202 & 417 & & & 7,884 \\
\hline & Post Totals To Table 8-6, Item & 5.1 & 5.2 & 5.3 & & & 5.4 \\
\hline
\end{tabular}

Notes:

1. Annual Maintenance Labor is $250 \%$ of maintainence material cost.

2. Maintenance Material is assumed to be $7 \%$ of equipment capital cost. 
Project activities to be funded by operating budgets and the estimated costs are

- Conceptual design at $1.5 \%$ of construction cost.

- Project management before Title I design at $10 \%$ of the costs for NEPA conceptual design safety assurance and preparation for operation.

- Environmental and permitting (NEPA documentation including environmental impact statements, federal, state, and local permits) estimated at six million dollars $(\$ 6,000,000)$ for each waste treatment and disposal facility that requires a full NEPA process including preparation, review and approval of an environmental impact statement (EIS). Smaller projects are assumed to require only an environmental assessment (EA) report followed by a finding of no significant impact (FONSI) and are estimated at one million dollars $(\$ 1,000,000)$. Since front-end and back-end support facilities are assumed to be constructed along with the main facilities, no permitting/NEPA cost allowances are required.

- Safety assurance documentation (safety analysis, reliability, availability and maintainability analysis, probabilistic risk assessment, hazards analysis, criticality reviews, and radiation analysis) at $1.5 \%$ of the construction cost.

- Preparation for operation (operations procedure, operating personnel staffing, training and testing, readiness reviews, spare parts, and material) is assumed to start three years before the facility begins production operation. Based on the experience at the TSCA incinerator at Oak Ridge National Laboratory (ORNL), the cost for the preoperation activity is assumed to be approximately $100 \%$ of the annual operating cost. This accounts for $15 \%$ for the first year of preoperation, $25 \%$ in the second year, and $60 \%$ in the last year.

\section{A-4.6 Decommissioning}

Decontamination and decommissioning costs for treatment facilities are based on a recent cost study conducted by EG\&G Idaho for the buried TRU waste (Schlueter 1992). Based on this study, a cost of $\$ 450 / \mathrm{ft}^{3}$ average unit rate for treatment facilities is used. Table A-6 containing decontamination and decommissioning costs for a typical facility is included as an example.

\section{A-4.7 Transportation Costs}

Transportation costs are estimated based on budgetary quotes submitted by vendors. The estimated unit rates and the basis are presented in Section 18.5.6 of this report.

\section{A-4.8 Cost Summaries}

Cost summaries are presented according to the six components described in this appendix. Also shown in cost summary tables are cost subcomponents and the appropriate multiplication factors. These tables have been included in Sections 2 through 9 of this report. 
Table A-6. Decontamination and decommissioning cost estimates for vitrification facility.

\begin{tabular}{|c|c|c|c|c|c|c|}
\hline & \multirow[b]{4}{*}{ UNTT OPERATION } & \multicolumn{5}{|c|}{ LARGE } \\
\hline & & \multicolumn{4}{|c|}{ Building Area } & \multirow{3}{*}{$\begin{array}{c}\text { Total } \\
\text { Area Cost }\end{array}$} \\
\hline & & $\begin{array}{l}\text { Cost } \\
\text { Category } 1\end{array}$ & $\begin{array}{c}\text { Cost } \\
\text { Category } 2\end{array}$ & \begin{tabular}{|c|} 
Cost \\
Category 3
\end{tabular} & \begin{tabular}{|l} 
Cost \\
Category 4
\end{tabular} & \\
\hline & & & & & & \\
\hline & 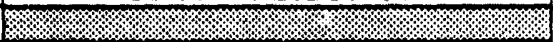 & min & $29 \pi$ & $3 n !$ & 30.96 & \% Ton: \\
\hline GG-1 & Prepare and Feed Incoming Waste & & & 3,034 & 2,781 & 2,617 \\
\hline$G G-2$ & Melter & & & 3,692 & 3,384 & 3,184 \\
\hline GG-3 & Solidification & & & 1,032 & 945 & 890 \\
\hline GG-4 & Off-gas Treatment & 1,512 & 4,592 & 4,208 & & 4,640 \\
\hline GG-5 & Prepare and Feed Lime & 1,144 & & & & 515 \\
\hline GG-6 & Treat Liquid Waste & & 2,596 & & & 1,168 \\
\hline GG-7 & Store \& Feed Binder & 1,118 & & & & 503 \\
\hline GG-8 & Slag Cooling \& Packaging & & & 3,636 & 3,333 & 3,136 \\
\hline$G G-9$ & Conl Melter & 1,708 & & & & 769 \\
\hline$G G-10$ & Dryer & 945 & & & & 425 \\
\hline GG-11 & Prepare and Feed Soil & & & 1,100 & 1,008 & 949 \\
\hline$G G-12$ & Electrical \& Control & 1260 & & & & 567 \\
\hline$G G-13$ & Utilities and Mechanical & 1,690 & & & & 761 \\
\hline$G G-14$ & HVAC & & 1,890 & & & 851 \\
\hline$G G-15$ & Radiation Monitoring & & & & & \\
\hline $\mathrm{GG}-16$ & Other Equipment & & & & & \\
\hline & $\frac{\text { Total Cost }}{10: 33 \mathrm{M}}$ & & & & & $\frac{20,975}{6.0}$ \\
\hline
\end{tabular}



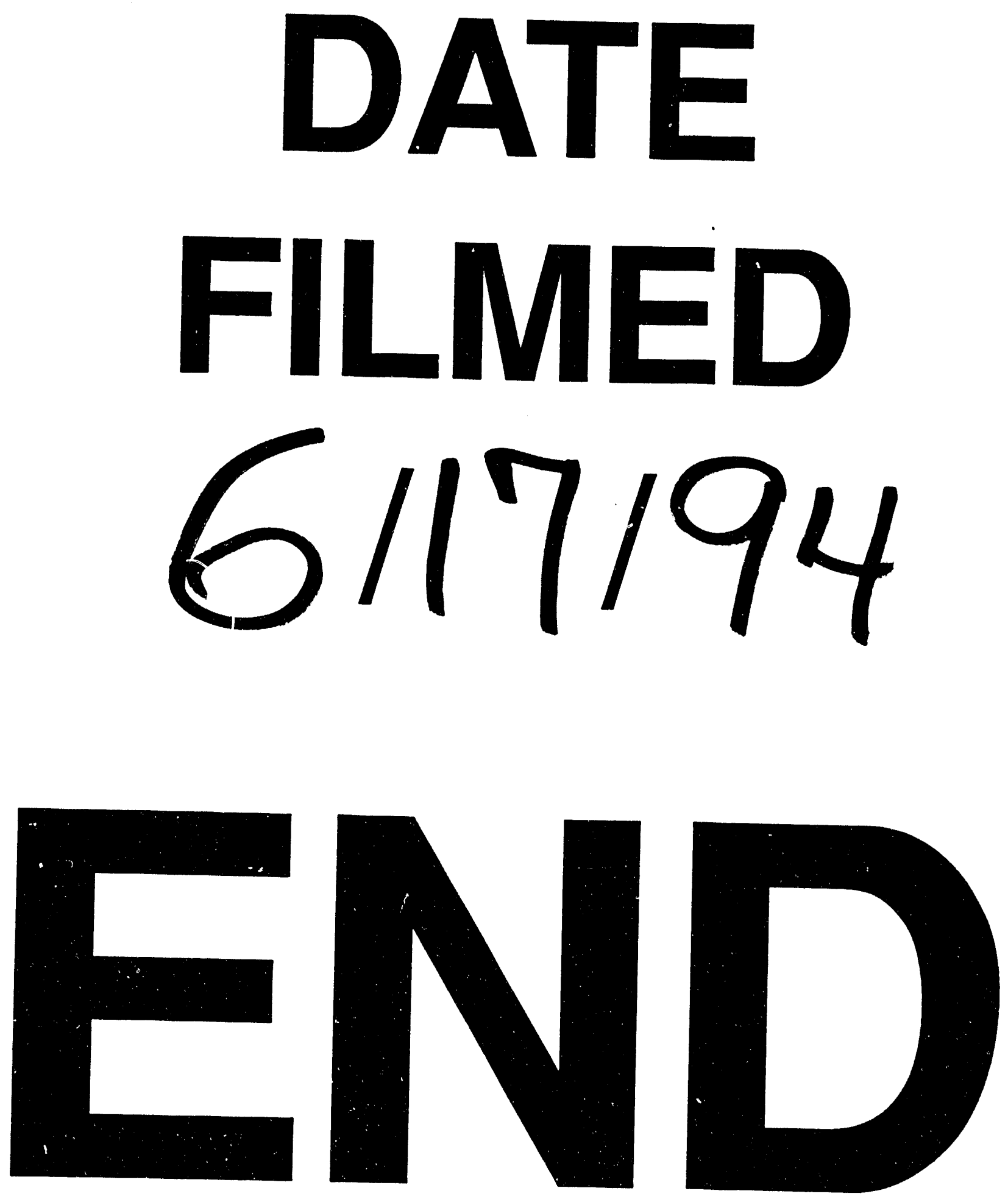
